\title{
Techniques to improve visual performance following corneal surgery
}

Citation for published version (APA):

Eggink, G. J. (2001). Techniques to improve visual performance following corneal surgery. [Doctoral Thesis, Maastricht University]. Universiteit Maastricht. https://doi.org/10.26481/dis.20011129ge

Document status and date:

Published: 01/01/2001

DOI:

10.26481/dis.20011129ge

Document Version:

Publisher's PDF, also known as Version of record

\section{Please check the document version of this publication:}

- A submitted manuscript is the version of the article upon submission and before peer-review. There can be important differences between the submitted version and the official published version of record.

People interested in the research are advised to contact the author for the final version of the publication, or visit the DOI to the publisher's website.

- The final author version and the galley proof are versions of the publication after peer review.

- The final published version features the final layout of the paper including the volume, issue and page numbers.

Link to publication

\footnotetext{
General rights rights.

- You may freely distribute the URL identifying the publication in the public portal. please follow below link for the End User Agreement:

www.umlib.nl/taverne-license

Take down policy

If you believe that this document breaches copyright please contact us at:

repository@maastrichtuniversity.nl

providing details and we will investigate your claim.
}

Copyright and moral rights for the publications made accessible in the public portal are retained by the authors and/or other copyright owners and it is a condition of accessing publications that users recognise and abide by the legal requirements associated with these

- Users may download and print one copy of any publication from the public portal for the purpose of private study or research.

- You may not further distribute the material or use it for any profit-making activity or commercial gain

If the publication is distributed under the terms of Article $25 \mathrm{fa}$ of the Dutch Copyright Act, indicated by the "Taverne" license above, 


\section{Techniques to improve visual performance following corneal surgery}

\section{PROEFSCHRIFT}

ter verkrijging van de graad van doctor aan de Universiteit Maastricht, op gezag van de Rector Magnificus, Professor dr A.C. Nieuwenhuijzen Kruseman volgens besluit van het College van Decanen, in het openbaar te verdedigen op donderdag 29 november 2001 om 16.00 uur

door

Ferdinand Antonius Gerardus Johannes Eggink geboren op 29 maart 1948

te 's-Gravenhage 
Promotor:

Co-promotores:
Prof. dr. F. Hendrikse

Dr. R.M.M.A. Nuijts

Dr. G.R.J. Melles (Netherlands Institute for Innovative Ocular Surgery)

Beoordelingscommissie: Prof. dr. ir. L.H. Koole (voorzitter)

Prof. dr. A.F. Deutman (Katholieke Universiteit Nijmegen)

Prof. dr. ir. A.P.G. Hoeks

Prof. dr. G. van Rij (Erasmus Universiteit Rotterdam)

Dr C.A.B. Webers 


\section{CONTENTS}

Chapter 1 General introduction and aim of the study 9

1.1 General introduction 10

1.2 Aims of the study 11

1.3 References 12

$\begin{array}{ll}\text { Chapter } 2 \text { Review of the literature } & 13\end{array}$

2.1 Refractive anomaly 14

2.2 Rigid comeal contact lens fitting 18

2.3 Corneal topograplyy 24

2.4 Corneal keratoplasty surgery 32

2.5 Corneal excimer laser surgery 44

2.6 References 65

Chapter 3 A new technique for rigid gas permeable contact lens fitting following penetrating keratoplasty

Acta Ophthalmologica Scandinavica 2001;79:245-50

Chapter $4 \mathrm{~A}$ new technique for rigid gas permeable contact lens fitting following deep anterior lamellar keratoplasty

(Submitted for publication)

Chapter 5 Granular dystrophy of the cornea. Contact lens fitting after phototherapeutic keratectomy

Cornea 1995;14:217-222

Chapter 6 Recovery of the visual acuity in a family with Reis-Bückler dystrophy

(Submitted for publication)

Chapter 7 Enlargement of the photorefractive keratectomy optical zone

J Cataract Refract Surg 1996;22:1159-64 
Chapter 8 Postoperative management and follow up after corneal flap loss following

laser in situ keratomileusis

(Accepted by J Cataract Refract Surg)

Chapter 9 Contact lens fitting in a patient with keratectasia after laser in situ keratomileusis.

J Cataract Refract Surg 2001;27:1119-23

Chapter 10 Rigid gas permeable contact lens fitting in laser in situ keratomileusis patients for the correction of multifocal corneas

Graefe's Arch Clinical Exp Ophthal 2001;239:361-6

Chapter 11 General discussion

Chapter 12 Summary / Samenvatting

187

12.1 Summary

12.2 Samenvatting

List of abbreviations

List of publications

Dankwoord

Curriculum vitae

Colofon 
CHAPTER 1

General introduction and aim of the study 


\section{Chapter 1}

\subsection{GENERAL INTRODUCTION}

Corneal surgery is currently going through a Renaissance for both corneal keratoplasty and corneal refractive laser surgery. ${ }^{1,2}$ The introduction of corneal excimer laser surgery and new keratoplasty surgical techniques like deep anterior lamellar keratoplasty and posterior lamellar keratoplasty have broadened the array of treatments for corneal disorders and may be used as alternatives for penetrating keratoplasty. ${ }^{3,4}$ Nevertheless, in all these techniques, optical effects like postoperative ametropia and/or irregular astigmatism may occur and present major obstacles for successful visual rehabilitation. ${ }^{5}$

Therefore, the fitting of rigid contact lenses remains one of the cornerstones of visual restoration after corneal (laser) surgery. Significant progress in the development of new contact lens materials and designs contribute to a higher success rate of post-keratoplasty contact lens fitting.

Corneal excimer laser surgery is primarily used for the correction of myopia. It was estimated that in the United States in the year 2000, two million eyes underwent corneal refractive surgery. The overwhelming majority of these patients were treated with laser in situ keratomileusis (LASIK), a technique introduced by Pallikaris and coauthors in 1990. ${ }^{6.7}$

In general, the results of LASIK are satisfying with respect to predictability, safety and efficacy, yet major side effects in night vision are still reported. According to some authors the incidence of glare and halo's in dim light conditions may be as high as $30 \% .{ }^{8}$ Causes for night vision problems include decentration of the ablation zone, irregular wound healing induction of corneal aberrations and scotopic pupil size vs. treatment zone disparity."

With the introduction of the microkeratome, flap related intraoperativeand postoperative complications were introduced that may also lead to irregular astigmatism. Surgical correction of these side effects using topographically guided ablations have been used with limited success. Certainly in some of these cases specially designed rigid contact lenses may play a role in the correction of these adverse effects.

Excimer laser phototherapeutic keratectomy (PTK) is a technique used for correction of microscopic irregularities of the corneal surface and subepithelial opacities. In diseases like anterior basement membrane dystrophies and anterior stromal dystrophies laser ablation surgery may effectively remove the irregularities and opacities. Following PTK, we demonstrated that rigid gas permeable contact lens fitting was not able to improve visual acuity.

Knowledge of the opportunities that rigid gas permeable contact lenses provide for increasing visual performance after keratoplasty and corneal refractive surgery techniques is useful for ophthalmologists confronted with these categories of patients. 


\subsection{AIMS OF THE STUDY.}

Aim of the study is to determine the safety and efficacy of various contact lens fitting techniques and to define at what postoperative time interval, what type of complication after corneal surgery can be effectively managed with rigid contact lens fitting. (hapter 3: Evaluation of the safety and efficacy of a new contact lens fitting technique in patients following penetrating keratoplasty. Chapier 4: Evaluation of the safety and efficacy of a new contact lens fitting teclnique in patients after lamellar keratoplasty. Chapter 5: Evaluation of the efficacy of a contact lens fitting technique in a patient with granular dystrophy, after PTK treatment. Chapter 6: Evaluation of the visual acuity with and without contact lens wear in a family with a Reis Bückler dystrophy after PTK treatment. (.hapter 7: Study of the efficacy of an enlargement of the photorefractive keratectomy ablated $5.0 \mathrm{~mm}$ zone diameter to $6.0 \mathrm{~mm}$ in combination with treatment of the undercorrections. ('hapter 8: Visual acuity recovery, with and without contact lenses in LASIK patients after Flap loss. Chapter 9: Contact lens fitting technique to correct the optical distortion of cornea ectasia which developed in a LASIK patient more than one year following LASIK treatment. (hapier 10: Evaluation of the efficacy of rigid gas permeable contact lens fitting technique used in eyes with multifocal LASIK ablations to correct halo's and impaired night vision complaints. 


\section{Chapter 1}

\subsection{REFERENCES}

\footnotetext{
${ }^{1}$ Melles GRJ, Remeijer L, Geerards AJM, Beekhuis WH. The future of lamellar keratoplasty. Current Opinion in Ophthalmol 1999;10:253-9

2 American Academy of Ophthalmology. Excimer laser photorefractive keratectomy (PRK) for myopia and astigmatism.Ophthalmology 1999;106:422-37.

${ }^{3}$ Brady SE, Rapuano CJ, Arentsen JJ, et al. Clinical indications for and procedures associated with penetrating keratoplsty, 1983-1988. Am J Ophthalmol 1989;108: 118

${ }^{4}$ Meier U, Anastasi C, Failla F, Simona F. Die Möglichkeiten der therapeutischen

Photokeratektomie mit dem Excimerlaser bei der Behandlung der Schnijder kristalinen

Hornhautdystrophie. Klin Monatsbl Augenheilkd 1998;212:405-6

${ }^{5}$ Waring GO III, ed. Refractive Keratotomy for Myopia and Astigmatism. St. Lois, MO

Mosby Year Book; 1992:1157

"Pallikaris IG, Papatzanaki ME, Stathi EZ, et al. Laser in situ keratomileusis. Lasers Surg Med 1990;10:436-468

'Pallikaris IG, Siganos DS. Excimer laser in situ keratomileusis and photorefractive keratectomy for correction of high myopia. J Refract Corneal Surg 1994;10:498-510

${ }^{8}$ Knorz MC, Jendritza B, Hugger P, Liermann A. Komplikationen der laser in situ keratomileusis (LASIK). Der Ophthalmologe 1999,96:503-8

"Holladay JT, Dudeja DR, Chang J. Functional vision and corneal changes after laser in situ keratomileusis determined by contrast sensitivity, glare testing, and corneal topography. J

Cataract Refract Surg 1999;25:663-9
} 
CHAPTER 2

Review of the literature 


\subsection{REFRACTIVE ANOMALY}

A ray of light entering the eye is refracted by the cornea, passes through the anterior chamber, is refracted by the lens, and comes to a focus. The location of this focus is determined by the combined refractive power of the cornea, the lens, and the media surrounding them. The length of the eye determines whether the focus is in front of the retina as in myopia, upon the retina as in emmetropia, or whether the retina intercepts converging rays before they reach a focus as in hyperopia

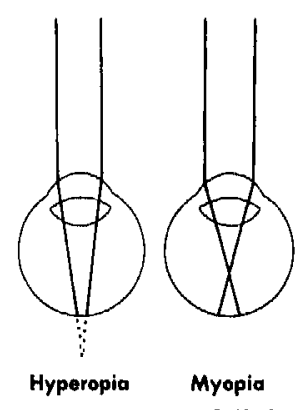

Figure 2-1. A ray of light refracted by a hyperopic and myopic eye.(figure: Geertjan van Zonneveld)

The diopter, the unit of measurement in optics, is equal to the reciprocal of the focal length of a lens in meters. The cornea has a focal distance of 0,0233 meters and its refractive power is $1 / 0.0233$ or 43 diopters. ${ }^{1}$

The total refractive power of the eye is about 58 diopters (D). The axial length of the globe varies from 20 to $29 \mathrm{~mm}$, with a mean of $23.5 \mathrm{~mm}$.

Refractive errors arise from a disparity between the refractive power of the anterior segment and the length of the globe, called ametropia.

Emmetropia is the optical condition in which parallel rays of light come to a focus on the fovea centralis. Astigmatism is the optical condition in which the refracting power of the eye is not the same in all meridians: if the refracting power of the eye is 58 diopters in the vertical and 60 diopters in the horizontal meridian, two diopters of astigmatism are present. ${ }^{2}$ Parallel rays of light do not focus at a point but there are two focal lines, one corresponding to the 60 diopter meridian and another corresponding to the 58 diopter meridian. ${ }^{3}$ The distance separating these focal lines is the conoid of Sturm. If there are but two focal lines, the condition is regular astigmatism ${ }^{4}$; if more than two, irregular astigmatism. ${ }^{5}$

Astigmatism may be myopic, with both focal lines in front of the retina, hyperopic, with both focal lines intercepted by the retina before reaching a 
focus, or mixed, in which one focal line would focus in front of the retina, and the other focal line would have a focus behind the retina. ${ }^{6}$

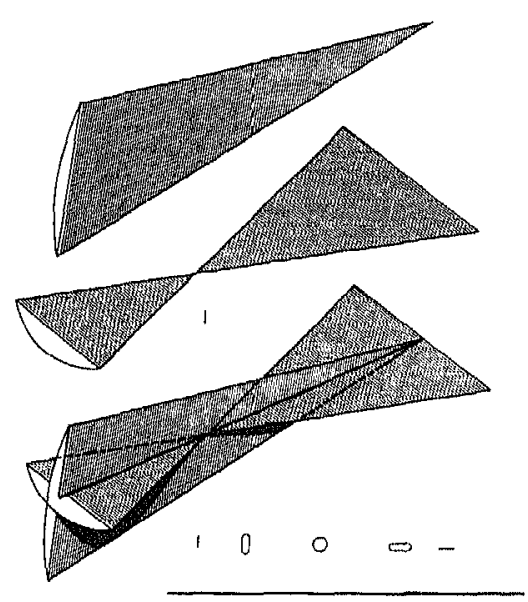

Fig 2-2. The refraction by cylindrical lenses. A cylindrical lens has its refractive power in the meridian opposite the meridian designated as axis. Parallel rays of light come to a linear focus and not a point focus. When cylindrical lenses of unequal power are combined they form two major focal lines corresponding to their refractive power. The distance between the two focal lines is the conoid of Sturm. A circle of least confusion is located between the focal lines at an area where the diverging and converging tendency of the rays are the same.(Figure: Geertjan van Zonneveld)

Astigmatism usually occurs because of a difference in curvature of the vertical and horizontal meridians of the cornea. ${ }^{7}$ An extreme form of curvature astigmatism, frequently irregular, may arise in keratoconus, in corneal scarring, or following corneal transplants.

Rigid contact lenses may be used to correct irregular astigmatism by utilizing the tear film between cornea and contact lens (see page 19). If irregular astigmatism cannot be corrected with contact lenses and if vision is markedly reduced, consideration should be given to a comeal transplant to substitute a regular refractive surface for the diseased cornea.

Anisometropia is the condition in which the refractive error of each eye is different. Minor differences are nearly universal, but when there is a difference of more than 4 diopters, the difference in image sizes of the two eyes may cause symptoms. Marked anisometropia is a common cause of amblyopia. ${ }^{8}$

Aniseikonia is that condition in which the size or shape of the retinal

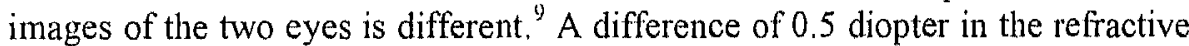
error gives rise to a size difference of about $1 \%$ in the retinal image. Most 
patients tolerate a difference up to $8 \%$ without symptoms. ${ }^{10}$ When the image size difference is greater than $5 \%$ because of an anisometropia, it seems likely that many patients suppress the image from one eye and do not have symptoms. ${ }^{11}$

Visual acuity

Many subjective tests have been proposed for the determination of visual acuity using pictures of different objects, circles, dots, letters and numerals.

Table 2-1. Visual acuity expressions

\begin{tabular}{llcl}
\hline $\begin{array}{l}\text { Snellen equivalent } \\
\text { (feet) }\end{array}$ & $\begin{array}{c}\text { Decimal equivalent } \\
\text { (minutes) }\end{array}$ & $\begin{array}{l}\text { LogMar } \\
\text { Equivalent }\end{array}$ \\
\hline $20 / 160$ & $6 / 48$ & 0.125 & +0.90 \\
$20 / 125$ & $6 / 37.5$ & 0.16 & +0.80 \\
$20 / 100$ & $6 / 30$ & 0.20 & +0.70 \\
$20 / 80$ & $6 / 24$ & 0.25 & +0.60 \\
$20 / 63$ & $6 / 18.9$ & 0.32 & +0.50 \\
$20 / 50$ & $6 / 15$ & 0.40 & +0.40 \\
$20 / 40$ & $6 / 12$ & 0.50 & +0.30 \\
$20 / 32$ & $6 / 9.4$ & 0.63 & +0.20 \\
$20 / 25$ & $6 / 7.5$ & 0.80 & +0.10 \\
$20 / 20$ & $6 / 6$ & 1.00 & 0.00 \\
$20 / 16$ & $6 / 4.8$ & 1.25 & -.10 \\
$20 / 12.5$ & $6 / 3.75$ & 1.60 & -.20 \\
$20 / 10$ & $6 / 3$ & 2.00 & -.30 \\
\hline
\end{tabular}

The Dutchman Snellen was the first to construct a system of test objects so arranged that a number could express acuity. In his test chart, the characters consist of letters, each stroke or space of which occupies an angle of 1 minute of arc, with the whole character occupying 5 minutes of arc at the stated distance.

Many expressions of relative acuity have been devised to attempt to record the value as a fraction, but the majority in common use compare the patient acuity with the average normal for that distance, "20/20" indicates the line read by average normal people at 20 feet. $6 / 6$ is the metric equivalent, used in Great Britain, and 1.0 is the decimal equivalent, used in the Netherlands. ${ }^{12}$ Modern visual acuity charts are designed so that the letter sizes on each line follow a geometric progression (i.e., change in a uniform step on a logarithmic scale). ${ }^{13}$ The accepted step size has been chosen to be $0.1 \log$ unit steps, which is the equivalent to the letter size changing by the factor of 1.2589 between lines. 
This standard gave rise to the logarithmic of the minimum angle of resolution (LogMAR) notation, as shown in Table 2-1.

In calculating the average visual acuity as standard deviation on a series of patients the geometric mean must be used. ${ }^{14}$ Statistical analysis of visual acuity, such as standard deviations, must be calculated using the logarithm of the visual acuity ${ }^{15}$ or logarithm of the visual angle (LogMAR). ${ }^{16}$ The format for reporting refractive surgical data in a standard, consistent manner has been described in the literature by $\mathrm{Koch}^{17}$, and Waring. ${ }^{18}$ In the chapters 3 to 10 of this thesis, mean visual acuity was calculated using LogMAR. 


\subsection{RIGID CORNEAL CONTACT LENS FITTING}

\section{Contact Lens Materials}

Rigid gas permeable (RGP) corneal contact lenses are devices which are applied to the cornea to correct the refractive error. "Primum non nocere"19 (first do no harm) not only is it a fundamental principle of medicine, it is particularly relevant to the fitting of contact lenses for non-therapeutic purposes. $^{20}$

Kevin M. Tuohy ${ }^{21}$ is credited as the inventor of the rigid corneal lens and its introduction has been marked as a distinct deviation from the standard principles previously accepted in the fitting of contact lenses. He was the first who developed a corneal bi-curve lens with an optical zone diameter of $8.5 \mathrm{~mm}$ and an overall diameter of $11.5 \mathrm{~mm}$. $^{22}$ Poly Methyl Methacrylate (PMMA) was the first contact lens material and has unsurpassed physical properties as a rigid contact lens. ${ }^{2.3}$

Combining hydrophobic silicone-containing monomers with methyl methacrylate to create silicone-acrylate polymers required the incorporation of wetting agents to restore clinically acceptable levels of surface wettability. By the incorporation of fluorine in the polymer matrix a biocompatible contact lens material was found. ${ }^{24}$ As a result, the surface of a fluoro-silicone-acrylate polymer appears to resist the adhesion of mucus and other tear film debris better, facilitating its removal and recreating an intact tear layer after each blink. ${ }^{25,26,27}$

Fluoro-silicone-acrylate polymers can also achieve better distribution of oxygen tension across the cornea and contact lens without compromising the corneal surface properties, important for contact lens wearing comfort. ${ }^{28}$

High quality lens surfaces are more difficult to fabricate in the new lens materials. The new lens materials also increase the susceptibility to breakage and reduce dimensional stability. They have decreased scratch resistance, and decreased surface wettability. Their increased flexibility can impair the ability of the contact lens to correct larger amounts of comeal astigmatism.

\section{Fitting aspects}

The refractive index of tears is nine-tenths that of the cornea. ${ }^{29}$ The fluid compartment created between the back surface of the contact lens and the cornea virtually neutralizes the corneal surface and replaces it optically with a new surface shaped by the concavity of a contact lens. 


\section{Review of the literature}

The fluid compartment formed between a rigid contact lens and cornea is itself a lens, having a power independent of that of the contact lens and eye. The tear compartment "fills in" the differences between the flat and steep meridians of an astigmatic cornea, and the power of the refractive error along the steepest meridian can be ignored.

The flatter corneal meridian becomes the reference for determining the power created by the tear lens, and the refractive error along this meridian, serves as a basis for calculation of the power needed by the contact lens. The tear compartment formed by a rigid contact lens functions optically as an extension of the cornea, having an anterior curvature identical to that of the posterior contact lens surface.

If the posterior surface of a rigid contact lens is spherical, the newly created corneal optical surface has an identical spherical convex curvature regardless of the true corneal topography. As a result, both regular and irregular corneal astigmatism is virtually neutralized by rigid contact lenses ${ }^{30}$ as is shown in this thesis.

\section{Physiological aspects of Rigid Contact Lenses}

In 1952, oxygen deprivation of the cornea was first proved ${ }^{31}$ (Sattler's veil). Since then, much has been learned about the oxygen requirements of the cornea, the pathophysiology of corneal hypoxia, and the mechanisms of corneal oxygen supply during contact lens wear. In 1984 it was estimated that an oxygen partial pressure of approximately $75 \mathrm{~mm} \mathrm{Hg}$ is required at the corneal surface to prevent measurable hypoxia-induced corneal edema. ${ }^{32}$

During contact lens wear, oxygen can reach the underlying corneal surface by tear exchange that occurs during blink-induced lens movement ${ }^{33,34}$ and by diffusion through the lens material. The diffusion rate is directly related to the oxygen permeability of the polymer (Dk) and inversely related to the lens thickness $(\mathrm{t}){ }^{35}$

The quotient of these two factors, $\mathrm{Dk} / \mathrm{t}$, is known as oxygen transmissibility. Fluorosilicone-acrylate polymers exhibit high oxygen permeability, because oxygen transmission through these materials is based on the volume of the intermolecular spaces created by the bulky siloxane ( $\mathrm{Si}-\mathrm{O}-\mathrm{Si}$ )containing moieties and the increased gas solubility contributed by its fluorine content. ${ }^{36,37}$

Accumulation of carbon dioxide $\left(\mathrm{CO}_{2}\right)$ in the stromal tissue due to hypoxia and hypercapnia (elevated $\mathrm{CO}_{2}$ tension) contribute to the decreased $\mathrm{pH}$ 


\section{Chapter 2}

in the corneal stroma, which is responsible for short- and long-term endothelial changes that have been observed as a result of contact lens wear. ${ }^{38,39}, 40$

Corneal endothelial polymegathism is a common and largely irreversible consequence of wearing gas-impermeable lenses ${ }^{41}$ and has been shown to be associated with an impaired capacity of the cornea to shrink after being subjected to hypoxic stress ${ }^{42,43}$ and stromal acidosis resulting from the accumulation of carbon dioxide and lactic acid. ${ }^{44,45}$

Fatt and coworkers ${ }^{46,47}$ were the first to describe the steady-state distribution of oxygen and carbon dioxide in the in-vivo cornea. Models of the oxygen distribution across the comea with contact lens wear are useful for estimating minimum transmissibility (Dk/t) values and further understanding of contact lens complications.

Recently a new mathematical model was presented for the oxygen distribution across the cornea during contact lens wear, including the effect of acidosis that increases comeal oxygen consumption. ${ }^{48}$ In that mathematical model, the minimum contact lens $\mathrm{Dk} / \mathrm{t}$ values necessary to avoid corneal edema during daily contact lens wear including the effect of acidosis, have been estimated for the open eye, between 23 and 35, and between 89 and 125 for the closed eye. The disadvantage of models includes the static and one-dimensional structure, neglecting corneal and contact lens variations with eccentricity and the effects of tear exchange.

There is considerable variation among subjects in their response to contact lens wear which is measured by: tear oxygen tension, ${ }^{49}$ the equivalent oxygen percentage (EOP) technique, ${ }^{50,51}$ corneal edema,${ }^{52,53}$ stromal $\mathrm{pH}^{54}$ and by the increased oxygen consumption caused by acidosis. ${ }^{55}$ 
Table 2-2. Rigid Gas Permeable contact lens materials with high Dk

\begin{tabular}{lllll} 
Material & $\mathrm{Dk}^{\dagger}$ & $\mathrm{Dk}^{2}$ & $\begin{array}{c}\text { Center thickness } \\
\text { (at Sph-3 O D) }\end{array}$ & $\mathrm{Dk} / \mathrm{t}^{3}$ \\
\hline Fluoroperm 151 & 100 & 151 & $0.17 \mathrm{~mm}$ & 59 \\
Boston XO & 100 & 140 & $0.17 \mathrm{~mm}$ & 59 \\
Boston Equa II & 85 & 127 & $0.17 \mathrm{~mm}$ & 50 \\
Quantum II & 97 & 135 & $0.17 \mathrm{~mm}$ & 57
\end{tabular}

Dk: This term is used to denote the permeability of rigid and soft contact lens materials. "D" is the inherent ability of the material to allow gas through. " $\mathrm{k}$ " represents the degree to which oxygen is solubilized within or on the material, since water plays some role in absorbing and assisting in the transport of oxygen. Dk/t: Refers to the transmissibility of a material when it is made into either a plus or minus lens. " $t$ " represents the thickness of a given lens. The significance of this measurement is that the amount of oxygen transmitted can vary depending on the thickness

1. ISO/Fatt 2. Polymer Technology Corporation, gas-to-gas method

3. at recommended center thickness

The current maximum $\mathrm{Dk} / \mathrm{t}$ of hydrogel contact lenses is about $30{ }^{56}$ whereas RGPs may approach 150 (table 2-2) and new silicon (Lotrafilcon A, Ciba Vision Corp, Duluth, GA, USA) soft contact lens materials are reported to be $140 .^{57}$ In these very high $\mathrm{Dk} / \mathrm{t}$ lenses, it is unlikely that complications will be caused by oxygen deprivation, but problems associated with inadequate tear flow and risk of bacterial infection will likely remain as valid reason to avoid extended wear use whenever possible.

If the avoidance of permanent morphologic changes of corneal endothelial cells is used as a measure of long-term daily contact lens-wearing tolerance, one can infer that rigid lenses fabricated from higher Dk polymers, as used in this thesis, are preferable to those fabricated from low Dk polymers.

Contact lens wear can induce corneal warpage, irregular astigmatism, ${ }^{58,5 \%}$ and corneal curvature and surface irregularity." In a population of patients screened for refractive surgery, one-third had abnormal corneal topography, and more than a third of the contact lens wearers showed evidence of corneal warpage by topography, including irregular astigmatism, loss of radial symmetry along an axis, or absence of normal flattening from center to the periphery of the cornea. ${ }^{61}$ 


\section{Fitting relationships}

The posterior surface of a contact lens determines its fitting relationship with the cornea. The back optic zone radius (dimensions are usually expressed in $\mathrm{mm}$ radius of curvature) are traditionally spherical in the center to provide satisfactory optical performance. ${ }^{62}$

The popularity of non-spherical peripheral curves has been increasing. The edges of rigid corneal lenses must be sufficiently elevated above the cornea to provide adequate clearance during blink-induced lens excursions. In the periphery, a series of flatter curves or aspherical peripheral curves accomplish this edge clearance. ${ }^{6.3}$ To maximize the tear exchange that occurs under a RGP lens during blink-induced movement lenses incorporated relatively wide and flat peripheral curves. $^{64,65}$

The introduction of computer-driven lathes has provided contact lens manufacturers with the capability of creating back surface designs that have a junctionless transition from a spherical base curve to a rapidly flattening periphery. ${ }^{66}$

The importance of the sensation created as the upper lid margin touches the edge of the lens has been established by Osborn. ${ }^{67}$ The most comfortable fitting pattern with respect to upper lid margin sensation is the high fitting pattern (Figure 2-3). ${ }^{68}$

One of the principal influences of the lens positioning and blink-induced excursion pattern is the degree of flattening of the superior and inferior corneal surfaces, as seen on the corneal topography. Excessive flattening of the cornea adjacent to the superior limbus impedes the upward movement of the contact lens, whereas the absence of significant flattening of the inferior periphery facilitates downward movement of the lens.

Another important influence on lens positioning is the friction that develops between the tarsal surface of the upper lid and the anterior surface of the lens. This is greatly influenced by the cross-sectional profile of the contact lens; the lenses with a minus power configuration position higher than lenses with a plus power configuration that are thicker in the center and become thinner at the edge.

The lens-cornea relationship is the third influence on the excursion pattern and lens position on the cornea. Flat-fitted lenses tend to position higher, whereas steep-fitted lenses usually assume a more central or apical position. 
Ideally, the lens should be pulled upward during the opening phase of each blink and than slide one or two millimeter downward in a smooth, consistent vertical movement. ${ }^{(1)}$

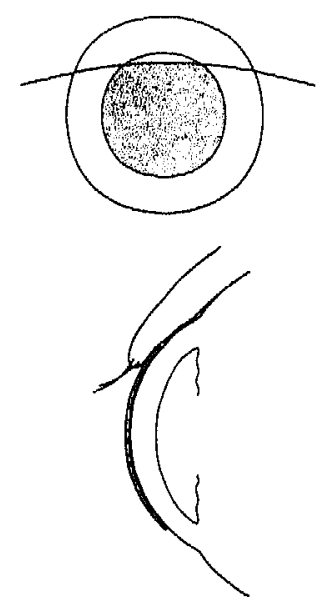

Figure 2-3. Upper-lid margin-lens resting position. The most comfortable fitting pattern with respect to the upper lid margin sensation is the high fitting pattern. (Figure: Gcertjan van Zonneveld)

The most accurate method of determining the performance of a specific lens design on a particular eye is to observe the fitting characteristics of trial contact lenses. ${ }^{71}$

The comea-lens relationship can be studied using the fluorescein patterns of the tear film during the blink-induced excursions of the RGP lens.

Evaluating contact lens fitting with trial lenses, allows the practitioner to anticipate the resting position and excursion patterns of RGP lenses. This facilitates choosing the definitive lens parameters that would be expected to optimize their clinical performance. ${ }^{71}$

To reduce or eliminate upper lid margin sensation and facilitate upper lid attachment, the average position of the center of the lens during a typical reflex blink cycle should lie above the center of the cornea.

The superior edge of the lens may reach and even overlap the superior limbus at the limit of its upward excursion. Flatter-fitted lenses may assume a higher resting position. 


\subsection{CORNEAL TOPOGRAPHY}

\section{Reflection technique}

The comea is the major refractive element of the eye. The corneal tear film-air interface provides about two-thirds of the vergence of the eye, and plays a critical role in the quality of the optics of the eye; because of this property, even small amounts of surface irregularity can reduce the quality of the retinal image. $^{72}$

The shape of the cornea, being the carrier of the tear film, is therefore of paramount importance for the optical quality of the eye and consequently for good vision. Numerous efforts have been made to provide qualitative and quantitative information about the corneal surface.

It has been known for more than 300 years that one can observe the regularity of corneal curvature through observation of a reflected geometric pattern from the convex corneal surface. ${ }^{73}$ In 1619 , Cristopher Scheiner realized that one could estimate corneal curvature by comparing the reflection of a window on the corneal surface. In 1880, Antonio Placido introduced the Placido disc $^{74}$ which is composed of alternating black and white rings with a central aperture through which one can view the virtual image formed by the reflection of the target, produced by the convex mirrors of the tear film. In the 19th century, Helmholtz developed the ophthalmometer, ${ }^{75}$ which led to the invention of the first keratometer by Javal for the measurement of the anterior radius of corneal curvature.

The modern autokeratometer generally improves repeatability of the measurements between observers. With these instruments we can measure only the central corneal spherocylindrical surface, but keratometry is not useful for measuring of corneas that are likely to depart from spherocylindrical optics, as commonly occurs in refractive surgery and corneal transplants.

Before the development of the videokeratoscope, the peripheral convex surface was measured by conventional keratometry, in the central and peripheral horizontal plane. Douthwaite proved recently that this method for assessing curvature and asphericity appears to hold promise as a method for quantifying corneal topography. ${ }^{76}$

The development of the photokeratoscope allows the clinician to evaluate the central and mid-peripheral corneal surface both quantitatively and qualitatively. ${ }^{77}$ Qualitative keratoscopy, the observation of reflections of multiple concentric circles from the corneal surface, preceded the evolution of 
computerized videokeratoscopy, frequently referred to as corneal topography. The reflective mires appear closer together on steeper parts of the cornea and further apart in flatter areas. If corneal astigmatism is present to more than a minimal degree, it changes the reflected circles to an elliptical shape, with the steep axis of the cornea corresponding to the minor axis of the ellipse where images are closer together. Localized changes, as from tight sutures after comeal transplant, cause distortion of the mires in the area of the suture compression.

Videokeratoscopes provide the ability to digitize the image and export data to various software programs for rapid quantitative analysis. The work of Klyce and Maguire ${ }^{78.79}$ culminated in the introduction of a color-coded contour map for the qualitative detection of variations in corneal curvature. After the introduction of powerful memory chips in personal computers in 1988, this technology was commercialized. ${ }^{80}$

\section{Videokeratoscope}

Placido-based videokeratoscopes comprise the vast majority of the units used in clinical practice today. All systems contain a transilluminated disc or cone (modified Placido disc), an imaging system consisting of an objective lens, a black and white camera, a video frame grabber, and a computer system. ${ }^{81}$ Each device must make a series of approximating calculations, which can be quite accurate on regular surfaces.

A long working distance, as used with the Alcon EyeMap EH-290 (Alcon Lab, Fort Worth, Tex, USA), can cause masking of the reflex by the eclipse of the nose and brow, but is less susceptible to focusing error than near-designed units. ${ }^{82}$

"Topography" implies shape and requires the generation of an X, Y, Z coordinate system. Attempting to create such a coordinate system from curvature data involves certain geometric assumptions about the cornea.

Generally, a Placido-based system generates "elevation" values by fitting the surface slope data to a predefined, typically spherical mathematical model (Figure 2-4). While reasonable for normal corneas, this assumption is a potential source of error in the post-surgical or abnormal cornea, which may have nonlinear changes in curvature (eg, do not conform to a known conic section). ${ }^{82}$

In addition, abnormalities of the tear film can result in poor quality photographs of the mires and misleading results. ${ }^{8.84}$ Imaging of abnormal corneas can lead to virtual images that are not properly focused due to a lack of depth resolution or due to concave areas on the corneal surface. As a consequence, the recorded image may contain unresolved or ambiguous parts. ${ }^{8.5}$ 


\section{Chapter 2}

We have to keep in mind that all Placido-based topographers have a central blind spot that is not directly measured, due to the place of the camera. The size of the unmeasured zone varies and increases as comeal curvature decreases; for a 37.5-diopter cornea, this diameter is $0.6 \mathrm{~mm}$. Comeal power values central to the measured zones are extrapolated from paracentral points using a spherical algorithm. ${ }^{86}$

Placido disc-based videokeratography has its limitations but remains the most successful commercially available methodology for corneal topographical analysis because its sensitivity in regular surfaces is high. Topography instruments with long working distance proved to have an accuracy in six test objects with no single point error greater than $0.25 \mathrm{D} .{ }^{87}$ Reproducibility on spherical PMMA test objects were also within $0.25 \mathrm{D}^{88.89}$

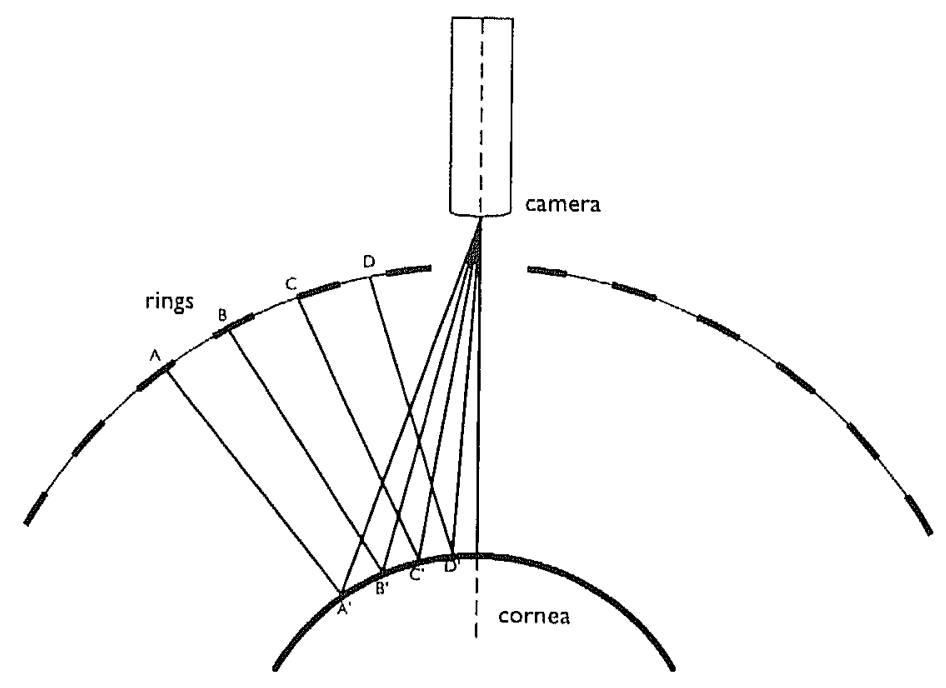

Figure 2-4. The light rays emanated from the luminous ring mires placed at points $A, B, C$ and $\mathrm{D}$ penetrate into the video-camera after reflecting onto the tearfilm at points $\mathrm{A}^{\prime}, \mathrm{B}, \mathrm{C}$ ' and $\mathrm{D}^{\prime}$. (figure: Geertjan van Zonneveld)

Comeal topography devices measure the radius of curvature for a comparable sphere, with the same tangent as the point in question.

The axial formula is based on the axial distance measured from the corneal surface to the axis of the videokeratoscope. ${ }^{9 /}$ More simply, it is a 
measure of curvature with the constraint that all the centers of rotation must fall on the axis defined by the optical axis of the videokeratoscope.

The maps tend to be smooth with little noise ${ }^{91}$ because the centers of rotation are forced to fall on a known axis. For the central pupillary area, where paraxial optics applies, the maps are a reasonable approximation of refractive power.

The instantaneous, local tangential curvature map is obtained by computing the instantaneous radius of curvature for each point without the constraint that the centers of rotation fall on the axis of the videokeratoscope.

Both, axial distance and radius of curvature are in the tangential or meridional plane, therefore the term tangential, although correct, does not adequately discriminate between the two quantities and it is important for the user to understand the difference. ${ }^{92}$

Unlike the axial map, the tangential map does not fix one of the variables, and therefore it is inherently noisier. Tangential maps do represent local changes and peripheral data better than axial maps, however, ${ }^{93}$ but are not reflective of peripheral refractive power.

Mathematically, the algorithms to compute a tangential map contain firstand second-order derivatives, whereas those to compute an axial map contain only first-order derivatives.

Refractive power maps are useful in understanding the effects of surgery and the optical properties of the cornea. To determine the refractive power of the cornea at any point, one must apply Snell's law, the same as used for the keratometer: $P=0.3375 / R$ where $P$ is the corneal power in diopters, $R$ is the local radius of curvature in meters, and the constant 0.3375 is the difference between the refractive index of air and of an equivalent of the cornea. The value of 1.3375 is chosen because it provides the most appropriate estimate of dioptric power differences between distinct points of the cornea. ${ }^{14}$ Clinically, refractive power is not fixed but is relative to the object distance, assumed optical infinity by using parallel rays of light from a distant source.

The algorithms vary, and measurements vary considerably in the periphery where errors in corneal refractive power measurement are inherently greater. $^{95,96}$ 


\section{Classification of corneal topography patterns}

Surface topography of most normal corneas is distinguished by three illdemarcated zones: 1: A central cap that is characterized by a slow rate of flattening from center to periphery. 2: a concentric zone having a faster rate of flattening best described by a series of hemi-meridian ellipses. 3 : a transitional zone in which the curvature of the cornea merges with the much flatter curvature of the sclera. ${ }^{97}$

The limbal zone is highly variable and difficult to measure by optical instruments. The common presentation technique of the data is the color-coded map of corneal powers. ${ }^{98}$

A color spectrum was chosen (Fig 2-5) so that cool colors were associated with low corneal powers and warm colors were associated with high corneal powers. ${ }^{99}$ While many different scales exist, most scales fall into two broad categories: absolute and relative, or normalized. In the absolute scale, the number of colors, step size, and range are constant. An absolute scale should always be used to facilitate comparisons over time and between patients. The relative scale is determined by the flattest and steepest values of the cornea, so it is not fixed and will vary for each image processed.

To complement the information provided by the color maps, a number of quantitative indexes have been developed. Simulated Keratometry (SimK), ${ }^{102}$ is the average of points, measured in the steepest and flattest radius of curvature in the central $3.2 \mathrm{~mm}$; several investigators have pointed out that these $\operatorname{sim} \mathrm{K}$ values may only be valid on normal corneas. ${ }^{100,101}$

Surface Regularity Index (SRI) ${ }^{102}$ is calculated with an equation based on the difference in power gradient between successive mire pairs. ${ }^{103}$ When the anterior corneal surface is regular, a lower SRI value is obtained which may be representative for the prediction of spectacle-corrected visual acuity. ${ }^{104,105}$

Naturally occurring regular astigmatism reveals itself in videokeratography as a bow-tie pattern. ${ }^{106}$ Bogan and coauthors ${ }^{107}$ found that $22 \%$ of the corneas had round patterns; $21 \%$ had oval patterns; $7 \%$ had irregular patterns and $50 \%$ had bow-tie patterns. Kanpolat and coauthors ${ }^{108}$ found that $33 \%$ of corneas had an asymmetric bow tie, $29 \%$ had a symmetric bow tie, $14 \%$ were round, $12 \%$ were irregular and $11 \%$ had oval patterns.

In a recent study Budak and coauthors ${ }^{1119}$ discussed the patterns found by Bogan and coauthors, Alvi and coauthors ${ }^{110}$ and Kanpolat and coauthors. 


\section{Review of the literature}

DOB: 16081978

\begin{tabular}{|l|}
\hline Dioptric Plot \\
\hline Tangential \\
\hline K3.12 13710000 \\
KF: $42.000 @ 100$ \\
KD: 0.370 \\
Real K/ 1 PL @ 1.60 \\
SF: 0.75 E: 0.50 \\
SRI: 0.06 \\
VID: $11.29 \mathrm{~mm}$ \\
\hline
\end{tabular}

\section{Pupil Offset \\ $X: 0.18 \quad Y: 0.04$}

\begin{tabular}{|l|}
\hline Dioptric Plot \\
\hline Tangential \\
\hline KS: 42.370 (1) 001 \\
KF: 42.000 100 \\
KD: $0.37 D$ \\
Real K/1PI 1.80 \\
SF: 0.75 E: 0.50 \\
SRI: 0.06 \\
VID: $11.28 \mathrm{~mm}$ \\
\hline
\end{tabular}
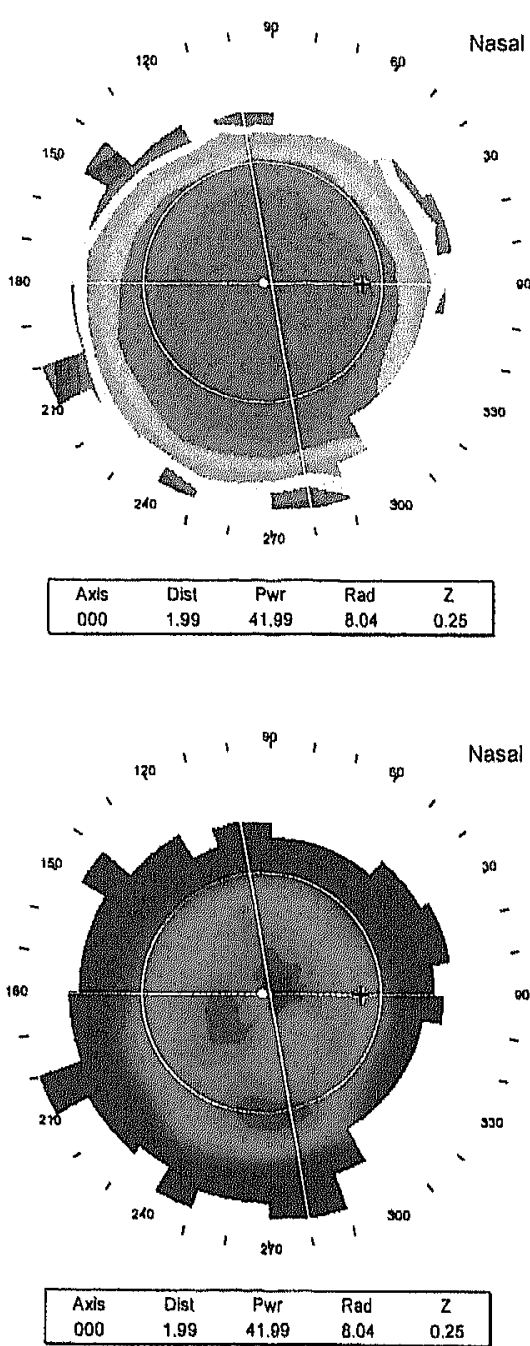$$
1.99
$$

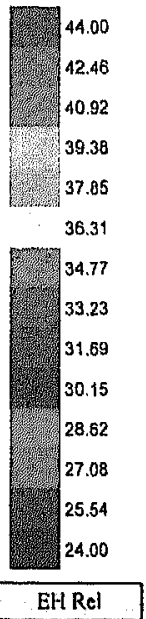

EH Rel

$$
\text { Pupil Oflset }
$$

Figure 2-5. Videokeratography image of normal virgin a-spherical cornea with a round pattern, both from the same eye. The upper map is in the tangential relative scale, and the lower map is in the tangential absolute scale. The relative steps are of $1.54 \mathrm{D}$ and the steps in the absolute scale are of 0.5 D. The cursor is placed $1.99 \mathrm{~mm}$ nasally and can be seen on both maps pointing out a radius on that spot of $8.04 \mathrm{~mm}$. Concentric areas of increasing curvature can be observed. The dioptric plot shows a homogeneous progression towards the periphery, which would indicate a regular cornea with a spherical refractive outcome. The surface regularity index $(\mathrm{SRI})$ is very low 0.06 . 
Budak found in axial maps circular patterns with a central bow tie in 28.1 $\%$ of the patients, a symmetric bow tie in $23.5 \%$, and circular, including oval and the kidney- and teardrop patterns in $21.6 \%$ of the patients.

Rasheed and coauthors ${ }^{111}$ developed a classification scheme that, even in the hands of less experienced observers with minimal training, gave consistent results.

Males are likely to have flatter corneas than females but the asphericity is likely to be the same in the two genders. ${ }^{112}$ The presence or absence of lid pressure tended to have influence on corneal shape. ${ }^{11}$

The cornea is naturally a prolate ellipsoid with cylinder added to that geometry. The 3 to $4 \mathrm{D}$ flattening occurring between the corneal center and the periphery turns the fan shape into the bow-tie configuration as seen in the contour maps. ${ }^{114}$ The aspheric nature of the cornea corrects approximately onehalf of the eye's spherical aberration. ${ }^{115}$

\section{Corneal topography as a tool in rigid contact lens fitting}

It has become clear with the availability of computerized corneal topography analysis that there is a new capability that can be used to improve contact lens fitting (Table 2-3). Videokeratoscopes mathematically reconstruct the shape of the cornea; these data can be used to evaluate the relationship between the contact lens and the corneal surface ${ }^{116}$ in both normal and pathological corneas. ${ }^{117,118,119,120,121}$

In a normal patient population, the studies in Table 2-3 suggest that most videokeratoscope based contact lens software packages may be beneficial in increasing RGP fitting efficiency. However, the present programs cannot evaluate the effects of lid movement and lid force which currently only can be assessed with diagnostic lenses. Videokeratoscopy has been shown to be beneficial in irregular corneas by enhancing the diagnosis of corneal pathology, monitoring corneal changes, and providing measurements of curvature to aid in qualitative and quantitative contact lens selection, as demonstrated in this thesis. 


\section{Review of the literature}

Table 2-3 Review of the literature in which the videokeratoscope designates the back optic zone radius (BOZR) in rigid gas permeable (RGP) contact lens fitting for normal unoperated corneas.

\begin{tabular}{llllll}
\hline Author & Year & No CL design & Software & Differences* \\
\hline Rabinovitz $^{122}$ & 1993 & 33 & aspheric & CMS & rational selection of BOZR \\
Szczotka $^{123}$ & 1994 & 22 & tri-curve & Pro-Fit 3.1 & less time consuming with computer \\
Donshik $^{124}$ & 1996 & 26 & by computer EyeSys 2.11 & diagnostic lens prefers \\
Douthwaite $^{125}$ & 1997 & 20 & tri-curve & Douthwaite & none \\
Bufidis $^{126}$ & 1998 & 50 & aspheric & TMS-1 & software proposed diameter smaller \\
& & & & \\
\hline
\end{tabular}

* differences between software based BOZR and clinical based BOZR with diagnostic lenses 


\subsection{CORNEAL KERATOPLASTY SURGERY}

From a pathophysiological point of view, there are four indications to perform keratoplasty surgery: optical, therapeutic, tectonic, and cosmetic indications. ${ }^{127,128,129,130}$

The first indication is optically ${ }^{131}$ in diseases like keratoconus, ${ }^{132}$ corneal dystrophies ${ }^{133,134}$ marginal degenerations, ${ }^{135}$ and post-inflammatory- or traumatic scarring. ${ }^{136}$ The second indication is therapeutic, used to remove infiltrated corneal tissue in eyes unresponsive to conventional anti-microbiological or antiviral therapy. ${ }^{137}$ The third indication is tectonic. It involves restoring and preserving corneal anatomy in eyes with severe corneal changes such as stromal thinning, ${ }^{138}$ corneal melting, ${ }^{139}$ and descemetoceles. The fourth indication is cosmetic, which is performed to improve the appearance of the eye.

New surgical techniques in lamellar keratoplasty, including phototherapeutic keratectomy, deep anterior lamellar keratoplasty, and posterior lamellar keratoplasty, have recently become available. These procedures broaden the array of treatments for corneal disorders and may be used as alternatives to penetrating keratoplasty. ${ }^{140,141}$

\section{Lamellar keratoplasty}

Lamellar grafting maintains an important place in the armamentarium of modern corneal surgeons because it has several advantages over penetrating keratoplasty. ${ }^{142,143}$ Lamellar grafting is an extraocular procedure, and the criteria for harvesting donor tissue are less stringent with respect to the state of the endothelium. ${ }^{44}$ Risks for wound dehiscence and allograft rejection are decreased ${ }^{145}$ but vision-reducing graft-host interface problems and the difficulty of the surgical technique limit the operation. ${ }^{146}$ Lamellar corneal grafts may be used for the replacement of abnormal superficial corneal tissue, such as superficial scars, keratoconus, superficial degenerations and dystrophies.

Lamellar keratoplasties have been performed since the late 1950's. However, even the lamellar keratoplasty pioneers such as Hallermann, McCulloch, Malbran ${ }^{147}$ and Pouliquen, who performed lamellar keratoplasties in the 1960 's as more than half of their total number of keratoplasties, later preferred the better optical results obtained with penetrating keratoplasty.

In 1982, Morrison and Swan ${ }^{148}$ demonstrate an incomplete healing of Descemet's membrane to the overlying stroma tissue. In 1985. Archila ${ }^{149}$ describes for the first time a successful dissection technique with an intrastromal air injection in 10 patients. Continued progress in microsurgical instruments and operation techniques improved the dissection down to Descemet's membrane. ${ }^{150}$ 
In 1997, Melles and coauthors developed a technique called deep anterior lamellar keratoplasty. The technique consists of filling the anterior chamber with air and the air-to-endothelium interface makes the posterior corneal surface visible in order to estimate the depth of the surgical blade. ${ }^{151}$

Visual acuity and astigmatism results following lamellar keratoplasty

Table 2-4 Dissection techniques, visual acuity and astigmatism outcome following lamellar keratoplasty.

\begin{tabular}{lllllll}
\hline Author & Year & No & $\begin{array}{l}\text { Dissection } \\
\text { technique }\end{array}$ & $\begin{array}{l}\text { BCVA } \\
\text { mean } \pm \text { SD }\end{array}$ & $\begin{array}{l}\text { Cylinder } \\
\text { mean } \pm \text { SD }\end{array}$ & $\begin{array}{l}\text { Follow-up mos } \\
\text { mean } \pm \text { SD }\end{array}$ \\
\hline Price $^{152}$ & 1989 & 6 & IA & $20 / 32 \pm 0.2$ & $0.88 \pm 1.4 \mathrm{D}$ & $10.6 \pm 4.5$ \\
Haimovici $^{153}$ & 1991 & 11 & microkeratome & $20 / 40 \pm 0.2$ & NR & $13.2 \pm 11.5$ \\
Hanna $^{154}$ & 1991 & 11 & microkeratome & $20 / 40 \pm 0.2$ & $2.8 \pm 1.4 \mathrm{D}$ & $24.1 \pm 8.9$ \\
Benson $^{155}$ & 1993 & 27 & LD & $20 / 32 \pm 0.2$ & $2.49 \pm 1.7 \mathrm{D}$ & $21.0 \pm 3.2$ \\
Sugita $^{156}$ & 1997 & 113 & hydrodelamination $20 / 40 \pm \mathrm{NR}$ & $\mathrm{NR}$ & $32.0 \pm 18.7$ \\
Krumeich $^{157}$ & 1997 & 10 & LD & $20 / 32 \pm \mathrm{NR}$ & $2.5 \mathrm{D} \pm \mathrm{NR}$ & $15.1 \pm 9.7$ \\
Tsubota $^{158}$ & 1998 & 17 & LD & $20 / 25 \pm \mathrm{NR}$ & $3.2 \pm 2.3 \mathrm{D}$ & $6.0 \pm 0.0$ \\
Krumeich $^{159}$ & 1998 & 33 & guided trephine & $20 / 32 \pm 0.2$ & $2.22 \pm 1.1 \mathrm{D}$ & $24.0 \pm 0.0$ \\
Soong $^{160}$ & 1999 & 52 & LD & $20 / 50$ in $63 \%$ NR & $36.0 \pm 23.1$ \\
Panda $^{161}$ & 1999 & 24 & LD & $20 / 63 \pm \mathrm{NR}$ & $\mathrm{NR}$ & $12.0 \pm 0.0$ \\
Amayem $^{162}$ & 2000 & 24 & IA & $20 / 25 \pm 0.2$ & $2.54 \pm 0.8 \mathrm{D}$ & $13.1 \pm 1.4$ \\
Melles $^{163}$ & 2000 & 68 & OM & $20 / 25 \pm 0.1$ & $2.6 \pm 1.6 \mathrm{D}$ & $12.0 \pm 0.0$ \\
\hline
\end{tabular}

$\mathrm{LD}$, lamellar dissection after partial corneal trephination; IA, lamellar dissection after intrastromal air injection; $O M$, lamellar dissection with optically monitored dissection depth; BCVA, best corrected visual acuity; NR, not reported.

Recent lamellar keratoplasty clinical studies (Table 2-4) showed that mean postoperative best-corrected visual acuity ranged from $20 / 63^{161}$ to $20 / 25,{ }^{158,163}$ and that mean astigmatism outcome varied from $0.88^{152}$ to $3.2 \mathrm{D}^{158}$ In the 68 eyes undergoing the technique of Melles and co-workers, mean postoperative best-corrected visual acuity was $20 / 25 \pm 0.1$ and astigmatism was $2.6 \pm 1,6 \mathrm{D}$ at one year after surgery. ${ }^{164}$ 
Techniques to improve visual performance after lamellar keratoplasty

In reviewing the literature, we noticed that all patients needed at least spectacles to achieve best corrected visual acuity, and that acuity improved progressively during the first two years after surgery. ${ }^{152}$ Rigid gas permeable contact lenses can be used to correct irregular astigmatism and anisometropia following lamellar keratoplasty.

To our knowledge, the contact lens fitting technique following lamellar keratoplasty is only described in cases for persistent epithelial defects, managed with a soft bandage contact lens. ${ }^{165}$ Soong and coauthors ${ }^{161}$ fitted rigid contact lenses in 15 patients without explaining their fitting technique. Amayem and coauthors ${ }^{163}$ and Panda and coauthors ${ }^{162}$ fitted one rigid lens to correct astigmatism; however, none of them mentioned their fitting technique.

In chapter 4 we evaluate the safety and efficacy of early visual rehabilitation with a new contact lens fitting technique in patients following deep lamellar keratoplasty.

\section{Penetrating keratoplasty}

Full-thickness corneal transplants involve the replacement of diseased cornea by a graft of homologous tissue. As the realization of the importance of the endothelium became more widespread, penetrating keratoplasty became more common. Continued progress in microsurgical techniques and corneal storage with resulting improvements in corneal survival and refractive results after penetrating keratoplasty accounts for the current predominance of fullthickness versus lamellar grafts. The Eye Bank Association of America and Tissue banks International have estimated that about 36.000 penetrating keratoplasties and only about 400 lamellar keratoplasties were performed in the United States in $1999 .{ }^{166}$ The major indication for penetrating keratoplasty at the end of last century in Europe was keratoconus, before that time it was corneal edema. ${ }^{167}$

Most surgeons routinely use a donor button 0.25 to $0.5 \mathrm{~mm}$ larger than the host bed. When the donor button is transferred onto the host bed, fixation of the graft is usually by eight interrupted and one continuous running suture. Sometimes, mostly in Fuchs' dystrophy patients, a triple procedure is performed, in which a combined penetrating keratoplasty and cataract extraction is performed. ${ }^{168}$ 
Visual acuity and astigmatism results after penetrating keratoplasty

It is estimated that every year around 700 penetrating keratoplasties are performed in the Netherlands (Table 2-5).

Table 2-5 Indications for penetrating keratoplasty in The Netherlands between 1995 and 2000.

\begin{tabular}{lllllll}
\hline Indication & 1995 & 1996 & 1997 & 1998 & 1999 & 2000 \\
\hline Keratoconus & 121 & 120 & 116 & 83 & 99 & 95 \\
Bullous kerato. & 134 & 141 & 141 & 132 & 119 & 103 \\
Fuch's & 125 & 107 & 117 & 116 & 150 & 125 \\
Allograft failure & 112 & 88 & 77 & 68 & 79 & 78 \\
Herpes & 52 & 54 & 52 & 59 & 58 & 31 \\
Ulcus & 24 & 20 & 25 & 31 & 16 & 23 \\
Trauma & 24 & 15 & 16 & 19 & 12 & 24 \\
Buphthalmos & 2 & 7 & 4 & 5 & 3 & 0 \\
Unknown & 253 & 247 & 214 & 157 & 174 & 186 \\
Total: & 847 & 799 & 762 & 670 & 710 & 665 \\
& & & & & &
\end{tabular}

Information gratefully provided by the NOG Cornea Workgroup Kok-van Alphen

During the first months following penetrating keratoplasty, functional visual acuity is not always possible. When the wound edges are shrunk, and the center of the transplant is more regular, functional visual acuity can be obtained, which may take up from six months to two years after surgery. Several reports ${ }^{169,170}$ demonstrate that the majority of patients require optical correction for functional visual acuity after keratoplasty. Recent keratoplasty clinical studies (Table 2-6) showed that mean best corrected visual acuity ranged from $20 / 63^{175}$ to $20 / 25,{ }^{180,183}$ and that mean refractive astigmatism outcome varied from $2.23^{172}$ to $5.0 \mathrm{D} .{ }^{183}$ Postoperative visual correction following penetrating keratoplasty usually includes spectacles, but in cases of high postoperative anisometropia or irregular astigmatism optimal visual restoration may be obtained by contact lenses. ${ }^{171}$ 


\section{Chapter 2}

Table 2-6 Visual acuity and refractive astigmatism following penetrating keratoplasty

\begin{tabular}{lllllll}
\hline Author & Year & No & $\begin{array}{l}\text { sutures } \\
\text { in/out }\end{array}$ & $\begin{array}{l}\text { BCVA } \\
\text { mean } \pm \text { SD }\end{array}$ & $\begin{array}{l}\text { Cylinder } \\
\text { mean } \pm \text { SD }\end{array}$ & $\begin{array}{l}\text { Follow-up mos } \\
\text { mean } \pm \text { SD (range) }\end{array}$ \\
\hline Serdarevic $^{172}$ & 1995 & 25 & out & $20 / 32 \pm 0.2$ & $2.23 \pm 1.7$ & $15.0 \pm 0.0$ \\
Koralewska $^{173}$ & 1996 & 77 & out & $20 / 40$ in $84 \% *$ & $3.75 \pm \mathrm{NR}$ & $15.5 \pm \mathrm{NR}(3-40)$ \\
Silbiger $^{174}$ & 1996 & 68 & out & $20 / 27 \pm \mathrm{NR}$ & $\mathrm{NR}$ & $48.0 \pm 0.0$ \\
Yorston $^{175}$ & 1996 & 216 & out & $20 / 63$ in $73 \% *$ & $4.3 \pm \mathrm{NR}$ & $27 \pm \mathrm{NR}$ \\
Pineros $^{176}$ & 1996 & 126 & out & $20 / 40$ in $64 \% *$ & $3.9 \pm 1.9$ & $100.0 \pm 57.6$ \\
Filatov $^{177}$ & 1996 & 32 & out & $\mathrm{NR}$ & $3.30 \pm 1.3$ & $46.3 \pm \mathrm{NR}$ \\
Buzard $^{178}$ & 1997 & 104 & out & $20 / 25 \pm 0.2$ & $3.10 \pm 1.7$ & $42.0 \pm 21.6$ \\
Karabatsas $^{179}$ & 1998 & 51 & in & $\mathrm{NR}$ & $3.12 \pm 2.6$ & $12.0 \pm 0.0$ \\
Ruhswurm $^{180}$ & 1999 & 31 & out & $20 / 25 \pm 0.2$ & $3.57 \pm 1.4$ & $36.0 \pm 0.0$ \\
Olson $^{181}$ & 2000 & 93 & out & $20 / 25$ in $87 \% *$ & $2.76 \pm 2.0$ & $24.0 \pm 0.0$ \\
Brahma $^{182}$ & 2000 & 18 & in & $20 / 25 \pm \mathrm{NR}$ & $\mathrm{NR}$ & $18.0 \pm 0.0$ \\
Lim $^{183}$ & 2000 & 93 & out & $20 / 40$ in $86 \% *$ & $5.0 \pm 3.0$ & $46 \pm \mathrm{NR}(12-62)$ \\
Brierly $^{184}$ & 2000 & 123 & $75 \%$ out & $20 / 32 \pm 0.3$ & $2.67 \pm 2.0$ & $18.0 \pm 0.0$
\end{tabular}

NR, not reported; BCVA, best-corrected visual acuity; *, percentage of the cases

\section{Complications after penetrating keratoplasty}

In penetrating keratoplasty irregular astigmatism can result from wound configuration abnormalities ${ }^{185}$ such as ovality, overcut, ${ }^{186}$ dehiscence, a thin recipient cornea, graft elevation, ${ }^{187}$ or uneven tension on interrupted sutures, ${ }^{188}$ unselected suture removal, ${ }^{189}$ and irregularity of healing. ${ }^{190}$ Also the donor graft spherical equivalent power influences the spherical equivalent corneal power after keratoplasty. ${ }^{191}$ Therefore all keratoplasty patients must be fully apprised of the probability that they may require a contact lens or spectacle correction postoperatively for functional vision, i.e. for the functional success of their transplants. ${ }^{192}$

Corneal topography is helpful in evaluating and managing patients following penetrating and lamellar keratoplasty. Computer-based analysis provides useful information beyond visual inspection of keratoscope images in markedly irregular corneas. ${ }^{193}$ Karabatsas and coauthors ${ }^{194}$ described poor 
quality videokeratoscopic images in a large percentage (18\%) of grafted corneas. This was due to irregular astigmatism, poor tear film distribution, and irregularities of epithelial healing. In another study, Karabatsas and coauthors ${ }^{195}$ proposed a classification system for topographic patterns after penetrating keratoplasty. Ibrahim and coauthors ${ }^{196}$ also classified corneal topography after penetrating keratoplasty. They found five patterns, with a prolate bow tie pattern in $30 \%$ of the patients, an oblate bow tie pattern in $30 \%$, a mixed prolate- and oblate bow tie pattern in $17 \%$, an asymmetric pattern in $9 \%$ and a steep/flat pattern in $14 \%$ of the patients. Computer-generated indices of corneal asymmetry and regularity correlated well with Snellen visual acuity measurements. ${ }^{197}$ The greatest surface changes occurred during the first postoperative month, where after the axis of astigmatism was stable ${ }^{998}$ An early application of corneal topography following keratoplasty involved patients with high astigmatism requiring suture adjustment ${ }^{199}$ or selective removal to reduce astigmatism. ${ }^{201,201,202}$ Videokeratography is also used as a guide for the placement of relaxing ${ }^{203}$ or arcuate incisions ${ }^{204}$ and other surgical interventions to reduce high astigmatism after penetrating keratoplasty.

Dana and coauthors ${ }^{205}$ registered suture erosions in one hundred eyes following penetrating keratoplasty. Seventy-one percent presented with broken sutures 36 months postoperatively, and $29 \%$ with intact but loosened, eroded sutures. Eyes that had been subjected to keratoplasty for inflammatory conditions presented with suture erosion 10 months earlier than did those that had been subjected to keratoplasty for non-inflammatory conditions. Contact lens wear is impossible when suture erosion is present.

Primary graft failure is a rare complication of penetrating keratoplasty. ${ }^{206,2017}$ Graft failure refers to any graft that does not retain transparency sufficient for adequate vision. In a large longitudinal study in which 1806 eyes were included, the incidence of graft failure was $6.1 \%{ }^{208}$ Another study found the main causes of graft failure $(8.2 \%)$ were graft rejection, ${ }^{201}$ mostly in re-grafted patients $(37.9 \%) .{ }^{210}$ Endothelial failure $(2.4 \%)$, mostly from low initial endothelial cell density, ${ }^{211}$ infection $(2.4 \%)^{212}$ and glaucoma $(2.1 \%)^{213}$ are the other main causes of graft failure. Corneal grafts may fail at any time following surgery. ${ }^{214,215,216}$ All rejection forms have to be treated by the ophthalmologist with steroids.

\section{Surgical techniques to improve visual performance after penetrating keratoplasty}

Because intraoperative control of postoperative astigmatism has proved unreliable, ${ }^{217}$ van Meter and coauthors ${ }^{218}$ and Lin and coauthors ${ }^{219}$ recommended a technique with adjustments of the running sutures at the slit lamp within a 


\section{Chapter 2}

month following the surgical procedure. Selective removal of individual interrupted sutures has been proven to be effective in the reduction of astigmatism after penetrating keratoplasty, ${ }^{220,221}$ and so is the removal of running sutures. ${ }^{222}$ Lustbader and coauthors ${ }^{223}$ and Limberg and coauthors ${ }^{224}$ were the first who recommended relaxing incisions or compression sutures or a combination of these to reduce astigmatism after all sutures have been removed.

Table 2-7 Surgical treatments for the reduction of post-penetrating keratoplasty astigmatism after suture removal.

\begin{tabular}{|c|c|c|c|c|c|c|}
\hline \multirow{2}{*}{ 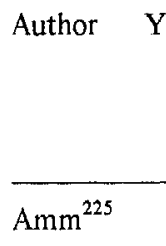 } & \multicolumn{2}{|c|}{ Year Treatment } & \multirow{2}{*}{$\begin{array}{l}\text { No } \\
\text { of eyes } \\
16\end{array}$} & \multirow{2}{*}{$\begin{array}{l}\text { Cylinder } \\
\text { before treatment } \\
\text { mean } \pm \mathrm{SD} \text { cyl } \\
5.73 \pm \mathrm{NR}\end{array}$} & \multicolumn{2}{|c|}{$\begin{array}{l}\text { Cylinder } \\
\text { after treatment } \\
\text { mean } \pm \mathrm{SD} \text { cyl }\end{array}$} \\
\hline & 1996 & PARK & & & $2.9 \pm N R$ & 4/16 haze grade II \\
\hline Lazzaro $^{226}$ & 1996 & PARK & 7 & $5.32 \pm 2.0$ & $2.79 \pm 1.8$ & 2/7 loss BSCVA \\
\hline Tuunanen $^{227}$ & ${ }^{27} 1997$ & PARK & 10 & $5.98 \pm 2.3$ & $4.28 \pm 2.4$ & 4/10 haze grade II \\
\hline Yoshida $^{228}$ & 1999 & PARK & 17 & $5.29 \pm 3.4$ & $2.48 \pm 2.0$ & $6 / 17$ increase cylinder \\
\hline Bansal $^{229}$ & 1999 & PARK & 10 & $5.80 \pm N R$ & $3.20 \pm N R$ & $5 / 10$ haze grade II \\
\hline Koffler $^{230}$ & 1996 & $\mathrm{IN}$ & 20 & $9.46 \pm N R$ & $5.3 \pm N R$ & $3 / 20$ loss BSCVA \\
\hline Chastang ${ }^{231}$ & 1997 & $\mathbb{I N}$ & 10 & $6.1 \pm 1.7$ & $2.85 \pm 1.3$ & none \\
\hline $\mathrm{McNeill}^{232}$ & 1999 & $\mathrm{CS}$ & 54 & $6.44 \pm 2.5$ & $5.23 \pm N R$ & none \\
\hline Solomon ${ }^{233}$ & 1999 & $\mathbb{I N}$ & 20 & $7.75 \pm 2.1$ & $3.90 \pm 2.0$ & 4/20 perforations \\
\hline Koay $^{234}$ & 2000 & $\operatorname{Cs}$ & 34 & $9.14 \pm 4.4$ & $3.59 \pm 1.9$ & none \\
\hline
\end{tabular}

cyl, cylinder; IN, incisions; CS, relaxing incisions combined with compression sutures; NR, not reported; PARK, Photoastigmatic refractive keratectomy; loss of BSCVA, loss of two or more Snellen lines of best spectacle corrected visual acuity.

Recent literature (Table 2-7) confirms their findings and demonstrates an astigmatic reduction ranging from $1.25^{232}$ to $5.55 \mathrm{D} .^{234}$ Photoastigmatic refractive keratectomy (PARK) may reduce astigmatism, but the uncertain refractive outcome and formation of stromal scarring in a great number of patients do not make PARK the treatment of first choice. ${ }^{229}$ 


\section{Review of the literature}

Table 2-8 LASIK for the reduction of post-keratoplasty anisometropia and astigmatism.

\begin{tabular}{|c|c|c|c|c|c|c|c|c|}
\hline \multirow{4}{*}{$\begin{array}{l}\text { Author } \\
\text { Year } \\
\text { Parisi }^{235}\end{array}$} & \multirow{4}{*}{$\begin{array}{c}\begin{array}{c}\text { No } \\
\text { of eyes }\end{array} \\
3\end{array}$} & \multirow{3}{*}{\multicolumn{2}{|c|}{$\begin{array}{l}\text { Before LASIK } \\
\text { Sph Cyl } \\
\text { mean } \pm \text { SD }\end{array}$}} & \multicolumn{5}{|c|}{12 months after LASIK } \\
\hline & & & & \multirow{2}{*}{\multicolumn{2}{|c|}{$\begin{array}{l}\mathrm{Sph} \quad \mathrm{Cyl} \\
\text { mean } \pm \mathrm{SD}\end{array}$}} & \multirow{2}{*}{\multicolumn{3}{|c|}{$\begin{array}{l}\text { Change in BCVA (no of eyes) } \\
\text { improved } \uparrow \text { - decreased } \dagger \text { - unchanged }\end{array}$}} \\
\hline & & & & & & & & \\
\hline & & -0.25 & 3.08 & 0.75 & 2.66 & 0 & 1 & 2 \\
\hline 1997 & & \pm 6.1 & \pm 3.0 & \pm 0.7 & \pm 2.9 & & & \\
\hline Arenas $^{236}$ & 4 & -10.75 & 2.87 & -2.37 & 3.50 & 0 & 0 & 4 \\
\hline 1997 & & NR & NR & $N R$ & NR & & & \\
\hline Wiesinger ${ }^{237}$ & 3 & -0.3 & 1.98 & 0.80 & $1.13^{*}$ & 0 & 0 & 3 \\
\hline 1998 & & \pm 2.3 & \pm 2.0 & \pm 1.4 & \pm 1.4 & & & \\
\hline Webber ${ }^{238}$ & 25 & -5.20 & 8.67 & -1.91 & 2.48 & 4 & 0 & 21 \\
\hline 1999 & & NR & NR & $N R$ & NR & & & \\
\hline Donnenfeld ${ }^{239}$ & 39 23 & -7.58 & 3.64 & -1.57 & 1.29 & 12 & 2 & 9 \\
\hline 1999 & & \pm 4.4 & \pm 1.7 & \pm 1.2 & \pm 1.0 & & & \\
\hline Guell $\left.\right|^{240}$ & $20-$ & -5.25 & NR & -0.7 & NR & NR & none & NR \\
\hline 1999 & & \pm 2.1 & $N R$ & \pm 0.7 & NR & & & \\
\hline Forseto ${ }^{241}$ & 22 & -4.55 & 4.44 & -0.67 & 1.75 & 9 & 5 & 8 \\
\hline 1999 & & \pm 3.7 & \pm 2.1 & \pm 1.2 & \pm 1.1 & & & \\
\hline Spadea $^{242}$ & 4 & -0.25 & 0.52 & -0.25 & 1.62 & 0 & 0 & 4 \\
\hline 2000 & & \pm 0.7 & \pm 5.6 & \pm 0.7 & \pm 1.7 & & & \\
\hline Koay $^{243}$ & 8 & -6.79 & 6.79 & -0.64 & 1.93 & 3 & 0 & 5 \\
\hline 2000 & & \pm 4.2 & \pm 3.3 & \pm 1.9 & \pm 1.2 & & & \\
\hline Kwitko ${ }^{244}$ & $14-$ & -5.33 & 5.37 & 0.19 & 2.82 & 9 & 0 & 5 \\
\hline 2001 & & \pm 4.2 & \pm 2.1 & \pm 1.7 & \pm 2.4 & & & \\
\hline
\end{tabular}

$\mathrm{NR}$, not reported; *, six months results; $\dagger$, two or more Snellen lines; BCVA, best corrected visual acuity.

Laser in situ keratomileusis (LASIK) may effectively reduce anisometropia and astigmatism in post-keratoplasty patients who are contact lens intolerant. The studies listed in Table 2-8 showed that best corrected visual acuity improved in $35 \%$, decreased in $8 \%$ and was unchanged in $57 \%$ of the patients. ${ }^{239,241}$ Both, spherical and cylindrical correction decreased in all patients after LASIK. ${ }^{243}$ 


\section{Chapter 2}

A new, two-step approach, in which the flap is created first and then reevaluating the refraction one-to-three months later before performing the laser ablation, may improve accuracy for an optimal visual outcome. ${ }^{245}$

\section{Contact lens fitting to improve visual performance following penetrating keratoplasty.}

Efforts to improve the refractive results after penetrating keratoplasty have included using contact lenses. ${ }^{246,247}$ The majority of patients are fitted with contact lenses when the sutures are removed (Table 2-9).

Manabe and coauthor ${ }^{248}$ were the first who described the use of the photokeratoscope to examine the entire graft topography before PMMA contact lens fitting, one month after suture removal. Several authors describe the use of the videokeratoscope in rigid gas permeable contact lens fitting following penetrating keratoplasty. Gomes ${ }^{260}$ used the corneal topography values $1.5 \mathrm{~mm}$ superior to the center of the cornea to determine the back optic zone radius (BOZR) of the initial trial lens. Lopatynsky and coauthors ${ }^{254}$ described a standard protocol for selection of the BOZR of the first trial lens by taking two successive topographical images, positioning the cursor of the videotopograph $1.5 \mathrm{~mm}$ superior to the geometric center, and calculating the average keratometry value of both images on that spot for selection of the BOZR. Fortyseven percent of the eyes in that study were dispensed with an initial trial lens BOZR. Sperber and coauthors ${ }^{258}$ used the same technique. Within one year, 11 of the 23 eyes needed one or more refits.

Szczotka and coauthors ${ }^{259}$ successfully used the custom design contact lens computer program of the TMS-1 corneal topographer to fit both eyes of one patient following keratoplasty. The attempted lens BOZR to cornea relationship was that which provided minimal surface bearing yet adequate corneal clearance to provide sufficient tear exchange and prevent bubble formation. Contact lenses with an overall diameter of $8.6 \mathrm{~mm}$ were used in the study.

A longitudinal study done by Genvert and coauthors ${ }^{249}$ included 74 eyes with a mean contact lens wear of 14 months; allograft rejection episodes occurred in $5 \%$ of the eyes wearing polyvinyl methacrylate (PMMA) contact lenses. Twelve percent of eyes developed contact lens intolerance. 
Table 2-9 RGP Contact lens fitting following penetrating keratoplasty.

\begin{tabular}{|c|c|c|c|c|c|c|c|c|}
\hline Author & Year & No & $\begin{array}{l}\text { Months after } \\
\text { keratoplasty }\end{array}$ & $\begin{array}{l}\text { Sutures } \\
\text { in/out }\end{array}$ & $\begin{array}{l}\text { s Type of } \\
\text { lens fitted }\end{array}$ & $\begin{array}{l}\text { Technique } \\
\text { described }\end{array}$ & $\begin{array}{l}\text { Diameter } \\
(\mathrm{mm})\end{array}$ & $\begin{array}{l}\text { Rejection } \\
(\%)\end{array}$ \\
\hline Genvert $^{249}$ & 3985 & 74 & $12-18$ & out & RGP & flat $\mathrm{K}$ & $8.5-10.0$ & 5.4 \\
\hline Speaker $^{250}$ & 1991 & 8 & $14-36$ & out & RGP & flat $K$ & $8.5-9.6$ & 27.8 \\
\hline Smiddy ${ }^{251}$ & 1992 & 16 & 21 & $3 / 16$ in & RGP & flat $\mathrm{K}$ & NR & 10.0 \\
\hline Wilson ${ }^{252}$ & 1992 & 5 & $3-6$ & out & \multicolumn{3}{|c|}{ RGP concentric to graft 10.0} & $\mathrm{NR}$ \\
\hline Weiner ${ }^{253}$ & 1992 & 32 & $3-60$ & $5 / 32$ in & RGP & flat K & $8.6-10.5$ & 3.1 \\
\hline Lopatynsky ${ }^{254}$ & 1993 & 19 & 56 & $4 / 56$ in & RGP & topography & 9.1 & NR \\
\hline Davis $^{255}$ & 1994 & 5 & NR & out & RGPEW & trial & 10.0 & NR \\
\hline Koffler ${ }^{256}$ & 1994 & 28 & $>30$ & $9 / 28$ in & RGP & trail & 9.5 & NR \\
\hline Bourne $^{257}$ & 1995 & 15 & $3-24$ & out & RGP & NR & NR & NR \\
\hline Sperber $^{258}$ & 1995 & 23 & $>20$ & $8 / 23$ in & RGP & \multicolumn{2}{|c|}{ topography 9.3} & NR \\
\hline Szczotka ${ }^{259}$ & 1995 & 2 & 240 & out & RGP & \multicolumn{2}{|c|}{ topography 8.6} & 0 \\
\hline Gomes $^{260}$ & 1996 & 18 & 35 & in & RGP & \multicolumn{2}{|c|}{ topography NR } & NR \\
\hline $\operatorname{Lim}^{261}$ & 2000 & 4 & NR & out & RGM & trail & 9.53 & NR \\
\hline
\end{tabular}

NR, not reported; RGP, rigid gas permeable; RGPEW, rigid gas permeable extended wear. RGM, reversed geometry lens.

Subsequent studies of Gomes and coauthors ${ }^{260}$ conclude that it is safe to fit eyes with RGP contact lenses following penetrating keratoplasty and that the corneal topography remains stable for 30 months after contact lens wear even with the sutures in place.

Smiddy and coauthors ${ }^{262}$ found that the use of RGP contact lenses did not preclude the use of chronic postoperative topical medications, nor did it increase the risk of corneal graft rejection. He also found that contact lenses may be useful for optimizing vision after penetrating keratoplasty.

In penetrating keratoplasty the success depends primarily on the viability of the endothelium. The mean rate of late endothelial cell loss in non contact lens wearing eyes from 5 to 10 years post-keratoplasty was found to be $4.2 \%$ per year. ${ }^{263}$ Bourne $\mathrm{e}^{257}$ found no significant difference in endothelial cell density count 10 years after penetrating keratoplasty in patients wearing daily rigid gas 
permeable contact lenses and controls. Both groups had lost $73 \%$ of endothelial cells, 10 years following penetrating keratoplasty. In contrary in patients wearing PMMA (non-oxygen permeable) contact lenses for five years, Matsuda and coauthors ${ }^{264}$ noticed an endothelial cell loss of $20.9 \%$ compared to controls (884 \pm 85 vs $1,117 \pm 86$ cells $/ \mathrm{mm}^{2}$ ). He showed that the use of RGP contact lenses following penetrating keratoplasty might prevent morphologic changes of the cornea endothelium.

Many different rigid gas permeable contact lens designs are used for the correction of astigmatism and anisometropia after penetrating keratoplasty. Koffler and coauthors ${ }^{256}$ successfully used the Quintasphere Penetrating Keratoplasty (R\&D Ophthalmic, Mansfield, $\mathrm{OH}$ ) rigid gas permeable contact lens in $93 \%$ of the patients fit with contact lenses. This lens has a back optic zone diameter (BOZD) of $7.9 \mathrm{~mm}$ and a total diameter of $9.5 \mathrm{~mm}$. The peripheral curves are $0.8 / 1.6 / 3.0 / 5.5 \mathrm{~mm}$ flatter than the back optic zone radius (BOZR) and were fitted using the fluorescein pattern vaulting at the graft site with peripheral bearing. Weiner and coauthors ${ }^{253}$ successfully used the Boston Envision (Polymer Technology, Wilmington, MA) bi-aspheric design in $81 \%$ of the patients. They were the first to mention the contact lens fitting criteria: patients were referred for fitting when it was determined that the cornea was sufficiently healed and could support a contact lens.

In some cases reversed geometry contact lenses are preferred. Lim and coauthors ${ }^{261}$ described the use of the Plateau lens (Menicon Inc, Clovis, CA) in fitting four eyes of penetrating keratoplasty patients. He used the mid-peripheral zone on the topographic map for selection of the base curve (BC) (in case of reverse geometry is that the second curve), and the fluorescein pattern to refine the lens fitting. The difference between the base curve and the BOZR varied from two to ten diopters; small differences between $B C$ and BOZR reduced peripheral bearing, allowed more tear flow, increased lens movement, and helped low riding lenses to center better.

Even hybride lenses (SoftPerm ${ }^{\circledR}$, Januslens ${ }^{\circledR}$ and others) have been used by Binder and coauthors ${ }^{265}$, but a separation or tearing often occurred at the bonded junction, which accounted for the majority of failures. Only $45 \%$ of patients continued to wear the lens nine months after fitting.

Wilson and coauthors ${ }^{252}$ used a contact lens as a splint or mold in five eyes. He removed all sutures 3 months after surgery and fit rigid gas permeable contact lenses. The anterior corneal surface showed improvement of the surface regularity index (Topographic Modeling System 1, Tomey Technology), from $4.7 \pm 0.6$ before contact lens fitting to $1.8 \pm 0.8$ after fitting. 


\section{Review of the literature}

Davis $^{255}$ showed that rigid gas permeable contact lens wear on extended wear basis was not successful. In a study of five patient eyes, only one eye could wear the lens for 15 months.

In chapter 3 the safety and efficacy of a new contact lens fitting technique in patients following penetraling keratoplasty is described. 


\subsection{CORNEAL EXCIMER LASER SURGERY}

Photoablation with the excimer laser (excimer is the abbreviation for excited dimer) occurs with the 193-nm photon in the far ultraviolet spectrum, having sufficient energy to directly break carbon-carbon and carbon-nitrogen bonds that form the peptide backbone of the corneal collagen molecules. The excimer laser has demonstrated the ability to treat anterior opacities and irregularities of the cornea with submicron precision without significant injury to nonablated tissue. ${ }^{266.267}$

The excimer laser can be used for reshaping the corneal curvature, for controlled removal of corneal tissue, and in reconstructive superficial keratectomy. The use of the Argon Fluoride excimer laser to treat superficial corneal diseases and smooth corneal surface irregularities is called phototherapeutic keratectomy. When tissue molecules dissociate, they emit high-energy UV light and the energy of the photons emitted is greater than the energy required, thus it breaks organic intermolecular bonds. This process is called ablative photodecomposition. ${ }^{268}$

\section{Phototherapeutic Keratectomy (PTK)}

In 1988, investigational protocols began to determine the efficacy of PTK in humans. ${ }^{269}$ The unprecedented ability to ablate corneal tissue without damage to adjacent, untreated tissue provides the corneal surgeon with a powerful tool in the treatment of anterior corneal diseases and corneal irregularities.

Indications for PTK include anterior basement membrane dystrophy, dystrophies of Bowman's membrane, such as Reis Bückler, and dystrophies of the superficial stromal, including lattice, Schnyder's and granular dystrophy, The Reis-Bückler and granular hereditary pattern are autosomal dominant. ${ }^{271,271,272}$ Molecular biologic investigation has shown that ReisBückler, granular, and lattice type-I dystrophies share the same genetic locus on chromosome $5 \mathrm{q} 311^{273,274}$ The molecular genetics of these and other corneal dystrophies has been well summarized recently by Klintworth. ${ }^{275}$

Anterior membrane dystrophies are characteristically symptomatic, with painful recurrent corneal erosions, which result from abnormalities of the epithelium, the corneal basement membrane, or Bowmans' layer. ${ }^{276}$ Disorders limited to the superficial stromal layers may be managed with phototherapeutic keratectomy. ${ }^{277}$ Consequently, lamellar- or penetrating keratoplasty may be avoided in these cases. ${ }^{278}$ PTK involves surgery of only the superficial cornea, 
Review of the literature

Table 2-10 Phototherapeutic keratectomy of anterior dystrophies.

\begin{tabular}{|c|c|c|c|c|c|c|c|}
\hline Author & $\begin{array}{l}\text { Year } \\
\text { of }\end{array}$ & $\begin{array}{l}\text { Type } \\
\text { dystrophy }\end{array}$ & $\begin{array}{l}\text { No } \mathrm{Ab} \\
\text { of eyes }\end{array}$ & $\begin{array}{l}\text { dblation depth } \\
(\mu \mathrm{m})\end{array}$ & $\begin{array}{l}\text { Refractive } s \\
\text { mean } \pm S D\end{array}$ & $\begin{array}{l}\text { ift in D } \\
\text { pre PTK }\end{array}$ & $\begin{array}{l}\text { BCVA, mean } \\
\text { / post PTK }\end{array}$ \\
\hline McDonnell $^{279}$ & 1992 & $\mathrm{RB}$ & 2 & 384 & $+6.8 \pm \mathrm{NR}$ & $20 / 100$ & $20 / 25$ \\
\hline Rogers 280 & 1993 & $\mathrm{RB}$ & 11 & 43 & $+3.09 \pm N R$ & NR & NR \\
\hline Lawless $^{281}$ & 1993 & $\mathrm{RB}$ & 9 & 117 & $+2.75 \pm N R$ & $20 / 160$ & $20 / 32$ \\
\hline $\operatorname{Hersh}^{282}$ & 1993 & $\mathrm{RB}$ & 2 & $264^{*}$ & $+1.6 \pm \mathrm{NR}$ & $20 / 63$ & $20 / 32$ \\
\hline Poirier $^{283}$ & 1994 & RB & 2 & NR & $+2.6 \pm N R$ & $20 / 50$ & $20 / 32$ \\
\hline Heinz $^{284}$ & 1995 & GD & 3 & 35 & $+0.6 \pm 0.4$ & $20 / 63$ & $20 / 25$ \\
\hline \multirow[t]{2}{*}{ Maloney $^{285}$} & 1996 & $\mathrm{RB}$ & 4 & $160^{*}$ & $+0.87 \pm \mathrm{NR}$ & $20 / 50$ & $20 / 32$ \\
\hline & & GD & 8 & $160^{*}$ & $+0.87 \pm \mathrm{NR}$ & $20 / 50$ & $20 / 32$ \\
\hline Nassaralla ${ }^{286}$ & 1996 & GD & 2 & 110 & $-1.0 \pm \mathrm{NR}$ & NR & NR \\
\hline \multirow[t]{2}{*}{ Örndaht ${ }^{287}$} & 1998 & GD & 5 & 48 & $+4.65 \pm 2.2$ & $20 / 160$ & $20 / 50$ \\
\hline & & $\mathrm{RB}$ & 2 & 40 & $+1.87 \pm 1.8$ & $20 / 63$ & $20 / 20$ \\
\hline Aouni $^{288}$ & 1998 & RB & 10 & NR & $+2.5 \pm \mathrm{NR}$ & $20 / 63$ & $20 / 32$ \\
\hline$A_{\text {mano }}{ }^{289}$ & 1999 & GD & 10 & NR & $+0.75 \pm N R$ & $20 / 125$ & $20 / 40$ \\
\hline \multirow[t]{2}{*}{$\operatorname{Dinh}^{290}$} & 1999 & $\mathrm{RB}$ & 13 & $N R$ & NR & NR & NR \\
\hline & & GD & 11 & NR & NR & NR & NR \\
\hline Dighiero $^{291}$ & 1999 & GD & 27 & $<125$ & $+2.8 \pm \mathrm{NR}$ & $20 / 100$ & $20 / 32$ \\
\hline Kasetsuwan ${ }^{292}$ & 2000 & RB & 4 & 75 & $+3.5 \pm \mathrm{NR}$ & $20 / 100$ & $20 / 32$ \\
\hline
\end{tabular}

NR, not reported; BCVA, best corrected visual acuity; RB Reis Buckler; GD granular dystrophy; *, smoothing technique used. During the smoothing technique, modulating agents are used to cover irregular areas, and by evaporation take a part of the laser energy.

causing less operative risk than conventional keratoplasty, and improves visual acuity in patients with visual loss from corneal opacities. Histologic specimens 
of PTK-treated corneas show a smooth boundary between ablated and nonablated tissue. ${ }^{293,294}$ Phototherapeutic keratectomy is not suitable for disorders with variable corneal thickness or deep stromal opacities. ${ }^{295}$ The smooth soft contour of the remaining anterior stromal tissue following PTK, provides patients with an increased visual acuity after PTK. Six months postoperative, all patients mentioned in Table 2-10, achieved substantial improvement in visual acuity, resulting in a visual acuity of at least 20/40 or better, and all Reis-Bückler patients had complete cessation of recurrent erosions. Amm and coauthors ${ }^{296}$ showed that after PTK, all types of refractive change might occur (Table 2-10; range -1.0 to $+6.8 \mathrm{D}$ ). The greatest risk is a hyperopic shift that may be correlated with the ablation depth. Excision of anterior superficial corneal opacities with excimer laser was able to delay the need for keratoplasty surgery in all patients. When patients experience a decrease of visual acuity, PTK is now the most common therapy for these types of dystrophies. Dingh and coauthors ${ }^{290}$ demonstrated a recurrence of the disease in $36.6 \%$ of the patients, 40.3 months after PTK.

Following PTK, McDonnell ${ }^{279}$ successfully fit a soft contact lens to correct the anisometropia which caused a hyperopic shift in one patient. RGP contact lens fitting after PTK is only described in keratoconus patients treated for nodular subepithelial corneal scars. ${ }^{297}$

Chapter 5 evaluates the efficacy of a contact lens fitting technique in a patient with gramular dystrophy after PTK treatment.

Chapter 6 evaluates the visual acuity results six months after PTK treatment, with and without contact lenses wear in a family with a Reis Bückler dystrophy.

\section{Refractive surgery with the excimer laser}

The aspherical shape of the refracting surfaces (i.e. cornea and lens) of the human eye acts to minimize the potentially large optical aberration that would otherwise affect the retinal image produced by such a powerful optical system. The overall refractive power of the eye is in the order of $+58 \mathrm{D}$, with the front corneal surface contributing about $+43 \mathrm{D}^{2}$ or approximately $75 \%$ of the total. As stated above, the cornea is therefore one of the main candidates for alteration in refractive surgical procedures, since relatively small curvature changes result in relatively large changes in refractive status. Especially in the last two decades, refractive corneal surgery became very popular and developed into a subspecialty within ophthalmology. ${ }^{298}$ 


\section{Photorefractive keratectomy}

Photorefractive Keratectomy (PRK) is a technique in which the corneal profile is flattened by the excimer laser. The first one who used the excimer laser irradiation to produce corneal tissue removal was Trokel. ${ }^{299}$ Marshall reprofiled the cornea by removing a disc of tissue. ${ }^{300}$

The procedure received Food and Drug Administration (FDA) pre-market approval in the fall of 1995 to treat myopia, and in early 1998 to treat astigmatism. ${ }^{301}$

The first excimer laser devices had a delivery system with a large circular beam of $5.0 \mathrm{~mm}$, which was modified with a diaphragm in order to deliver more cumulative energy in the center and less in the periphery, creating corneal flattening. The general Munnerlyn formula used to estimate the amount of tissue to be removed centrally is: ${ }^{302}$

(ablation diameter $(\mathrm{mm}))^{2} \times$ diopters $(\mathrm{D})$

Ablation depth (microns) $=$

3

Both hardware and software are still undergoing technical adjustments, and the surgical technique and postoperative care for the myopic patient are still being refined.

Multizone techniques were designed to reduce the depth of the ablation while maintaining a large total ablation zone. In multipass techniques, treatment is divided into segments that may yield a smoother ablation bed and better clinical results. ${ }^{303}$ The latest refinements include the development of flying spot lasers with spot sizes of $1.0 \mathrm{~mm}$, reducing the central island formation, and automatic tracking systems ${ }^{304}$ that reduce alignment errors. The size of the ablation zone depends on many factors, including pupil size, and the degree of myopia to be corrected and the need to minimize glare, but the surgeon must also consider that larger ablation zones require greater epithelial removal. Reepithelialization of the defect is usually completed within 3-4 days. ${ }^{305}$ 


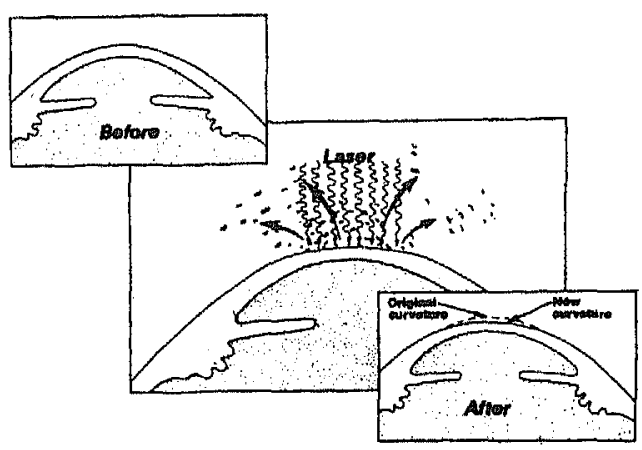

Figure 2-6. Schematic representation of the process of flattening the cornea with excimer laser wide-area photorefractive keratectomy. (figure: Geertjan van Zonneveld)

PRK is now considered by many ophthalmologists to be reasonably safe and effective, and has become a common technique for the treatment of low to moderate myopia worldwide, with more predictable and stable results than radial keratotomy. ${ }^{306,307}$

\section{Laser in situ Keratomileusis}

Laser in situ keratomileusis (LASIK) combines lamellar corneal surgery with the accuracy of the excimer laser. Pallikaris performed the first LASIK procedure on a human eye in $1990{ }^{308}$ The term keratomileusis is derived from the Greek "to modulate the cornea".

The surgeon uses an automated microkeratome to create a corneal lamellar flap, lift the flap and ablate stromal tissue from the lamellar bed with the excimer laser, and return the flap to its place. (Figure 2-7)

The natural dehydration created by the endothelial 'pump' in combination with the natural pressure of the atmosphere is adequate to hold the flap in place without sutures.

To reduce pain and assist in epithelial corneal healing, in some patients a soft disposable contact lens is placed on the eye after the procedure. It usually remains for two to four days ${ }^{309}$ Topical antibiotics, and non-steroidal antiinflammatory drugs (NSAIDs) ${ }^{310}$ are prescribed following treatment. 

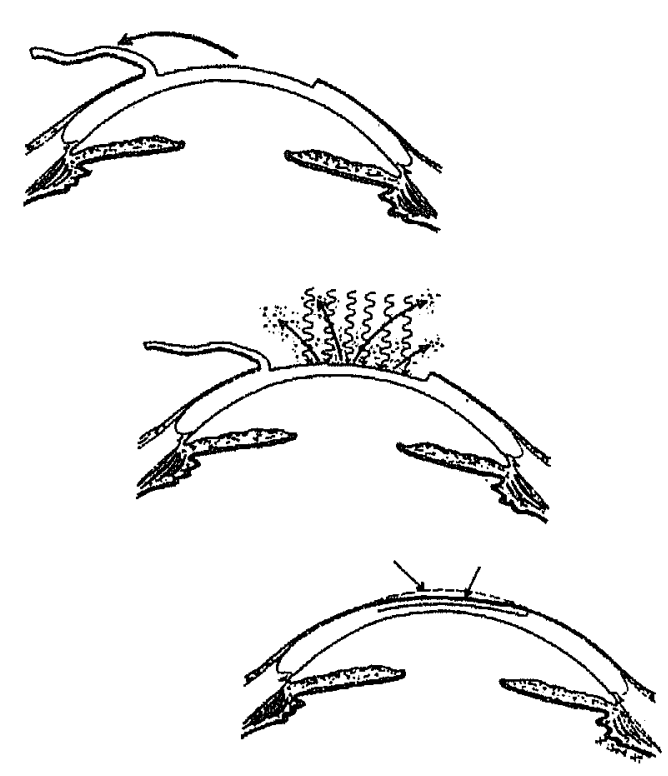

Figure 2-7. Schematic representation of the laser in situ keratomileusis procedure to flatten the central cornea for the correction of myopia. (figure: Geertjan van Zonneveld)

\section{New techniques}

Many of the newest technological developments in PRK and LASIK, including flying spot lasers with tracking mechanisms, are more accurate and efficient. In addition, the software for flying-spot lasers can be modified to generate various ablation shapes, even irregular ones. ${ }^{311,312}$ Recently, advanced mathematics as well as ray tracing are used in analysis, ${ }^{313}$ which provide new dimensions of information through ray tracing of images which pass through the cornea and predict the quality of the image imposed on the retina around the fovea. A future combination of tracking assisted ablation with customized ablation that bases ablation on retinal image distortion will probably account for less induced optical aberrations and result in even more accurate excimer laser corrections.

\section{Reporting refractive surgical data results}

When presenting refractive surgical data, we strive for $20 / 20$ uncorrected acuity as an appropriate end point after surgery. ${ }^{314}$ It is not that long ago, in fact, 
that we were happy with 20/40 unaided and \pm 1.0 diopter as an appropriate end point after refractive surgery. Until now we measure psychophysically visual acuity and not visual quality, using objective tests that we perform, which elicit information from the patient. The psychophysical tests are subject to bias by the surgeon or examiner. ${ }^{315}$ Patients and surgeons are interested in basic elements as uncorrected visual acuity (UCVA), loss of best spectacle-corrected visual acuity (BSCVA), and the calculation of the surgically induced change. The minimal follow-up after refractive surgery procedures should be six months. In photorefractive keratectomy, most papers present 12 months follow-up data, and in LASIK 6 months data, this is because a refractive stable result is attained sooner after LASIK.

When reporting data, a preoperative classification of the refractive error may be used: ${ }^{316}$ low (1.00 to $\left.3.99 \mathrm{D}\right)$; moderate (4.00 to $\left.5.99 \mathrm{D}\right)$; high ( 6.00 to $9.99 \mathrm{D})$; extreme (10.00 to $30.00 \mathrm{D})$. The number of eyes in each group has to be given.

\section{Safety}

Number and percentage of eyes losing two or more lines of best spectaclecorrected visual acuity (BSCVA) is considered to be a significant loss and is a measure of safety of the procedure. The number $(\%)$ of eyes with significant loss must be mentioned. The safety index is the ratio of mean postoperative BSCVA over mean preoperative BSCVA (i.e., [mean postop BSCVA]/[mean preop BSCVA]). This is most easily calculated by converting the values of geometric mean acuity's to LogMAR values. In early PRK studies, a loss of two or more lines of BCVA was found in $0.27 \%{ }^{317,318}$ to $3.4 \%{ }^{319}$ of the patients. Recent PRK results are reported in Table 2-11 and LASIK results are reported in Table $2-12$.

\section{Efficacy}

The efficacy addresses the postoperative state of the patient. Percentage of eyes with uncorrected visual acuity of 20/40 and 20/20 should be mentioned. Efficacy index is the ratio of the mean postoperative uncorrected visual acuity (UCVA) to the mean preoperative BSCVA (i.e., [mean postop UCVA]/[mean preop BSCVA]). This is most easily calculated by converting the values of geometric mean acuity's to decimal values. This measure is particularly useful in describing outcomes of patients with high myopia when the preoperative BSCVA is worse than 20/20. 


\section{Predictability}

Predictability of results refers to the accuracy of the treatment method, and hence the ability to successfully predict the outcome of treatment. Mean, standard deviation, and range of postoperative spherical equivalent should be mentioned. A tabular display of the number and percentage of eyes in various categories, for example, the number of eyes (\%) which achieved a spherical equivalent within $\pm 1.00 \mathrm{D}$ and $\pm 0.50 \mathrm{D}$ of desired postoperative refractive error may be given. ${ }^{320}$ Information may be given of the number and percentage of eyes that achieved an over-correction by $1.00 \mathrm{D}$ or more. ${ }^{321}$ The spherical equivalent is followed over a period of at least 6 months. A change of one diopter or more is considered to be clinically significant in stability of the result.

Astigmatic correction, mean, standard deviation, and range of postoperative astigmatism clearly defined as refractive, keratometric, or derived by computerized videokeratography should be mentioned. Surgically induced astigmatism may be calculated by vector analysis ${ }^{322}$ More advanced astigmatic analyses is described by Alpins and coauthors, ${ }^{323,324,32.5}$ using vector analysis to generate the surgical induced astigmatic change for every single patient. Holladay and coauthors, ${ }^{326,327}$ converted cylinder magnitude and axis to $x$ and $y$ Cartesian values which are displayed using double-angle plots. They calculated the defocus equivalent as an index that reflects the impact of residual spherical and cylindrical error on uncorrected visual acuity. Thibos and coauthors ${ }^{328}$ separated the refractive data into 3 power vectors: spherical equivalent and 2 Jackson crossed cylinders separated by 45 degrees. Naeser ${ }^{329}$ and Hjortdal ${ }^{330}$ used polar analysis and, in a method that is analogous to Thibos' approach, characterize any astigmatic value by 2 polar values that are separated by 45 degrees.

\section{Stability}

The number and percentage of eyes with a change in spherical equivalent of manifest refraction of $1.00 \mathrm{D}$ or more within a specified interval is considered to be clinically significant and should be mentioned. The recommended minimal interval between the two measurements is 6 months. Data could be expressed in a figure or table showing spherical equivalent of manifest refraction plotted against time for the same cohort of patients followed throughout the postoperative period. 


\section{Chapter 2}

\section{Photorefractive keratectomy results}

One year after PRK, the percentage of eyes with a spherical equivalent of $\pm 1.00 \mathrm{D}$ and $\pm 0.50 \mathrm{D}$ varied from 86 to $94 \%{ }^{335,331}$ and from 61 to $83 \%$ respectively (Table 2-11). ${ }^{331,337}$ The percentage of eyes with an UCVA of $\geq 20 / 40$ and $\geq 20 / 20$ varied from 83 to $98 \%{ }^{331,337}$ and from 39 to $90 \%$ respectively. ${ }^{333,332}$ Loss of two or more lines of BCVA varied from 0 to 4 $\%{ }^{335,331}$

Table 2-11 One year photorefractive keratectomy results.

\begin{tabular}{|c|c|c|c|c|c|c|c|}
\hline $\begin{array}{l}\text { Author } \\
\text { Year }\end{array}$ & $\begin{array}{l}\text { No } \\
\text { of eye }\end{array}$ & $\begin{array}{l}S E \text {, preop } S E, p \\
\text { mean } \pm S D \text { mean } \\
\text { (range) (rang }\end{array}$ & $\begin{array}{l}\text { postoperative } \\
\text { In } \pm \text { SD } \pm 1.0 \\
\text { ge) } \quad \%\end{array}$ & $\begin{array}{l}00 \mathrm{D} / \pm 0.50 \mathrm{D} \\
\% \text { of eyes }\end{array}$ & $\begin{array}{l}\text { UCVA, } \\
\text { postop, } \% \\
\geq 20 / 40 / \geq 20 /\end{array}$ & $\begin{array}{l}\text { Loss BCVA } \\
\geq 2 \text { lines } \\
0 / 20\end{array}$ & $\begin{array}{l}\text { A No } \\
\text { retreat }\end{array}$ \\
\hline Wang $^{331}$ & 307 & NR & NR & $94 / 61$ & $83 / 72$ & $4 \%$ & 0 \\
\hline 1997 & & $(-1.25$ to -6.00$)$ & NR & & & & \\
\hline Shah $^{332}$ & 3218 & $-3.75 \pm 1.7$ & $-0.07 \pm 0.68$ & $90 / 73$ & $94 / 90$ & $0.9 \%$ & 164 \\
\hline 1998 & & $(-1.0$ to -11.0$)$ & $(-5.5$ to 4.5$)$ & & & & \\
\hline Pietila $^{333}$ & 226 & $-4.10 \pm 1.20$ & NR & $87 / 68$ & $88 / 39$ & $1.4 \%$ & NR \\
\hline 1998 & & $(-1.25$ to -6.0$)$ & NR & & & & \\
\hline Hadden $^{334}$ & 192 & $-7.68 \mathrm{NR}$ & NR & $94 / 77$ & $94 / 59$ & $1.2 \%$ & NR \\
\hline 1999 & & $(-6.0$ to -10.0$)$ & NR & & & & \\
\hline $\mathrm{Ahn}^{335}$ & 87 & $-5.14 \pm 1.78$ & $-0.33 \pm 0.73$ & $86 / 67$ & $91 / 48$ & $0 \%$ & 1 \\
\hline 1999 & & $(-1.75$ to -8.25$)$ & NR & & & & \\
\hline Kapadia $^{336}$ & 236 & $\mathrm{NR}$ & $-0.3 \pm 0.8$ & $92 / 73$ & $97 / N R$ & $0.4 \%$ & 22 \\
\hline 2000 & & $(-1.0$ to -6.0$)$ & NR & & & & \\
\hline Pop $^{337}$ & 107 & $-5.55 \pm 2.21$ & NR & $94 / 83$ & $98 / 86$ & $0 \%$ & 10 \\
\hline 2000 & & $(-1.0$ to -9.5$)$ & NR & & & & \\
\hline
\end{tabular}

$\mathrm{NR}$, not reported; SE, spherical equivalent; UCVA, uncorrected visual acuity; BCVA, best corrected visual acuity. 


\section{Laser in situ keratomileusis results}

Six months after LASIK the percentage of eyes with a spherical equivalent of $\pm 1.00 \mathrm{D}$ and $\pm 0.50 \mathrm{D}$ varied from 63 to $100 \%{ }^{342,346}$ and from 53 to $94 \%$ respectively (Table 2-12). ${ }^{339,345}$ The percentage of eyes with an UCVA of $\geq 20 / 40$ and $\geq 20 / 20$ varied from 76 to $100 \%{ }^{339,341}$ and from 12 to $81 \%$ respectively. ${ }^{342,345}$ Loss of two or more lines of BCVA varied from 0 to 9.7 $\%$

Table 2-12 6 months results after LASIK treatment for myopia.

\begin{tabular}{|c|c|c|c|c|c|c|c|}
\hline $\begin{array}{l}\text { Author } \\
\text { Year }\end{array}$ & $\begin{array}{l}\text { No } \\
\text { of } \\
\text { eyes }\end{array}$ & $\begin{array}{l}S E \text {, preop } \\
\text { mean } \pm S D \\
\text { (range) }\end{array}$ & $\begin{array}{l}\text { SE, postop } \\
\text { mean } \pm \mathrm{SD} \\
\text { (range) }\end{array}$ & $\begin{array}{c} \pm 1.0 \mathrm{D} / \pm 0.5 \mathrm{D} \\
\% \text { of eyes }\end{array}$ & $\begin{array}{l}\text { UCVA } \\
\% \text { of eye } \\
\geq 20 / 40 / \geq\end{array}$ & $\begin{array}{l}\text { Loss BCVA } \\
s \geq 2 \text { lines } \\
20 / 20\end{array}$ & $\begin{array}{l}\text { No } \\
\text { retreat }\end{array}$ \\
\hline $\begin{array}{l}\text { Pirzada }{ }^{338} \\
1997\end{array}$ & 85 & $\begin{array}{l}-2.09 \mathrm{NR} \\
(-1.0 \text { to }-3.5)\end{array}$ & $\begin{array}{l}\text { NR } \\
\text { NR }\end{array}$ & NR & $93 / \mathrm{NR}$ & $1 \%$ & 0 \\
\hline $\begin{array}{l}\text { Zaldivar }^{339} \\
1997\end{array}$ & 83 & $\begin{array}{l}-3.54 \pm 1.41 \\
(-1.13 \text { to }-7.25)\end{array}$ & $\begin{array}{l}-0.65 \pm 0.62 \\
\mathrm{NR}\end{array}$ & $81 / 53$ & $76 / 28$ & $0 \%$ & 0 \\
\hline $\begin{array}{l}\text { Zaldivar }^{340} \\
1998\end{array}$ & 84 & $\begin{array}{l}-8.62 \pm 1.27 \\
(-5.5 \text { to }-11.50)\end{array}$ & $\begin{array}{l}-0.61 \pm 0.84 \\
(+0.5 \text { to }-1.50)\end{array}$ & $83 / 53$ & $77 / 28$ & $1.2 \%$ & 9 \\
\hline $\begin{array}{l}\text { Salchow }{ }^{341} \\
1998\end{array}$ & 62 & $\begin{array}{l}-6.1 \pm 3.12 \\
(-1.0 \text { to }-13.25)\end{array}$ & $\begin{array}{l}+0.04 \pm 0.66 \\
(+2.0 \text { to }-1.75)\end{array}$ & $94 / 77$ & $100 / 43$ & $9.7 \%$ & 1 \\
\hline $\begin{array}{l}\text { Maldonado } \\
1998\end{array}$ & 42138 & $\begin{array}{l}-8.33 \pm 1.24 \\
(-6.25 \text { to }-10.0)\end{array}$ & $\begin{array}{l}-0.19 \pm 1.22 \\
(+3.0 \text { to }-3.0)\end{array}$ & $63 / N R$ & $95 / 12$ & $3.1 \%$ & $N R$ \\
\hline $\begin{array}{l}\text { Dulaney }{ }^{343} \\
1998\end{array}$ & 89 & $\begin{array}{l}-4.81 \pm 2.21 \\
(-1.35 \text { to }-10.0)\end{array}$ & $\begin{array}{l}-0.35 \pm 0.77 \\
(+1.5 \text { to }-1.5)\end{array}$ & $83 / 81$ & $91 / 56$ & $0 \%$ & 3 \\
\hline $\begin{array}{l}\text { Carr }^{3 / 4} \\
1998\end{array}$ & 190 & $\begin{array}{l}-5.17 \pm 1.4 \\
(-2.25 \text { to }-7.8)\end{array}$ & $\begin{array}{l}-0.84 \pm 0.65 \\
(+1.0 \text { to }-1.25)\end{array}$ & NR & $N R$ & NR & $\mathrm{NR}$ \\
\hline $\begin{array}{l}\text { Montes } \\
1999\end{array}$ & 168 & $\begin{array}{l}-3.6 \pm 1.27 \\
(-1.5 \text { to }-6.0)\end{array}$ & $\begin{array}{l}-0.12 \pm 0.31 \\
(+0.5 \text { to }-1.0)\end{array}$ & $100 / 94$ & $100 / 81$ & $0 \%$ & 9 \\
\hline $\begin{array}{l}\text { Reviglio }^{346} \\
1999\end{array}$ & 223 & $\begin{array}{l}-2.90 \pm 0.56 \\
(-1.0 \text { to }-3.99)\end{array}$ & $\begin{array}{l}-0.41 \pm 0.5 \\
\text { NR }\end{array}$ & $100 / 90$ & $96 / 54$ & $0 \%$ & 2 \\
\hline $\begin{array}{l}\text { Gimbel }^{347} \\
1999\end{array}$ & 289 & $\begin{array}{l}-8.4 \pm 2.73 \\
(-2.63 \text { to }-16.0)\end{array}$ & $\begin{array}{l}-0.65 \pm 0.70 \\
(+1.38 \text { to }-4.63)\end{array}$ & $80 / 57$ & $85 / 50$ & $2.7 \%$ & 3 \\
\hline
\end{tabular}

NR not reported; SE, spherical equivalent; UCVA, uncorrected visual acuity; BCVA, best corrected visual acuity. 


\section{Chapter 2}

Most studies involving LASIK have treated patients with moderate to high myopia ${ }^{348,349}$ making it difficult to compare LASIK with other refractive surgery procedures for low to moderate myopia. In studies directly comparing LASIK with PRK, LASIK was found more predictable and stable than PRK. ${ }^{350}$ Because the studies in Tables 2-11 and 2-12 contain eyes from a heterogeneous population, it is difficult to make generalizations regarding best spectacle corrected visual acuity. Improvement in BCVA following refractive surgery is likely due to a reduction of the myopia and the result of an enlarged retinal image. ${ }^{351}$

\section{Complications of excimer laser refractive surgery}

Causes of decreased BSCVA included corneal haze, central islands, regression, postoperative multifocality (possibly from decentered ablation zones), optical aberrations, and flap related problems in LASIK. Corneal topography was developed as a way to measure the shape of the cornea after refractive surgery in order to understand patients' visual complaints and ultimately the optical performance of the cornea after refractive procedures.

Haze

Within 3 to 12 weeks after PRK, most patients develop detectable haze, probably triggered by programmed cell death (apoptosis) during wound healing. ${ }^{352,353}$ Severe haze can attribute to extracellular matrix deposition or epithelial hyperplasia which may result in curvature regression and decreased uncorrected and best corrected visual acuity. ${ }^{354}$ The haze grading $(0-5)$ is from clear to unable to view anterior chamber. Reports indicate that it typically reaches trace haze or +1 levels, stabilizes, and then subsides and often disappears. ${ }^{355}$ Significant corneal haze (grade $\geq 2$ ) may be found in greater power change in combination with large optical zone diameters (the greater the excision depth of stromal tissue).The number of patients with significant corneal haze varies from 1.8 to $26 \%{ }^{356,357}$

\section{Central islands}

The exact definition of the term 'central island' varies in the literature, but common definition is a topographic area at least $1.5 \mathrm{~mm}$ in diameter and at least 3D steeper than the surrounding zone. ${ }^{358}$

Central islands are a complication of PRK and LASIK. Central islands may be caused by a partial absorption of the incoming laser light by the plume 
(debris) from the previous laser pulses. ${ }^{359}$ It also may be due to the laser shock wave redistributing fluid centrally, ${ }^{360}$ partially impeding central ablation. The reported incidence varies considerably from $26 \%$ after $\mathrm{PRK}^{361}$ to $5 \%$ after LASIK. ${ }^{362}$ Central islands cause numerous detrimental visual effects such as undercorrection, irregular astigmatism, delayed visual rehabilitation, reduced BSCVA, monocular diplopia and ghosting. Lin $^{383}$ found central islands in $26 \%$ of eyes one month following surgery but only in $2 \%$ of the eyes one-year after treatment. Central islands that do not resolve with time and that have a stable topography may be corrected safely with another excimer laser treatment with adjustable transition zones. However, poor predictability of the refractive effect of the central re-ablation may limit this treatment modality. ${ }^{363}$

\section{Overcorrection}

Overcorrection is defined as a residual deviation of more than $+1.0 \mathrm{D}$ from the intended final refraction. Vaipayee and coauthors ${ }^{364}$ found an overcorrection in $2.2 \%$ of patients. Seiler and coauthors ${ }^{319}$ noted an overcorrection in less than $1 \%$ of their patients. The occurrence of overcorrection was significantly related to the amount of attempted refractive correction i.e. patients treated for high myopia were more likely to be overcorrected than low myopia patients.

\section{Regression}

Regression (refractive error shift towards myopia), with or without significant haze is not the same as undercorrection (the desired correction was never achieved). In a large PRK study of more than 3000 eyes, $7.41 \%$ of the low myopic patients needed a retreatment for under-correction and regression. ${ }^{365}$ The main cause of the regression is probably keratocyte-mediated regrowth of the photoablated stroma. ${ }^{359}$ Another study ${ }^{366}$ showed that postoperative epithelial hyperplasia could be responsible for regression after PRK.

In LASIK, a forward shift of the posterior corneal surface of $40.9 \pm 24.8$ micron has been noticed. ${ }^{367}$ Thinner corneas and corneas requiring greater ablation are more predisposed to the anterior shift. Another study showed a central corneal steepening after LASIK. ${ }^{368}$ In eyes with severe regression after LASIK, Lohmann and Guell, ${ }^{369}$ and Spadea and coauthors ${ }^{370}$ found a significant increase of the epithelium thickness. They suggest that postoperative epithelial hyperplasia may play a role in postoperative regression. 


\section{Postoperative multifocality of the cornea}

Postoperatively, videokeratography has been used to evaluate centration of the refractive surgery, ${ }^{371}$ fluctuating vision, ${ }^{372}$ multifocality, ${ }^{373}$ regression, ${ }^{374}$ and induced astigmatism. ${ }^{375}$ Irregularity and multifocality of the postoperative cornea and decentration of the ablated zone can reduce the optical quality of the cornea. ${ }^{376}$ One year postoperatively, Hersh and coauthors ${ }^{377}$ found regular corneal topography patterns in $59 \%$ and irregular patterns in $41 \%$ of patients. Irregular topographical patterns can be induced by the photoablation itself, as well as by the wound healing response. ${ }^{378}$ Decentration of the photoablation zone may lead to diminished visual function with glare, monocular diplopia or refractive astigmatism. ${ }^{379}$

Decentration has been defined as the distance of the apparent center of the ablation to the apparent center of the pupil as viewed with videokeratography. ${ }^{380}$ The unique normal to the cornea however is established by the fixation of the subject onto a fixation light in the laser and in the corneal topography instrument, not to the corneal vertex, center of curvature, apex, or visual axis. ${ }^{381}$

Table 2-13 Decentration rates after PRK and LASIK without the use of a tracking system

\begin{tabular}{|c|c|c|c|c|c|c|}
\hline \multirow{2}{*}{$\begin{array}{l}\text { Author } \\
\overline{\text { Cavanaugh }^{382}}\end{array}$} & Year & \multicolumn{2}{|c|}{$\begin{array}{r}\text { Treatment No } \\
\text { of eyes }\end{array}$} & \multirow{2}{*}{$\begin{array}{l}\text { Decentration } \mathrm{mm} \\
\text { mean } \pm \mathrm{SD} \text { (range } \mathrm{mm} \text { ) } \\
0.52 \pm \mathrm{NR}(0 \text { to } 1.64)\end{array}$} & \multicolumn{2}{|c|}{$\begin{array}{l}\text { Decentration mm } \\
>0.5(\%)>1.0(\%)\end{array}$} \\
\hline & 1993 & PRK & 110 & & 43 & 7 \\
\hline $\operatorname{Lin}^{383}$ & 1994 & PRK & 502 & $0.34 \pm 0.2(0$ to 1.50$)$ & NR & 1 \\
\hline Talley $^{384}$ & 1994 & PRK & 85 & $0.57 \pm 0.4(0.1$ to 2.6$)$ & 20 & NR \\
\hline Schwartz ${ }^{385}$ & 1995 & PRK & 185 & $0.46 \pm \mathrm{NR}$ ( 0 to 1.44$)$ & 36 & 3 \\
\hline Almendral $^{386}$ & 1996 & PRK & 17 & $0.17 \pm 0.1(0.03$ to 0.39$)$ & 0 & 0 \\
\hline Aktunç $^{387}$ & 1996 & PRK & 49 & $0.85 \pm \mathrm{NR}(0.5$ to 1.0$)$ & 49 & 8 \\
\hline Deitz $^{388}$ & 1996 & PRK & 70 & $0.62 \pm 0.3(0.07$ to 1.67$)$ & 41 & 9 \\
\hline Mulhern ${ }^{389}$ & 1997 & LASIK & 36 & $0.48 \pm N R(N R)$ & 28 & 6 \\
\hline $\mathrm{Lee}^{390}$ & 1999 & PRK & 43 & $0.35 \pm 0.2(\mathrm{NR})$ & 7 & 5 \\
\hline
\end{tabular}

NR, not recorded; PRK, photorefractive keratectomy; LASIK, laser in situ keratomileusis 


\section{Review of the literature}

Centering the ablation on the line of sight creates corneal asymmetry when measured with the videokeratoscope. The line of sight tends to appear displaced below the pupil center. ${ }^{395}$ The correct interpretation of decentration is further complicated by the accuracy with which the ablation is centered and by the shift in vertex location. ${ }^{391}$

Decentration is difficult or impossible to detect with traditional tools, ${ }^{371,392}$ but can be seen and can be measured over the entrance pupil with topographical analysis. The range of ablation zone decentration in PRK and in LASIK patients varies from 0.0 to $2.60 \mathrm{~mm}$ (Table 2-13). ${ }^{382,384}$

A decentered stromal ablation may occur if the patient's eye slowly begins to drift and loses fixation, or if the surgeon improperly positions the patient's head. Decentrations are usually associated with greater attempted corrections. ${ }^{393}$ Centration in PRK and LASIK procedures is a critical aspect of the surgical technique utilizing eye trackers. Optimum centration minimizes side effects such as glare and halo, and optimizes patients' visual potential, but centration may vary because the pupil does not dilate or constrict symmetrically. ${ }^{394}$

Klyce and coauthors, ${ }^{395}$ and Deitz and coauthors ${ }^{388}$ reported poor correlation between the amount of decentration and BSCVA. This is in contrast to Azar and coauthors, ${ }^{396}$ who found a lower visual acuity in patients with highly displaced ablation zones. Aktunç and coauthors ${ }^{387}$ found an increase in postoperative astigmatism in patients with a decentered ablation zone.

Lee and coauthors ${ }^{390}$ found a larger decentration in LASIK patients 0.47 $\pm 0.30 \mathrm{~mm}$ as compared to $0.35 \pm 0.22 \mathrm{~mm}$ in PRK, and less decentration in males, in the second operated eye and older patients. Tsai and coauthors ${ }^{397}$ used an eye tracker and also noticed significant differences between first $(0.39 \pm 0.26$ $\mathrm{mm})$ and second $(0.29 \pm 0.23 \mathrm{~mm})$ eye, and between low and high myopia. They found the use of an eye-tracker helpful to avoid large decentration.

\section{Optical aberrations}

Spherical aberration can be avoided by additional flattening of the peripheral ablation zone. ${ }^{398}$ During the first years of PRK, some patients reported optical aberrations, including ghost images and halos, ${ }^{399}$ and loss of low-contrast visual acuity. ${ }^{400}$ These complaints seem to be exacerbated at night and are most prevalent in young myopic people with large scotopic pupillary diameters. ${ }^{401}$ The symptoms most likely are caused by an optical zone that is smaller than or decentered to the entrance pupil ${ }^{402}$ under conditions of dimillumination. ${ }^{403}$ Significant night vision complications after refractive surgery 


\section{Chapter 2}

have been reported in $14 \%$ to $32 \%$ of patients. ${ }^{404,405}$ Measuring wavefront errors, subclinical decentration (less than $1.0 \mathrm{~mm}$ ) was found to be a major factor in increased coma-like and spherical-like aberration after corneal laser surgery. ${ }^{406}$

Chapter 7 describes the efficacy of enlargement of the PRK ablated $5.0 \mathrm{~mm}$ zone diameter to $6.0 \mathrm{~mm}$ in combination with treatment of the undercorrections.

\section{Flap related complications in LASIK}

Operative complications of the microkeratome occurs mostly during the 'learning curve' of the surgeon. ${ }^{407}$ Complications may include transection of the flap, ${ }^{408}$ a flap buttonhole, ${ }^{409}$ a thin flap ${ }^{410}$ interruption of the mechanism with an inadequate cut, and a free corneal cap. ${ }^{411}$ Some intraoperative microkeratome- or flap related complications may lead to abandonment of the laser treatment. ${ }^{410}$ Knorz and coauthors ${ }^{412}$ mentioned microkeratome related complications in 1.3 $\%$ of patients. Knorz also mentioned other intraoperative complications in 1.7\% of the patients such as epithelial defects, flap dislocations, ${ }^{4 / 3}$ and lateral canthotomy. Walker and coauthors ${ }^{414}$ found a lower microkeratome related complication rate with the Hansatome microkeratome (B\&L Surgical, Claremont, $\mathrm{CA}$ ) than with the Automated Corneal Shaper (Chiron Division, Claremont, CA).

Other intraoperative complications include unintended thinning of the remaining stromal bed, which may produce a corneal ectasia after several months or years following LASIK. ${ }^{415,416,417}$ Wang and coauthors ${ }^{418}$ correlated corneal bulge with residual stromal bed thickness, and found that the risk of ectasia may be increased if the residual corneal bed is thinner than $250 \mu \mathrm{m}$. The importance of preoperative corneal pachometry and corneal topography to avoid treatment of eyes with beginning keratoconus was proven by Schmitt and coauthors, ${ }^{419}$ and Speicher and coauthors. ${ }^{420}$ In most cases of ectasia, corneal transplantation was required for final visual rehabilitation.

Postoperative complications include: displaced flaps, ${ }^{421,422}$ folds or microwrinkles in the flap, ${ }^{423}$ diffuse lamellar keratitis (sands of Sahara syndrome), ${ }^{424}$ infectious keratitis, ${ }^{425}$ and epithelial ingrowth. ${ }^{426}$ 
Surgical techniques to correct complications following corneal refractive surgery

First, surgeons need to avoid factors that can lead to serious complications of laser refractive surgery by using caution when treating high refractive errors, particularly with retreatments, recognizing early keratoconus and avoiding laser treatment under a partial flap in LASIK ${ }^{427}$ Corneal topography should always be performed before refractive surgery to rule out early keratoconus. ${ }^{428,429}$

\section{Central islands}

Techniques to reduce the incidence of central islands are first a matter of prevention. Several modalities such as anti-island software, thicker flaps, or wiping the stromal base frequently may minimize the occurrence of central islands. ${ }^{430}$ The introduction of scanning spot lasers reduced the number of central islands. Central islands can be treated by transepithelial phototherapeutic keratectomy guided by epithelial fluorescence without modulating agents, and subsequently treated with PRK, which results in improved visual outcome. ${ }^{431}$

\section{Regression}

It is estimated that 5 to $10 \%$ of PRK patients will have a significant amount of residual myopia and will be candidates for retreatment. ${ }^{432}$ Indications are undercorrection and regression, with or without significant haze.

Refraction and corneal topography need to be stable for at least three months. Numerous authors have described their techniques and results of PRK retreatment. $^{433,434}$ The surgical techniques were similar to primary PRK treatments, except that the epithelial removal is done by the laser.

In general, the clinical results of retreatment of regression were satisfactory, ${ }^{435}$ but not as good as results from primary procedures. Gartry and coauthors $^{442}$ retreated $106 \mathrm{PRK}$ eyes with an initial mean refraction of $-6.73 \mathrm{D}$ $( \pm 2.87)$, and a mean refraction before retreatment of $-3.14 \mathrm{D}( \pm 2.21)$. Eighteen months after retreatment, the mean refraction was $-1.75 \mathrm{D}( \pm 2.01)$. The presence of significant anterior stromal haze after the first procedure was the most important predictor of a poor outcome after retreatment. There is a subgroup of patients who require multiple PRK retreatments for myopic regression. ${ }^{436}$ 


\section{Chapter 2}

The percentage of retreatments in LASIK patients is lower. PerezSantonja and coauthors ${ }^{437}$ showed an increase from $3.3 \%$ to $61.8 \%$ in uncorrected visual acuity (UCVA) of 20/40 after retreatment. Durrie and coauthors ${ }^{438}$ recorded uncorrected visual acuity of $20 / 40$ or better in $92 \%$ of retreated eyes. Zadok and coauthors ${ }^{439}$ noticed improvement of UCVA to $20 / 40$ in $96 \%$ of the retreated patients, whereas $9.4 \%$ lost one line. Febbraro and coauthors $^{440}$ achieved UCVA of $20 / 40$ in all patients after the enhancement procedure. Refraction remained stable during the first year of follow-up. Lyle ${ }^{441}$ also noted UCVA of $20 / 40$ in $98 \%$ of retreated patients. Perez-Santonja ${ }^{437}$ noticed that, just as in PRK, the predictability after retreatment was not as good as that obtained in eyes with only one LASIK procedure.

\section{Decentered ablation zones and irregular corneas}

Retreatment of a significantly decentered ablation zone is difficult. ${ }^{442}$ Alkara and coauthors ${ }^{443}$ developed a technique of re-operation for eccentric ablations after PRK, called diametral ablation. This technique uses a transepithelial PTK that leaves epithelium over the area of primary PRK. This residual epithelium acts as a shield for the previously treated stroma during the second PRK located opposite of the primary PRK, with reference to the pupil center. They reduced the eccentricity from $1.43 \pm 0.66$ to $0.36 \pm 0.15 \mathrm{~mm}$. LimBon-Siong and coauthors ${ }^{444}$ used the same technique in two cases.

Perhaps we can better rely on topographic-driven photorefractive keratectomy, as demonstrated by Alessio and coauthors. ${ }^{445}$ Their reports on 42 eyes with irregular astigmatism are promising: only one eye lost one line and the other eyes were within 1 diopter of attempted correction and all eyes had UCVA better than 20/40. This is in contrast to the report of Wiesinger-Jendritza and coauthors, ${ }^{2.38}$ using a topographically-driven laser in irregular astigmatic corneas of 23 eyes, resulting in less corneal irregularity in $81 \%$ of eyes. Four eyes had to be retreated for undercorrections, and three eyes for regression. The latest report from Knorz and coauthors ${ }^{446}$ sounds promising, with a topographically driven laser, they improved corneal regularity in $66 \%$ of postkeratoplasty eyes, in $83 \%$ of a group with decentered ablations, and in $91 \%$ of a group with central islands. Photo Ablated Lenticular Modulator (PALM), invented by Pallikaris, ${ }^{477}$ tries to minimize or abolish corneal irregularities using a multicomponent biocompatible material with the same ablation rate as the corneal stroma as a masking agent in PRK retreatments and PTK. This technique is undergoing clinical trials and appears promising. 
Flap related complications

Lifting and refloating with sterile deionized water can successfully treat flap wrinkles. ${ }^{448}$ Serious epithelial ingrowth under the flap can result in progressive keratolysis with irregular astigmatism and loss of vision. ${ }^{449}$ Large epithelial profile changes were noticed after LASIK. ${ }^{450}$ As far as we know now, corneal wound healing following LASIK is variable between eyes. ${ }^{451}$ An animal study proved continued wound healing at 9 months after LASIK. ${ }^{452}$ Very highultrasound corneal analyses identified irregularities in the epithelial-stromal interface, that accounted for image ghosting present despite apparently normal videotopgraphy. ${ }^{453}$

In recent large LASIK studies with over 1000 eyes, no cases of corneal flap loss are reported ${ }^{454.455}$ In the case of flap loss, epithelial tissue covers the bare stroma within a few days but irregularities of the epithelial layer can result in irregular astigmatism and loss of vision.

In chapter 8 we describe three patients with a flap loss and the contact lens fiting technique to rehabilitate visual performance.

In chapter 9 we describe a contact lens fitting procedure and results in a patient with keratectasia following LASIK.

\section{Contact lens fitting techniques to improve vision after refractive surgery complications}

Overcorrection can be treated with daily wear soft contact lenses as proven by Lim and coauthors, ${ }^{460}$ or with glasses.

Although many surgical techniques have been developed to treat complications induced by PRK and LASIK, the results of these surgical techniques appear disappointing. RGP lenses, which create a new refractive anterior surface of the eye, have been used and designed to treat these specific cases. The tear-film between the contact lens and the anterior corneal surface eliminates irregularities of the corneal surface.

Decentration or multifocality of the cornea following refractive surgical procedures has been corrected with rigid gas permeable contact lenses (Table 214). None of the authors used the same contact lens fitting technique. Schipper and coauthors ${ }^{48}$ used aspheric RGP lenses in eight eyes of PRK patients, using 


\section{Chapter 2}

fluorescein staining to evaluate contact lens movement and centration. The best fit was achieved by fitting the center steep, with alignment in the midperipheral part and clearance in the periphery. After photorefractive surgery, the average back optic zone radius (BOZR) was $0.065 \mathrm{~mm}$ flatter than before surgery. All patients could be corrected with contact lenses to at least the same visual acuity as before surgery.

Astin and coauthors ${ }^{456,457}$ published several papers about RGP contact lens fitting after PRK, all concerning the same patient population. They choosed the BOZR $0.25 \mathrm{~mm}$ steeper than the flattest post-PRK central keratometer reading and assessed lens fitting with the fluorescein pattern. The aspheric back surface was selected with the intention of peripheral bearing and an even distribution of lens pressure, smooth lens movement, and good tear exchange.

Table 2-14 Contact lens fitting following excimer laser refractive surgery

\begin{tabular}{|c|c|c|c|c|c|}
\hline $\begin{array}{l}\text { Author } \\
\text { Year }\end{array}$ & $\begin{array}{l}\text { Type of } \\
\text { surgery }\end{array}$ & $\begin{array}{l}\text { No } \\
\text { of eyes }\end{array}$ & $\begin{array}{l}\text { Type of } \\
\text { lenses use }\end{array}$ & $\begin{array}{l}\text { Determining } \\
\text { BOZR }\end{array}$ & $\begin{array}{l}\text { Total lens diameter } \\
\text { range in mm (mean) }\end{array}$ \\
\hline $\begin{array}{l}\text { Schipper }{ }^{458} \\
1995\end{array}$ & PRK & 13 & RGP & fluorescein & $8.6-10.8(9.51)$ \\
\hline Astin $^{459}$ & PRK & 5 & RGP & $0.25 \mathrm{~mm}$ steeper than flat $\mathrm{K}$ & $9.2-10.00(9.57)$ \\
\hline 1996 & & 5 & Soft & $0.3 \mathrm{~mm}$ flatter flat $\mathrm{K}$ & 14.0 \\
\hline $\operatorname{Lim}^{460}$ & PRK & 16 & RGP & mid-peripheral & $9.2-9.6 \quad(9.24)$ \\
\hline 1999 & & 7 & Soft & m.o.b. & $13.5-14.5(13.95)$ \\
\hline $\begin{array}{l}\operatorname{Lim}^{261} \\
2000\end{array}$ & PRK & 9 & RGP* ts & topography & 9.51 \\
\hline
\end{tabular}

m.o.b., Movement on blinking; *, Reversed geometry; BOZR, back optic zone radius; PRK, photorefractive keratectomy. 
Lim and coauthors (1999) ${ }^{460}$ described contact lens fitting after PRK in 16 patients with residual ametropia. They used the post-PRK central keratometry readings to determine the initial BOZR and, after insertion of the trial lens, the $B O Z R$ was adjusted in the direction of values closer to the preoperative central keratometry readings until mid-peripheral alignment or flatter was achieved. This fitting technique resulted in central fluorescein pooling of the tear film, corresponding to the laser ablation. They reported excellent visual acuity, at least equal to or better than pre-operative values. It was disappointing that only $25 \%$ of the patients successfully achieved all day RGP contact lens wear at their six months follow up.

In a recent paper, Lim and coauthors $(2000)^{261}$ used reverse geometry lenses (Plateau lens, Menicon Inc, Clovis, CA, USA) in nine patients. He used the transition zone on the topographic map for selection of the base curve (BC) (in case of reverse geometry is that the second curve), and needed the fluorescein pattern to refine the lens fitting. The difference between the $\mathrm{BC}$ and the BOZR varied from two to ten diopters; small differences between $\mathrm{BC}$ and $B O Z R$ reduced peripheral bearing, allowed more tear flow, increased lens movement, and helped a low riding lens to center better. Five patients achieved whole day contact lens wear with reasonable success.

Chou and coauthors ${ }^{461}$ fitted contact lenses on 24 eyes after keratomileusis, using the postoperative keratometry values for the selection of the BOZR of the first trial lens. The final lens was selected on the basis of fit, movement and tear exchange by the fluorescein pattern. They used a back optic zone diameter (BOZD) between 8.0 and $8.5 \mathrm{~mm}$ to reduce glare and minimize motion. The total contact lens diameter they used was larger than used by others (mean $10.00 \mathrm{~mm}$, range $9.4-11.0 \mathrm{~mm}$ ).

Szczotka and coauthors ${ }^{462}$ suggested the use of RGP contact lenses with a reversed geometry in LASIK patients, using the videokeratograph values for measuring the mid-peripheral curvature at the knee of the transition zone by moving the cursor to the different quadrants on the "bent" of the surgical optical zone for selection of the $\mathrm{BC}$, equal to or slightly flatter than the average across the transition zone. The central BOZR could be 2.00 or $3.00 \mathrm{D}$ flatter so that a 1 to $2 \mathrm{~mm}$ wide band of midperipheral bearing could be achieved with the $\mathrm{BC}$ over the 'bend'. All fitting techniques can be visualized by staining the tearfilm with fluorescein. No results of this proposed technique are presented. 


\section{Chapter 2}

Zadnik ${ }^{463}$ reviewed the prevailing clinical opinions on the use of contact lenses and contact lens fitting methods that are most effective after unsuccessful refractive surgery. No patient cases are presented.

We believe that rigid gas-permeable contact lenses offer advantages over soft lenses: they easily vault the central flattened cornea, and correct irregular astigmatism and most other optical aberrations. Rigid gas permeable contact lenses provide better and more stable visual acuity, and improve visual function. Since the peripheral cornea is essentially unchanged after LASIK and PRK, RGP lens fitting is simplified as compared with the post-RK ${ }^{464}$ patient in which corneal incisions induce direct shape changes in the periphery. ${ }^{465}$

Chapter 10 evaluates the efficacy of rigid gas permeable contact lens fitting techniques used in eyes with multifocal LASIK ablations to correct halo's and impaired night vision complaints. 


\subsection{REFERENCES}

${ }^{1}$ Edmund C. Posterior corneal curvature and its influence on corneal dioptric power. Acta Ophthalmol 1994;72:715-20

2 Knapp JH. Die krummung der hornhaut des menschliches auges. Heidelberg: SCB Mohr; 1860

${ }^{3}$ Berg F. Bemerkungen zur theorie der ophthalmometrischen messungen von

flachenkrummungen. Acta Ophthalmol 1992;7:225-243.

${ }^{4}$ Oshika T, Tomidokoro A, Tsuji H. Regular and irregular refractive powers of the front and back surface of the cornea. Exp Eye Res 1998;67:443-7.

${ }^{5}$ Maeda N, Klyce SD, Tano Y. Detection and classification of mild irregular astigmatism in patients with good visual acuity. Surv Ophthalmol 1998;43:53-8.

"Goss DA. Refractive error changes in mixed astigmatism. Ophthalmic Physiol Opt 1999;19:438-40

"Wong TY, Foster PJ, Hee J, Ng TP, Tielsch JM, Chew SJ, Johnson GJ, Seah SK. Prevalence and risk factors for refractive errors in adult Chinese in Singapore. Invest Ophthalmol Vis Sci 2000;41:2486-94

${ }^{8}$ Weakley DR. The association between anisometropia, amblyopia, and binocularity in the absence of strabismus. Trans Am Ophthalmol Soc 1999;97:987-1021.

"Achiron LR, Witkin N, Primo S, Broocker G. Contemporary management of aniseikonia. Surv Ophthalmol 1997;41;312-30

${ }^{10}$ Lubkin V, Kramer P, Meisinger D, Shippman S, Bennet G, Visintainer P. Aniseikonia in relation to strabismus, anisometropia and amblyopia. Binocul Vis Strabismus Q 1999;14:2037 .

"Lubkin V. Aniseikonia: findings of a 10-year study. Surv Ophthalmol 1997;41:321-30

12 Vaughan D, Asbury T. General Ophthalmology 7th edition; Lange Medical Publications, Los Altos, CA page 263

${ }^{1.3}$ Committee on Vision, National Research Council, National Academy of Sciences. Working group 39, Recommended standard procedure for the clinical measurement and specification of visual acuity. Advances in Ophthalmology 1980;41:103-48

${ }^{14}$ Holladay JT. Proper method for calculating average visual acuity. J Refractive Surg 1997;13:388-91.

${ }^{15}$ Holladay JT, Prager TC. Mean visual acuity. Am J Ophthalmol 1991;111:372-4.

${ }^{16}$ Sloan LL. Measurement of visual acuity. Arch Ophthalmol 1951;45:704.

${ }^{17}$ From the Editors. J Cataract Refract Surg 1998;24:285-7.

${ }^{1 *}$ Waring III GO. Standardized data collection and reporting for refractive surgery. J Refract Corneal Surg 1992;8(S):1-42.

${ }^{10}$ Stein H. President's message: Primium non nocere. Contact Lens Assoc Ophthalmol J 1984;10:122

${ }^{211}$ Kok JHC. Thesis, 1991. New developments in the field of contact lenses. De Vrieseborch, Haarlem, The Netherlands.

${ }^{21}$ Tuohy KM. Los Angeles, Calif, U.S.A. Pat. No. 2510438, application Feb. 28, 1948.

Patented June 6, 1950

22 Bier N. Contact lens routine and practice. 2nd edition 1957, Butterworths scientific publications, London.

${ }^{23}$ Rosenthal P, Cotter JM. Albert \& Jakobiec, Principals and Practice of Ophthalmology; 2nd Edition, WB Saunders Comp. Philadelphia Pennsylvania USA. 


\section{Chapter 2}

${ }^{21}$ Tomlinson A. Choice of materials-A material issue. Contact Lens Spectrum 1990;5:27

${ }^{25}$ Lembach RG. Rigid gas-permeable contact lenses. CLAO J 1990;16:129.

${ }_{26}^{26}$ McLaughlin R. Fluorosilicone-acrylate RGPs vs silicone-acrylate RGPs. Contact Lens Spectrum 1989;4:74

"7 Doane $M$, Gleason W. Tear film interaction with rigid gas-permeable contact lenses. presented at the First International Material Science Symposium, St. Louis, March 1988.

${ }^{2 *}$ Bruce AS, Brennan NA. Corneal pathophysiology with contact lens wear. Surv Ophthalmol 1990;35:25-58

${ }^{29}$ Michaels DD. Visual Optics and Refraction: A Clinical Approach, 3rd ed. St. Louis, CV Mosby, 1985, p 583

${ }^{30}$ Benjamin WP. Visual optics of contact lens wear. Bennett ES, Weissman BA (eds): Clinical Contact Lens Practice. Philadelphia, JB Lippincott, 1991.

${ }^{31}$ Smelser GK, Ozanics V. Importance of atmospheric oxygen for maintenance of the optical properties of the human cornea. Science 1952;115:140

${ }^{32}$ Holden BA, Sweeney DF, Sanderson G. The minimal precorneal oxygen tension to avoid corneal edema. Invest Ophthalmol Vis Sci 1984;25:476.

${ }^{3.3}$ Polse KA. Tear flow under hydrogel contact lenses. Invest Ophthalmol Vis Sci 1979;18:409.

${ }^{34}$ Bennett ES, Grohe RM. Rigid Gas-Permeable Contact Lenses. New York, Professional Press Books/Fairchild, 1986, p 434

${ }^{35}$ Efron N, Brennan NA. Simple measurement of oxygen transmissibility. Aust J Optom 1985;68:27-9

${ }^{36}$ Refojo MF. The siloxane bond in contact lens materials: Effect of methyl and phenyl content on oxygen permeability of silicone lenses. Int Contact Lens Clin 1984;11:83-5 ${ }^{37}$ Snyder CB. Silicone elastomer-Still a hope for the future. Contact Lens Spectrum 1989;4:35-7

${ }^{38}$ Brennan NA, Efron N, Holden BA. Oxygen permeability of hard gas permeable contact lens materials. Clin Exp Optom 1986;69:82-4

${ }^{39}$ Cohen SR, Polse KA, Brand RA. Stromal acidosis affects corneal hydrostatic control. Invest Ophthalmol Vis Sci 1992,33:134-8.

${ }^{40}$ Schoessler JP. Contact lens wear and the corneal endothelium. J Am Optom Assoc 1988;58:804-6.

"Bonanno JA, Polse KA. Corneal acidosis during contact lens wear: Effects of hypoxia and carbon dioxide. Invest Ophthalmol Vis Sci 1987;28:1514-6.

${ }^{12}$ Mac Rae SM, Matsuda M, Shellans S. The effects of hard and soft contact lenses on the corneal endothelium. Am J Ophthalmol 1986;102:50-5.

${ }^{43}$ Sweeney DF, Holden BA, Vannas A. The clinical significance of corneal endothelial polymegethism. Invest Ophthalmol Vis Sci Suppl 1985;26:53-5.

${ }^{44}$ Polse KA, Brand RA, Cohen SR. Hypoxic effects on corneal morphology and function Invest Ophthalmol Vis Sci 1990;31:1542-4

${ }^{45}$ Clements LD. Corneal acidosis, blebs, and endothelial polymegethism. Contact Lens Forum 1990;March:39-41

${ }^{15}$ Fatt I, Bieber MT. The steady-state distribution of oxygen and carbon dioxyde in the vivo cornea. 1. The open eye in air and the closed eye. Exp Eye Res 1968;7:103-12. 


\footnotetext{
${ }^{47}$ Fatt I, Weissman BA. Physiology of the eye: An introduction to the Vegetative Functions: Butterworth-Heinemann 1992

${ }^{78}$ Harvitt DM, Bonanno JA. Re-Evaluation of the oxygen diffusion model for predicting minimum contact lens $\mathrm{Dk} / \mathrm{t}$ values needed to avoid corneal anoxia. Optom Vis Sci 1999;76:712-9

${ }^{49}$ Harvitt DM, Bonanno JA. Direct noninvasive measurement of tear oxygen tension beneath gas-permeable contact lenses in rabbits. Invest Ophthalmol Vis Sci 1996;37:1026-36.

${ }^{50}$ Hill RM, Fatt I. Oxygen measurements under a contact lens. Am J Optom Arch Am Acad Optom 1964;41:382-7.

"Brennan NA, Efron N, Carney LG. Corneal oxygen availability during contact lens wear: a comparison of methodologies. Am J Optom Physiol Opt 1988;65:19-24.

${ }^{52}$ Sarver MD, Baggett DA, Harris MG, Louie K. Corneal edema with hydrogel lenses and eye closure: effect of oxygen transmissibility. Am J Optom Physiol Opt 1981;58:362-86.

${ }^{53}$ Sarver MD, Polse KA, Baggett DA. Intersubject differences in corneal edema response to hypoxia. Am J Optom Physiol Opt 1983;60:128-31.

s. Bonanno JA, Polse KA. Effect of rigid contact lens oxygen transmissibility on stromal pH in the living human eye. Ophthalmology 1987;94:1305-9.

${ }^{55}$ Harvitt DM, Bonanno JA. pH dependence of corneal oxygen consumption. Invest Ophthalmol Vis Sci 1998;39:2778-81.

${ }^{56}$ Morgan $\mathrm{PB}$, Efron $\mathrm{N}$. The oxygen performance of contemporary hydrogel contact lenses. Contact Lens Ant Eye 1998;21:3-6.

57 Alvord L, Court J, Davis T, Morgan CF, Schindhelm K, Vogt J, Winterton L. Oxygen permeability of a new type of high Dk soft contact lens material. Optom Vis Sci 1998;75:306.

${ }^{5 *}$ Wilson SE, Lin DTC, Klyce SD. Topographic changes in contact lens-induced corneal warpage. Ophthalmology 1990;97:734-44.

${ }^{59}$ Lebow KA, Grohe RM. Differentiating contact lens induced warpage from true keratoconus using corneal topography. CLAO J 1999;25:114-22

${ }^{\prime \prime \prime}$ Liu Z, Pflugfelder SC. The effects of long-term contact lens wear on corneal thickness, curvature, and surface regularity. Ophthalmology 2000;107:105-11.

${ }^{61}$ Corneal Topography; American Academy of Ophthalmology. Ophthalmology 1999; 106:1628-38.

${ }^{62}$ 1SO/DIS 8321-1. Ophthalmic optics - Specification for material, dimensional and optical properties of contact lenses - Part li Rigid corneal and scleral contact lenses.

${ }_{63}^{63}$ EN ISO 10338 1997. Optics and optical instruments - Contact lenses - Determination of curvature.

Gerger RE. Effect of contact lens motion on the oxygen tension distribution under the lens. $J$ Optom Physiol Opt 1976;51:441-6.

${ }^{65}$ Fatt I, Lin D. Oxygen tension under a soft or hard gas-permeable contact lens in the presence of tear pumping. J Optom Physiol Opt 1976;53:104-6.

${ }^{66} \mathrm{O}^{\prime} \mathrm{Car}$ ll $\mathrm{D}$. You cannot get off the new technology cycle - but you can learn to ride it. Global Contact 2000;24:31-33

${ }^{67}$ Osborn C. Optimizing RGP comfort through design changes. Presented at the European Research Symposium, Barcelona, October 1987.

${ }^{a k}$ Korb DR, Korb JE. A new concept in contact lens design-Parts I and II. J Am Optom Assoc 1970;41:1023-30.
} 


\section{Chapter 2}

(1) Philips AJ, Stone J. Contact Lenses. 1989. 3rd. Ed. Butterworths, London.

"Lowther GE. Contact Lenses, Procedures and Techniques. 1987, Butterworths, London

"Stein HA, Slatt BJ. Fitting guide for hard and soft contact lenses. 1977, The C.V. Mosby Company, Saint Louis

"2 Klyce SD, Martinez CE. Albert \& Jakobiec, Corneal Topography. Chapter 61 Principals and Practice of Ophthalmology, 2nd Edition, WB Saunders Comp. Philadelphia Pennsylvania USA

${ }^{7}$ Rabinowitz YS, Wilson SE, Klyce SD. Color Atlas of Corneal Topography, New York, Igaku-Shoin Medical Publishers, 1993

"Placido A. Neue Instumente Centralbl Prakt Augenheilkd 1882;6:30-1.

${ }^{3}$ Helmholtz HV. Handbuch der physiologischen Optik. Hamburg Germany, Leopold Voss, 1909

"Douthwaite WA, Evardson WT. Corneal topography by keratometry. Br J Ophthalmol $2000 ; 84: 842-7$

${ }^{7 n}$ Doss JD, Hutson RL, Rowsey JJ, Brown R. Method for calculation of corneal protile and power distribution. Arch Ophthalmol 1981;99:1261-5.

${ }^{7}$ Klyce SD Computer-assisted corneal topography: High resolution graphical presentation and analysis of keratoscopy. Invest Ophthalmol Vis Sci 1984;25:1426-35.

${ }^{79}$ Maguire LJ, Singer DE, Klyce SD. Graphic presentation of computer analyzed keratoscope photographs. Arch Ophthalmol 1987;105:223-30.

"Dingeldein SA, Klyce SD, Wilson SE. Quantitative descriptors of corneal shape derived from computer-assisted analysis of photokeratographs. Refract Corneal Surg 1989;5:372-8

${ }^{* 1}$ Hannush SB, Crawford SL, Waring GO III. Accuracy and precision of keratometry, photokeratoscopy, and corneal modeling on calibrated steel balls. Arch Ophthalmol 1989;107: 1235-9

82 Schultze RL. Accuracy of corneal elevation with four corneal topography systems. J Refractive Surg 1998;14:100-104.

${ }^{83}$ Liu Z, Pflugfelder SC. Corneal surface regularity and the effect of artificial tears in aqueous tear deficiency. Ophthalmol 1999;106;939-943.

${ }^{8.4}$ Ousley PJ, Terry MA. Hydration effects on corneal topography. Arch Ophthalmol $1996 ; 114: 181-5$

${ }^{8.5}$ Jongsma FHM. Shape measurement of the anterior eye surface. Thesis 1998, Eye Research Institute Maastricht.

${ }^{86}$ Hugger $\mathrm{P}$, Kohnen T, LaRosa FA. Comparison of changes in manifest refraction and corneal power after photorefractive keratectomy. Am J Ophthalmol 2000;129:68-75.

${ }^{87}$ Hannush SB, Crawford SL, Waring GO III. Reproducibility of normal corneal power measurements with a keratometer, photokeratoscope, and video imaging system. Arch Ophthalmol 1990;108:539-44

${ }^{88}$ Belin MW, Ratliff CD. Evaluating acquisition and smoothing functions of currently available videokeratoscopes. J Cataract Refract Surg 1996;22:421-26.

${ }^{89}$ Koch DD, Wakil JS, Samuelson SW, Haft EA. Comparison of the accuracy and reproduciblility of the keratometer and the EyeSys Corneal Analysis System Model 1. J Cataract Refract Surg 1992;18:342-7.

${ }^{91}$ Bafna S, Kohnen T, Koch DD. Axial, instaneous, and refractive formulas in computerized videokeratography of normal corneas. J Cataract Refract Surg 1998;24: 1 184-90. 


\section{Review of the literature}

"Klein SA, Mandell RB. Shape and refractive powers in corneal topography. Ophthalmol Vis Sci 1995;36:2096-2109

"2: Roberts C C Corneal topography: A review of terms and concepts. J Cataract Refract Surg $1996 ; 22: 624-29$

"Roberts $C$. Characterization of the inherent error in a spherically-biased corneal topography system in mapping a radially aspheric surface. J Refract Corneal Surg 1994:10; 103-6.

"Gobbi PG, Carones F, Brancato R. Keratometric index, videokeratography, and refractive surgery. J Cataract Refract Surg 1998;24:202-211

"Roberts C. Analysis of the inherent error of the TMS-I Topographic Modeling System in mapping a radially aspheric surface. Cornea 1995;14:258-65.

${ }^{r 4}$ Roberts $C$. The accuracy of power maps to display curvature data in corneal topography systems. Invest Ophthalmol Vis Sci 1994;35:3525-32

"Klyce SD Computer-assisted corneal topography Invest Ophthalmol Vis Sci 1984,25: 1427-32

Smith TW Corneal topography. Doc Ophthaimol 1997,43 249-76

"Wilson SE, Klyce SD, Husseini ZM. Standardized color-coded maps for corneal topography. Ophthalmology 1993;100:1723-7

(ru. Cuaycong M, Gay $C$, Emery J. Comparison of the accuracy of computerized

videokeratography and keratometry for use in intraocular lens calculations. J Cataract Refract Surg 1993;(Suppl)178.

Im Husain SE, Kohnen T, Maturi R. Computerized videokeratography and keratometry in determining intraocular lens calculations. J Cataract Refract Surg 1996;22:362-6.

1w. Wilson SE, Klyce SD Quantitative descriptors of corneal topography: A clinical study Arch Ophthalmol 1991;109:349-53

${ }^{117}$ Shiotani $Y$, Maeda $N$, Inoue T, Watanabe H, Inoue $Y$, Shimomura $Y$, Tano $Y$, Comparison of topographic indices that correlate with visual acuity in videokeratography. Ophthalmology $2000 ; 107: 55-64$

1"it Seiler T, Reckmann W, Maloney RK. Effective spherical aberration of the cornea as a quantitative descriplor in corneal topography. J Cataract Refract Surg 1993;19;155-65.

iti Chastang PJ, Borderie VM, Carvajal-Gonzalez S, Rostène W, Laroche L. Prediction of spectacle-corrected visual acuity using videokeratography. J Refract Surg 1990;15:572-9 1"r. Dingeldein SA, Klyce SD. The topography of normal corneas. Arch Ophthatmol 107:512, 1989

Bogan SJ, Waring GO, Ibrahim O. Classification of normal corneal topography based on computer-assisted videokeratography. Arch Ophthalmol 1990;108:945-9

lix Kanpolat A, Simsek T, Alp NM. The evaluation of normal comeal topography in emmetropic eyes with computer-assisted videokeratography. CLAO J 1997;23: 168-71

$16 "$ Budak K. Hamed AM, Friedman NJ, Koch DD. Corneal topography classification in myopic eyes based on axial, instantaneous, refractive, and profile different maps. J Cataract Refract Surg 1999;25: 1069-79

1'" Alvi NP, McMahon TT, Devulapally J Characteristics of normal corneal topography using EyeSys corneal analysis system. J Cataract Refract Surg 1997;23:849-55 


\section{Chapter 2}

${ }^{11}$ Rasheed K, Rabinowitz YS, Remba D, Remba MJ. Interobserver and intraobserver reliability of a classification scheme for comeal topographic patterns. $\mathrm{Br} \mathrm{J}$ Ophthalmol 1998;82:1401-6.

112 Douthwaite WA, Hough T, Edwards K, Notay H. The EyeSys videokeratoscopic assessment of apical radius and $\mathrm{p}$-value in the normal human cornea. Ophthal Physiol Opt 1999;19:467-74

${ }^{113}$ Lieberman DM, Grierson JW. The lids influence on corneal shape. Cornea 2000;19:336-42.

${ }^{114}$ Keller PR, Reid PG, Saarloos PP. Corneal topography bow-tie pattern: artifact of videokeratoscopy. J Cataract Refract Surg 1997;23:1339-44

${ }^{115}$ Budak K, Khater T, Friedman N, Holladay JT, Koch DD. Evaluation of relationships among refractive and topographic parameters. J Cataract Refract Surg 1999;25:814-20.

${ }^{116}$ Wilson SE, Friedman RS, Klyce SD. Contact lens manipulation of corneal topography after penetrating keratoplasty: A preliminary study. CLAO J 18:177, 1992.

117 Gomes JA, Cohen EJ, Rapuano CJ. Topographic stability and safety of contact lens use after penetrating keratoplasty. CLAO J 1996; 22:64.

${ }^{118}$ Sperber LT, Cohen EJ, Lopatynsky MO. Corneal topography in contact lens wearers following penetrating keratoplasty. CLAO J 21:183, 1995.

${ }^{119}$ Klyce SD, Estopinal HA, Gersten M. Fluorescein exam simulation for contact lens fitting. Invest Ophthalmol Vis Sci 1992;31:S697.

${ }_{120}$ Szczotka LB. Clinical evaluation of a topographically based contact lens fitting software. Optom Vis Sci 1997; 74: 14-9.

${ }_{1=1}$ Srivannaboon S, McDonald MB, Doubrava M, Klyce SD. A prospective clinical trial comparing a topographically guided artificial intelligence software system versus clinical expertise for fitting normal and pathological corneas with contact lenses. Invest Ophthalmol Vis Sci 1997;38:S1089.

${ }^{122}$ Rabinovitz YS, Garbus JJ, Garbus C. Contact lens selection for keratoconus using a coputer assisted videophotokeratoscope. CLAO J 1993;17:88-93.

${ }^{123}$ Szczotka LB, Lass JH, Capretta DM. Clinical evaluation of a computerized topography software method for fitting rigid gas permeable contact lenses. CLAO J 1994;20:231-6.

12.1 Donshik PC, Reisner DS, Luistro AE. The use of computerized videokeratography as an aid in fitting rigid gas permeable contact lenses. Trans Am Ophthalmol Soc 1996,94:135-45 ${ }_{12.5}$ Douthwaite W, Pardhan S. Comparising of a videokeratoscope and an autokeratometer as predictors of the optimum back surface curves of rigid corneal contact lenses. Opthal Physiol Opt 1997,17:409-13

${ }_{12 n}$ Bufidis T, Konstas AGP, Mamtziou E. The role of computerized corneal topography in rigid gas permeable contact lens fitting. CLAO J 1998;24:206-9.

${ }_{127}^{12}$ Liu E, Slomovic AR. Indications for penetrating keratoplasty in Canada, 1986-1995 Cornea 1997;16:414-9.

${ }_{128}$ Patel NP, Kim T, Rapuano CJ, Cohen EJ, Laibson PR. Indications for and outcomes of repeat penetrating keratoplasty. Ophthalmology 2000;107:719-24.

${ }_{129}$ Maeno A, Naor J, Lee HM, Hunter WS, Rootman DS. Three decades of corneal transplantation: indications and patient characteristics. Cornea 2000;19:7-11.

${ }^{130}$ Lois N, Kowal VO, Cohen EJ, Rapuano CJ, Gault JA, Raber IM, Laibson PR. Indications for penetrating keratoplasty and associated procedures, 1989-1995. Cornea 1997,16:623-9. 
${ }^{131}$ Bouruchoff SA, Frangie JP. Penetrating keratoplasty in: Albert \& Jakobiec, Principals and Practice of Ophthalmology; 2nd Edition, WB Saunders Comp. Philadelphia Pennsylvania USA.

${ }^{13}$ Olson RJ, Pingree M, Ridges R, Lundergan ML, Alldredge CJr, Clinch TE. Penetrating keratoplasty for keratoconus: a long term review of results and complications. J Cataract Refract Surg 2000;26:987-91

${ }^{1.33}$ Meyer HJ Zur prognose der Keratoplastik bei hereditary Stromadystrophien. Klin Monatsbl Augenheilkd 1996,208:440-9

${ }^{13 .}$ Groh MJ, Gusek-Schneider GC, Seitz B, Schonherr U, Naumann GO Ergebnisse nach perforierender Keratoplastik bei kongenitaler hereditarer Hornhaut-Endotheldystrophie (CHED). Bericht uber 13 Augen. Klin Monatsbl Augenheild 1998;213:201-6.

${ }^{137}$ Rasheed K, Rabinowitz YS. Surgical treatment of advanced pellucid marginal degeneration. Ophthalmology 2000;107:1836-40.

${ }^{13.1}$ Cursiefen C, Kuchle M, Naumann GO Changing indications for penetrating keratoplasty: histopathology of 1,250 corneal buttons. Cornea 1998,17:468-70.

${ }_{13}$ Naumann GO, Schlotzer-Schrehardt U. Keratopathy in pseudoexfoliation syndrome as a cause of corneal endothelial decompensation: a clinicopathologic study. Ophthalmology 2000; 107:1111-24

${ }^{136}$ Azuara-Blanco A, Pillai CT, Dua HS. Amniotic membrane transplantation for ocular surface reconstruction. Br J Ophthalmol 1999;83:399-402

13" Soong HK, Farjo AA, Katz. D, Meyer RF, Sugar A. Lamellar comeal patch grafts in the management of corneal melting. Cornea 2000;19:126-34.

1.* Brady SE, Rapuano CJ, Arentsen JJ. Clinical indications for and procedures associated with penetrating keratoplsty, 1983-1988. Am J Ophthalmol 1989;108:118-22.

1.11 Meier U, Anastasi C, Failla F, Simona F. Die Moglichkeiten der therapeutischen Photokeratektomie mil dem Excimerlaser bei der Behandlung der Schnijder kristalinen Hornhautdystrophie. Klin Monatsbl Augenheilkd 1998;212:405-6.

1.12 Rycroft BW: Corneal grafts. London, Butterworths, 1955

${ }^{1.11}$ Merchant AM, Foster CS. Lamellar keratoplasty: Albert \& Jakobiec, Principals and Practice of Ophthalmology; 2nd Edition, WB Saunders Comp. Philadelphia Pennsylvania USA.

${ }^{1+1}$ Von Hippel A. Eine neue methode der Hornhauttransplantation. Arch Ophthalmol Leipzich 1888;34:108.

${ }^{1: T}$ Melles GRJ, Remeijer L, Geerards AJM, Beekhuis WH. The future of lamellar keratoplasty. Current Opinion in Ophthalmol 1999;10:253-9

${ }^{1 \text { thi }}$ Soong HK, Katz. DG, Farjo AA, Sugar A, Meyer RF Central lamellar keratoplasty for optical indications. Comea 1999;18:249-56.

1: Polack FM. Lamellar keratoplasty. Malbran's "peeling off" technique. Arch Ophthalmol 1971:83:293-5

1.48 Morrison JC, Swan KC. Full-thickness lamellar keratoplasty. Ophthalmology 1982;89:7159.

1.11 Archila EA Deep lamellar keratoplasty dissection of host tissue with intrastromal air injection. Cornea 1984-1985;3:217-8

${ }^{15 i}$ Melles GRJ, Eggink FAGJ, Lander F, Pels E, Rietveld FJR, Beekhuis WH, Binder PS. A surgical technique for posterior lamellar keratoplasty. Cornea 1998;17:618-26. 


\section{Chapter 2}

\footnotetext{
${ }^{151}$ Melles GRJ, Rietveld FJR, Beekhuis WH, Binder PS. A technique to visualize corneal incision and lamellar dissection depth during surgery. Cornea 1999;18:80-6.

152 Price FW. Air lamellar keratoplasty. Refractive Corneal Surg 1989;5:240-3

${ }^{153}$ Haimovici R, Culbertson WW. Optical lamellar keratoplasty using the Barraquer microkeratome. Refract Corneal Surg 1991;7:42-45.

${ }^{15.1}$ Hanna KD, David T, Besson J, Pouliquen X. Lamellar keratoplasty with the Barraquer microkeratome. Refractive Corneal Surg 1991;7:177-81.

${ }^{15.5}$ Benson WH, Goosey CB, Prager TC, Goosey JD Visual improvement as a function of time after lamellar keratoplasty for keratoconus. Am J Ophthalmol 1993;116:207-11.

${ }^{156}$ Sugita J, Kondo J. Deep lamellar keratoplasty with complete removal of pathological stroma for vision improvement. Br J Ophthalmol 1997;81:178-9

${ }^{157}$ Krumeich JH, Daniel J. Lebend-epikeratophakie und Tief Lamelläre Keratoplastik zur Stadiengerechten chirurgischen Behandlung des Keratoconus (KK) I-III. Klin Monatsb I Augenheilkd 1997;21 1:94-100.

1.8 Tsubotha K, Kaido M, Monden Y, Satake Y, Bissen-Miyajima H, Shimazaki J. A new surgical technigue for deep lamellar keratoplasty with single running suture adjustment. Am J Ophthamol 1998;126:1-8

${ }^{15 \%}$ Krumeich JH, Daniel J, Winter M. Tiefe lamelläre Keratoplastik mit dem geführten Trepan System zur Übertragung van Spenderscheiben in ganzer Dicke. Ophthalmologe 1998;95:74854.

1iin Kaz Soong H, Katz DG, Farjo AA, Sugar A, Meyer RF. Central lamellar keratoplasty for optical indications. Cornea 1999;18:249-56

${ }^{161}$ Panda A, Singh Bageshwar LM, Ray M, Singh JP, Kumar A. Deep lamellar keratoplasty versus penetrating keratoplasty for corneal lesions. Cornea 1999;18:172-5

162 Amayem AF, Anwar M. Fluid lamellar keratoplasty in keratoconus. Ophthalmology $2000 ; 107: 76-80$

${ }^{163}$ Eggink FAGJ, Melles GRJ, Lander F, Geerarts AJM, Remeijer L, Beekhuis WH Preliminary results of the Rotterdam technique for deep, anterior lamellar keratoplasty. Investigative Ophthalmol Vis Science 1999;40: \$632(3323)

${ }^{164}$ Nieuwendaal C, Lander F, Melles GRJ. Clinical results of deep, anterior lamellar keratoplasty following manual dissection through a scleral tunnel incision. Submitted 16 Vajpayee RB, Thomas S, Sharma N, Dada T, Tabin GC Large diameter lamellar keratoplasty in severe ocular alkali burns: A technique of stem cell transplantation. Ophthalmology 2000;107:1765-8.

${ }^{166}$ Serdarevic O. Reflections on refractive surgery. Eurotimes 2001:6:5

16" Morris RJ, Bates AK. Changing indications for keratoplasty. Eye 1989:3:455-9

${ }^{168}$ Geerards AJM, Hassmann E, Beekhuis WH, Remeyer L, van Rij G, Rijneveld WJ. Triple procedure; analysis of outcome, refraction; and intraocular lens power calculation. Br I Ophthalmol 1997;81:774-7.

${ }^{169}$ Brierly SC, Izquierdo L, Mannis MJ. Penetrating keratoplasty for keratoconus. Cornea 2000;19:329-32

${ }^{1 *}$ Smiddy WE, Hamburg TR, Kracher GP, Stark WJ. Visual correction following penetrating keratoplasty. Ophthalmic Surg 1992;23:90-3.

${ }^{11}$ Mannis MJ. Indications for contact lens fitting after keratoplasty. CLAO J 1986;12:225-8
} 


\footnotetext{
" Serdarevic ON, Renard GJ, Pouliquen Y'. Randomized clinical trial of penetrating keratoplasty. Before and after suture removal comparison of intraoperative and postoperative suture adjustment. Ophthalmology 1995;102: 1497-503.

${ }^{1,3}$ Koralewska-Makar A, Floren I, Stenevi U. The results of penetrating keratoplasty for keratoconus. Acta Ophthalmol Scandinavica 1996;74: 187-90

i"4 Silbiger JS, Cohen EJ, Laibson PR. The rate of visual recovery after penetrating keratoplasty for keratoconus. CLAO J 1996;22:266-9.

"Yorston D, Wood A, Foster A. Penetrating keratoplasty in Africa: graft survival and visual outcome. Br J Ophthalmol 1996,80:890-4

"'Pineros O, Cohen EJ, Rapuano Laibson PR. Long-term results after penetrating keratoplasty for Fuchs endothelial dystrophy. Arch Ophthalmol 1996,114:15-8.

"- Filatov V, Alexandrakis G, Talamo JH, Steinert RF. Comparison of suture-in and sutureout postkeratoplasty astigmatism with single running suture or combined running and interrupted sutures. Am J Ophthalmol 1997;123:715-6.

${ }^{178}$ Buzard KA, Fundingsland BR. Corneal transplant for keratoconus results in early and late disease. J Cataract Refract Surg 1997;23:398-406.

" Karabatsas CH, Cook SD, Figueiredo FC, Diamond JP, Easty DL. Combined interrupted and continuous versus single continuous adjustable suturing in penetrating keratoplasty: a prospective, randomized study of induced astigmatism during the first postoperative year. Ophthalmology 1998;105:1991-8.

${ }^{18 n}$ Ruhswurm I, Scholz U, Pfleger T, Zehetmayer M, Hanselmayer G, Skorpik G. Three-year clinical outcome after penetrating keratoplasty for keratoconus with the guided trephine system. Am J Ophthalmol 1999;127:666-73

${ }^{181}$ Olson RJ, Pingree M, Rides R, Lundergan ML, Alldredge C. Clinch TE Penetrating keratoplasty: A long-term review of results and complications. J cataract Refract Surg 2000;26:987-91

ik: Brahma A, Ennis F, Harper R, Ridgway A, Tullo A. Visual function after penetrating keratoplasty for keratoconus a prospective longitudinal evaluation $\mathrm{Br} J$ Ophthalmol $2000,84: 60-6$

${ }^{183}$ Lim L, Pesudovs K, Coster DJ. Penetrating keratoplasty for keratoconus: Visual outcome and success. Am J Ophthalmol 2000;107:1125-31.

is. Brierly SC, Izquierdo L, Mannis MJ. Penetrating keratoplasty for keratoconus. Cornea 2000;19:329-32.

Is Mannis MJ, Zadnik K. Refracting the corneal graft. Surv Ophthalmol 1990;34:436-40.

Ixt Van Rij G, Warring GO III. Configurations of corneal trephine openings using five different trepines in human donor eyes. Arch Ophthalmol 1988;106: 1228-33.

is Vöker Dieben HJ, van Rij G. Management of post-keratoplasty astigmatism: Laser and Conventional Refractive Surgery. Edited by Claoué C. London:BJM;1996 346-76

${ }^{1 * k}$ Beekhuis WH, van Rij G. Eggink FAGJ, V'reugdenhil W, Schoevaart CE. Contact lenses following keratoplasty CLAO J 1901;17:1:27-29

Is" Binder PS. The effect of suture removal on post-keratoplasty astigmatism. Am J Ophthalmol 1988:105:637-45.

${ }^{131}$ Hoppenreijs VPT, van Rij G, Beekhuis WH, Rijneveld WJ. Rinkel van Driel E. Causes of high astigmatism after penetrating keratoplasty. Doc Oplithalmol 1993:85:21-34
} 


\section{Chapter 2}

${ }^{191}$ Hjortdal JØ, Ehlers N, Erdmann L. Topography of corneal grafts before and after penetrating keratoplasty. Acta Ophthalmol Scand 1997;75:645-8

192 Williams KA, Ash JK, Pararajasegaram P, Harris S, Coster DJ. Long-term outcome after corneal transplantation. Visual results and patient perception of success. Ophthalmology 1991;98:651-7

${ }^{193}$ Maguire LJ. Bourne WM. Corneal topography of transverse keratotomies for astigmatism after penetrating keratoplasty. Am J Ophthalmol 1989;107:323-30.

${ }^{194}$ Karabatsas CH, Cook SD, Powel K, Sparrow JM. Comparison of keratometry and videokeratography after penetrating keratoplasty. J Refractive Surg 1998;14:420-426. ${ }^{195}$ Karabatsas $\mathrm{CH}$, Cook SD, Sparrow JM. Proposed classification for topographic patterns seen after penetrating keratoplasty. Br J Ophthalmol 1999;83:403-9

${ }^{196}$ Ibrahim $\mathrm{O}$, Bogan S, Waring GO Patterns of corneal topography after penetrating keratoplasty. Eur J Ophthalmol 1996;6:1-5.

${ }^{19}$ Shimazaki J, Tsubota K. Analysis of videokeratography after penetrating keratoplasty. Ophthalmology 1997;104:2077-2084.

${ }^{10 x}$ Khong AM, Mannis MJ, Plotnik RD, Johnson CA. Computerized topographic analysis of the healing graft after penetrating keratoplasty for keratoconus. Am J Ophthalmol 1993;115:209-15.

${ }^{109}$ McNeill JL, Aaen VJ. Long-term results of single continuous suture adjustment to reduce penetrating keratoplasty astigmatism. Cornea 1999;18:19-24

${ }^{2}$ "'t Strelow S, Cohen EJ, Leavit KG, Laibson PR. Corneal topography for selective suture removal after penetrating keratoplasty. Am J Ophthalmol 1991,112:657-65.

2u Touzeau O, Borderie VM, Allouch C, Scheer S, Laroche L. Effects of penetrating keratoplasty suture removal on corneal topography and refraction. Cornea 1999,18:638-44 202 Goren MB, Reza Dana M, Rapuano CJ, Gomes JA, Cohen EJ, Laibson PR Corneal topography after selective suture removal for astigmatism following keratoplasty. Ophthalmic Surg and Lasers 1997,28:208-14

${ }^{2013}$ Solomon A, Siganos CS, Frucht-Pery J. Relaxing incisions guided by videokeratography for astigmatism after keratoplasty for keratoconus. J Refract Surg 1999; 15:343-8.

${ }^{204}$ Artaria LG. Computerisierte Hornhauttopographie in der Behandlung des hochgradigen Astigmatismus nach perforierender Keratoplastik. Klin Monatsbl Augenheilkd 1995;206:312-

215 Dana MR, Goren MB, Gomes JAP, Laibson PR, Raputano CJ, Cohen EJ. Suture erosion after penetrating keratoplasty. Cornea 1995;14:243-8

2ks Beekhuis WH.Current clinician's opinions on risk factors in corneal grafting. Results of a survey among surgeons in the Eurotransplant area. Cornea 1995;14:39-42.

"Van Rensburg PD, Raber IM, Laibson PR, Eagle RC Jr. Management of primary corneal graft failure Cornea 1998;17:208-11

בıK Price FW, Whitson WE, Collins KS, Marks RG. Five-year corneal graft survival. Arch Ophthalmol 1993; 1 1 1:799-805.

:(") Chan CM, Wong TY, Yeong SM, Lim TH, Tan DT. Penetrating keratoplasty in the Singapore National Eye Center and donor cornea accuisition in the Singapore eye bank. Ann Acad Med Singapore 1997,26:395-400

I" Inoue $\mathrm{K}$, Amano S, Oshika T, Sawa M, Tsuru T. A 10 ycar review of penetrating keratoplasty. Jpn J Ophthalmol 2000;44: 139-45. 


\section{Review of the literature}

211 Nishimura JK, Hodge DO, Bourne WM. Initial endothelial cell density and chronic endothelial cell loss rate in corneal transplants with late endothelial failure. Ophthalmology 1999;106: 1962-5

212 Akova YA, Onat M, Koc F, Nurozier A, Duman S. Microbial keratitis following penetrating keratoplasty. Ophthalmic Surg Lasers 1999;30:449-55.

${ }_{21.3}$ Vabres B, Duffas M, Stork L, Percherau A. Facteurs non immunologiques d'echc des keratoplasties perforantes. Etude prospective de 119 greffes de cornee au CHU de Nantes sur l'annee 1995. J Fr Ophtalmol 1999;22:33-8.

${ }^{214}$ Cameron JA, Antonios SR, Cotter JB, Habash NR. Endophthalmitis from contaminated donor corneas following penetrating keratoplasty. Arch Ophthalmol 1991;109:54-9.

${ }^{21.5}$ Varley GA, Meisler DM. Complications of penetrating keratoplasty graft infections. Refract Corneal Surg 1991;7:62-6

216 Fong LP, Ormerod LD, Kenyon KR, Foster CS. Microbial keratitis complicating penetrating keratoplasty. Ophthalmology 1988;95:1269-75.

$=1$ Troutman RC, Swinger CA, Belmont S. Selective positioning of the donor cornea in penetrating keratoplasty for keratoconus: postoperative astigmatism. Cornea 1984;3:135-9 ${ }^{2 ! *}$ Van Meter WS, Gussler JR, Soloman KD, Wood TO. Post-keratoplasty astigmatism control: Single continuous suture adjustment versus selective interrupted suture removal. Ophthalmology 1991;98:177-83.

${ }^{2112}$ Lin DT, Wilson SE, Reidy JJ. An adjustable single running suture technique to reduce postkeratoplasty astigmatism: A preliminary report. Ophthalmology 1990;97:934-8.

${ }_{220}$ Burk LL, Waring GO III, Haris DJ Jr. Simultaneous and sequential selective suture removal to reduce astigmatism after penetrating keratoplasty. Refract Corneal Surg 1990;6: 176-81

$: 21$ Burk LL, Waring GO III, Radjee B, Stulting RD. The effect of selective suture removal on astigmatism following penetrating keratoplasty. Ophthalmic Surg 1988;19:849-54.

I2. Hardten DR, Lindstrom RL. Surgical correction of refractive errors after penetrating keratoplasty. Int Ophthalmol Clin 1997:37: $1-35$

23 Lustbader JM, Lemp MA. The effect of relaxing incisions with multiple compression sutures on post-keratoplasty astigmatism. Ophthalmic Surg 1990;21:410-9.

$\because$ Limberg MB, Dingeldein SA, Green MT. Corneal compression sutures for the reduction of astigmatism after penetrating keratoplasty. Am J Ophthalmol 1989;108:36-42.

Amm M, Duncker GI, Schroder E. Excimer laser correction of high astigmatism after keratoplasty. J Cataract Refract Surg 1996;22:313-7.

32: Lazzaro DR. Haight DH, Belmont SC, Gibralter RP, Aslanides IM, Odrich MG. Excimer laser keratectomy for astigmatism occurring after penetrating keratoplasty. Ophthalmology $1996,103458-64$.

$\because 2$ Tuunanen TH, Ruusuvaara PJ, Uusitalo RJ, Tervo TM Photoastigmatic keratectomy for correction of astignatism in corneal grafts. Cornea 1997;16:48-53.

$2{ }^{\mathrm{K}}$ Yoshida K, Tazawa Y, Demong TT. Refractive results of post penetrating keratoplasty photorefractive keratectomy. Ophthalmic Surg Lasers 1999;30:354-9.

:29' Bansal AK. Photoastigmatic refractive keratectomy for correction of astigmatism after keratoplasty. J Refract Surg 1999,15: S243-5

2w Koffler BH, Smith VM Comeal topography, arcuate keratotomy, and compression sutures for astigmatism after penetrating keratoplasty. J Refract Surg 1996; 12:S306-9. 
${ }^{231}$ Chastang $\mathrm{P}$, Borderie V, Carvajal S, Laroche L. Con'ection chirurgicale de l'astigmatism induit par la keratoplastie transfixiante a l'aide du keratome arciforme de Hanna. J Fr Ophtalmol 1997;20:360-5

${ }^{232} \mathrm{McNeill}$ JI, Aaen VJ. Long-term results of single continuous suture adjustment to reduce penetrating keratoplasty astigmatism. Cornea 1999;18:19-24

${ }_{213}$ Solomon A, Siganos CS, Frucht-Pery J. Relaxing incision guided by videokeratography for astigmatism after keratoplasty for keratoconus. J Refract Surg 1999; 15:343-8

${ }^{23.1}$ Koay PY, McGhee CN, Crawford GJ. Effect of a standard paired arcuate incision and augmentation sutures on post-keratoplasty astigmatism. J Cataract Refract Surg 2000;26:55361 .

${ }^{235}$ Parisi A, Salchow DJ, Zirm ME, Stieldorf C Laser in situ keratomileusis after automated lamellar keratoplasty and penetrating keratoplasty. J Cataract Refract Surg. 1998;24:6-7. ${ }_{236}$ Arenas E, Maglione A. Laser in situ keratomileusis for astigmatism and myopia after penetrating keratoplasty. J Refract Surg 1997;13:27-32.

${ }_{23}$ Wiesinger-Jendritza B, Knorz MC, Hugger P, Liermann A. Laser in situ keratomileusis assisted by corneal topography. J Cataract Refract Surg 1998;24:166-74.

${ }_{23 \mathrm{~K}}$ Webber SK, Lawless MA, Sutton GL, Rogers CM. LASIK for post penetrating

keratoplasty astigmatism and myopia. Br J Ophthalmol 1999,83:1013-8

239 Donnenfeld ED, Kornstein HS, Amin A, Speaker MD, Seedor JA, Sforza PD, Landrio LM, Perry HD Laser in situ keratomileusis for correction of myopia and astigmatism after penetrating keratoplasty. Ophthalmology 1999;106:1966-74.

?** Guell JL, Gris O, de Muller A, Corcostegui B LASIK for the correction of residual refractive errors from previous surgical procedures. Ophthal Surg Lasers 1999;30;341-9

$2: 11$ Forseto AS, Francesconi CM, Nose RA, Nose W. Laser in situ keratomileusis to correct refractive errors after keratoplasty. J Cataract Refract Surg 1999;25:479-85

212 Spadea L, Mosca L, Balestrazzi E. Effectiveness of LASIK to correct refractive error after penetrating keratoplasty. Ophthalmic Surg Lasers 2000;31:111-20.

${ }^{243}$ Koay PY, McChee CN, Weed KH, Craig JP. Laser in situ keratomileusis for ametropia after penetrating keratoplasty. J Refract Surg 2000;16:140-7.

${ }^{2+1}$ Kwitko S, Marinho DR, Rymer S, Filho SR. Laser in situ keratomileusis after penetrating keratoplasty. J Cataract Refract Surg 2001;27,374-9

2*: Osman A. Two step approach in LASIK following PKP. Eurotimes 2001,6:6-7

${ }^{2 k}$ Eggink FAGJ, Beekhuis WH, Vreugdenhil W. Keratoplastiek en contactlenzen Visus $1991,3: 11-15$

:" Eggink FAGJ, Vreugdenhil W, Beekhuis WH. Therapeutische Kontaktlinsen nach

Keratoplastiek. die Kontaktlinse 1994,28,1/2:5-10

${ }^{2+1}$ Manabe R, Matsuda M, Suda T. Photokeratoscopy in fitting contact lens after penetrating keratoplasty. Br J Ophthalmol 1986;70:55-59.

2*' Genvert GI, Cohen EJ, Arentsen JJ, Laibson PR. Fitting gas-permeable contact lenses after penetrating keratoplasty. Am J of Ophthalmol 1985;99:511-4.

: Speaker MG, Cohen EJ, Edelhauser HF, Clemons CS, Arentsen JJ, Laibson PR, Raskin EM. Effect of gas permeable contact lenses on the endothelium of comeal transplants. Arch Ophthalmol 1991;109:1703-6.

$\rightarrow$ Smiddy WE, Hamburg TR, Krachmer GP, Stark WJ. Visual correction following penetrating keratoplasty. Ophthalmic Surg 1992;23:90-3

$\because$ Wilson SE, Friedman RS, Klyce SD. Contact lens mantpulation of corneal topography after penetrating keratoplasty: A preliminary study CLAO J 1992;18:177-81 


\footnotetext{
${ }^{25.3}$ Weiner BM, Nirankari VS. A new bi-spheric contact lens for severe astigmatism following penetrating keratoplasty. CLAO J 1992;18:81.

${ }^{25.4}$ Lopatynsky M, Cohen EJ, Leavitt KG, Laibson PR. Comeal topography for rigid gas permeable lens fitting after penetrating keratoplasty. CLAO J 1993;19:41-44.

${ }_{25 i}$ Davis LJ. Rigid gas permeable extended wear for the postoperative patient: a review and clinical observations. J Am Optom Assoc 1994,65: 179-86.

${ }^{29}$ Koffler BH, Clements LD, Litteral GL, Smith VM. A new contact lens design for postkeratoplasty patients. CLAO J 1994;20:170-5

3.7 Bourne WM, Shearer DR. Effects of long-term contact lens wear on the endothelium of corneal transplants for keratoconus 10 years after penetrating keratoplasty. CLAO J 1995:21:265-7.

${ }^{25 k}$ Sperber LTD, Lopatynsky MO, Cohen EJ. Corneal topography in contact lens wearers following penetrating keratoplasty. CLAO J 1995;21:183-90.

${ }^{259}$ Szczotka LB, Reinhart W. Computerized videokeratoscopy contact lens software for RGP fitting in a bilateral post-keratoplasty patient: a clinical case report. CLAO J 1995;21:52-6

ztil Gomes JAP, Rapuano CJ, Cohen EJ. Topographic stability and safety of contact lens use after penetrating keratoplasty. CLAO J 1996;22: 64-9

" Lim L, Siow KL, Sakamoto R, Chong Chong JS, Tian Hwee Tan D. Reverse geometry contact lens wear after photorefractive keratectomy, radial keratotomy, or penetrating keratoplasty. Cornea 2000;19:320-4

${ }^{262}$ Smiddy WE, Hamburg TR, Kracher GP, Stark WJ. Keratoconus, contact lens or keratoplasty. Ophthalmology 1988;95:487-92.

${ }^{36.3}$ Ing JJ, Ing $\mathrm{HH}$, Nelson LR, Hodge DO. Ten-year postoperative results of penetrating keratoplasty. Ophthalmology 1998;105:1855-65

${ }_{26.4}$ Matsuda M, MacRae SM, Inaba M, Manabe R. The effect of hard contact lens wear on the keratoconic comeal endothelium after penetrating keratoplasty. Am J Ophthalmol 1989;107:246-51

21, Binder PS, Kopecky L. Fitting the SoftPerm contact lens after keratoplasty. CLAO J 1992;18:170-2.

${ }_{26 i}$ Marshall J, Trokel SL, Rothery S, Krueger RR. Long term healing of the central cornea after photorefractive keratectomy using an excimer laser. Ophthalmology 1988;95:1411-21.

20. Mardelli PG, Piebenga LW, Matta CS, Hyde LL, Gira JG. Corneal endothelial status 12 to 55 months after excimer laser photorefractive keratectomy. Ophthalmology 1995;102:544-9.

${ }^{20}$ Garrison BJ, Srinivasan R. Laser ablation of organic polymers: microscopic models for photochemical and termal processes. J Appl Phys 1985;57:2909-13.

${ }^{26(6)}$ Meier U, Anastasi C, Failla F, Simona F. Die Möglichkeiten der therapeutischen Photokeratektomie mit dem Excimerlaser bei der Behandlung der Schnijder kristalinen Hornhautdystrophie. Klin Monatsbl Augenheilkd 1998;212:405-6.

27 Jones ST, Stauffer LK. Reis Bücklers corneal dystrophy: a clinicopathologic study. Trans Am Acad Ophthalmol Otolaryngol 1970;74:417-26

${ }^{211}$ Rice NS, Ashton N, Jay B, Black RK. Reis Bücklers dystrophy. Br J Ophthalmol 1968:52:577-603.

2 Weidle EG. Klinische und feingewebliche Abgrenzung der Reis-Bücklersschen Hornhautdystrophie. Klin Mbl Augenheilk 1989;194:217-26.

${ }^{271}$ Moller HU. Granular corneal dystrophy Goenouw type I and Reis-Bucklers' corneal dystrophy One entity? Acta Ophthalmol (Copenh) 1989;67:678-84.
} 


\section{Chapter 2}

${ }^{774}$ Munier FL, Korvatska E, Djemai A et al. Kerato-epithelin mutations in four $5 q 31$ linked corneal dystrophies. Nat Genet 1997;15:247-51.

${ }^{2-9}$ Klintworth GK. Advances in the molecular genetics of corneal dystrophies. Am J Ophthalmol 1999,128:747-54.

${ }^{276}$ Hall P. Reis-Bücklers dystrophy. Arch Ophthalmol 1974;92:170-3.

${ }^{277}$ Automated lamellar keratoplasty. American Academy of Ophthalmology. Ophthalmology $1996 ; 103 ; 852-61$

${ }^{27 \times}$ Stark WJ, Chamon W, Kamp MT. Clinical follow-up of 193-nm ArF Excimer laser photokeratectomy. Ophthalmology 1992;99:805-11

${ }_{279}$ McDonnell PJ, Seiler T. Phototherapeutic keratectomy with excimer laser for ReisBückler's corneal dystrophy. Refractive \& Corneal Surg 1992;8:S306*10.

${ }^{280}$ Rogers C, Cohen P, Lawless M. Phototherapeutic keratectomy for Reis Bucklers'corneal dystrophy. Austr New Zealand J Ophthalmol 1993;21:247-50.

${ }^{281}$ Lawless MA, Cohen P, Rogers C. Phototherapeutic keratectomy for Reis-Bückler's dystrophy. Refractive Corneal Surg 1993;9:S96-8.

${ }^{282}$ Hersh PS, Spinak A, Garrana R, Mayers M. Phototherapeutic keratectomy: strategies and results in 12 eyes. Refractive \& Corneal Surg 1993;9:S90-5.

${ }^{283}$ Poirier L, Coulon P, Mortemousque B, Verin Ph. Résultat de la photokératectomie thérapeutique par laser Excimer. J Fr Ophtalmol 1994;17:262-71.

${ }^{28.4}$ Heinz P, Wiegand W, Kroll P. Phototherapeutische Keratectomie bei Rezidiven einer granulären Hornhautdystrophie nach Keratoplastik. Klin Monatsbl Augenheilkd 1995;206: 184-7.

${ }^{285}$ Maloney RK, Thompson V, Ghiselli G, Durrie D, Warring III GA, O'Connell M. A prospective nulticenter trial of excimer laser phototherapeutic keratectomy for corneal vision loss. Am J Ophthalmol 1996;122: 149-60.

${ }^{3 x \times}$ Nassaralla BA, Garbus J, McDonnell PJ. Phototherapeutic keratectomy for granular and lattice corneal dystrophies at 1.5 to 4 years. J Refractive Surg 1996;12:795-800.

${ }^{287}$ Orndahl MJF, Fagerholm PP. Treatment of corneal dystrophies with phototherapeutic keratectomy. J Refractive Surg 1998;14:129-35.

${ }_{285}$ Aouni AE, Briat B, Mayer F, Saragoussi JJ, Abenhaim A, Assouline M, David T, Pouliquen $Y$, Renard G. Dystrophie de Reis-Bückler: photoablation thérapeutique au laser Excimer, J Fr Ophtalmol 1998:21:23-7.

${ }^{289}$ Amano S, Oshika T, Tazawa $\mathrm{X}$, Tsuru T. Long-term follow-up of excimer laser phototherapeutic keratectomy, Jap J Ophthalmol 1999;43:513-6.

${ }^{290}$ Dingh R, Rapuano CJ, Cohen EJ, Laibson PR. Recurrence of corneal dystrophy after excimer laser phototherapeutic keratectomy. Ophthalmology 1999;106:1490-7.

${ }^{291}$ Dighiero P, Ellies P, Legeais JM. Phototherapeutic keratectomy in the treatment of corneal granular dystrophy, Groenouw I. J Fr Ophtalmol 1999;22:176-9.

${ }_{292}$ Kasetsuwan N, Puangsricharern V, Piriyaknok L. Excimer laser phototherapeutic keratectomy for corneal diseases. J Med Assoc Thai 2000;83:474-82.

${ }^{293}$ Stalz JJ, Maguen E, Macy JI. One year results of excimer laser photorefractive keratectomy for myopia. Refract Corneal Surg 1992;8:270-3.

${ }^{294}$ Gaster RN, Binder PS, Coalwell K. Corneal surface ablation by $193 \mathrm{~nm}$ Excimer laser and wound healing in rabbits. Invest Ophthalmol Vis Sci 1989;30:90-7.

${ }^{2 y 5}$ El-Aouni A, Briat B, Mayer F, Saragoussi JJ, Abenhaim A, Assouline M, David T, Pouliquen $Y$, Renard $G$. Dystrophie de Reis-Buckler: photoablation therapeutique au laser excimer. J Fr Ophtalmol 1998;21:23-7 
${ }_{245}$ Amm M, Duncker GIW. Refractive changes after phototherapeutic keratectomy. I Cataract Refract Surg 1997;23:839-44.

${ }^{297}$ Ward MA, Artunduaga G, Thompson KP, Wilson LA, Stulting RD. Phototherapeutic keratectomy for the treatment of nodular subepithelial corneal scars in patients with keratoconus who are contact lens intolerant. CLAO J 1995;21:130-2.

${ }^{296}$ Melles GRJ. Keratotomy incision dimensions and wound healing, Thesis, 1995

Trokel SL, Srinivasan R, Braren B. Excimer laser surgery of the cornea. Am J Ophthalmol 1983;96:710-715.

${ }^{3 * x}$ Marshall J, Trokel SL, Rothery S, Krueger RR. Photoablative reprofiling of the cornea using an excimer laser: photorefractive keratectomy. Lasers in ophthalmology 1986;1:21-48

${ }^{301}$ American Academy of Ophthalmology. Excimer laser photorefractive keratectomy (PRK) for myopia and astigmatism. Ophthalmol 1999;106:422-37.

${ }^{302}$ Munnerlyn CR, Koons SJ, Marshall J. Photorefractive keratectomy: a technique for laser refractive surgery. J Cataract Refract Surg 1988;14:46-52

${ }^{30.3}$ Pop M, Payette Y. Multipass versus single pass photorefractive keratectomy for high myopia using a scanning laser. J Refractive Surg 1999;15:444-50.

3at Coorpender SJ, Klyce SD, McDonald MB, Doubrava MW. Corneal topography of smallbeam tracking excimer laser photorefractive keratectomy. I Cataract Refract Surg 1999;25:675-84

${ }^{315}$ Piebenga L, Matta C, Deitz M, Tauber J, Irvine J, Sabates F. Excimer photorefractive keratectomy for myopia. Ophthalmology 1993;100:1335-45.

${ }^{3 \%}$ Kaluzny JJ, Mrukwa E, Gierek-Ciaciura S. Wyniki Keratotomii Radialnej i

fotokeratektomii refrakcyjnej w ocenie pacjentow. Klin Oczna 1998;100:243-5

${ }^{3177}$ Rowsey JJ, Morley WA. Surgical correction of moderate myopia: which method should you choose? Radial keratotomy will always have a place. Surv Ophthalmol 1998;43:147-56 ${ }_{30}$ Pallikaris IG, Papatzanaki ME, Stathi EZ. Laser in situ keratomileusis. Lasers Surg Med $1990 ; 10: 436-68$

${ }^{309}$ Lim-Bom-Siong R, Valluri S, Gordon M, Pepose J. Efficacy and safety of the ProTek (Vifilcon A) therapeutic soft contact lens after photorefractive keratectomy. Am J Ophthalmol 1998; 12:169-76.

31" Verma S. Marshall J. Control of pain after photorefractive keratectomy. J Refract Surg $1996 ; 12: 358-64$.

"II Langenbucher A, Seitz B, Kus MM, van der Heyd GJ. Topographiegestützte Korrektur von Oberflächenirregularitäten der Hornhaut nit dem Excimerlaser. Klin Monatsbl Agenheilkd 1998;213:132-40.

"Dausch D, Schröder E, Dausch S. Topography-controlled excimer laser photorefractive keratectomy. J Refract Surg 2000;16:13-22.

${ }^{313}$ Boxer Wachler BS, Evans DW, Krueger RR. Advanced visual function testing in LASIK In: Pallikaris IG, Siganos DS, eds. LASIK. Thorofare, NJ: Slack Inc; 1997:325-28.

"1: Lawless MA. Refining visual quality assessment in refractive surgery. J Cataract Refract Sur 1999;25:1031-2.

${ }^{115}$ Mangione CM, Phillips RS, Seddon JM et al Development of the "Activities on Daily

Vision Scale": a measure of visual functional status. Med Care 1992;30:1111-26

${ }^{316}$ Lindstrom RL. The Barraquer lecture: surgical management of myopia-a clinician's perspective. J Refract Surg 1997;13:287-94

${ }^{17} \mathrm{Kim}$ JH, Sah WJ, Hahn TW, Lee YC. Some problems after photorefractive keratectomy. J Refract Surg 1994;10(2):S226-30 


\section{Chapter 2}

${ }^{318}$ Loewenstein A, Lipshitz 1, Varssano D, Lazar M. Complications of excimer laser photorefractive keratectomy for myopia. J Cataract Refract Surg 1997;23:1174-6.

${ }^{314}$ Seiler T, Holschbach A, Derse M. Complications of myopic photorefractive keratectomy with the excimer laser. Ophthalmology 1994;101:153-60.

$3{ }^{33 i}$ Koch DD, Kohnen T, Obstbaum SA, Rosen ES. Format for reporting surgical data. J Cataract Refract Surg 1998;24:285-7.

${ }^{321}$ Waring III GO. Standardized data collection and reporting for refractive surgery. J Refract Corneal Surg 1992;8(S):1-42

${ }^{322}$ Koch DD. How should we analyze astigmatic data? J Cataract Refract Surg 2001;27:1-3

${ }^{323}$ Alpins NA. Vector analysis of astigmatism changes by flattening, steepening, and torque. $J$ Cataract Refract Surg 1997;23:1503-14

${ }^{324}$ Alpins NA. New method of targeting vectors to treat astigmatism. J Cataract Refract Surg 1997;23:65-75.

${ }^{325}$ Alpins NA, Tabin GC, Adams LM, Aldred GF, Kent DG, Taylor HR. Refractive versus corneal changes after photorefractive keratectomy for astigmatism. J Refract Surg $1998 ; 14: 386-96$

${ }^{326}$ Holladay JT, Cravy TV, Koch DD Calculating the surgically induced refractive change following ocular surgery. J Cataract Refract Surg 1992;18:429-43.

${ }^{32}$ Holladay JT, Dudeja DR, Koch DD. Evaluating and reporting astigmatism for individual and aggregate data. J Cataract Refract Surg 1998;24:57-65.

${ }^{728}$ Thibos LN, Wheeler W, Horner D. Power vectors: an application of Fourier analysis to the description and statistical analysis of refractive error. Optom Vis Sci 1997;74:367-75

${ }^{329}$ Naeser K, Behrens JK. Correlation between polar values and vector analysis. J Cataract Refract Surg 1997;23:76-81.

${ }^{3 . k 1}$ Naeser K, Hjortdal JO. Bivariate analysis of surgical induced regular astigmatism.

Matematical analysis and graphical display. Ophthalmic Physiol Opt 1999;19:50-61.

${ }^{3.31}$ Wang Z, Chen J, Yang B. Comparison of laser in situ keratomileusis and photorefractive keratectomy to correct myopia from -1.25 to -6.00 diopters. J Refract Surg 1997;13:528-34

${ }^{132}$ Shah S, Chatterjee A, Smith RJ. Predictability of spherical photorefractive keratectomy for myopia. Ophthalmology 1998;105:2178-85

${ }^{333}$ Pietila J, Makinen P, Pajari S, Uusilato H. Photorefractive keratectomy for -1.25 to -25.0 diopters of myopia. J Refract Surg 1998;14:615-22.

${ }^{33}$ Hadden OB, Ring CP, Morris AT, Elder MJ. Visual, refractive, and subjective outcome after photorefractive keratectomy for myopia of 6 to 10 diopters using Nidek laser. J Cartaract Refract Surg 1999;25:936-42

${ }^{3.35}$ Ahn CS, Clinch TE, Moshirfar M, Weis JR, Hutchinson CB. Initial results of photorefractive and laser in situ keratomileusis performed by one single surgeon. $\mathbf{J}$ Cataract Refract Surg 1999;25:1048-55.

${ }^{336}$ Kapadia MS, Wilson SE. One year results of PRK in low and moderate myopia: fewer than $0.5 \%$ of eyes lose two or more lines of vision. Cornea $2000 ; 19: 180-4$

${ }^{337}$ Pop M, Payette Y. Photorefractive keratectomy versus laser in situ keratomileusis: a control matched study. Ophthalmology 2000;107:251-7.

${ }^{33 *}$ Pirzada WA, Kalaawry H.Laser in situ keratomileusis for myopia of -1 to -3.5 diopters. $\mathbf{J}$ Refract Surg 1997;13:S425-6

${ }^{139}$ Zaldivar R, Davidorf JM, Shultz MC, Oscherow S. Laser in situ keratomileusis for low myopia and astigmatism with a scanning spot excimer laser. J Refract Surg 1997;13:614-9. 
311" Zaldivar R, Davidorf JM, Oscherow S. Laser in situ keratomileusis for myopia from -5.50 to -11.50 diopters with astigmatism. J Refract Surg 1998,14:19-25

311 Salchow DJ, Zirm ME, Stieldorf C, Parisi A. Laser-in-situ-keratomileusis (LASIK) zur Myopie- und Astigmatismuskorrektur. Ophthalmologe 1998;95: 142-7.

${ }^{342}$ Malcionado-Bas A, Onnis R. Results of laser in situ keratomileusis in different degree of myopia, Ophthalmology 1998;105:606-11.

${ }^{343}$ Dulaney DD, Barnet RW, Perkins SA, Keririan GM. Laser in situ keratomileusis for myopia and astigmatism: 6 month results. J Cataract Refract Surg. 1998;24:758-64

${ }^{3+4}$ Carr JD, Stulting RD, Sano Y, Thompson KP, Wiley W, Waring GO III Prospective comparison of single-zone and multizone laser in situ keratomileusis for the correction of low myopia. Ophthalmology 1998;105:1504-11

${ }^{345}$ Montes M, Chayet A, Gomez L, Magallanes R, Robledo N. Laser in situ keratomileusis for myopia of -1.50 to -6.0 diopters. J Refract Surg 1999;1 5: 106-10

${ }^{344}$ Reviglio VE, Luna JD, Rodriguez ML, Garcia FE, Juarez CP. Laser in situ keratomileusis using the LaserSight 200 laser: results of 950 consecutive cases. J Cataract Refract Surg 1999;25: 1029-30.

${ }^{347}$ Gimbel HV, van Westenbrugge JA, Anderson Penno EE, Ferensowicz M, Feinerman GA, Chen R. Simultaneous bilateral laser in situ keratomileusis. Ophthaimology 1999;106:1461-8

${ }_{3116}$ Burrato L, Ferrari M, Rama P. Excimer laser intra-stromal keratomileusis. Am J Ophthalmol 1992;113:291-5.

${ }^{3.47}$ Salah T, Waring GO, El Maghraby A. Excimer laser in situ keratomileusis under a corneal flap for myopia of 2 to 20 diopters. Am J Ophthalmol 1996;121:143-55.

${ }^{3.50}$ Helmy SA, Salah A, Badaway TT. Photorefractive keratectomy and laser in situ

keratomileusis for myopia between 6.00 and 10.00 diopters. J Refract Surg 1996;12:417-21.

${ }^{3.5}$ Applegate RA, Howland HC. Magnification and visual acuity in refractive surgery. Arch Ophthalmol $1993 ; 111: 1335-42$

${ }^{35:}$ Brancato R, Schiavone N, Siano S, Lapucci A, Papucci L, Donnini M, Formigli L, Orlandini SZ, Carella G. Prevention of corneal keratocyte apoptosis after argon fluoride excimer laser irradiation with the free radical scavenger ubiquinone Q10. Eur J Ophthalmol $2000 ; 10: 32-8$

${ }^{353}$ Helena MC, Baerveldt F, Kim WJ, Wilson SE. Keratocyte apoptosis after corneal surgery. Invest Ophthalmol Vis Sci 1998;39:276-83.

${ }_{351}^{5}$ Katlun T, Wiegand W. Haze und Regression nach photorefractiver Keratectomie (PRK) Ophthalmologe 2000;97:487-90.

${ }^{355}$ Moller-Pedersen T, Cavanagh HD, Petrol! WM, Jester JV. Stromal wound healing explains refractive instability and haze development after photorefractive keratectomy: a 1-year confocal microscopy study. Ophthalmology 2000;107:1235-45.

${ }^{356}$ Lipshitz I, Loewenstein A, Varssano D, Lazar M. Late onset corneal haze after photorefractive keratectomy for moderate and high myopia. Ophthalmology 1997;104:36974.

${ }^{35.7}$ Kremer I, Kaplan A, Novikov I, Blumenthal M. Patterns of late corneal scarring after photorefractive keratectomy in high and severe myopia. Ophthalmology 1999;106:467-73.

${ }^{35 *}$ Krueger RR, Saedy NF, McDonnell PJ. Clinical analysis of steep central islands after excimer laser photorefractive keratectomy. Arch Ophthalmol 1996;114:377-81.

${ }^{159}$ Noack J, Tonnies R, Hohla K. Influence of ablation plume dynamics on the formation of central islands in excimer laser photorefractive keratectomy. Ophthalmology 1997;104:82330. 
3rin Oshika T, Klyce SD, Smolek MK, McDonald MB. Corneal hydration and central island after excimer laser photorefractive keratectomy. J Cataract Refract Surg 1998;24:1575-80. ${ }^{361}$ Levin S, Carson CA, Garrett SK, Taylor HR. Prevalence of central islands after excimer refractive surgery. J Cataract Refract Surg 1995;21:21-6.

36. Tsai YY, Lin JM. Natural history of central islands after laser in situ keratomileusis. J Cataract Refract Surg 2000;26:853-8.

${ }^{363} \mathrm{~L}$ Lafond $\mathrm{G}$, Solomon L. Retreatment of central islands after photorefractive keratectomy. $J$ Cataract Refract Surg 1999;25:188-96

${ }^{364}$ Vaipayee RB, McCarty CA, Alderd G, Taylor HR. The Melbourne excimer laser group Overcorrection after excimer laser treatment of myopia and myopic astigmatism. Arch Ophthalmol 1996;114:252-6

${ }^{365}$ Alio JL, Artola A, Claramonte PJ, Ayala MJ, Sanchez SP. Complications of photorefractive keratectomy for myopia: two year follow-up of 3000 cases. J Cataract Refract Surg 1998;24:619-26

${ }_{36 \pi}$ Lohmann CP, Reischl U, Marshall J. Regression and epithelial hyperplasia after myopic photorefractive keratectomy in a human cornea. J Cataract Refract Surg 1999;25:712-5.

${ }^{367}$ Beak T, Lee K, Kagaya F, Tomidokoro A, Amano S, Oshika T. Factors affecting the forward shift of posterior corneal surface after laser in situ keratomileusis. Ophthalmology 2001;108:317-20.

${ }^{368}$ Chayet AS, Assil KK, Montes M, Espinosa-Lagana M, Castellanos A, Tsioulias G.

Regression and its mechanism after laser in situ keratomileusis in moderate and high myopia. Ophthalmology 1998;105:1194-9.

${ }^{369}$ Lohmann CP, Guell JL. Regression after LASIK for the treatment of myopia: the role of the corneal epithelium. Semin Ophthalomol 1998;13:79-82.

${ }^{37 \%}$ Spadea L, Fasciani R, Necozione S, Balestrazzi E. Role of the corneal epithelium in refractive changes following laser in situ keratomileusis for high myopia. J Refract Surg 2000;16:133-9.

${ }^{371}$ Maloney RK. Comeal topography and optical zone location in PRK. J Refract Corneal Surg 1990; 6:363-71.

${ }^{372}$ McDonnell PJ, McClusky DJ, Garbus JJ. Corneal topography and fluctuating visual acuity after radial keratotomy. Ophthalmology 1989;96: 665-70.

${ }^{373}$ Maguire LJ, Bourne WM. A multifocal lens effect as a complication of radial keratotomy. Refract Corneal Surg 1989;5:394-9.

${ }^{37.4}$ Wilson SE, Klyce SD, McDonald MB. Changes in corneal topography after excimer laser photorefractive keratectomy for myopia. Ophthalmology 1991;98:1338-47.

${ }^{375}$ Martinez CE, Applegate RA, Howland HC. Changes in corneal aberration structure after photorefractive keratectomy. Invest Ophthalmol Vis Sci 1996;37:\$933

${ }^{376}$ Brint SF, Ostrick DM, Fisher Q. Six-month results of the multicenter phase I study of excimer laser myopic keratomileusis. J Cataract Refract Surg 1994;20,610-5.

${ }^{377}$ Hersh PS, Shah SI. Corneal topography of excimer laser photorefractive keratectomy using a 6-mm beam diameter. Summit PRK Topography Study Group. Ophthalmology 1997; 104: 1333-42.

${ }^{378}$ Fagerholm P. Wound healing after photorefractive keratectomy. J Cataract Refract Surg 2000;26:432-47.

${ }^{370}$ Seiler T, Holschbach A, Derse M. Complications of myopic photorefractive keratectomy with the excimer laser. Ophthalmol 1994;101:153-60. 


\footnotetext{
${ }^{380}$ Binder PS. Optical problems following refractive surgery. Ophthalmology 1986:93:739. 45

${ }^{3 * 1}$ Keller PR, van Saarloos PP, Yellachich D. Computer simulation of centration effects on corneal-topography analysis of excimer laser photorefractive keratectomy ablations. Cornea 1997; 16:54-63

${ }^{382}$ Cavanaugh TB, Durrie DS, Riedel SM, Hunkeler JD, Lesher MP. Centration of excimer laser photorefractive keratectomy relative to the pupil. J Cataract Refract Surg 1993;19:144-8.

${ }^{3 \times 3}$ Lin DTC Corneal topographic analysis after photorefractive keratectomy. Ophthalmology 1994,101:1432-9
}

${ }^{38.4}$ Tally AR, Hardten DR, Sher NA, Kim MS, Doughman DJ, Carpel E, Ostrov CS, Lane SS, Parker P, Lindstrom RL, Results one year after using the 193-nm excimer laser for photorefractive keratectomy in mild to moderate myopia. Am J Ophthalmol 1994; 1 18 304-11. ${ }^{3 \times .}$ Schwartz BH, Hersh PS. Corneal topography of phase III excimer laser photorefractive keratectomy. Ophthalmology 1995;102,951-62.

${ }^{3}$ s. Almendral D, Waller SG, Talamo JH. Assessment of ablation zone centration after photorefractive keratectomy using a vector center of mass formula. J Refract Surg $1996 ; 12: 483-91$.

${ }^{3 \mathrm{~K}^{\prime}}$ Aktunç R, Aktunç T. Centration of excimer laser photorefractive keratectomy and changes in astigmatism. J Refract Surg 1996; 12:S268-71.

${ }^{3 \times x}$ Deitz MR, Piebenga LW, Matta CS, Tauber J, Anello RD, DeLuca M. Ablation zone centration after photorefractive keratectomy and its effect on visual outcome. J Cataract Refract Surg 1996;22:696-701.

${ }^{3 k^{\prime \prime}}$ Mulhern MG, Foley-Nolan A, O'Keefe M, Condon PI Topographical analysis of ablation centration after excimer laser photorefractive keratectomy and laser in situ keratomileusis for high myopia. J Cataract Refract Surg 1997;23:488-94.

${ }^{15}$ Lee JB, Jung JI, Chu YK, Lee JH, Kim EK. Analysis of the factors affecting decentration in photorefractive keratectomy and laser in situ keratomileusis for myopia. Yonsei Med J 1999;40:221-5.

${ }^{3 \prime 1}$ Keller PR, McGhee CNJ, Weed KH. Fourier analysis of corneal topography data after photorefractive keratectomy. J Cataract Refractive Surg 1998;24:1447-55.

"Cavanaugh TB, Durrie DS, Reidel SM. Topographical analysis of the centration of excimer laser photorefractive keratectomy. J Cataract Refract Surg 1993;19:S136.

${ }^{314}$ Hersh PS, Schwartz-Goldstein BH. Corneal topography of phase III excimer laser photorefractive keratectomy: Optical zone centration analysis. Ophthalmol 1995;102:951-62.

${ }^{3} w_{1}$ Milea D, Burillon C. Ecimer laser photorefractive keratectomy in myopic eyes with corectopia. J Cataract Refract Surg 1999;25:709-11

${ }^{3}{ }^{4} \mathrm{~K}$ Klyce SD, Smolek MK. Corneal topography of excimer laser photorefractive keratectomy. J Cataract Refract Surg 1993;19(suppl): 122-30.

${ }^{3 \%}$ Azar DT, Yeh PC. Corneal topographic evaluation of decentration in photorefractive keratectomy: treatment displacement vs intraoperative drift. Am J Ophthalmol 1997;124:31220 .

"wh Tsai YY, Lin JM. Ablation centration after active eye-tracker-assisted photorefractive keratectomy and laser in situ keratomileusis. J Cataract Refract Surg 2000;26:28-34.

${ }^{198}$ Schwiegerling J, Snyder RW. Corneal ablation patterns to correct for spherical aberration in photorefractive keratectomy. J Cataract Refract Surg 2000;26:214-21. 
${ }^{199}$ Hersh PS, Steinert RF, Brint SF. Photorefractive keratectomy versus laser in situ keratomileusis: comparison of optical side effects. Summit PRK-LASIK Study Group. Ophthalmology 2000;107:925-33

"Witi Verdon W, Bullimore M, Maloney RK. Visual performance after photorefractive keratectomy. A prospective study. Arch Ophthalmol 1996;114:1465-1472

*in Roberts CW, Koester CJ. Optical zone diameters for photorefractive corneal surgery. Invest Ophthalmol Vis Sci 1993;34:2275-2281.

*12 Mulhern MG, Foley-Nolan A, O'Keefe M, Condon PI. Topographical analysis of ablation centration after excimer laser photorefractive keratectomy and laser in situ keratomileusis for high myopia. J Cataract Refract Surg 1997;23:488-94.

${ }^{4113}$ O'Brart DP, Lohmann CP, Fitzke FW. Night vision after excimer laser photorefractive keratectomy: haze and halos. Eur J Ophthalmol 1994;4:43-51

${ }^{*}$ Far Fah SG, Azar DT, Gurdal C, Wong J. Laser in situ keratomileusis: literature review of a developing technique. J Cat Refract Surg 1998;24:989-1006.

twis Brunette I, Gresset J, Boivin JF, Pop M, Thompson P, Lafond GP, Makni H. Functional outcome and satisfaction after photorefractive keratectomy. Part 2: survey of 690 patients. Ophthalmology 2000;107:1790-6

${ }^{4}$ Mr Mrochen M, Kaemmer M, Mierdel P, Seiler T. Increased higher-order optical aberrations after laser refractive surgery. A problem of subclinical decentration. J Cataract Refract Surg 2001;27:362-9.

"117 Blanckaert J, Sallet G. Lasik learning curve: Clinical study of 300 myopic eyes. Bull Soc belge Ophtalmol 1998;268:7-12

*klk Joo CK, Kim TG. Corneal perforation during laser in situ keratomileusis. J Cataract Refract Surg 1999;25:1165-7.

fii) Leung AT, Rao SK, Cheng AC, Yu EW, Fan DS, Lam DS. Pathogenesis and management of laser in situ keratomileusis flap buttonhole. J Cataract Refract Surg 2000;26:358-62.

"Tham VM, Maloney RK. Microkeratome complications of laser in situ keratomileusis Ophthalmology 2000; 107:920-4

"II Stulting RD, Carr JD, Thompson KP. Complications of laser in situ keratomileusis for the correction of myopia. Ophthalmology 1999;106:13-20.

${ }^{112}$ Knorz MC, Jendritza B, Hugger P, Liermann A. Komplikationen of laser in situ keratomileusis (LASIK). Der Ophthalmologe 1999;96:503-8

${ }^{113}$ Lin RT, Maloney RK. Flap complications associated with lamellar refractive surgery. Am J Ophthalmol 1999;127:129-36.

${ }^{114}$ Walker MB, Wilson SE. Lower intraoperative flap complication rate with the Hansatome microkeratome compared to the automated corneal shaper. J Refract Surg 2000;16:79-82.

${ }^{415}$ Geggel HS, Talley AR. Delayed onset keratectasia following laser in situ keratomileusis. J Cataract Refract Surg 1999;25:582-6.

${ }^{116}$ Muravchik J. Keratectasia after LASIK. J Cataract Refract Surg 2000;26:029-30

${ }^{117}$ Joo CK, Kim TG. Corneal ectasia detected after laser in situ keratomileusis for correction of less than - 12 diopters of myopia. J Cataract Refract Surg 2000;26:292-5

${ }^{418}$ Wang $Z$, Chen J, Yang B. Posterior corneal surface topographic changes after laser in situ keratomileusis are related to residual corneal bed thickness. Ophthalmology 1999;106:406-10

${ }^{419} \mathrm{Schmitt}$ BCF, Lesage C, Arnaud B. Keratectasia induced by laser in situ keratomileusis in keratoconus. J Refract Surg 2000;16:368-70

${ }^{42}$ Speicher L, Gottinger W. Progressive Keratektasie nach Laser-in-situ-Keratomileusis (LASIK) Klin Monatsbl Augenheilkd 1998;213:247-51. 


\section{Review of the literature}

\footnotetext{
*21 Lemley HL, Chodosh J, Wolf TC, Bogie CP, Hawkins TC. Partial dislocation of laser in situ keratomileusis flap by air bag injury. J Refractive Surg 2000;16:373-4.

$1=$ Chaudhry NA, Smiddy WE. Displacement of corneal cap during vitrectomy in a post-lasik eye Retina 1998;554-5.

${ }^{427}$ Gimbel HV, Penno EE, van Westenbrugge JA, Ferensowicz M, Furlong MT. Incidence and management of intraoperative and early postoperative complications in 1000 consecutive laser in situ keratomileusis cases. Ophthalmology 1999;106: 1455-7.

${ }^{224}$ Steinert RF, McColgin AZ, White A, Horsburgh GM. Diffuse interface keratitis after laser in situ keratomileusis (LASIK): a nonspecific syndrome. Am J Ophthalmol 2000;129:380-1. ${ }^{125}$ Chung MS, Goldstein MH, Driebe WT, Schwartz B. Fungal keratitis after laser in situ keratomileusis: a case report Cornea 2000;19:236-7

426 Leung AT, Rao SK, Lam DS. Traumatic partial unfolding of laser in situ keratomileusis flap with severe epithelial ingrowth. J Cataract Refract Surg 2000;26:135-9.

$42=$ Holland SP, Srivannaboon S, Reinstein DZ. Avoiding serious corneal complications of laser assisted in situ keratomileusis and photorefractive keratectomy. Ophthalmology 2000;107:640-52

${ }^{42 x}$ Wilson SE, Klyce SD. Screening for corneal topographic abnormalities before refractive surgery. Ophthalmology 1994,101:147-52.

${ }_{425}$ Klyce SD, Smolek MK. Corneal topography of excimer laser photorefractive keratectomy. J Cataract Refract Surg 1993, $\lg ($ suppl): 122

${ }^{436}$ Manche EE, Maloney RK, Smith RJ. Treatment of topographic central islands following refractive surgery. J Cataract Refract Surg 1998;24:464-70.

${ }^{431}$ Rachid MD, Yoo SH, Azar DT. Phototherapeutic keratectomy for decentration and central islands after photorefractive keratectomy. Ophthalmology 2001;108:545-52.

${ }^{432}$ Gartry DS, Larkin DF, Hill AR, Ficker LA, Steele AD. Retreatment for significant regression after excimer laser photorefractive keratectomy. A prospective, randomized, masked trial Ophthalmology 1998;105:131-41.

${ }^{433}$ Rozsival P, Feuermannova A. Retreatment after photorefractive keratectomy for low myopia. Ophthalmology 1998;105:1189-93.

${ }^{4334}$ Higa $\mathrm{H}$, Couper T, Robinson DI, Taylor HR. Multiple photorefractive keratectomy retreatments for myopia. J Refractive Surg 1998;14:123-8.

${ }^{435}$ Vorotnikova EK, Kourenkov VV, Polunin GS. Retreatment of regression after photorefractive keratectomy for myopia. J Refrect Surg 1998 14(2 suppl):S197-8.

${ }^{436}$ Higa H, Couper T, Robinson DI, Taylor HR. Multiple photorefractive keratectomy retreatments for myopia. J Refract Surg 1998;14:123-8.

${ }^{437}$ Perez-Santonja JJ, Ayala MJ, Sakla HF, Ruiz-Moreno JM, Alio JL. Retreatment after laser in situ keratomileusis. Ophthalmology 1999;106:21-8.

${ }^{438}$ Durrie DS, Aziz AA. Lift-flap retreatment after laser in situ keratomileusis. J Refractive Surg 1999;15:150-3

${ }_{4.39}$ Zadok D, Maskaleris G, Garcia V, Shah S, Montes M, Chayet A. Outcomes of retreatment after laser in situ keratomileusis. Ophthalmolgy 1999;106:2391-4.

${ }^{4 * 0}$ Febbraro JL, Buzard KA, Friedlander MH. Re-operations after myopic laser in situ keratomileusis. J Cataract Refract Surg 2000;26:41-8.

${ }^{441}$ Lyle WA, Jin GJC. Retreatment after initial laser in situ keratomileusis. J Cataract Refract Surg 2000;26:650-9.
} 


\section{Chapter 2}

442 Gartry DS, Larkin DFP, Flaxel CJ. Retreatment for significant regression following excimer laser photorefractive keratectomy (PRK) - a randomized, double-masked trial. Invest Ophthalmol Vis Sci 1995;36:S190

${ }^{4.3}$ Alkara N, Genth U, Seiler T. Diametral ablation-a technique to manage decentered photorefractive keratectomy for myopia. J Refract Surg 1999;15:436-40.

${ }^{444}$ Lim-Bon-Siong R, Williams JM, Steinert RF, Pepose JS. Retreatment of decentered excimer photorefractive keratectomy ablations. Am J Ophthalmol 1997;123:122-4.

${ }_{445}$ Alessio G, Boscia F, La Tegola MG, Sborgia C. Topographic-driven photorefractive keratectomy. Ophthalmology 2000;107: 1578-87.

${ }^{446}$ Knorz MC, Jendritza B. Topographically-guided laser in situ keratomileusis to treat corneal irregularities. Ophthalmol 2000;107:1138-43.

\$47 Pallikaris IG, Panagopoulou SI, Katsanevaki VJ. The PALM Technique: Photo-ablated lenticular modulator. Pallikaris IG, Siganos DS eds. LASIK. Thorofare, NJ: Slack Inc; 1997:227-8.

${ }^{*} * 8$ Munoz G, Alio JL, Perez-Santonja JJ, Attia WH, Successful treatment of severe wrinkled corneal flap after laser in situ keratomileusis with deionized water. Am J Ophthalmol 2000;129:91-2

${ }^{419}$ Castillo A, Diaz-Valle D, Gutierrez AR, Toledano N, Romero F. Peripheral flap melt after laser in situ keratomileusis. J Refract Surg 1998;14:61-3

${ }_{450}^{40}$ Reinstein DZ, Silverman RH, Raevsky T, Simoni GJ, Lloyd HO, Najati DJ, Rondeau MJ, Coleman DJ. Arc-scanning very high-frequency digital ultrasound for 3D pachymetric mapping of the corneal epithelium and stroma in situ keratomileusis. J Refract Surg $2000 ; 16: 414-30$

${ }^{451}$ Stodulka P, Vaculik J, Lichnovsky V. Measurement of adhesion of the corneal lamella to the stroma in early postoperative period after microkeratomy. Cesk Slov Oftalmol 1999;55:367-71.

${ }^{452}$ Kato T, Nakayasu K, Hosoda Y, Watanabe Y, Kanai A. Corneal wound healing following laser in situ keratomileusis (LASIK); a histopathological study in rabbits

${ }^{453}$ Reinstein DZ, Silverman RH, Sutton HF, Coleman DJ. Very high-frequency ultrasound corneal analysis identifies anatomic correlates of lamellar refractive surgery anatomic diagnose in lamellar surgery. Ophthalmology 1999;106:474-82.

${ }^{15.4} \mathrm{Lin} \mathrm{RT}$, Maloney RK. Flap complications associated with lamellar refractive surgery. Am $\mathrm{J}$ of Ophthalmol 1999;127:202-204

${ }^{455}$ Gimbel HV, Anderson Penno EE, van Westenbrugge JA, Ferensowicz M, Furlong MT. Incidence and management of intraoperative and early postoperative complications in 1000 consecutive laser in situ keratomileusis cases. Ophthalmology 1998;105:1839-1847

${ }^{45 i}$ Astin CLK. Contact lens fitting after photorefractive keratectomy: a comparison of two groups of patients. Ophthal Physiol Opt 1995;15:371-4.

${ }^{457}$ Astin CLK. Contact lens fitting post refractive surgery. In: Contact lens practice, Chapman \& Hall, London, Vol 36, pp 843-54 (1994).

${ }^{458}$ Schipper I, Businger U, Pfarrer R. Fitting contact lenses after excimer laser photorefractive keratectomy for myopia. CLAO J 1995;21:281-4.

${ }^{459}$ Astin CLK, Gartry DS, Steele AD. Contact lens fitting after photorefractive keratectomy. $\mathrm{Br} J$ Ophthalmol 1996;80:597-603.

${ }^{460}$ Lim L, Siow KL, Chong JSC, Tan DTH. Contact lens wear after photorefractive keratectomy: comparison between rigid gas permeable and soft contact lenses. CLAO J 1999;25:222-7 


\section{Review of the literature}

${ }^{46}$ Chou AC, Swinger CA, Cogger SK. Fitting contact lenses after myopic keratomileusis. J Cataract Refract Surg 1999:25:508-13.

162 Szczotka LB, Aronsky M. Contact lenses after LASIK J Am Optometric Ass 1998;69:77584.

${ }^{46.3}$ Zadnik K. Contact lens management of patients who have had unsuccessful refractive surgery. Curr Opin Ophthalmol 1999;10:260-3.

${ }^{16.1}$ Lee AM, Kastl PR. Rigid gas permeable contact lens fitting after radial keratotomy. CLAO J 1998;24:33-35

465: Eggink FAGJ, Beekhuis WH. Contact lens fitting following radial keratotomy and other relaxing incisions. Contactologia 1989;11:164-8. 


\title{
A new technique for rigid gas permeable contact lens fitting following penetrating keratoplasty
}

\author{
Fred A.G.J. Eggink
}

Rudy M.M.A. Nuijts M.D., Ph.D

Academic Hospital Maastricht, Department of Ophthalmology Acta Ophthalmol Scand 2001; 79:2+5-50.

Supported in part by a grant of the Department of Ophthalmology, University Maastricht. 


\section{ABSTRACT}

Purpose: To evaluate a new rigid gas permeable contact lens fitting technique following penetrating keratoplasty.

Methods: For the correction of postoperative anisometropia or astigmatism, a rigid gas permeable, tetra-curve contact lens with a overall diameter of $12.0 \mathrm{~mm}$ and a back optic zone diameter of $8.5 \mathrm{~mm}$ was fitted in 36 eyes of 33 patients, 7 months after penetrating keratoplasty. The contact lens back optic zone radius was selected using the videokeratography values over the elevated edges of the transplant wound (with the sutures in place). Graft clarity, visual outcome, and corneal topography were evaluated up to 3 years after surgery at intervals of 6 months.

Results: Throughout the follow-up period (range $6-36$, mean 19.3 \pm sd 11.8 months), all grafts remained clear. Mean contact lens daily wearing time averaged 13.6 ( \pm sd 4.7) hours. Mean best-corrected visual acuity improved from $+0.36( \pm$ sd 0.18 ) LogMAR with spectacles to +0.11 ( \pm sd 0.11) LogMAR with contact lenses $(p<0.0001)$. One patient was excluded from the study due to a lack on motivation and one had an adverse reaction on the stitches.

Conclusions: To improve the visual performance following penetrating keratoplasty, the described fitting technique, guided by videokeratograph, eased selection of the back optic zone radius of the initial trial lens. The large diameter contact lenses with a tetra-curve design were well tolerated in all patients during more than 13 hours daily. 


\section{INTRODUCTION}

Penetrating keratoplasty surgical techniques have advanced significantly in the last decade (Ing et al. 1998; McNeill \& Aaen 1999; Shimazaki \& Tsubota 1997) and are still improving (Karabatsas et al. 1998; Boderie et al. 1999). The first years after surgery, when the sutures are in place, in many instances visual acuity outcome is disappointing due to postoperative wound swelling, tension of the stitches on the graft tissue, anisometropia and irregular astigmatism. A number of approaches have been taken to reduce irregular astigmatism, including the use of suture adjustment, selective suture removal and, occasionally, refractive surgery (Solomon et al. 1999; Yoshida et al 1999).

The non-surgical approaches to the management of post-penetrating keratoplasty astigmatism include the following: spectacles, rigid gas permeable (RGP) or soft toric contact lenses, contact lenses and spectacle combination, a piggyback system (a combination of soft and rigid contact lenses), and hybrid lenses (Beekhuis et al. 1991; Eggink et al. 1994; Vreugdenhil et al. 1994; Binder \& Kopecky 1992).

Most post-penetrating keratoplasty patients have an irregular astigmatic cornea during the years when the sutures are in place. An RGP lens may be the correction of first choice, since this type of lens provides good visual acuity, corrects high degrees of regular and irregular astigmatism and has high oxygen permeability.

For unoperated corneas, most contact lens fitting methods use keratometry values in combination with the fluorescein pattern for selection of the back optic zone radius (BOZR) of the initial trial lens. After keratoplasty, the central keratometry values may not be representative for the entire corneal surface area, as in virgin corneas (Shimazaki \& Tsubota 1997; Karabatsas et al 1999). In fact, the radii within the central $3.2 \mathrm{~mm}$ optical zone of a transplanted cornea often show no correlation with the radii in more peripheral areas of the same cornea. A good contact lens fit depends on the best possible overall support of the contact lens across the cornea. Therefore, in transplanted corneas with irregular donor-and-host corneal surfaces, videotopography ring segments in combination with the color map provide a better insight into the entire postoperative corneal contour than central keratometry (Lopatynsky et al. 1993; Spreber et al. 1995). More detailed analysis of the videotopography map may further facilitate the selection of the base curve, and the entire fitting procedure (Szczotka \& Reinhart 1995).

The purpose of the study was to evaluate a new RGP contact lens fitting technique following penetrating keratoplasty, with the sutures in place, in which the back optic zone radius was selected according to the videotopographic values over the transplant wound (Figure 3-1). 


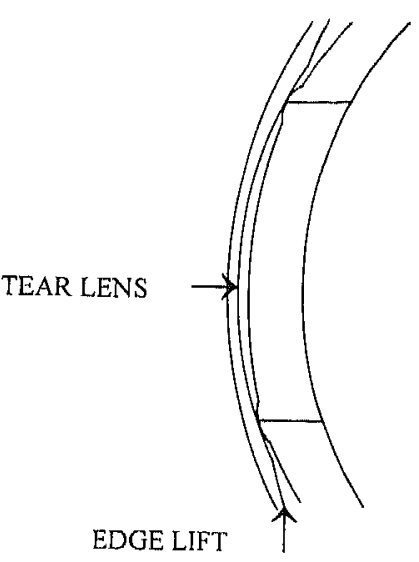

EDGE LIFT
Figure 3-1.

The swollen wound edges in a penetrating keratoplasty are used for contact lens alignment. This creates a tear-film compartment between the back surface of the contact lens and the operated cornea, which neutralizes the corneal surface and replaces it optically with a new surface shaped by the concavity of the contact lens

\section{MATERIAL AND METHODS}

Between 1994 and 1999, 220 eyes underwent penetrating keratoplasty by one single surgeon (RN) at the department of ophthalmology of our hospital. Indications for operation are mentioned in Table 3-1. 33 patients, 36 eyes (16.4\%) were referred to the contact lens unit of our hospital for contact lens fitting, $6.9 \pm$ sd 1.79 months after surgery. Twenty-four patients had an (irregular) astigmatism of 4 diopters or more, and 12 had an anisometropia of 4 $D$ or more. The surgical technique has been described elsewhere (Ing et al. 1997).

Both the videotopography (Alcon Eye Map, Alcon Laboratory inc. Software Version 5.50.03) ring map and the color map were used to determine the dioptric values displayed over the circular transplant wound. The corneal radius of the most regular ring segment, displayed over at least two clock hours at the inner side of the elevated wound ridge was used to select the initial trial lens with an identical back optic zone radius. When there were two or more regular ring segments over two clock hours visible on the ring map, we decided to choose the ring segment with a corresponding radius nearest at the $7.70 \mathrm{~mm}$, the radius of the normal eye. (Example: region 1 had a radius of $9.20 \mathrm{~mm}$; region 2 had a radius of $8.60 \mathrm{~mm}$; we choose a back optic zone radius of the first trial lens of $8.60 \mathrm{~mm}$ ). The center of the elevated wound ridge is very flat and less useful for selection of the contact lens back optic zone radius but serves excellently as contact lens bearing zone. Peripherally to the elevated wound ridge, the topographic ring segments are discarded by the software.

We used the tangential topographic maps, which more closely represent true curvature instead of power.

The tetra-curved trial set we used was designed by one of us (FE) and consisted of lenses with a back optic zone diameter of $8.5 \mathrm{~mm}$. 
RGP contact lens fitting technique after penetrating keratoplasty

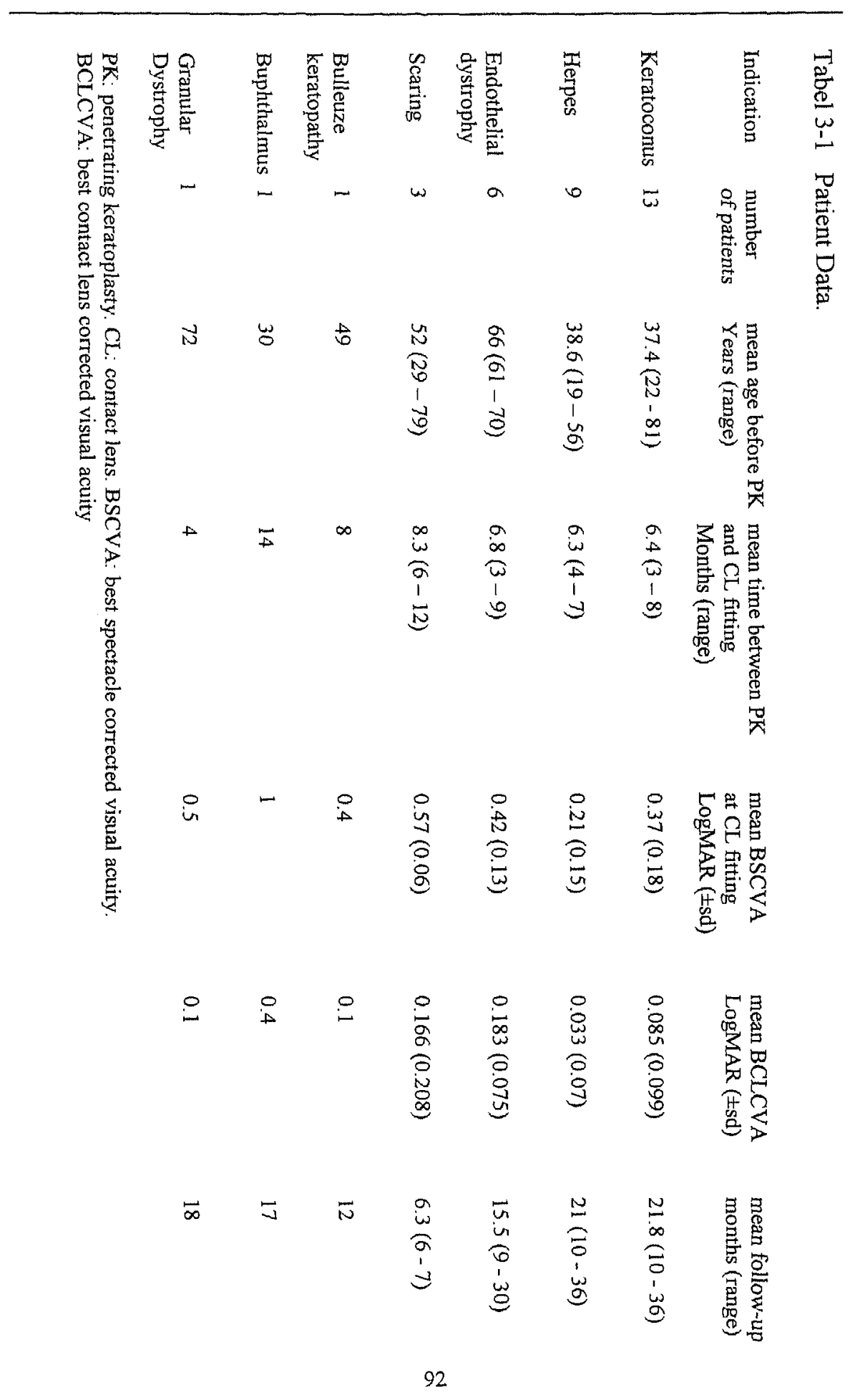




\section{Chapter 3}

The first peripheral curve was $0.5 \mathrm{~mm}$ flatter than the back optic zone radius and had a diameter of $10.5 \mathrm{~mm}$. The second peripheral curve was $1.5 \mathrm{~mm}$ flatter than the back optic zone radius and had an overall diameter of $12.0 \mathrm{~mm}$. The edge radius was $12.5 \mathrm{~mm}$. All transitions were soft blended. In all cases we used a very high Dk contact lens material to avoid corneal edema such as Boston XO with a Dk of 100 (Polymer Technology Corp) or FluoroPerm 151 with a Dk of 151 (Paragon Vision Sciences). The lenses prescribed are custom-made lenses and can be manufactured by any contact lens laboratory.

Before, and six months after contact lens fitting, best spectacle corrected visual acuity, best contact lens corrected visual acuity, both performed according to standard clinical techniques, slit lamp examination, and videotopography were performed. Visual acuity was measured using a high contrast Vector Vision LogMAR chart (Dayton, Ohio, USA). Statistical analysis was performed using the paired Student's t-test.

\section{Case report}

A 24 year-old male had bilateral keratoconus and became RGP contact lens intolerant in his left eye because of comeal ectasia. His left eye had a preoperative visual acuity of + 0.5 LogMAR (20/63 converted to Snellen equivalent) with a contact lens. Four months after penetrating keratoplasty, he was referred to the contact lens unit because of 4.5D of irregular astigmatism. Best spectacle corrected visual acuity of his right eye was +0.2 LogMAR (20/32) with Sph $-0.5 \mathrm{C}-4.75 \times 125^{\circ}$. Slit lamp examination showed a wellcentered, clear penetrating transplant with one running suture and six fixating sutures in situ. On the videotopographic ring map (Figure 3-2 left) the ring segments at the inner side of the elevated wound edge from $1-3$, and from 5 7 o'clock were displayed. Both ring segments were regular over two clock hours and useful for the calculation of the contact lens base curve. The corresponding radius at the inner side of the elevated wound edge, $3.08 \mathrm{~mm}$ out of the visual axis, was $41.68 \mathrm{D}$ (radius $=8.10 \mathrm{~mm}$ ). We indicated this region on the color code map (Figure $3-2$ right), at the $21^{\circ}$ axis by the cursor. 


\section{RGP contact lens fitting technique after penetrating keratoplasty}
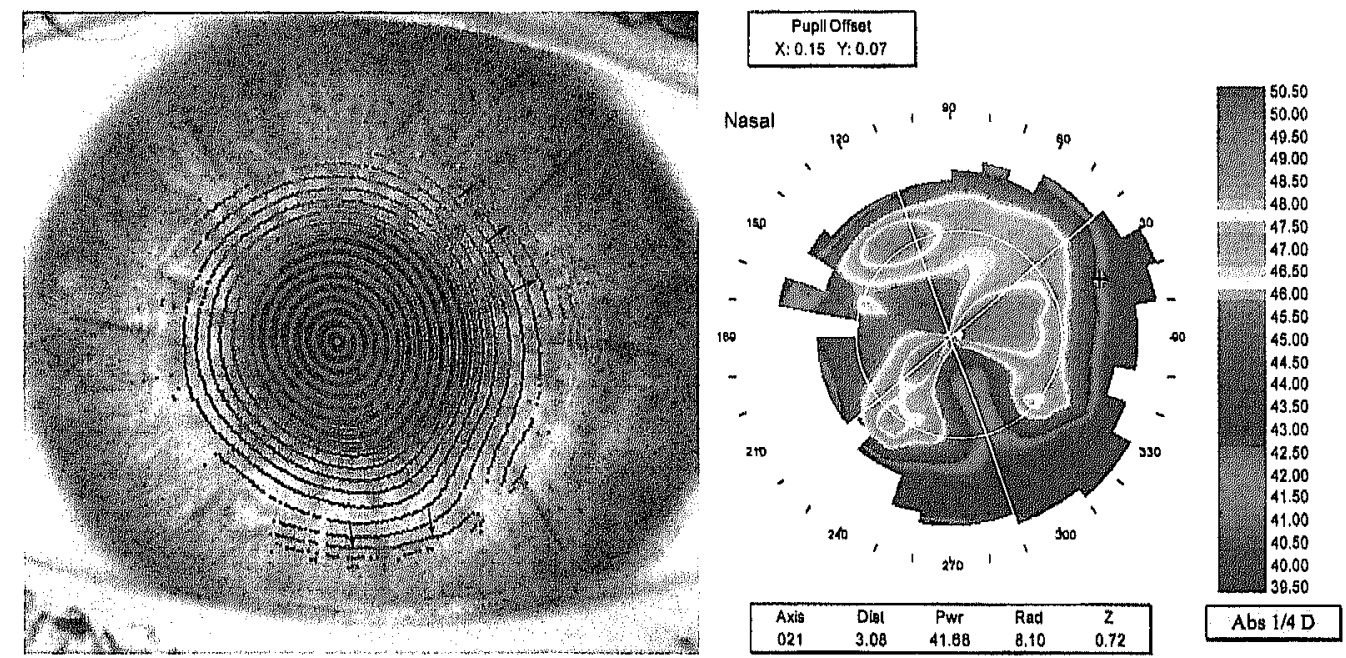

Figure 3-2 left hand-side the ring segments of the topographical image of the described case The running suture and six fixating sutures are in situ. The peripheral ring segments over the wound ridge are picked-up by the system over two clock hours at $1-30^{\prime}$ 'clock and in the $5-$ 7 o'clock region (arrow). The green dots are the tangential measured points. On the $1-3$ o'clock area, we selected the back optic zone radius of the trial lens. Figure 3-2 right handside: topographical finding of the described case. The blue colored region with a refractive power of $41.68 \mathrm{D}$ is the translation of the tangential measured points of figure $3-2$ left. The Dioptric power is pointed out by the cursor, $3.08 \mathrm{~mm}$ out of the visual axis. The back optic zone radius of the trial-lens is $8.10 \mathrm{~mm}$. The $5-7$ o'clock area has the same Dioptric power in 280 degree, $2.42 \mathrm{~mm}$ out of the visual axis (not pointed out by the cursor).

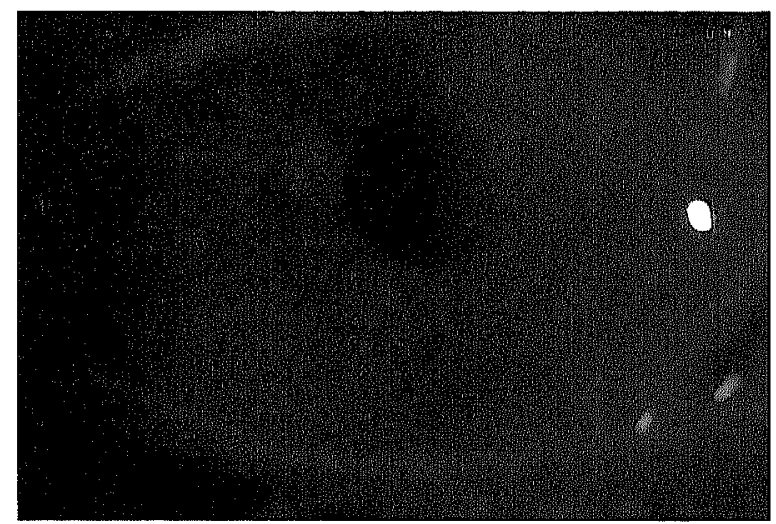

Figure 3-3

The fluorescein pattern of the described case. 


\section{Chapter 3}

Hence, an initial trial-lens was chosen with a back optic zone radius of $8.10 \mathrm{~mm}$ i.e. a radius identical to the area displayed over the wound, with an optical zone diameter of $8.5 \mathrm{~mm}$, Sph $+0.50 \mathrm{D}$ and a diameter of $12.0 \mathrm{~mm}$. The fluorescein pattern is presented in Figure 3-3. The visual acuity with the contact lens was -0.10 LogMAR (20/16). Daily wearing time of the contact lens was 14 hours.

\section{RESULTS}

Of the initial 36 eyes fitted with RGP contact lenses, two patients were excluded from the study, one due to lack of motivation for wearing the lens, and one with an adverse reaction of the sutures. The results are summarized in Table 3-1.

Fifteen males and sixteen females comprised the remaining study group (34 eyes). The mean age of the patients at the initial contact lens fitting was 48.3 years ( \pm sd 18.2). Contact lens fitting started 6.9 months after operation $( \pm$ sd 1.79). All patients had the sutures in place at the time of contact lens fitting. All sutures remained in place throughout the first 9 months of the study (range $9-$ 24 months). Manifest subjective astigmatism at the initial contact lens fitting ranged from 1.0 to $12.0 \mathrm{D}$ (median: 4D). The mean follow-up time after initial contact lens fitting was 19.3 ( \pm sd 11.8) months, range, 6 to 27 months. Mean best spectacle corrected visual acuity before contact lens fitting was +0.358 ( \pm sd 0.183) LogMAR, and improved to $+0.106( \pm$ sd 0.111) LogMAR after contact lens fitting $(p<0.0001)$. Three eyes gained 5 lines of visual acuity, five eyes gained 4 lines, twelve eyes gained 3 lines, seven eyes gained 2 lines, five eyes one line and in two eyes we could not improve BSCVA. None of the 34 eyes developed rejection periods, infiltrates or progressive graft vascularisation.

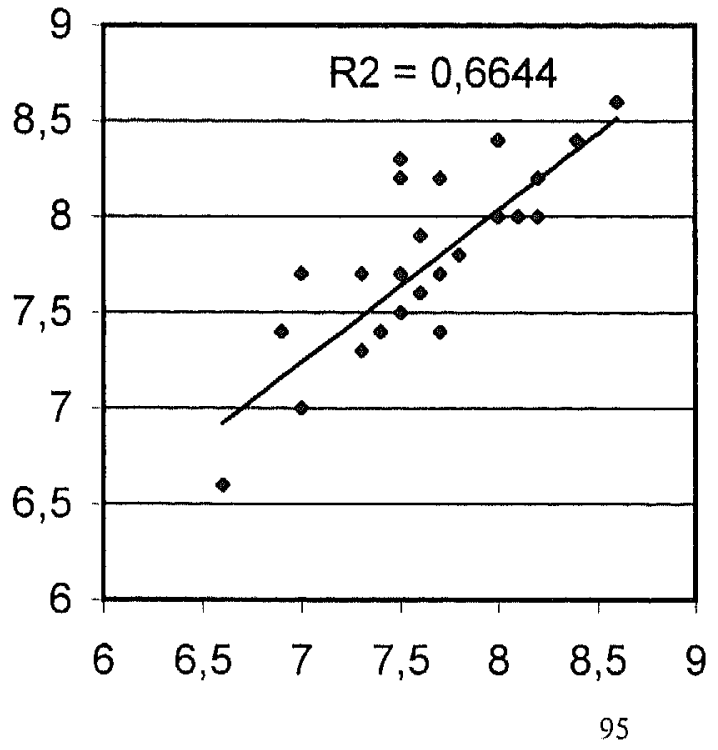

Figure 3-4

The $\mathrm{X}$ axis represents the corresponding radius at the inner side of the elevated wound edge.

The $Y$ axis represents the back optic zone radius of the dispensed contact lens. 
The back optic zone radius of all contact lenses used during the study ranged from $6.60-8.60 \mathrm{~mm}$ (median $7.70 \mathrm{~mm}$ ). There was a good correlation between the topographically based back optic zone radius and the back optic zone radius of the dispensed contact lens (Figure $3-4, R^{2}=0.667$ ). Twenty three of $36(64 \%)$ eyes were dispensed with a contact lens with a back optic zone radius identical to the corresponding radius of the inner side of the elevated wound edge, four eyes ( $11 \%$ ) were dispensed with a contact lens with a steeper BOZR, and nine eyes ( $25 \%$ ) with a flatter BOZR. The back optic zone diameter of the contact lenses used during the study ranged from $8.0-8.5 \mathrm{~mm}$ (median $8.4 \mathrm{~mm}$ ), and the contact lens overall diameter ranged from $10.2-12.3 \mathrm{~mm}$ (median $11.2 \mathrm{~mm}$ ).

All patients tolerated the contact lenses within the first four weeks after fitting and all completed the study. All grafts remained clear throughout the study period, and daily wearing time averaged $13.6 \pm \mathrm{sd} 4.7 \mathrm{hrs}$ (range 5 to 17 hours).

\section{DISCUSSION}

A review of the literature showed that earlier visual rehabilitation after penetrating keratoplasty with a contact lens has been reported in several other studies. Most studies report contact lens fitting after removal of the sutures. Wilson and coauthors (1992) removed the running sutures between 2 and 3 months after surgery and started fitting 4.1 months after surgery, using the contact lens as a mold to improve postoperative corneal topography. Gomes and coauthors (1996) started contact lens fitting 73 months after surgery, with the sutures in place. They used the topographic measurement $1.5-\mathrm{mm}$ superior to the visual axis to determine the back optic zone radius of the contact lens. Lopatinsky and coauthors (1993) reported the determining of the back optic zone radius by the same technique as Gomez but averaged the values from two separate computerized images for one eye. Sperber and coauthors (1995) also used the same fitting technique in 8 patients with the sutures in place. Koffler and coauthors (1994) report contact lens fitting in 9 patients with the sutures in place using the fluorescein pattern for selection of the final contact lens back optic zone radius.

Astigmatism and (or) anisometropia of more than $5 \mathrm{D}$ are common following penetrating keratoplasty and result in poor visual acuity after other wise successful penetrating keratoplasty surgery (Artaria 1995). We fitted contact lenses seven months after surgery, with the sutures in place, in patients with a low rejection risk profile (Table 3-2). When the sutures are out, we can fit contact lenses in all operated patients. 
Table 3-2.

Corneal Graft Rejection Risk Profile, during the first two years post-penetrating keratoplasty and contact lens fitting.

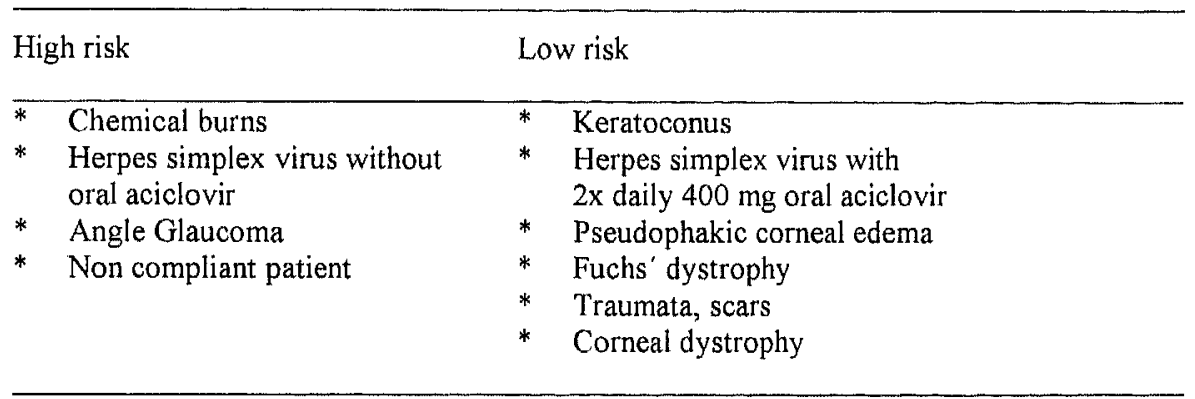

Selection of the back optic zone radius according to the central K-values and evaluation of the fluorescein pattern usually perform contact lens fitting in virgin corneas. In our experience, the use of routine methods for contact lens fitting after penetrating keratoplasty always resulted in a too steep fit, causing excessive peripheral impingement of the wound area. Slit lamp examination and videotopography showed that the edges of the circular transplant wound were 'elevated' relative to the adjacent central and peripheral corneal surfaces. We therefore hypothesized that the bearing of the contact lens may be improved if the dioptric values over the transplant wound were used for selection of the back optic zone radius, for two reasons.

First, the elevated wound ridge will always be in touch with the contact lens, irrespective of the selected back optic zone radius (Figure 3-1). Hence, the best possible contact lens bearing at the ridge may be expected to give a maximum of comfort in contact lens wearing. Second, the dioptric values at the inner side of the wound ridge may be true curvature values displayed on the videotopographic map, but the algorithm will probably smoothen out the dioptric values over the flat central- and the steep peripheral wound edge. The area peripheral to the wound is almost never displayed, because the irregular ring images in this area are discarded by the software. We therefore decided to choose the back optic zone radius of the first trial-lens according to the radius of the most regular ring segment, displayed over at least two clock hours at the inner side of the elevated wound ridge on the absolute tangential scale of the videotopographic map.

In virgin corneas, the central radius is used for selection of the contact lens back optic zone radius, so that the lens power equals the spectacle correction calculated back to the corneal plane. With our technique for lens 
fitting after penetrating keratoplasty, the back optic zone radius is chosen according to the radius on the transplant wound. Hence, the back optic zone radius may not have any correlation with the central radius of the transplanted cornea, i.e. the effective corneal power. As a result, the vault between the contact lens and the central cornea, i.e. the tear lens, as demonstrated by the fluorescein pattern, induces a large shift in refractive error.

Our fitting technique consists of using large lens diameters. Few studies have described large diameter contact lens fitting after penetrating keratoplasty. With the selection of the contact lens back optic zone radius over the elevated circular transplant wound, we achieved good centration with these large lens diameters and excellent stability on the cornea. Asymmetrical contact zones between cornea and contact lens will always lead to decentration of the contact lens. Centration of these large diameter lenses is facilitated by the natural difference in curvature between cornea and sclera. Movement and tear exchange is secured by sufficient flattening of the peripheral zone. Lopatynsky dispensed contact lens diameters of $8.5-9.6 \mathrm{~mm}$ (average $9.0 \mathrm{~mm}$ ) in penetrating keratoplasty patients. Manabe and coauthors (1986) used a diameter larger than the graft but did not mention the size. Genvert and coauthors (1985) fitted contact lens diameters ranged from 8.5 to $10.0 \mathrm{~mm}$ in penetrating keratoplasty patients. We used a mean contact lens diameter of $11.2 \mathrm{~mm}$ with a mean back optic zone diameter of $8.4 \mathrm{~mm}$.

The most comfortable lens fit was obtained when the lens had a slightly superior position and received support from the upper lid, with good movement and a relatively flat fluorescein pattern. During primary gaze, upward gaze and between blinks, the upper edge of the lens was retained under the upper lid. The bottom edge of the lens should be above the lower lid but with the edge of the optical zone below the inferior pupillary margin under primary gaze circumstances.

Compared to contact lens fitting in virgin corneas, the lens edge was elevated more than normal to increase the tear meniscus. This was acceptable because the upper lid already passed over the lens edge. This concept of lens performance, as if the contact lens was attached to the upper lid during blinking, may facilitate the tear-flow underneath the lens during blinking and eye movements. Tear film circulation with this large lens design is guaranteed and maintains adequate corneal metabolism.

Contact lens wear after penetrating keratoplasty has a potential risk factor of development of epithelial defects, corneal infiltrates, vascularisation, graft rejection or graft failure. Therefore close monitoring is needed especially during the first two years after operation when sutures are in place (Dart 1993). None of the patients developed infiltrates or infections, or had irreversible graft changes. Graft patients need to be educated to return promptly if they develop symptoms 


\section{Chapter 3}

of ocular pain, redness or decreased visual acuity, so potentially serious complications can be diagnosed early and treated appropriately,

Contact lens fitting in keratoplasty patients is challenging due to an abnormal corneal curvature especially in the area of the transplant wound. Rigid gas permeable contact lenses may be safe (Bourne \& Shearer 1995), and we recommend their use in selected patients for the management of postkeratoplasty astigmatism and anisometropia.

In summary the principals of our fitting technique are: 1. use an overall contact lens diameter of at least 11.0 millimeters to avoid lens instability and decentration; 2. use the elevated circular transplant wound as bearing zone and therefore use trial lenses with an back optic zone diameter of 8.5 millimeters; 3 . the lens must have a good clearance in the periphery; and 4. use a high Dk contact lens material. 


\section{RGP contact lens fitting technique after penetrating keratoplasty}

\section{REFERENCES}

Artaria LG.(1995): Computerisierte Hornhauttopographie in der Behandlung des hochgradigen Astigmatismus nach perforierender Keratoplastik. Klin Monatsbl Augenheilkd 206: 312-316

Beekhuis WH, van Rij G, Eggink FAGJ, Vreugdenhil W, Schoevaart CE.(1991): Contact lenses following keratoplasty. CLAO J 17: 27-29.

Binder PS, Kopecky L.(1992): Fitting the SofPerm contact lens after keratoplasty. CLAO J 18: 170-172.

Boderie VM, Touzeau O, Laroche L. (1999): Videokeratography, keratometry, and refraction after penetrating keratoplasty. J of Refractive Surg 15: 32-37.

Bourne WM, Shearer DR. (1995): Effects of long-term rigid contact lens wear on the endothelium of corneal transplants for keratoconus 10 years after penetrating keratoplasty. CLAO J 21: 265-267.

Dart JKG. (1993): Disease and risk associated with contact lenses. Br J Ophthalmol 77: 4953.

Eggink FAGJ,Vreugdenhil W, Beekhuis WH. (1994): Therapeutische kontaktlinsen nach perforierenden keratoplastiek. Die Kontaktlinse 28: 5-10

Genvert GI, Cohen EJ, Arentsen JJ, Laibson PR. (1985): Fitting gas-permeable contact lenses after penetrating keratoplasty. Am J of Ophthalmol 99: 511-514.

Gomes JAP, Rapuano CJ, Cohen EJ. (1996): Topographic stability and safety of contact lens use after penetrating keratoplasty. CLAO J 22: 64-69.

Ing JJ, Ing HH, Nelson LR, Hodge DO, Bourne WM. (1998): Ten-year postoperative results of penetrating keratoplasty. Ophthalmol 105: 1855-1865.

Karabatsas CH, Cook SD, Figueiredo FC, Diamond JP, Easty DL.(1998): Combined interrupted and continuos versus single continuous adjustable suturing in penetrating keratoplasty: a prospective randomized study of induced astigmatism during the first postoperative year. Ophthalmol 105: 1991-1998

Karabatsas CH, Cook SD, Sparrow JM. (1999): Proposed classification for topographic patterns seen after penetrating keratoplasty. Br J Ophthalmol 83; 403-409.

Koffler BH, Clements LD, Litteral GL, Smith VM. (1994): A new contact lens design for post-keratolasty patients. CLAO J 20: 170-175.

Lopatynsky M, Cohen EJ, Leavitt KG, Laibson PR. (1993): Corneal topography for rigid gas permeable lens fitting after penetrating keratoplasty. CLAO J 19: 41-44.

Manabe R, Matsuda M, Suda T. (1986): Photokeratoscopy in fitting contact lens after penetrating keratoplasty. Br J of Ophthalmol 70: 55-59.

McNeill JI, Aaen VJ (1999): Long-term results of single continuous suture adjustment to reduce penetrating keratoplasty astigmatism. Cornea 18: 19-24.

Shimazaki J, Tsubota K. (1997): Analysis of videokeratography after penetrating

keratoplasty: topographic characteristics and effects of removing running sutures. Ophthalmol 104: $2077-2084$

Solomon A, Siganos CS, Frucht-Pery J, (1999): Relaxing incision guided by videokeratography for astigmatism after keratoplasty for keratoconus. J of Refractive Surg 15 : 343-348.

Sperber LTD, Lopatynsky MO, Cohen EJ. (1995): Corneal topography in contact lens wearers following penetrating keratoplasty. CLAO J 21: 183-190.

Szczotka LB, Reinhart W. (1995): Computerized videokeratoscopy contact lens softwear for RGP fitting in a bilateral post keratoplasty patient: a clinical case report. CLAO J 21: 52-56. 


\section{Chapter 3}

Vreugdenhil W, Rijneveld WJ, Eggink FAGJ. (1994): Fitting therapeutic SoftPerm contact lenses in the event of corneal pathology with highly irregular astigmatism. $\mathrm{J}$ of the British Contact Lens ass 17: 59-61

Wilson SE, Friedman RS, Klyce SD. (1992): Contact lens manipulation of corneal topography after penetrating keratoplasty: a preliminary study. CLAO J 18: 177-182.

Yoshida K, Tazawa Y, Demong TT. (1999): Refractive results of post penetrating keratoplasty photorefractive keratectomy. Ophthalmic Surg and Lasers 30: 354-359. 


\section{A new technique for rigid gas permeable contact lens fitting following deep anterior lamellar keratoplasty}

Submitted for publication

Fred A.G.J. Eggink

Willem Vreugdenhil' ${ }^{1}$

Gerrit R.J. Melles M.D., Ph.D. ${ }^{2}$

1. The Rotterdam Eye Hospital, Rotterdam, The Netherlands

2. Netherlands Institute for Innovative Ocular Surgery, Rotterdam,

The Netherlands 


\section{Abstract}

Purpose: To evaluate a new technique for contact lens fitting following deep anterior lamellar keratoplasty.

Methods: For postoperative anisometropia or astigmatism, rigid gas permeable, tetra-curve contact lenses with a total diameter of $12.0 \mathrm{~mm}$, and a back optic zone diameter of $8.5 \mathrm{~mm}$, were fitted in 13 eyes of 13 patients, 3.9 months after surgery. The contact lens back optic zone radius was selected using the videotopographic K-values over the transplant wound. Visual outcome and contact lens performance were evaluated up to 2 years after surgery at intervals of 3 months.

Results: Mean best contact lens corrected visual acuity was $0.7( \pm 0.1)$. Mean contact lens daily wearing time averaged $11.8( \pm 3.1)$ hours. All grafts remained clear. One patient was excluded from the study due to noncompliance.

Conclusions: Quick visual rehabilitation after deep anterior lamellar keratoplasty may be achieved by fitting a large diameter rigid gas permeable contact lens. The back optic zone radius may be selected according to the videotopographic $\mathrm{K}$-value over the transplant wound. 


\section{Introduction}

Deep anterior lamellar keratoplasty may be performed as an alternative to penetrating keratoplasty. ${ }^{1-6}$ Although graft clarity is nearly always achieved, corneal surface irregularity and or astigmatism may decrease best spectacle corrected visual acuity. The visual performance may be improved by fitting a rigid gas permeable (RGP) or soft toric contact lens, a contact lens and spectacle combination, a piggyback system (a combination of soft and rigid contact lenses), or a hybrid lens. ${ }^{710}$ An RGP lens may be the most preferable, since this type of lens corrects high degrees of regular and irregular astigmatism and has high oxygen permeability.

The purpose of the study was to evaluate if a RGP contact lens could be fitted within the first months after deep anterior lamellar keratoplasty, and to determine the most effective method of choosing the back optic zone radius of the trial lens. (Figure $4-1$ ).

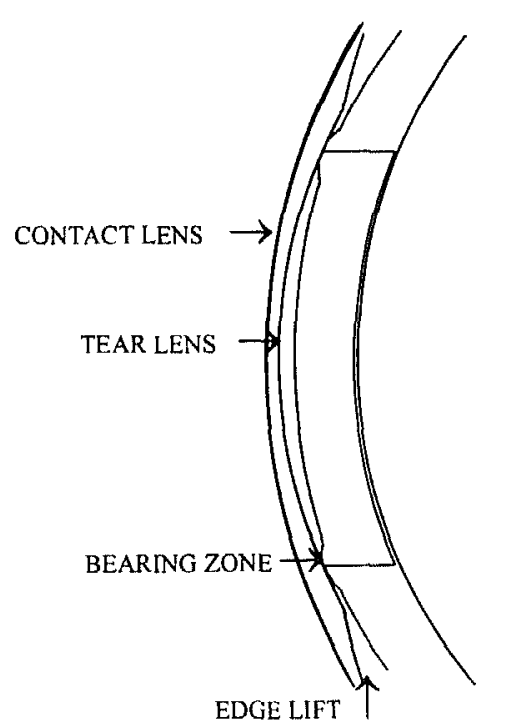

Figure 4-1.

In a cornea after deep anterior lamellar keratoplasty, the elevated transplant wound was used for contact lens bearing. Between the back surface of the contact lens and the operated cornea, the tear-film compartment neutralizes the corneal surface and replaces it optically with a new surface shaped by the concavity of the contact lens.

Figure 1. 


\section{Chapter 4}

\section{Material and Methods}

From a larger group of 50 patients, who underwent deep anterior lamellar keratoplasty, ${ }^{11}$ thirteen patients, 8 male and 5 female with a mean age of 43 ( \pm sd 13.6) years, were referred to the contact lens unit of our hospital for contact lens fitting, 3.9 ( \pm sd 1.3) months after surgery (Table). Seven patients had an astigmatism of 4 diopters or more, and six had an anisometropia of 4 diopters or more. Before-, and at three monthly intervals after surgery, contact lens performance was evaluated by measuring best spectacle- and contact lens corrected visual acuity, slit-lamp photography, keratometry and videotopography.

For selection of the back optic zone radius of the contact lens, the Kvalues over the circular transplant wound were used, as displayed on the tangential videotopographic color map (Alcon Eye Map, Alcon Laboratory inc. Software Version 5.50.03), i.e. the corneal radius at a regular ring segment over two clock hours at the inner side of the wound. If two or more regular ring segments were present, the segment with a radius nearest to $7.70 \mathrm{~mm}$ was chosen (the radius of the normal eye)

The tetra-curved trial set we used was designed by one of us (FE) and consisted of lenses with a back optic zone diameter of $8.5 \mathrm{~mm}$. The first peripheral curve was $0.5 \mathrm{~mm}$ flatter than the back optic zone radius and had a diameter of $10.5 \mathrm{~mm}$. The second peripheral curve was $1.5 \mathrm{~mm}$ flatter than the back optic zone radius and had a total diameter of $12.0 \mathrm{~mm}$. The edge radius was $12.5 \mathrm{~mm}$. All transitions were soft blended. In all cases we used a very high Dk contact lens material to avoid corneal edema such as Boston XO with a Dk of 100 (Polymer Technology Corp) or FluoroPerm 151 with a Dk of 151 (Paragon Vision Sciences). The lenses prescribed were custom made and can be manufactured by any contact lens laboratory. 
Contact lens fitting after lamellar keratoplasty

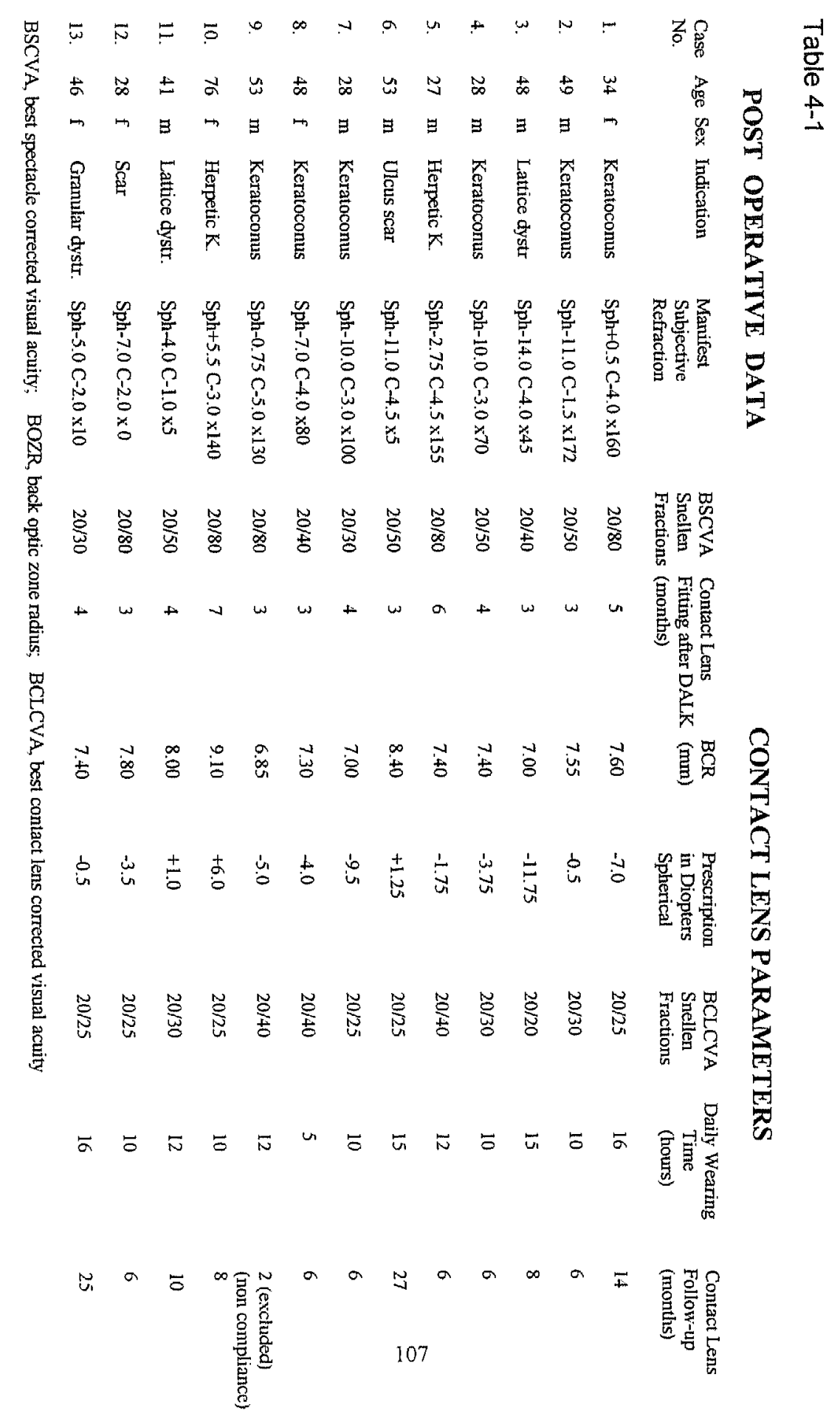




\section{Results}

At $3.9( \pm 1.3)$ months after deep anterior lamellar keratoplasty, a contact lens was fitted in 13 patient eyes. Eleven of $13(84 \%)$ eyes could be dispensed with a contact lens back optic zone radius selected according to the K-value over the inner side of the transplant wound on the videotopographic map. The back optic zone radius ranged from 7.0 to $9.1 \mathrm{~mm}$, the back optic zone diameter ranged from 8.2 to $8.5 \mathrm{~mm}$, and the total lens diameter from 11.0 to $12.0 \mathrm{~mm}$ (Table).

Mean follow-up after fitting was $10.6( \pm 7.2)$ months. Mean best contact lens corrected visual acuity was $0.7( \pm 0.1)$. None of the patients developed rejection periods or infiltrates. Anterior corneal vascularisation into the graft occurred in one patient, 10 months after lens fitting, due to a loose suture. After suture removal contact lens wear could be continued.

The large diameter contact lens was well tolerated by all patients. Daily wearing time averaged 11.8 ( \pm 3.3 ) hours, and all grafts remained clear throughout the study period. One patient discontinued the study after ten weeks, due to non-compliance.

\section{Discussion.}

Rigid contact lens fitting often improves the visual performance after penetrating keratoplasty. ${ }^{7.12}$ Most often, a contact lens is fitted at one year after surgery, after the removal of the sutures, and discontinuation of the steroid medication. Within the first year, soft contact lens fitting carries the risk of vascularisation along the suture tracts, requiring suture removal while wound healing is incomplete. Furthermore, rigid contact lens wear may interfere with selective suture removal, it may require frequent monitoring when the patient is using steroid medication.

After lamellar keratoplasty, the sutures may be removed at 4-6 months after surgery, and steroids can be tapered quicker, so that a contact lens may be fitted earlier. Since the corneal K-values often differ between the transplanted button and peripheral recipient rim, the aim of our study was to evaluate what type of contact lens is most suitable in these eyes, and what fitting technique is most effective.

In the current study, a large diameter, rigid gas permeable contact lens fitting technique is described, by which a mean visual acuity of $0.7( \pm 0.1)$ was achieved, and an average wearing time of approximately 11 hours per day. Few studies have described large diameter contact lens fitting after penetrating keratoplasty. ${ }^{7,12}$ In our study, we used a contact lens diameter of 11.0 to 12.0 
$\mathrm{mm}$, with an optical zone of 8.2 to $8.5 \mathrm{~mm}$. The advantage of a large contact lens diameter after keratoplasty ${ }^{13}$ and other types of corneal surgery, ${ }^{14,15}$ may be that lens centration and stability are excellent, because of the difference in curvature between comea and sclera. The most comfortable lens fit was obtained when the lens showed a slightly upward position while receiving support from the upper lid, good movement and a relatively flat fluorescein pattern. During primary gaze, upward gaze and between blinks, the upper edge of the lens was retained under the upper lid. The bottom edge of the lens should be above the lower lid, but the edge of the optical zone below the inferior pupillary margin.

Compared to contact lens fitting in virgin corneas, the lens edge was elevated more than normal to increase the tear meniscus. This was acceptable because the upper lid does not have to pass over the lens edge. This concept of lens performance, as if the corneal lens was attached to the upper lid during blinking, may facilitate the tear-flow underneath the lens during blinking and eye movements.

After keratoplasty, the central K-values may not be representative for the entire corneal surface area, as in virgin corneas. The radius of the central optical zone over the transplanted button may show no correlation with the radii of the peripheral recipient cornea. In our experience, routine fitting methods after deep anterior lamellar keratoplasty always resulted in a too steep fit, causing peripheral impingement of the wound area. Slit lamp examination and videotopography suggested that the circular transplant wound was 'elevated' relative to the adjacent central and peripheral corneal surfaces. We therefore hypothesized that contact lens bearing may be improved if the $\mathrm{K}$-values over the transplant wound were used for selection of the back optic zone radius, because the wound ridge will always touch the contact lens, irrespective of the selected base curve. Hence, the best possible contact lens bearing at the ridge may be expected to give a maximum of comfort in contact lens wearing. 


\section{Chapter 4}

\section{References.}

1. Melles GR, Lander F, Rietveld FJ, Remeijer L, Beekhuis WH, Binder PS. A new surgical technique for deep stromal, anterior lamellar keratoplasty. Br.J Ophthalmol 1999;83:32733.

2. Melles GRJ, Remeijer L, Geerards AJM, Beekhuis WH: The future of lamellar keratoplasty. Curr Opin Ophthalmol 1999;10:253-9.

3. Krumeich $\mathrm{JH}$, Daniel J, Winter M. Tiefe lamelläre keratoplastik mit dem geführten trepan system zur übertragung von spenderscheiben in ganzer dicke. Ophthalmologe 1998; 95:748-54

4. Panda A, Singh Bageshwar LM, Ray M, Singh JP, Kumar A. Deep lamellar keratoplasty versus penetrating keratoplasty for corneal lesions. Cornea 1999;18:172-5.

5. Amayem AF, Anwar M. Fluid lamellar keratoplasty in keratoconus. Ophthalmology 2000; 107:76-9.

6. Manche EE, Holland GN, Maloney RK. Deep lamellar keratoplasty using viscoelastic dissection. Arch of Ophthalmol 1999;117:1561-5

7. Beekhuis WH, van Rij G, Eggink FAGJ, Vreugdenhil W, Schoevaart CE. Contact lenses following keratoplasty. CLAOJ 1991;17:27-9.

8. Vreugdenhil W, Rijneveld WJ, Eggink FAGJ. Fitting therapeutic SoftPerm contact lenses in the event of corneal pathology with highly irregular astigmatism. $J \mathrm{Br}$ Contact Lens Ass 1994;17:59-61.

9. Lopatynsky M, Cohen EJ, Leavitt KG, Laibson PR. Corneal topography for rigid gas permeable lens fitting after penetrating keratoplasty. CLAO J 1993;19:41-4

10. Binder PS, Kopecky L. Fitting the SoftPerm contact lens after keratoplasty. CLAO J 1992;18:170-2.

11. Nieuwendaal C, Lander F, Melles GRJ: Clinical results of deep, anterior lamellar keratoplasty following manual dissection through a scleral tunnel incision. Submitted.

12. Eggink FAGJ, Nuijts RMMA. A new technique for rigid gas permeable contact lens fitting following penetrating keratoplasty. Acta Ophthalmol Scand 2001;79:245-50

13. Eggink FAGJ, Vreugdenhil W, Beekhuis WH. Therapeutische kontaktlinsen nach perforierenden keratoplastiek. Die Kontaktlinse 1994;28:5-10,

14. Eggink FAGJ, Beekhuis WH. Contact lens fitting following radial keratotomy and other relaxing incisions. Contactlogia 1989;11:164-8.

15. Eggink FAGJ, Beekhuis WH, Nuijts RMMA. Rigid gas permeable contact lens fitting in LASIK patients for the correction of multifocal corneas. Graefe's Archive for Clin Experimental Ophthal 2001;361-6. 


\section{Granular Dystrophy of the Cornea, Contact Lens Fitting After Phototherapeutic Keratectomy}

Fred A.G.J. Eggink and W. Houdijn Beekhuis

The Eye Hospital, Rotterdam, The Netherlands CORNEA 14(2): 217-222, 1995.

Supported in part by a grant of The Eye Hospital Rotterdam Research Foudation. 


\section{ABSTRACT.}

We performed a phototherapeutic keratectomy using excimer laser 193-nm ablation in a patient with granular dystrophy of the cornea. The hyperopic shift caused by the 5-mm diameter tissue ablation could effectively be corrected by a high oxygen-transmissible, aspheric, rigid contact lenses 1 week after treatment. Corneal topographic analysis was used to monitor the changes in corneal shape after excimer treatment. The 3.5-D hyperopic shift did not change after 4 months, but corneal shape altered during this period. It was not necessary to adjust lens parameters. The central corneal area was clear, and visual acuity improved from $20 / 40$ to $20 / 20$. 


\section{INTRODUCTION.}

Granular dystrophy (Groenouw I dystrophy, bread-crumb dystrophy) was first described by Groenouw in $1890^{(1)}$. Its hereditary pattern is autosomal dominant ${ }^{(2.3)}$. White opacities appear in the superficial stroma layers in the central part of the cornea during the second decade of life ${ }^{(4)}$. The disease is bilateral and symmetrical, and the peripheral cornea remains free of lesions ${ }^{(5)}$. There are several variants of the usual course. Although the epithelium is rarely affected, the basement membrane of the epithelium may be irregular in thickness or absent in some areas ${ }^{(6)}$, and Bowman's membrane may be thinner than usual or absent. The hemidesmosomes are rarely affected. The substance that accumulates in the superficial stromal lesions in granular dystrophy is hyaline-a, noncollaginine and sulfur-containing amino acids ${ }^{(7.8)}$. There are also phospholipids in the stromal lesions. When there is a decrease of visual acuity, lamellar and penetrating keratoplasties have been the most common methods of treating this dystrophy, but recurrence of the disorder in the graft is possible ${ }^{(9,10)}$. Preliminary reports of the past 3 years have demonstrated the capability of the 193-nm excimer laser to ablate corneal opacities via phototherapeutic keratectomy (PTK) ${ }^{(11-13)}$. We treated one patient with granular dystrophy with PTK and fitted the patient for rigid gas-permeable contact lenses 1 week after treatment. The PTK and the fitting procedure of the contact lenses is described.

\section{MATERIALS AND METHODS.}

\section{Preoperative Examination}

A 17-year-old girl was diagnosed with granular dystrophy in 1991. The family history was positive; her younger sister had been diagnosed with the same dystrophy. Her visual acuity had deteriorated during the preceding year from $20 / 30$ in both eyes to 20/35 with Spherical (Sph) +3.00 Cylinder (Cyl) -3.50 axis 30 in the right eye and 20/40 with $\mathrm{Sph}+2.25 \mathrm{Cyl}-0.75$ axis 150 in the left eye. She complained about loss of vision and severe photophobia. She had never worn contact lenses. Phototherapeutic keratectomy was planned, first on the left eye and 4 months later on the right eye.

Informed consent was obtained from the patient. Before treatment, a complete ophthalmologic examination was performed, including slit-lamp photography, corneal topography (Topographic Modeling System TMS 1, Computed Anatomy, New York, NY, U.S.A.) (Figs. 5.2 and 5.3), and ultrasonic 
pachometry (Villaseñor Ultrasonic Pachymeter, Alcon Laboratories, Inc., Fort Worth, TX, U.S.A.). The patient was contact lens intolerant because the corneal surface was too irregular; for this reason, her best-corrected visual acuity with contact lenses was unknown to us

\section{Procedure}

We used the 193-nm argon fluor excimer laser (Summit Technology, Watertown, MA, U.S.A.). Topical anesthesia with oxybuprocain and tetracain was administered before treatment in combination with pilocarpine and clonidine eyedrops. To control postoperative pain after excimer ablation, we instilled three drops of nonsteroidal anti-inflammatory drug (sodium) diclofenac before treatment. During treatment the patient was supine, and the eye was held open by an eyelid speculum. The patient was fixating on a green light projected in the center of the laser aperture. The diaphragm was fixed on the maximum beam diameter of $5.0 \mathrm{~mm}$. The laser delivers a series of pulses at each setting, according to the preoperative specifications entered into the computer.

Removal of the epithelium in this case of PTK is not advisable because the epithelium acts as a modulator, smoothing the underlying basement membrane and superficial stromal irregularities. With each pulse the excimer ablates 0.25 $\mu \mathrm{m}$ of the cornea. With the first 300 pulses we ablated the central part of the corneal epithelium and $\sim 25 \mu \mathrm{m}$ of underlying stroma.

During the actual ablation, the cornea is kept dry and becomes transiently opaque after receiving the initial laser pulses. The intraoperative evaluation of the amount of residual opaque stroma tissue is important and requires temporary cessation of the laser ablation and slit-lamp examination after a number of pulses. We accompanied the patient to a slitlamp after the delivery of 300 pulses and repositioned her under the laser to administer additional laser pulses. To create a smooth edge of the ablated zone, we used small amounts of smoothing agents (various concentrations of methylcellulose eye drops) and moved the head of the patient in a circular manner under the 5-mm diameter laser beam. This technique is known as "smoothing." It is not possible to accurately predict depth of ablation using this technique. We needed 370 pulses for the right eye and 543 for the left eye before the central part of the granular opacities were ablated. Many pulses are used to evaporate the smoothing agent and do not contribute to corneal tissue ablation. Immediately after treatment, we performed ultrasonic pachometry to evaluate the amount of ablated tissue which was in the right eye 105 and in the left $99 \mu \mathrm{m}$. After ablation, tetracycline eye ointment was instilled and the operated eye was patched overnight. The patient received tetracycline eye ointment three times a day for the first week. 


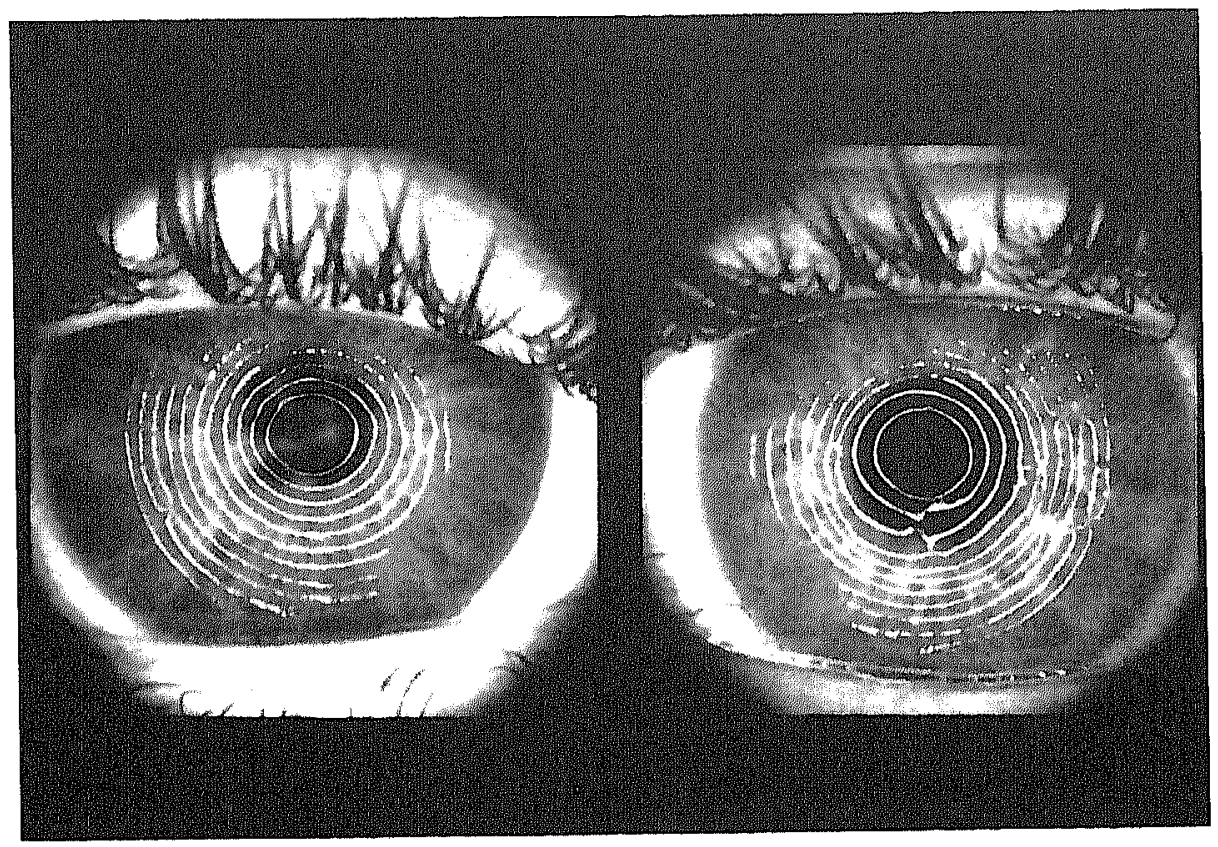

Fig 5-I. Photokeratoscope image of the right (left) and left (right) eyes before treatment.

Any removal of anterior corneal tissue will change the refracting surface of the cornea and flatten it, causing a hyperopic shift.

\section{Contact Lens Fitting}

At 1 week, we saw a clear central cornea with intact epithelium. The visual acuity of the right eye with an additional correction of $\mathrm{Sph}+6.50 \mathrm{Cyl}-3.50$ axis 180 was $20 / 40$ and of the left eye with Sph +6.75 Cyl -2.75 axis 170 was $20 / 60$. Corneal topographic mapping was repeated (Figs. 5-2 and 5-3). The treated 
central zone showed considerable irregular astigmatism. The peripheral cornea curvature $2.8 \mathrm{~mm}$. out of the topographic center in her right eye was $\sim 8.20 \mathrm{~mm}$ and in her left eye was $8.00 \mathrm{~mm}$, which was approximately equal to the preoperative value. We used this pericentral zone of the comea as the bearing zone. The initial trial lens we selected had a back optic zone radius of $8.20 \mathrm{~mm}$ for the right eye and $8.00 \mathrm{~mm}$. for the left.

The diameter of the contact lens was chosen so that the upper edge of the lens would ride under the upper lid to facilitate lens movement, enhance tear exchange, and increase comfort. The lens diameter we ordered was $10.2 \mathrm{~mm}$.

Corneal topographic mapping and fluorescein evaluation determined the eccentricity of the back optic zone radius and the peripheral edge lift, as listed in Table 1 and described elsewhere ${ }^{(14,15)}$. Based on earlier observations, our protocol called for intensive topical corticosteroid used five times a day during the first 2 months, three times a day during the third month, and once a day during the fourth month after surgery. Fluorometholone was chosen for its potency as a surface-active agent and diminished risk of increasing the intraocular pressure ${ }^{(16)}$. During the dispensing visit, the patient was instructed in lens handling and Allergan $^{\text {(i) }}$ contact lens care solutions were dispensed. Follow-up examinations were performed at 2, 4, and 8 weeks, and at 4 months after treatment. At each follow-up visit, visual acuity was determined and subjective refraction with the lens in place was performed. Slit-lamp examination was performed with and without fluorescein. The lens was removed and another slit-lamp evaluation was performed. Subjective refraction, corneal topographic analysis, and pachometry were also performed.

\section{RESULTS.}

The visual acuity achieved with the contact lens during the study was compared with that obtained with spectacles (Table 5-2). Regression after the initial flattening of the cornea curvature is seen in all excimer laser patients due to epithelial thickening at the edge of the ablated zone during the first months after surgery. A change in refraction caused by a change in corneal curvature does not affect visual acuity with the contact lens. Because of the fillingup characteristics of the tear film, only the tear lens beneath the contact lens will change in shape. Lens movement is possibly changed with a change of curvature of the central part of the cornea, but we based our lens alignment on the mid-peripheral part of the cornea. Lens binding was prevented by choosing a flat base curve and progressive eccentricity to the periphery of the lens (Table 5.1). 
A comparison of the topographic maps of this patient 1-week and 4 months after PTK, demonstrated a change in the surface profile in the same meridia, suggesting that epithelial hyperplasia or possible new collagen production in the stroma had modified the refractive power of the cornea.

After 4 months we saw a complete quiet cornea with a trace of haze and no recurrence of the disorder. Contact lenses were tolerated well.

Table 5-1.

Contact lens specifications

\begin{tabular}{lll}
\hline & Right eye & Left eye \\
\hline Material $^{\text {" }}$ & Boston Equalens 11 \\
Dk gas to gas method" $^{\mathrm{a}}$ & $130\left(\times 10-11\left(\mathrm{~cm}^{2} / \mathrm{s}\right)(\mathrm{Ml} / 02 \times \mathrm{mm} \mathrm{Hg})\right.$ at $35^{\circ} \mathrm{C}$ \\
Refractive index $^{\mathrm{a}}$ & 1.422 & 800 \\
Base curve (mm) $_{\text {Prescription (spherical) }}$ & 820 & +4.75 \\
Diameter (mm) & +6.25 & 10.2 \\
Front optical zone diameter (mm) & 10.8 & 8.5 \\
Peripheral edge lift & 8.5 & 0.102 \\
Eccentricity" & 0.102 &
\end{tabular}

"Data apply to both eyes.

Table 5-2. Data before and after treatment

\begin{tabular}{lllll}
\hline & Before treatment & $1 \mathrm{wk}$ & $1 \mathrm{mos}$ & $4 \mathrm{mos}$ \\
\hline Right eye VA & $20 / 35$ & $20 / 40$ & $20 / 25$ & $20 / 25$ \\
Subjective refraction & $+3.00-3.50$ & $+6.50-3.50$ & $+5.5-3.25$ & $+6.5-1.25$ \\
VA with lens & - & $20 / 20$ & $20 / 20$ & $20 / 20$ \\
Average corneal radius & $7.34 \mathrm{~mm}$ & 8.19 & 8.14 & 8.22 \\
Pachometry $(\mu \mathrm{m})$ & 486 & 426 & 432 & 416 \\
Corneal haze & - & none & none & none \\
& & & & \\
Left eye VA & $20 / 40$ & $20 / 60$ & $20 / 40$ & $20 / 25$ \\
Subjective refraction & $+2.25 \times \mathrm{C}-0.75$ & $+6.75-2.75$ & $+5.0-1.25$ & $+5.0-1.25$ \\
VA with lens & - & $20 / 20$ & $20 / 20$ & $20 / 20$ \\
Average corneal radius & $7.28 \mathrm{~mm}$ & 8.19 & 8.01 & 8.05 \\
Pachometry $(\mu \mathrm{m})$ & 478 & 412 & 430 & 424 \\
Corneal haze & - & none & trace & trace \\
& & & & \\
\hline
\end{tabular}




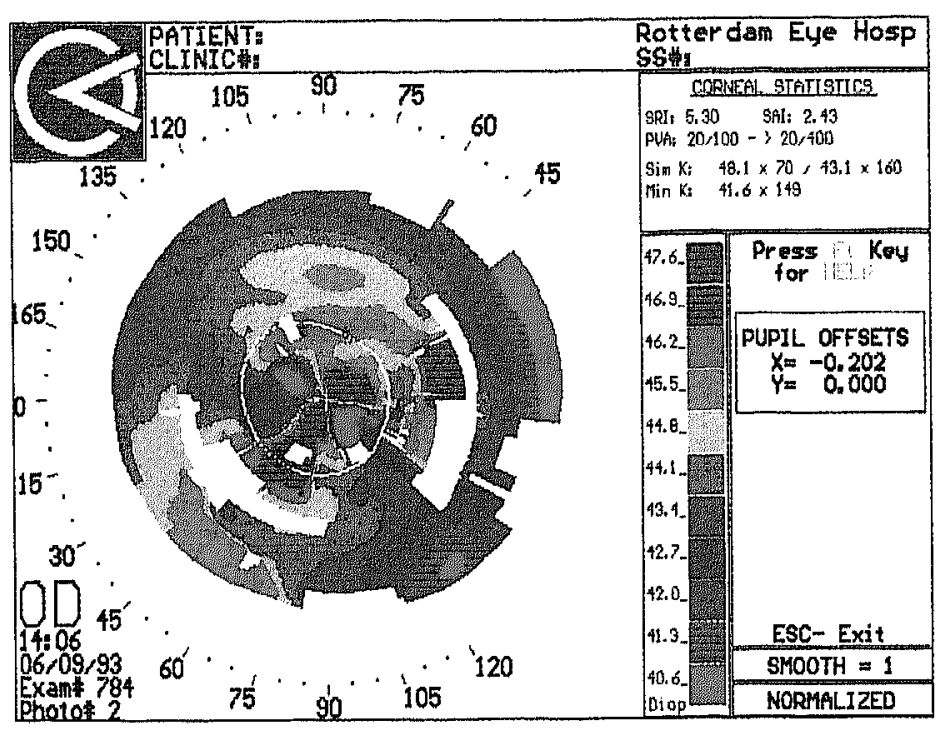

Fig. 5-2 a: Cornea topography of the right eye 1 week after treatment.

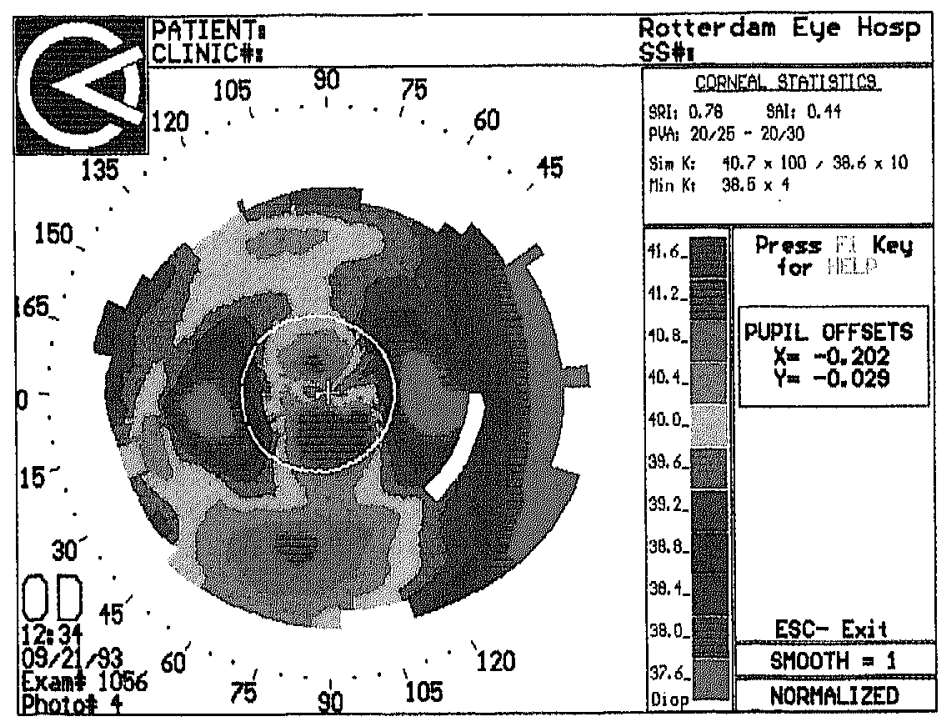

Fig. 5.2. b: Cornea topography of the right eye 3 months after treatment 


\section{DISCUSSION.}

New procedures should show clinically significant advantages over our present practice before they are accepted as standard procedure. The 193-nm excimer laser offers a potentially beneficial therapeutic technique for the precise removal of anterior corneal tissue for the treatment of superficial corneal opacifications, such as granular dystrophy's.

The astigmatism, temporary irregularity of the cornea, and hyperopic shift after PTK makes it nearly impossible to use commonly applied contact lens fitting techniques using the central keratometric readings.

Fitting contact lenses 1 week after PTK surgery was questioned by McCartney et al. ${ }^{(17)}$. They found in rabbits that it was not until 10 days post wounding that epithelial thickness and hemidesmosome number had returned to preoperative values and that adenosine triphosphate levels had returned to $90-95 \%$ of the control values.

The peripheral bearing zone of the contact lens on the astigmatic comea allows an uninterrupted tear flow under the lens during blinking. After PTK, the epithelium will slowly smooth irregularities in the keratectomy area ${ }^{(18)}$. Wu et al. found that the reepithelialization took place with variable thickening and in some areas the basal layer projected into the superficial stroma, attempting to fill in minute stromal defects ${ }^{(19)}$.

The long-term effectiveness of excimer laser treatment of patients with granular dystrophies is unknown, but recurrences of the disorder must be included. In case of a recurrence of the granular dystrophy, another excimer laser treatment is debatable because thinning of the cornea with another $70 \mu \mathrm{m}$ (for the right eye) should give a reduction of $28 \%$ of initial corneal thickness. However, the excimer treatment is much less invasive than a lamellar or penetrating graft.

Longer follow-up may demonstrate the permanent character of the treatment and effectiveness of PTK in patients with granular dystrophy as an alternative to conventional keratoplasty. 


\section{REFERENCES.}

1. Groenouw A. Knötchenförmige Homhauttrübungen (Nodulicorneae). Arch Augenheilkd $1890 ; 21: 281-89$.

2. Duke-Elder S, Leigh AG. Diseases of the outer eye. Cornea and sclera. In: Duke-Elder S, ed. System of ophthalmology. Vol. VIII, part 2. St. Louis, MO: CV Mosby, 1965:927-33.

3. Rodrigues MM, Gaster RN, Pratt MV. Unusual superficial confluent form of granular corneal dystrophy. Ophthalmology 1983;90:1507-11.

4. Pinckers A, Otto AJ, van den Heuvel JEA. A family pedigree with corneal dystrophy, tapetoretinal degeneration and albinism. Acta Ophthalmol 1973;51:445-60.

5. Smolin G, Thoft RA. The cornea. Boston: Little, Brown, 1990:438-9.

6. Johnson BL, Brown SI, Zaidman GW. A light and electron microscopic study of recurrent granular dystrophy of the cornea. Am J Ophthalmol 1981;92:49-58.

7. Garner A. Histochemistry of granular dystrophy. Br J Ophthalmol 1969;53:799-807.

8. Akiya S, Brown SI. Granular dystrophy of the cornea. Arch Ophthalmol 1970;84:179-92.

9. Tripathi RC, Garner A. Corneal granular dystrophy. A light and electron microscopical study of its recurrence in a graft. Br J Ophthalmol 1970;54:361-72.

10. Stuard JC, Mund ML, Iwamoto T, Troutman RC, White H, DeVoe AG. Recurrent granular corneal dystrophy. Am J Ophthalmol 1975;79:18-24.

11. Sher NA, Bowers RA, Zabel RW, et al. Clinical use of the 193-nm excimer laser in the treatment of corneal scars. Arch Ophthalmol 1991;109:491-8.

12. Fagerholm $P$, Fitzsimmons $T$. Tengroth B, Öndahl M. Excimer laser photoablation of corneal opacities and irregularities. ARVO 1991;(suppl):720.

13. Gartry D, Muir MK, Marshall J. Excimer laser treatment of corneal surface pathology: a laboratorium and clinical study. Br J Ophthalmol 1991;75:258-69

14. Eggink FAGJ, Beekhuis WH. Contact lens fitting following radial keratotomy and other relaxing incisions. Contactologia 1989; 11: 164-8

15. Beekhuis WH, van Rij G, Eggink FAGJ, Vreugdenhil W, Schoevaart CE. Contact lenses following keratoplasty. CLAO J 1991;17:27-9.

16. Steward R, Kimbrough R. Intraocular pressure response to topical fluoromethalone. Arch Ophthalmol 1979;97:2139-40.

17. McCartney MD, Thomas DM, Mahendroo PP. An electron microscopic and nuclear magnetic resonance spectroscopic evaluation of rabbit corneal epithelial wound healing. Invest Ophthalmol Vis Sci 1992;33:2917-25.

18. Taylor DM, I'Esperance FA, Warner JW, et al. Experimental corneal studies with the excirner laser. J Cataract Refract Surg 1989;15:384-9.

19. Wu WCS, Stark WJ, Green WR. Corneal wound healing after 193-run excimer laser keratectomy. Arch Ophthalmol 1991;109:1426-32. 


\title{
Recovery of the visual acuity in a family with Reis-Bückler dystrophy.
}

\author{
Fred A.G.J. Eggink \\ Annette J.M. Geerards MD \\ W. Houdijn Beekhuis MD
}

The Eye Hospital, Rotterdam, The Netherlands 


\section{ABSTRACT}

Introduction: The hereditary Reis-Bückler dystrophy is one of the anterior localized corneal dystrophies with superficial reticulated opacities, sometimes in combination with recurrent attacks of corneal erosion. Phototherapeutic Keratectomy (PTK) is now the first method to consider for managing this disease when intervention is required.

Methods: We performed a phototherapeutic keratectomy using excimer laser 193-nm ablation in six eyes of four patients belonging to the same family with a Reis-Bückler dystrophy from which two eyes had a recurrence of the Reis-Bückler dystrophy in the lamellar keratoplasty and one in the penetrating keratoplasty of the cornea. We determined the refractive change, the best spectacle visual acuity and the best contact lens corrected visual acuity, six months following surgery. In one case we had to fit a rigid contact lens to correct the hyperopic shift which caused anisometropia.

Results: The mean spherical refractive change six months after PTK surgery was $+0.33 \pm s d 1.8 \mathrm{D}$. A hyperopic shift was observed in four eyes. Visual acuity remained stable six months to two years after surgery. The central corneal area remained clear, and mean best spectacle corrected visual acuity improved from +0.8 LogMAR before PTK to +0.15 LogMAR six months after. Mean six months best spectacle corrected visual acuity ( +0.15 LogMAR \pm sd 0.16$)$ did not significantly differ from best contact lens corrected visual acuity $(+0.125$ LogMAR \pm sd 0.23$)$. After fitting a contact lens in one patient to correct anisometropia, the hyperopic shift did not change significantly during 12 months of follow-up. It was not necessary to adjust the contact lens parameters during the study.

Conclusion: PTK corneal surgery is the treatment of first choice when intervention is required in patients with Reis-Bückler dystrophy. Six months after treatment best spectacle corrected visual acuity could not been improved with rigid contact lenses. 


\section{INTRODUCTION}

The clinical manifestation of corneal dystrophies depends on the layer of the cornea that is affected [22]. Anterior membrane dystrophies are characteristically symptomatic, with painful recurrent corneal erosions, which are results from abnormalities of the epithelium, the corneal basement membrane, or Bowmans' layer [9]. The Reis-Bückler hereditary pattern is autosomal dominant $[3,24]$. Confocal microscopy helps in diagnosing the clinical suspicion of the disorder [25]. Molecular biologic investigation has shown that Reis-Bïckler, granular, and lattice type-I dystrophies share the same genetic locus on chromosome 5q31 [16, 17]. Bückler first described Reis-Bückler dystrophy in 1949 [2], from which two patients were seen by Reis in 1917 [18]. Fine graywhite opacities appear in the subepithelial region extending almost to the limbus, replacing Bowmans' layer with a diffuse frosted deposits in the anterior stroma layers. The Bowmans' layer is generally absent and replaced by highly reflective, irregular material. The superficial epithelium is normally not effected [9]. The surface irregularities in the central part of the comea, beginning in the first decade of life, may give severe recurrent ocular irritation affecting the visual acuity during the second decade of life [20]. The disease is bilateral and symmetrical, and the peripheral cornea near the limbus remains free of lesions. The collagen replacing Bowmans' membrane is eosinophilic and the interrupted granular material separating the layers of collagen is even more eosinophilic. The epithelial basement membrane is present in some areas but absent in others. The hemidesmosomes are usually missing from the cell membrane in areas where the basement membrane is absent [11]. The portions of Bowmans' membrane that are preserved slow the normal arrangement of 200 to $300 \AA$ thick collagen fibrils. The connective tissue that replaces Bowmans' layer is mostly collagen with a diameter of 300 to $400 \AA$ showing localized areas of increased density [23].

When there is a decrease of visual acuity, lamellar and penetrating keratoplasties have been the most common methods of treating this dystrophy, but recurrence of the disorder in the graft is possible [8]. Preliminary reports of the past 5 years have demonstrated the capability of the 193-nm excimer laser to ablate corneal opacities via phototherapeutic keratectomy (PTK) $[5,6]$. We treated four patients from the same family with PTK, three of them had a recurrence of Reis-Bückler dystrophy in the graft. In one patient we had to fit a rigid gas-penneable contact lens for the correction of anisometropia, caused by the hyperopic shift. The results of the PTK treatments and the contact lens fitting procedure are described. 


\section{MATERIAL AND METHODS}

\section{Preoperative Examination.}

Informed consent was obtained from all patients. Preoperative and follow up visits included a detailed ophthalmologic examination: anterior segment photography, corneal topography (Alcon Eye Map, Alcon Laboratory inc. Software Version 5.50), ultrasonic pachymetry (Pach-pen XL; Mentor O\&O Norwell), subjective refraction and central keratometry (Topcon KR 3500 auto kerato-refractometer, Topcon Corporation). Visual acuity was measured using a high contrast Vector Vision LogMAR chart (Dayton, Ohio, USA).

\section{PTK Procedure}

We used the 193-nm argon fluor excimer laser from Bausch \& Lomb, Technolas 116 version $2.2 \mathrm{c}$ in all patients (Bausch \& Lomb Inc., Rochester). Topical anesthesia with oxybuprocain was administered before treatment. Treatments were done by the two surgeons (WB, AG). To control postoperative pain after excimer ablation, we instilled three drops of nonsteroidal antiinflammatory drug (sodium) diclofenac before treatment. During treatment the patient was supine, and the eye was held open by an eyelid speculum. The patient was fixating on a red light projected in the center of the laser aperture. The diaphragm was fixed on the maximum beam diameter of $7.0 \mathrm{~mm}$. The laser delivers a series of pulses at each setting, according to the preoperative specifications entered into the computer.

Manual removal of the epithelium in these cases of PTK is not advisable because the epithelium acts as a modulator, smoothing the underlying superficial irregularities. With each laser pulse the theoretical ablation depth is $0.25 \mu \mathrm{m}$. With the first 300 pulses we ablated the central part of the corneal epithelium and $-25 \mu \mathrm{m}$ of underlying stroma.

During the actual ablation, the comea is kept dry and becomes transiently opaque after receiving the initial laser pulses. The intraoperative evaluation of the amount of residual opaque stroma tissue is important and requires temporary cessation of the laser ablation and slit-lamp examination after a number of pulses. We accompanied the patient to a slitlamp after the delivery of the first 300 pulses and repositioned the patient under the laser to administer additional laser pulses. To create a smooth edge of the ablated zone, the laser used a wobbling mirror technique. We did not use smoothing agents during ablation [12]. The pulses we 
needed to ablate the central part of the Reis-Buickler opacities are listed in the Table 6-1.

Postoperative management.

Postoperative care was directed toward facilitating reepithelialization, minimizing inflammation and scarring, and avoiding infection. In general, the operated eye was patched overnight with topical Polymyxine B drops. Polymyxine B drops were continued three times a day until epithelialization was completed. Mean visual acuity was calculated using the standard LogMAR chart.

\section{CASE 1.}

A 37 -year-old male was referred to us in 1985,22 years old, diagnosed with Reis-Bückler dystrophy since 1982. The family history was positive (Figure 6-1). A lamellar transplant was performed in 1985 for the left eye and in 1988 for the right eye. The diagnosis was supported by reports of pathologic findings. In 1996 a recurrence of the Reis-Buickler dystrophy developed in the lamellar transplant of the left eye. His visual acuity had deteriorated during the preceding years from 0.0 LogMAR (1.0 in Snellen) in both eyes to +0.3 LogMAR (0.5) with Spherical $(\mathrm{Sph})+3.25$ Cylinder $(\mathrm{Cyl})-4.00$ axis $160^{\circ}$ in the right eye and +0.8 LogMAR (0.15) with $\mathrm{Sph}+2.25 \mathrm{Cyl}-1.75$ axis $20^{\circ}$ in the left eye. He complained about loss of vision and severe photophobia. He had no contact lens history. The corneal surface of the left eye was too irregular to fit a rigid gas permeable contact lens; for this reason, his best contact lens corrected visual acuity was unknown to us. Phototherapeutic keratectomy was planned on the left eye. Before PTK the corneal thickness was $750 \mu \mathrm{m}$.

\section{Contact Lens Fitting Technique.}

At 1 week following PTK, we saw a clear central cornea with intact epithelium. The visual acuity six months after treatment of the left eye with an additional correction of Sph $+2.00 \mathrm{Cyl}-1.25 \times 15^{\circ}$ was $0.0 \operatorname{LogMAR}(1.0)$. One year after treatment the correction of the left eye with an addition of Sph +5.00 Cyl $-2.75 \times 18^{\circ}$ was -0.1 LogMAR (1.25). Corneal topographic mapping was repeated. The patient complained about anisometropia, due to the hyperopic shift. We decided to fit an RGP contact lens for the left eye. 
Chapter 6

$\Xi \quad=\quad-$

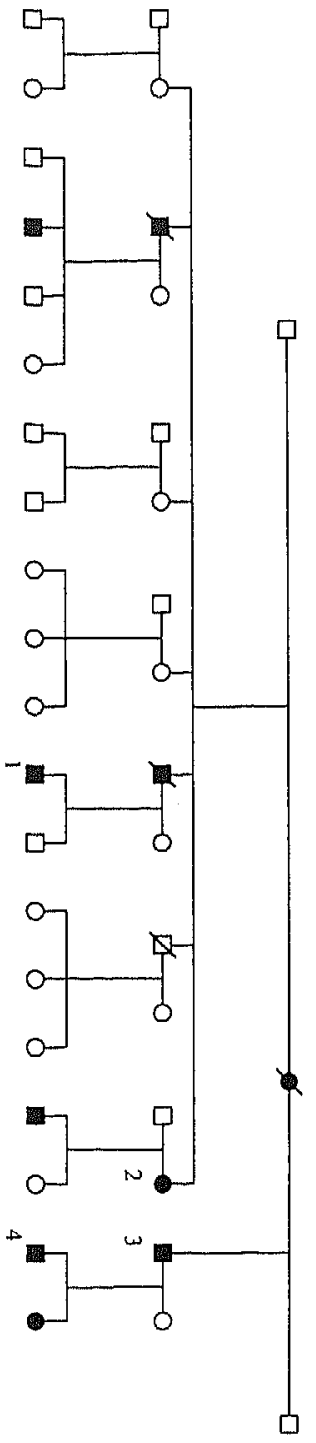

竞 
The center of the ablated zone had a corneal radius on the topographic map of 45.7 / $42.7 \mathrm{D}$ (Figure 6-2). Just on the edge of the pupillary margin (white circle) we see a steepening till $48.0 \mathrm{D}$. Peripheral of that region we see again a flattening towards the edge of the lamellar keratoplasty. We decided to use the transition zone of the effective $5.6 \mathrm{~mm}$ PTK ablation zone as the contact lens bearing area. To determine the radius on that spot, we placed the cursor of the topographic instrument in a horizontal line $2.8 \mathrm{~mm}$ out of the center, nasally and temporally. The radius on that spot was $43.25 \mathrm{D}(7.80 \mathrm{~mm}) 2.76 \mathrm{~mm}$ nasally and the same $2.82 \mathrm{~mm}$ temporally, which was chosen as the base-curve radius of our initial trial lens.

As in standard RGP fitting, the most comfortable RGP fit occurs when the lens rests in a slightly superior position and receives support from the upper lid. The diameter of the contact lens was chosen so that the upper edge of the lens would ride under the upper lid to facilitate lens movement, enhance tear exchange, and increase comfort. The optical zone diameter was $8.5 \mathrm{~mm}$ and the second curve had a radius of $0.5 \mathrm{~mm}$ flatter than the base curve. The third curve had a radius of $1.5 \mathrm{~mm}$ flatter than the base curve, and overall lens diameter was $12.3 \mathrm{~mm}$. Corneal topographic mapping and fluorescein evaluation determined the peripheral radii and the peripheral edge lift, described elsewhere $[1,4]$. During the dispensing visit, the patient was instructed in lens handling and care. Contact lens visual acuity was -0.1 LogMAR (1.25), the same as with spectacles. Follow-up examinations were performed at 2 and 4 weeks and at 6 and 12 months after contact lens fitting. At each follow-up visit, visual acuity was deternined and subjective refraction with the lens in place was performed. Slit-lamp examination was performed with and without fluorescein, and contact lens tolerance was noted. The lens was removed and another slit-lamp evaluation was performed. Subjective refraction, corneal topographic analysis, and pachometry were also performed.

\section{CASE 2.}

This 59-year-old female was referred to us in 1973, 32 years old, diagnosed with Reis-Bückler dystrophy since 1970 . The family history is shown in Figure 6-1. A lamellar transplant was performed in 1973 for the left eye, which was amblyopic, and in 1975 for the right eye. In 1988 a recurrence of the Reis Bückler dystrophy developed in the lamellar transplant of the right eye. Because it was the patients only seeing eye, she waited until 1998 for a phototherapeutic keratectomy. 


\section{Chapter 6}

DOB: $15-10-1963$

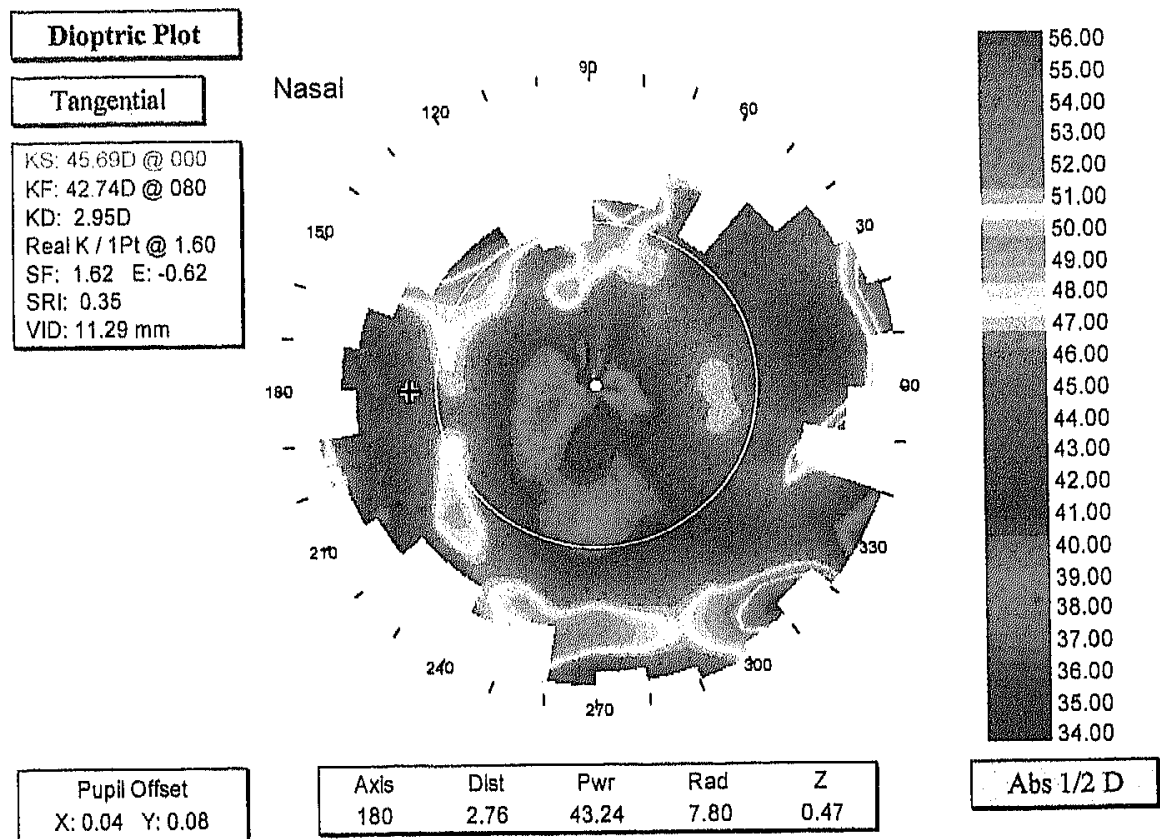

Figure 6-2.

Video topographical color map of patient 1 , six months after phototherapeutic keratectomy. The transition zone of the effective $5.6 \mathrm{~mm}$ PTK ablation zone was used for contact lens bearing, translated into a dioptric power of approximately $43.25 \mathrm{D}(=7.80 \mathrm{~mm})$ on the color map, $282 \mathrm{~mm}$ out of the center (cursor). A trial lens with a back optic zone radius of $7.80 \mathrm{~mm}$ was chosen which was the final lens curve. Between the back surface of the contact lens and the operated cornea, the tear-film compartment neutralizes the corneal surface and replaces it optically with a new surface shaped by the concavity of the contact lens.

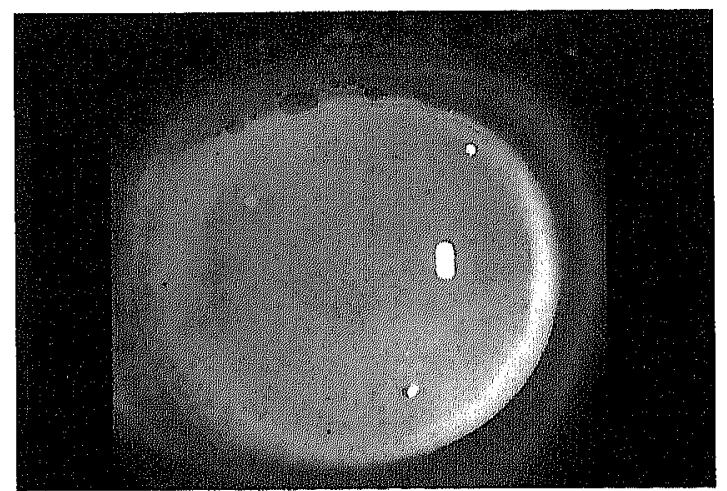

Figure 6-3

Slit-lamp photography after fluorescein staining of patient 1 . The fluorescein pattern shows pooling at the central ablated area. Note the three fenestrations we made in the lens to secure sufficiant tear flow beneath the lens. 


\section{CASE 3.}

This 53 years old male is the brother of case 2 and was referred to us in 1975, 28 years old, diagnosed with Reis-Bückler dystrophy since 1973. The family history is shown in Figure 6-1. A penetrating keratoplasty for his left eye was performed in 1975. In 1998 a recurrence of the Reis-Bückler dystrophy developed in the transplant of the left eye. A PTK operation was performed in 1998 for his left eye and in 1999 for his right. In 2000 a cataract operation was necessary to restore visual acuity in his left eye.

\section{CASE 4.}

This 31 old male is the son of case 3 and was referred to us in 1989, 20 years old, diagnosed with Reis-Bückler dystrophy since that year. The family history is shown in Figure 6-1. A PTK operation was performed on both eyes in the first months of 2000 .

\section{RESULTS}

Six eyes of four patients (one female and three males) underwent excimer laser PTK to ablate the anterior comeal disorder. Two eyes (case 1 and 2) with lamellar- and one eye (case 3 , left eye) with a penetrating keratoplasty had a recurrence of the dystrophy in the transplants. The average number of years between keratoplasty and the recurrence of the Reis-Bückler dystrophy was 13.3 $( \pm \mathrm{sd} 2.5)$ years. Patients waited another $6.6( \pm \mathrm{sd} 4.5)$ years before they asked for the phototherapeutic keratectomy therapy. Visual acuity had to deteriorate to +0.5 LogMAR ( 0.3 in Snellen) before patients wanted corneal surgery again.

Age at time of the PTK treatment ranged from 31 to 58 years (mean age, 41.6). Epithelial healing occurred within one week in all patients. Mild stromal haze was found in the ablation site in all patients during the first year after surgery. No eyes had developed more than mild haze. Subjective improvement in visual acuity occurred in all patients. Six months after PTK we saw a complete quiet cornea in all patients with a trace of haze and no recurrence of the disorder. Follow up after PTK ranged from six to 24 months.

The number of laser pulses used to ablate the disorder ranged from 397 to 499 (mean $472 \pm$ sd 37.8). Preoperative corneal thickness ranged from 530 to 750 $\mu \mathrm{m}$ (mean $635.5 \pm \mathrm{sd} 88.3 \mu \mathrm{m}$ ). Postoperative thickness ranged from 502 to 733 $\mu \mathrm{m}$ (mean $589.7 \pm \mathrm{sd} 104.1 \mu \mathrm{m}$ ). Mean thickness of the ablated fibrous and stromal tissue was $45.7 \pm \mathrm{sd} 33.4 \mu \mathrm{m}$. The treated zone including transition in all patients was 7.0 millimeter. 


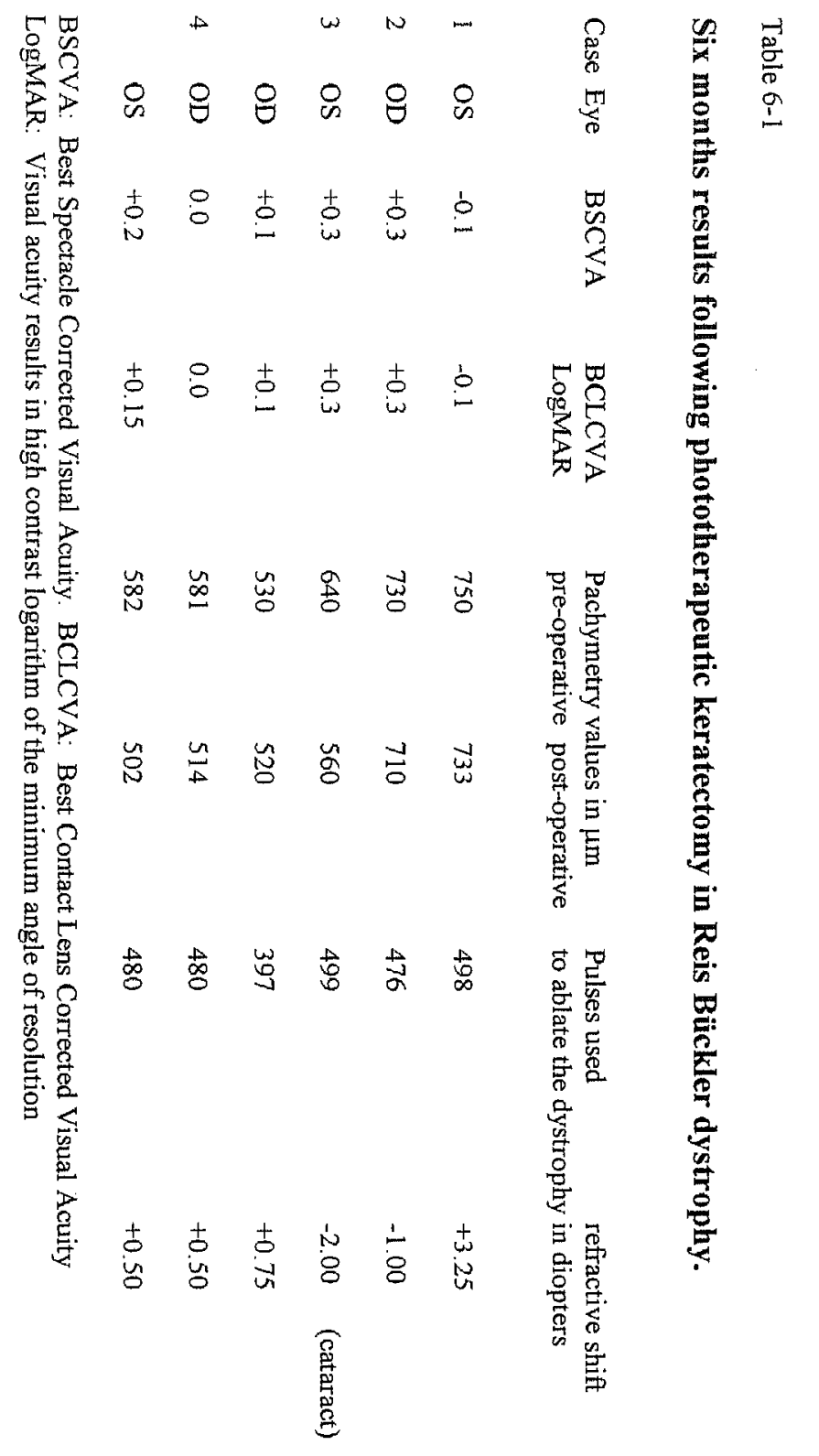


One month after phototherapeutic keratectomy mean best spectacle corrected visual acuity improved to +0.2 LogMAR (0.6), and to +0.15 LogMAR \pm sd $0.16(0.74)$ six months after treatment (Table 6-1). Mean best contact lens corrected visual acuity six months following treatment was +0.125 LogMAR \pm sd $0.23(0.79)$, which was not significantly higher than that obtained with spectacles. Only one eye gained one line of visual acuity with contact lens wear, in the other five eyes we could not improve best spectacle corrected visual acuity.

Only one patient decides to wear the contact lens to correct his anisometropia, caused by the hyperopic shift. The contact lens was tolerated well during sixteen hours daily.

No eyes decreased in best-corrected visual acuity during the study. Eyes showed a mean spherical refractive change of $+0.33 \pm \mathrm{sd} 1.8 \mathrm{D}$. A hyperopic shift was observed in four eyes. Preoperative astigmatism ranged from 1 to $3.5 \mathrm{D}$, averaging $1.54 \pm \mathrm{sd} 1.0 \mathrm{D}$; postoperative astigmatism ranged from 0 to $2.75 \mathrm{D}$, averaging $1.29 \pm \mathrm{sd} 0.9 \mathrm{D}$. Although individuals showed changes in astigmatism with the procedure, taken as a group, there was no change in astigmatism.

\section{DISCUSSION}

Introduction of new procedures must show clinically significant advantages over our present practice before they are accepted as standard procedure. The therapeutic success of excimer laser superficial keratectomy relies on the ability of the cornea to remain smooth without subsequent iatrogenic scarring and to allow adequate epithelial regeneration and adherence to the new corneal surface $[10,26]$. With the introduction of the 193-nm excimer laser, a potentially beneficial therapeutic technique for the precise removal of anterior corneal tissue has gained more indications for the treatment of superficial corneal opacifications, such as Reis-Bückler dystrophy.

We performed PTK in six eyes of four patients from the same family with a Reis-Bückler dystrophy, demonstrating improvement in visual acuity. The efficacy of PTK in patients with Reis-Bückler dystrophy is also described by Hersh and coauthors [10], Lawless and coauthors [13] and Aouni and coauthors [6]. Lawless and coauthors treated two patients with a recurrence in penetrating keratoplasty and Aouni one patient with a recurrence in lamellar keratoplasty. We did both and except of the obviously thicker pre- and postoperative pachymetry values, we noticed no difference between treating patients for the first time or with a recurrence in the graft. When Reis-Bückler dystrophy is present, we usually see a smooth epithelial surface, while the underlying fibrous membrane is nodular and irregular. We recommend ablating through the intact epithelium as 
part of the procedure, rather than first removing the epithelium as done by Aouni. In the fashion we recommend, we believe the epithelium acts as an modulator and can help to leave the postoperative ablated surface smooth, better as has been described with the topical administration of fluids to mask deeper tissue while exposing protruding irregularities during the ablation $[12,15]$. After PTK, the epithelium will slowly smooth irregularities in the keratectomy area [21]. Wu and coauthors [26] found that the reepithelialization took place with variable thickening and in some areas the basal layer projected into the superficial stroma, attempting to fill in minute stromal defects. We demonstrated the same, because the six months visual acuity with and without contact lenses was the same in five out of six eyes (Table), which means a six months postoperative smooth and regular comeal surface in five out of six eyes.

In virgin corneas, the central keratometric readings are used for the selection of the contact lens back optic zone radius, so that the lens power equals the spectacle correction calculated back to comeal plane. The flat central zone in the cornea of patient one, causing a hyperopic shift after PTK, makes it nearly impossible to use commonly applied contact lens fitting techniques. With our lens fitting technique, we used the ablation transition zone, the shoulder of the ablation zone, as a contact lens bearing zone. Hence, the contact lens back optic zone radius may not have any correlation with the central corneal radius i.e. the effective corneal power following PTK. As a result, the vault between the contact lens and the central cornea, i.e. the tear lens, as demonstrated by the fluorescein pattern, induces a shift in refractive error. Schipper and coauthors [19] used the preoperative lens designs as a starting point for determining the contact lens parameters in patients following excimer laser surgery. Our fitting technique consists of using large lens diameters. Few studies have described large diameter contact lens fitting following photo therapeutic keratectomy [5]. Lim and coauthors [14] found mild to moderate RGP lens instability and decentration in patients following excimer laser surgery. The overall diameter of the lenses he used was $9.24 \mathrm{~mm}$. Asymmetrical contact zones between cornea and contact lens will always lead to decentration of the contact lens. We achieved good centration with a large lens diameter and excellent stability on the cornea because centration of large diameter lenses is facilitated by the natural difference in curvature between cornea and sclera. Sufficient flattening of the peripheral zone and fenestration of the lens secure movement and tear exchange.

The long-term effectiveness of excimer laser treatment of patients with Reis-Bückler dystrophy is unknown, but recurrences of the disorder must be included, because we noticed recurrence of the disorder 13.3 years following corneal grafting. In case of a recurrence of the Reis Bückler dystrophy, another excimer laser treatment is possible because thinning of the cornea with another 46 


\section{Recovery of the visual acuity in Reis Bückler dystrophy}

$\mu \mathrm{m}$ should only give a reduction of less than $10 \%$ of initial corneal thickness. The excimer treatment is safe and much less invasive than a lamellar or penetrating graft.

\section{REFERENCES}

1 Beekhuis WH, van Rij G, Eggink FAGJ, Vreugdenhil W, Schoevaart CE. Contact lenses following keratoplasty. CLAO J 1991;17:27-9.

2 Bücklers M. Über eine weitere familiäre hornhoutdystrophie (Reis) Klin Mbl Augenheilk 1949;114:386-97.

3 Duke-Elder S, Leigh AG. Diseases of the outer eye. Cornea and sclera. In: Duke-Elder S, ed. System of ophthalmology. Vol. VIII, part 2. St. Louis, MO: CV Mosby, 1965:927-33

4 Eggink FAGJ, Beekhuis WH. Contact lens fitting following radial keratotomy and other relaxing incisions. Contactologia 1989;11:164-8.

5 Eggink FAGJ, Beekhuis WH. Granular dystrophy of the cornea, contact lens fitting after phototherapeutic keratectomy. Cornea 1995;14:217-22.

6 El Aouni A, Briat B, Mayer F, Saragoussi JJ, Abenhaim A, Assouline M, David T, Pouliquen Y, Renard G. Dystrophie de Reis-Bückler: photoablation thérapeutique au laser Excimer. J Fr Ophthalmol 1998;21:23-7.

7 Gartry D, Muir MK, Marshall J. Excimer laser treatment of corneal surface pathology: a laboratorium and clinical study. Br J Ophthalmol 1991;75:258-69.

8 Geerards AJ, Hassmann E, Beekhuis WH, Remeyer L, van Rij G, Rijneveld WJ. Triple procedure analysis of outcome, refraction, and intraocular lens power calculation. $\mathrm{Br} \mathrm{J}$ ophthalmol 1997;81:774-7.

9 Hall P. Reis-Bücklers dystrophy. Arch Ophthalmol 1974;92:170-3.

10 Hersh PS, Spinak A, Garrana R, Mayers M. Phototherapeutic keratectomy: strategies and results in 12 eyes. Supp Refractive \& Corneal Surg 1993;9:s90-5.

11 Hogan MJ, Wood I. Reis-Bückler's corneal dystrophy. Trans Ophthalmol Soc UK 1982;102:41-57.

12 Kornmehl EW, Steinert RF, Puliafito CA. A comparative study of masking fluids for excimer laser Phototherapeutic keratectomy. Arch Ophthalmol 1991;109:860-3.

13 Lawless MA, Cohen P, Rogers C. Phototherapeutic keratectomy for Reis-Bückler's dystrophy. Supp Refractive \& Corneal Surg 1993;9:s96-8.

$14 \mathrm{Lim} \mathrm{L}$, Siow KL, Chong Chong JS, Tan DTH. Contact lens wear after photorefractive keratectomy: comparising between rigid gas permeable and soft contact lenses. CLAO J 1999;25:222-7.

15 McDonnell PJ, Seiler T. Phototherapeutic keratectomy with excimer laser for ReisBückler's corneal dystrophy. Refract \& Corneal Surg 1992;8:306-10.

16 Moller HU. Granular corneal dystrophy Goenouw type I and Reis-Bücklers'corneal dystrophy One entity? Acta Ophthalmol (Copenh) 1989;67:678-84.

17 Munier FL, Korvatska E, Djemai A et al. Kerato-epithelin mutations in four $5 q 31$ linked corneal dystrophies. Nat Genet 1997;15:247-51.

18 Reis W. Familiäre, fleckige Hornhautentartung. Dtsch med Wschr 1917;43:575.

19 Schipper I, Businger U, Pfarrer R. Fitting contact lenses after excimer laser photorefractive keratectomy for myopia. CLAO J 1995;21:281-4. 


\section{Chapter 6}

20 Smolin G, Thoft RA. The cornea. Boston: Little, Brown, 1990:438-9.

21 Taylor DM, I'Esperance FA, Warner JW, et al. Experimental corneal studies with the excimer laser. J Cataract Refract Surg 1989;15:384-9.

22 Warring GO, Rodriques MM, Laibson PR. Corneal dystrophies. I. Dystrophies of the epithelium. Bowman's layer and stroma. Surv Ophthalmol 1978;23:71-122.

23 Weidle EG. Differentialdiagnose der Hornhautdystrophien vom Typ Groenouw I, ReisBücklers und Thiel-Behnke. Fortschr Ophthalmol 1989;86:265-71.

24 Weidle EG. Klinische und feingewebliche Abgrenzung der Reis-Bücklersschen Hornhautdystrophie. Klin Mbl Augenheilk 1989;194:217-26.

25 Werner LP, Werner L, Dighiero P, Legeais JM, Renard G. Confocal microscopy in Bownan and stromal dystrophies. Ophthalmol 1999;106:1697-704.

26 Wu WCS, Stark WJ, Green WR. Corneal wound healing after 193-run excimer laser keratectomy. Arch Ophthalmol 1991;109:1426-32 


\title{
Enlargement of the photorefractive keratectomy optical zone
}

\author{
Fred A.G.J. Eggink, and W. Houdijn Beekhuis (1) \\ Stephen L. Trokel (2) \\ J. Marius den Boon (3)
}

1. The Rotterdam Eye Hospital, The Netherlands

2. Columbia-Presbyterian Medical Center, New York, USA

3. Medisch Centrum Alkmaar, The Netherlands

JOURNAL OF CATARACT AND REFRACTIVE SURGERY 1996;22:1159-64

Supported in part by a grant of The Rotterdam Eye Hospital Research Foundation. 


\section{ABSTRACT}

Purpose: To evaluate the safety and efficacy of a photorefractive keratectomy (PRK) re-treatment procedure that enlarges the optical zone and treats undercorrection.

Setting: Rotterdam Eye Hospital and Medisch Centrum Alkmaar, The Netherlands.

Methods: This study evaluated 16 eyes that had PRK for myopia with the Summit excimer laser that resulted in a mean undercorrection of -2.82 diopters (D). Patients also reported impaired night vision including difficulty in driving, halos, and stray light and ghost images. These phenomena persisted after spectacle correction of residual refractive error, necessitating further treatment with a larger ablation zone. With a VISX 20/20 excimer laser, the optical zone was enlarged to $6.0 \mathrm{~mm}$ and undercorrection treated with a $6.0 \mathrm{~mm}$ ablation.

Results: At 13.5 months after re-treatment, mean reduction in myopia was $1.70 \mathrm{D}$, resulting in a residual undercorrection of $-1.08 \mathrm{D}$. In seven eyes, final refraction was within $1.00 \mathrm{D}$ of emmetropia. Only two patients continued to report nightdriving problems.

Conclusions: Re-treating undercorrections combined with enlarging the ablation zone resulted in a reduction in myopia from a mean of 2.82 to $1.08 \mathrm{D}$. Subjective reports of halos and stray light images were decreased in all cases. 


\section{INTRODUCTION}

Photorefractive keratectomy (PRK) is a surgical procedure performed on anatomically normal eyes with the objective of reducing myopia and dependence on the use of corrective spectacles or contact lenses. Complications of excimer laser treatment include regression of effect or primary undercorrections, overcorrection of more than 1.00 diopter (D),(1) an increase in refractive astigmatism of more than $1.00 \mathrm{D}$, and an ablation zone decentered more than 1.0 $\mathrm{mm}$. (2) These results may cause significant loss of corrected and uncorrected visual acuities as well as deterioration in visual quality, including glare, halos, and ghost images with decreased contrast acuity and contrast sensitivity. These complications occur in younger patients, even those with normal corrected and uncorrected visual acuities under standard testing conditions, because PRK may create an optical zone that is too small to fill the relatively larger entrance pupil of younger eyes.

Patients with undercorrections, regression, haze, scar, and corneal topographical abnormalities (3-5) may benefit from re-treatment with the excimer laser. Some may have both undercorrections and a relatively small optical zone enlargement.

We studied the results of enlarging the optical zone and treating associated undercorrections in 16 myopic patients who were symptomatic after PRK using an optical zone of $5.0 \mathrm{~mm}$ or less.

\section{MATERIALS AND METHODS}

From September 1992 to September 1993, 385 myopic eyes had PRK with an ExciMed UV200 excimer laser (Summit Technology). All patients provided informed consent before entering the study, which was approved by the Ethics Board of the Rotterdam Eye Hospital. The $193 \mathrm{~nm}$ Summit argon-fluoride laser has a pulse frequency fixed at $10 \mathrm{~Hz}$ and a radiant exposure of $180 \mathrm{MJ} / \mathrm{cm} 2$ and produces a nominal ablation zone of $5.0 \mathrm{~min}$. After epithelial resurfacing, the effective optical zone 1 year after PRK was estimated topographically and biomicroscopically to be 4.4 to $4.6 \mathrm{~mm}$.

One year after PRK, 35 patients had a regression of the result; 16 of these also reported impaired night vision including difficulty driving. Only patients who had minimum of 6 months follow-up after the initial PRK treatment were eligible for re-treatment. In addition to subjective reports of night-driving difficulties, the clinical indications for optical zone enlargement included a stable refraction within $0.25 \mathrm{D}$ for two visits performed 3 months apart and no significant change 
in the accompanying topographical maps (Topographic Modeling System-1, Computed Anatomy).

The 16 patients chosen for re-treatment (Table 7-1) included 12 men and 4 women with a mean age of 38 years, a mean baseline refraction of $-8.01 \mathrm{D} \pm 1.80(\mathrm{SD})$, and a mean undercorrection of $2.82 \pm 1.70 \mathrm{D}$ at $12.8 \pm 3.5$ months after the initial PRK (Table 7-2). At the time of re-treatment, 13 eyes had no haze associated with the regression and 3 had grade 2 haze (on a scale of 4 ). Two patients had a significant increase in refractive cylinder related to a decentered ablation zone. The same surgeon (W.H.B.) performed both the initial PRKs and the re-treatments.

Table 7-1. Patient data before initial PRK

\begin{tabular}{llllll}
\hline & & & \multicolumn{2}{c}{ Refraction } & \\
Patient & Sex & Eye & Sphere & Cylinder & BSCVA \\
\hline 1 & & & & & \\
\hline 2 & M & Right & -7.50 & -0.50 & $20 / 14$ \\
3 & M & Right & -8.50 & -1.00 & $20 / 22$ \\
4 & M & Right & -10.25 & -1.75 & $20 / 20$ \\
5 & M & Left & -10.25 & -1.50 & $20 / 20$ \\
6 & M & Right & -6.50 & -1.00 & $20 / 20$ \\
7 & M & Left & -6.75 & -2.00 & $20 / 24$ \\
8 & F & Right & -8.00 & -1.00 & $20 / 20$ \\
9 & F & Right & -8.75 & -0.75 & $20 / 20$ \\
10 & M & Left & -6.75 & -1.00 & $20 / 17$ \\
11 & F & Left & -5.25 & - & $20 / 17$ \\
12 & M & Right & -5.25 & - & $20 / 20$ \\
13 & F & Left & -9.00 & -0.50 & $20 / 20$ \\
14 & M & Right & -8.25 & -1.25 & $20 / 24$ \\
15 & M & Left & -7.75 & -0.50 & $20 / 20$ \\
16 & M & Left & -6.50 & - & $20 / 24$ \\
& M & Right & -5.00 & - & $20 / 16$ \\
\hline
\end{tabular}

BSCVA $=$ best spectacle-corrected visual acuity

\section{Enlargement technique}

The enlargements and re-treatments were performed with the $193 \mathrm{~nm}$ VISX $20 / 20$ excimer laser at a repetition rate of $5 \mathrm{~Hz}$ and a fluence of 160 $\mathrm{mJ} / \mathrm{cm} 2$. This laser offers the option of a $6.0 \mathrm{~min}$ optical zone and thus the 
possibility of enlarging the optical zone of the achieved spherical correction and treating residual undercorrection. The enlargement and re-treatment involved three steps: removal of the epithelium by the laser; enlargement of the optical zone of the achieved correction; treatment of the undercorrection.

Table 7-2. Results after first PRK

\begin{tabular}{|c|c|c|c|c|c|}
\hline \multirow[b]{2}{*}{ Patient } & \multirow[b]{2}{*}{ Corrected } & \multicolumn{2}{|r|}{ Refraction } & \multirow[b]{2}{*}{ BSCVA } & \multirow[b]{2}{*}{$\begin{array}{l}\text { Night-Vision } \\
\text { Complaints }\end{array}$} \\
\hline & & UCVA & $\begin{array}{l}\text { Diopters } \\
\text { Sph Cyl }\end{array}$ & & \\
\hline I & -7.70 & $20 / 20$ & $-0.75=$ & $20 / 17$ & Moderate \\
\hline 2 & -8.00 & $20 / 60$ & $-2.50-2.00$ & $20 / 24$ & Severe \\
\hline 3 & -8.00 & $20 / 200$ & $-4.25-1.50$ & $20 / 20$ & Severe \\
\hline 4 & -8.00 & $20 / 200$ & $-7.25-0.50$ & $20 / 22$ & Severe \\
\hline 5 & -6.50 & $20 / 200$ & $-5.50-1.00$ & $20 / 24$ & Severe \\
\hline 6 & -7.50 & $20 / 60$ & $-1.50-1.50$ & $20 / 50$ & Severe \\
\hline 7 & -8.00 & $20 / 200$ & $-4.50-0.75$ & $20 / 33$ & Moderate \\
\hline 8 & -8.00 & $20 / 100$ & $-1.50-1.00$ & $20 / 20$ & Moderate \\
\hline 9 & -6.70 & $20 / 150$ & $-3.00-$ & $20 / 28$ & Moderate \\
\hline 10 & -5.20 & $20 / 200$ & $-2.00-0.50$ & $20 / 20$ & Moderate \\
\hline 11 & -5.50 & $20 / 150$ & $-3.50-0.75$ & $20 / 20$ & Severe \\
\hline 12 & -8.00 & $20 / 200$ & $-6.00-$ & $20 / 20$ & Severe \\
\hline 13 & -8.00 & $20 / 24$ & $-0.50-1.00$ & $20 / 20$ & Severe \\
\hline 14 & -7.60 & $20 / 200$ & $-2.50-1.75$ & $20 / 20$ & Moderate \\
\hline 15 & -6.00 & $20 / 30$ & $-1.00-0.75$ & $20 / 20$ & Moderate \\
\hline 16 & -5.00 & $20 / 24$ & $-0.50-0.50$ & $20 / 20$ & Severe \\
\hline
\end{tabular}

UCVA = uncorrected visual acuity; BSCVA = best spectacle-corrected visual acuity

Before the lid speculum was inserted, topical anesthetic drops were given. The epithelium was removed with the laser in the phototherapeutic keratectomy mode and set for a $6.0 \mathrm{~min}$ ablation zone. After the refractive data were programmed into the laser, the patient was positioned for surgery and a lid speculum inserted. The patient was then instructed to fixate on a blinking red light in the delivery system that was coaxial with the laser beam. Laser energy was delivered by depressing the system foot pedal.

During the ablation, the room lights and operating microscope illumination intensity were reduced to the minimum required by the surgeon to maintain laser alignment. The irregular corneal surface reflections made it difficult for the surgeon to see the patient's pupil and for the patient to see the fixation light. The 
darkened operating room allowed the surgeon to monitor the epithelial photoablation by using the operating microscope to observe the fluorescence caused by the ablation. The bluish fluorescence visible as epithelium was being ablated disappeared when the underlying stroma or scar tissue was reached. The photoablation was discontinued as soon as the dark areas were confluent and formed a dark ring around a bluish central area of remaining epithelium.

Epithelial removal of 45 to $70 \mathrm{Am}$ was performed using from 180 to 280 pulses. The remaining central epithelium was removed manually. The previous $5.0 \mathrm{~mm}$ Summit ablation was estimated to produce an average effective optical zone of $4.6 \mathrm{~mm}$. We calculated the achieved correction as equal to the initial refraction before the initial PRK minus the subjective refraction after healing and then programmed the VISX laser for the achieved spherical correction at a 6.0 min diameter ablation zone. The number of pulses needed to reach this achieved correction for the $4.6 \mathrm{~mm}$ zone of the previous surgery was determined by analyzing the iris pattern of the VISX treatment for the achieved spherical correction as specified in the laser's operating manual.

Next, the laser was fired onto a piece of cardboard until the number of pulses required to reach $4.6 \mathrm{~mm}$ was reached. The cornea was then exposed to the laser beam from a beam diameter of $4.6 \mathrm{~mm}$ to the full $6.0 \mathrm{~mm}$ diameter to enlarge the achieved refraction. After the enlargement, a second $6.0 \mathrm{~mm}$ ablation was done to treat undercorrection including astigmatism. Total ablation depth did not exceed $100 \mu \mathrm{m}$ of stromal tissue.

Gentamicin ointment was applied postoperatively, and eyes were patched until re-epithelialization. Fluorometholone drops were instilled five times a day for the first postoperative month and then tapered to three drops a day for I month and twice a day for the third month.

\section{RESULTS}

Mean follow-up after re-treatment was 13.5 months (range 8 to 22 months). At the last visit, mean residual undercorrection was $-1.08 \pm 1.63 \mathrm{D}$, $1.70 \mathrm{D}$ less than the initial undercorrection (Table 7-3). In 8 of the 16 eyes, final refraction was within $1.00 \mathrm{D}$ of emmetropia. The spherical equivalent in the remaining 8 eyes had a mean undercorrection of $2.09 \mathrm{D}(+2.00$ to $-3.25 \mathrm{D})$. Correction of astigmatism was incomplete in 5 of 8 eyes.

Best spectacle-corrected visual acuity (BSCVA) was unchanged in 8 patients and improved one to three Snellen lines in 6 patients after the ablation enlargement (Table 7-3). Two patients lost two lines of BSCVA because of an increase in astigmatism and the presence of ghost images. Night-driving problems 
were reduced or eliminated in all cases. Four patients required another re-treatment for persistent undercorrection.

Table 7-3

Results after re-treatment

\begin{tabular}{|c|c|c|c|c|c|c|c|}
\hline \multirow[b]{2}{*}{ Patient } & \multicolumn{3}{|c|}{ Diopters Corrected } & \multicolumn{2}{|c|}{ Refraction } & & \multirow{2}{*}{ Night-Vision } \\
\hline & Sphere & Cylinder & UCVA & Sphere & Cylinder & BSCVA & \\
\hline 1 & -0.75 & - & $20 / 80$ & +1.25 & - & $20 / 20$ & Mild \\
\hline 2 & -2.50 & -2.00 & $20 / 200$ & -2.50 & -0.75 & $20 / 24^{*}$ & Mild \\
\hline 3 & -4.00 & -1.25 & $20 / 200$ & -5.50 & -0.75 & $20 / 20$ & None \\
\hline 4 & -4.75 & - & $20 / 24$ & -3.00 & -1.00 & $20 / 20$ & Mild \\
\hline 5 & -5.00 & -1.75 & $20 / 200$ & -2.50 & -1.00 & $20 / 20^{*}$ & None \\
\hline 6 & -1.50 & -2.00 & $20 / 40$ & -1.50 & -1.00 & $20 / 22$ & Moderate \\
\hline 7 & -3.50 & - & $20 / 28$ & +1.50 & - & $20 / 20$ & None \\
\hline 8 & -2.00 & - & $20 / 24$ & +1.50 & - & $20 / 20$ & None \\
\hline 9 & -1.00 & - & $20 / 16$ & +0.50 & - & $20 / 16$ & Mild \\
\hline 10 & -2.00 & -0.50 & $20 / 28$ & -2.00 & - & $20 / 20$ & None \\
\hline 11 & -1.50 & - & $20 / 16$ & -1.50 & - & $20 / 16^{*}$ & Moderate \\
\hline 12 & -6.00 & - & $20 / 40$ & -2.00 & - & $20 / 24$ & Mild \\
\hline 13 & 0 & -1.00 & $20 / 24$ & -0.50 & - & $20 / 20$ & None \\
\hline 14 & -2.50 & -1.75 & $20 / 33$ & -1.25 & - & $20 / 20^{*}$ & None \\
\hline 15 & -1.00 & -0.75 & $20 / 50$ & -0.75 & -0.75 & $20 / 24$ & Mild \\
\hline 16 & -1.00 & - & $20 / 16$ & - & - & $20 / 16$ & None \\
\hline
\end{tabular}

$\mathrm{UCVA}=$ uncorrected visual acuity; $\mathrm{BSCVA}=$ best spectacle-corrected visual acuity * Second retreatment

\section{CASE REPORT}

\section{Case 1}

A 37-year-old man had contact lens intolerance in his right eye. In September 1992, he had PRK with the Summit excimer laser for myopia $(-6.50$ $1.00 \times 180$; BSCVA 20/20). Although it was not possible to correct the cylindrical error with the Summit laser, the spherical error of $-6.50 \mathrm{D}$ was treated.

Six months after the initial PRK, the patient's refractive error was -1.00 $-0.50 \times 150$. Fourteen months after the treatment, it was $-5.50-1.00 \times 180$, and BSCVA was 20/24. The patient reported seeing ghost images and having trouble driving. Corneal topography showed an ablation zone decentered by $1.0 \mathrm{~mm}$ 


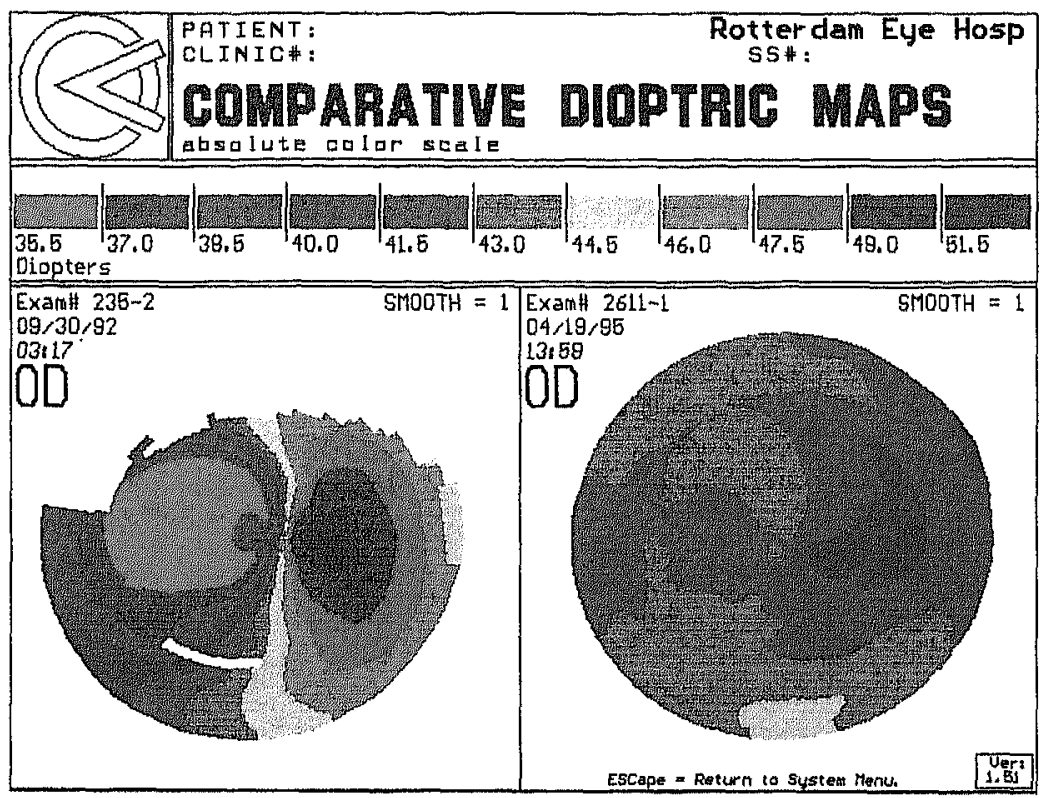

Figure 7-1. Topographical maps of the eye in Case 1. Left: A decentered ablation zone 1 year after the initial PRK. Right: Corneal topography 10 months after enlargement.

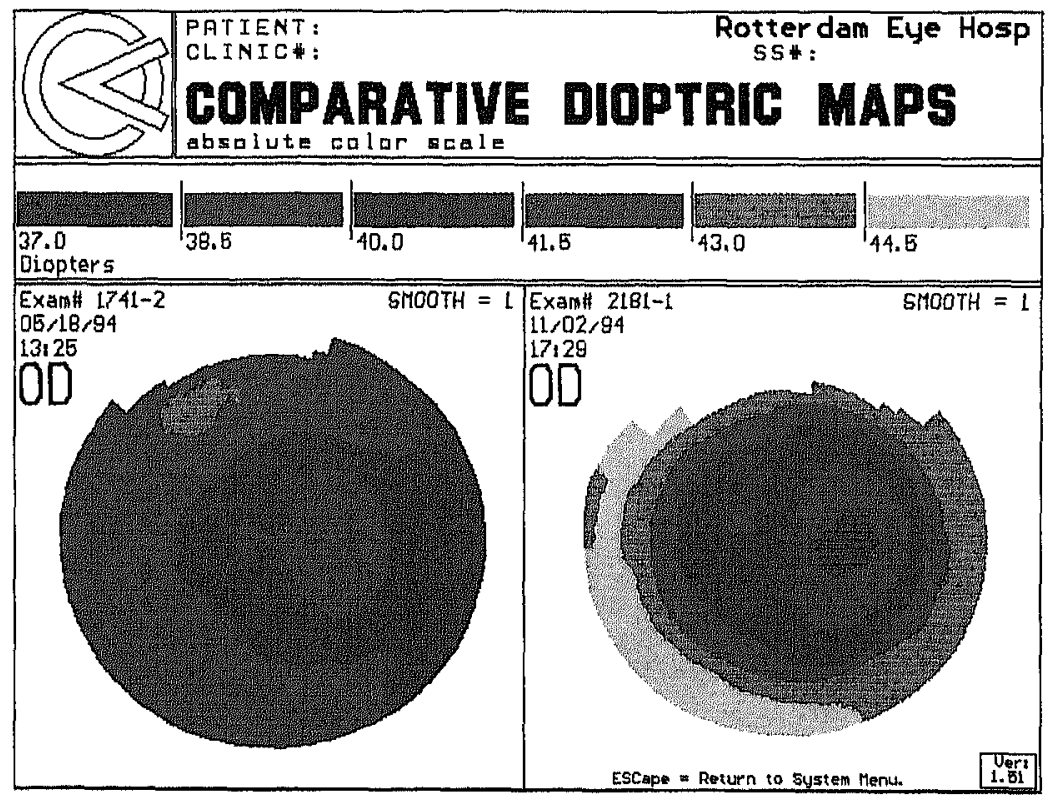

Figure 7-2. Topographical maps of the eye in Case 2. Left: A keyhole ablation pattern 10 months after the initial PRK. Right Corneal topography after enlargement. 
(Figure 7-1). The optical zone diameter of the achieved correction of - $1.00 \mathrm{D}$ was enlarged to $6.0 \mathrm{~mm}$ and the cylinder and spherical refractive error were retreated with the patient's current correction of $5.00-1.75 \times 180$.

One year after the second treatment, BSCVA was 20/20 and refraction, -2.50 $1.00 \times 180$. The patient had no further trouble driving, and ghost images were only present under dim illumination with a wide pupil. Subsequently, the patient had a second repeat PRK for the residual undercorrection. Five months later, the result was acceptable (visual acuity 20/20; sphere -0.75 D).

\section{Case 2}

A 29-year-old man had PRK in the right eye for a sphere of - $5.00 \mathrm{D}$. Ten months later, he had an undercorrection of $-0.50-0.50 \times 180$ and reported extreme difficulty driving at night. We enlarged the zone for the $-4.00 \mathrm{D}$ sphere to $6.0 \mathrm{~mm}$ and re-treated the undercorrection (Figure 7-2). The patient's BSCVA remained unaffected and he no longer had problems driving at night.

\section{DISCUSSION}

Refractive corneal procedures create a change in the refractive power of the central corneal area. Ideally, this newly formed optical area should remain clear and optically regular, approach spherical geometry, and be central around the line of sight. When these conditions are not met, optical complications occur.

The complication rate of PRK is low; however, diagnosing and managing complications that do occur are more complex than many surgeons realize. The most common indications for PRK re-treatment are undercorrection and regression. The main indication for enlarging the optical zone is impaired night vision with difficulty in driving. The degradation of visual function under night conditions is determined by pupil size and ablation zone location and diameter.

Proper patient fixation during PRK and the careful maintenance of ablation zone centration over the entrance pupil by the surgeon are necessary for proper alignment of the new optical zone. The difficult fixation resulting from irregular corneal surface reflections during re-treatments can lead to eccentric ablation and loss of BSCVA. In our series, the use of the no-touch technique led to gross eccentricities in only two eyes, and these occurred during the surgeon's learning curve. With increased surgeon experience, eccentric ablations should not be a problem, even in the absence of eye trackers.

It is difficult to define the best timing between the initial and repeat ablation. Patients often want good visual acuity in the treated eye as soon as possible. On the other hand, the surgeon wants to wait until wound healing is complete. In a primate study by Hanna et al., (6) there was still active tissue 
remodeling 18 months after PRK. We arbitrarily elected to perform the second PRK a minimum of 6 months after the initial procedure.

Medical treatment after reablation was identical to that after the initial operation. In a study by Krueger and coauthors, (7) three of four eyes dramatically regressed after retreatment. We believe that certain patients, even those with mild myopia, may manifest an abnormally marked degree of regression for reasons that are unknown at present.

The enlargement procedure improved the quality of the vision and did not worsen haze. Further developments in excirner laser systems to correct myopia and postoperative treatment should increase the predictability of this technique. We found our re-treatment results moderately encouraging.

In summary, the re-treatment of undercorrection combined with enlargement of the ablation zone resulted in an average reduction in undercorrection from 2.82 to $1.08 \mathrm{D}$. Most important, subjective reports of halos and stray light images decreased in all cases. Seven of the 16 eyes (44\%) had a final refraction within $1.00 \mathrm{D}$ of emmetropia. The percentage of patients who had an uncorrected visual acuity of $20 / 40$ or better increased from 25 to $69 \%$ after re-treatment. The percentage of patients who had loss of BSCVA remained unchanged.

\section{REFERENCES}

1. Maguen E, Salz JJ, Nesburn AB, et al. Results of excimer laser photorefractive keratectomy for the correction of myopia. Ophthalmology 1994; 101:1548-1556; discussion pp 1556-1557

2. Trokel SL, Srinivasan R, Braren B. Excimer laser surgery of the cornea. Am J Ophthalmol $1983 ; 96: 710-715$

3. Epstein D, Tengroth B, Fagerholm P, Hamberg-Nyström $H$. Excimer retreatment of regression after photorefractive keratectomy. Am J Ophthalmol 1994; 117: 456-461

4. Seiler T, Derse M, Pham T. Repeated excimer laser treatment after photoreftactive keratectomy. Arch Ophthalmol 1992; 110: 1230 -1233; erratum p 1708

5. Gibralter R, Trokel SL. Correction of irregular astigmatism with the excimer laser. Ophthalmology 1994; 101: 1310-1314, discussion pp 1314-1315

6. Hanna KD, Pouliquen YM, Savoldelli $\mathrm{M}$, et al Corneal wound healing in monkeys 18 months after excimer laser photoreftactive keratectomy. Refract Corneal Surg 1990; 6:340-345

7. Krueger RR, Talamo JH, McDonald MB, et al. Clinical analysis of excimer laser photorefractive keratectomy using a multiple zone technique for severe myopia. Am j Ophthalmol 1994; 119:263-274 


\title{
Postoperative management and follow up after corneal flap loss following laser in situ keratomileusis
}

\author{
Fred A.G.J. Eggink ${ }^{(1,2)}$ \\ Catharina A. Eggink ${ }^{(2)}$ \\ W. Houdijn Beekhuis ${ }^{(1)}$
}

1. The Eye Hospital Rotterdam

2. University Medical Center "St. Radboud"

Accepted for publication:

Journal of Cataract and Refractive Surgery, 2001;27:

Supported in part by a grant of The Rotterdam Eye Hospital Research

Foundation 
Chapter 8

\section{ABSTRACT}

We present three cases of flap loss within two weeks following unilateral laser in situ keratomileusis (LASIK). In all patients spontaneous regeneration of epithelial layer, covering the ablated stroma, was expected. In two patients best corrected spectacle visual acuity recovered to 20/25 within six months and in one patient we had to fit a contact lens six months after the accident restoring visual acuity to 20/25. First six-month's follow-up and the contact lens fitting technique are described. 


\section{INTRODUCTION}

Laser in situ keratomileusis (LASIK) is increasingly being used for the correction of myopia and hyperopia. 'Recent studies have demonstrated the efficacy, predictability, and safety of LASIK for treating low, moderate, and high myopia. ${ }^{2,3}$ Several early postoperative flap-related complications, months after LASIK are published. ${ }^{4-6}$ Even several dislocations of the flap have been reported. $^{7,8}$ Intraoperative complications such as incomplete cut, perforated lenticule, short flap and the absence of the corneal hinge with a free cap are also reported. ${ }^{9}$ To the best of our knowledge, traumatic corneal flap loss in patients with a complete hinge following uncomplicated LASIK have not been published yet and therapy after corneal flap loss is under discussion. Lam and coauthors published one case in which he amputated the flap at the hinge after several dislocations. ${ }^{8}$ We describe three cases of flap loss in the first weeks following LASIK. Flap loss occurred in one patient following uncomplicated LASIK and in two patients with a free cap treated for myopia by experienced surgeons. The therapy we used to restore visual acuity is described.

\section{MATERIAL AND METHODS}

\section{CASE I.}

In March 2000, we treated a 37-year-old woman using LASIK for her right eye. Preoperative refractive error was Sph $-4.50 \times$ Cyl -3.0 axis $170^{\circ}$ with a visual acuity of $20 / 20$. Keratometry values were: $44.87 \mathrm{D}$ x $87^{\circ} / 42.00 \mathrm{D} x$ $177^{\circ}$. Pachymetry was $542 \mu \mathrm{m}$.

Last years she experienced increasingly discomfort during the wear of her rigid gas permeable (RGP) contact lenses, probably caused by insufficient tear quality. Schirmer test showed $6 \mathrm{~mm}$ tear flow in 5 minutes. Tear breaking up time was less than 5 seconds. During surgery with the Automated Corneal Shaper (ACS; Chiron Vision, Claremont, CA), we noticed a relatively thin flap, and the laser procedure with the Baush \& Lomb Technolas 217 Excimer laser was uncomplicated. After ablation, the flap was replaced onto the bed using an irrigation cannula and dried in position for approximately 5 minutes. Before removal of the lid speculum, one drop of Polymyxine $B$ was placed on the eye. The flap position was verified by slit-lamp microscopy approximately 10 minutes after surgery, and the patient was discharged with a transparent eye shield for protection and instructions to avoid rubbing the operated eye for 2 weeks.

One day after the operation the patient told us that she experienced increasing pain, five hours after her LASIK treatment. Her eye kept tearing and 
Chapter 8

she could not avoid extreme blinking. There was no history of eye rubbing or noncompliance with the eye-shield use. She presented with central epithelial defect of $5.0 \mathrm{~mm}$. Initially we interpreted this as an epithelial defect on the flap but slit-lamp inspection showed no interface formed by corneal stroma and the stroma of the flap, nor hinge remnant: we concluded flap loss, and administered Polymyxine $\mathrm{B}$, three times daily and Ketorolac 5 times daily during the first week. One week postoperatively the visual acuity was $20 / 125$, epithelial layer was closed but still highly irregular. One month postoperatively her visual acuity was still 20/125 and we saw a haze grade II on which we performed a PTK (15 $\mu \mathrm{m}$ with a $6.0 \mathrm{~mm}$ zone) after debridement of the epithelial tissue.

Six months after the operation her visual acuity improved with Cyl $-5.0 \mathrm{x}$ 22 to 20/50 and the haze is reduced to grade I. Because she had a car parking accident, she requested restoring binocular vision. We decided to fit a rigid gas permeable contact lens.

\section{Contact Lens Fitting}

We used corneal topography color-coded map in the tangential absolute scale (Alcon Eye Map, Alcon Laboratory inc. Software Version 5.50) to localize the ablation transition zone for choosing the base curve of the first trial lens. We selected the base curve radius of the trial-lens to provide a large bearing zone in the region on the border of the ablation zone. To determine the radius on that spot, we placed the cursor of the topographic instrument on the transition of the ablation zone, $3.27 \mathrm{~mm}$ nasally of the fixation center. (Figure 1 , cursor) The radius on that spot was used to select the initial trial lens with an identical back optic zone radius of $8.25 \mathrm{~mm}$. A custom made tetra-curved trial lens (NKL contact lenses, Emmen, The Netherlands) was used with an back optic zone diameter of $8.5 \mathrm{~mm}$. We used a very high Dk contact lens material (FluoroPerm 151 with a Dk of 151; Paragon Vision Sciences, Mesa AZ, USA) to avoid corneal edema (Table 8-1). Wetability of the contact lens was poor due to a low tear volume.

Best contact lens corrected visual acuity was $20 / 25$. Visual acuity, pachymetry and haze results six months after flap loss are listed in Table 8-2. The contact lens was tolerated during working hours, eight to ten hours daily. The fluorescein pattern is shown in Figure 8-2. 


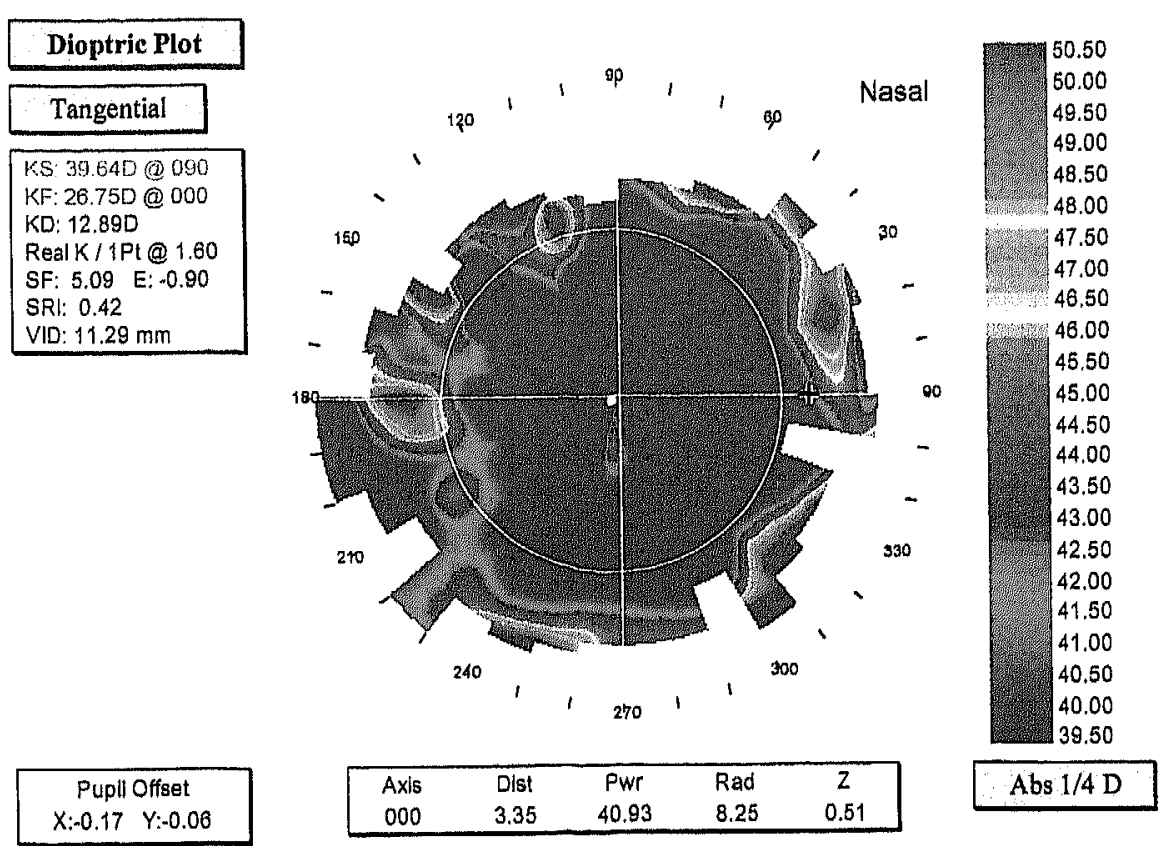

Figure 8-1.

Video topographical color map of case 1 . The edge of the ablation zone is used as a bearing zone for the contact lens. The dioptric power of that zone is approximately $40.84 \mathrm{D}(=8.26$ $\mathrm{mm}$ ) on the color map (cursor). A trial lens with a base curve of $8.25 \mathrm{~mm}$ was chosen which was the final lens curve

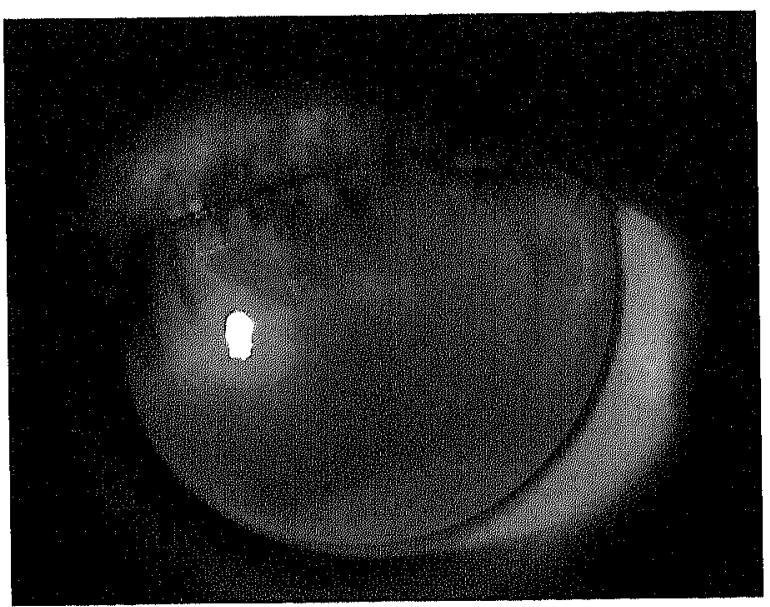

Figure 8-2

Slit-lamp photography after

fluorescein staining of case 1

The fluorescein pattern shows displacement of huorescein over the edge of the ablation zone and fluorescein pooling at the central flat area The wettability of the contact lens is poor, demonstrated by the depleted tear layer under the lens at $1 /$ o'clock. Patient used artificial tears supplements to reduce tear deficiency. 
Chapter 8

Table 8-1.

Contact lens specifications.

Right eye

\begin{tabular}{|c|c|}
\hline Material & $\begin{array}{l}\text { Fluoroperm } 151 \text { (Paragon Vision Sciences. USA. } \\
\text { produced by NKL contact lenses. the Netherlands) }\end{array}$ \\
\hline Permeability (modified Fatt method) & 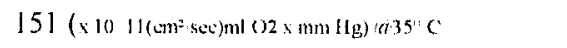 \\
\hline Refractive index & 1,471 \\
\hline Back optic zone radius (mm) & 8.25 \\
\hline Prescription (spherical) & -3.00 \\
\hline Diameter $(\mathrm{mm})$ & 11.5 \\
\hline Back optic zone diameter $(\mathrm{mm})$ & 8.5 \\
\hline Thickness (mm) & 0.16 \\
\hline Peripheral curves (mm) & $8.75 / 9.75 / 12.50$ \\
\hline Edge design & ski top bevel \\
\hline
\end{tabular}

CASE II.

A 25 year old male had an uncomplicated LASIK treatment in November 1999 for his right eye. In February 2000 he was treated for his left eye. Preoperative refractive error was $\mathrm{Sph}-5.50 \times \mathrm{Cyl}-1.00$ axis $170^{\circ}$ with a visual acuity of $20 / 20$. He had a contact lens history of 9 Years. Keratometry values before LASIK were: $43.0 \mathrm{D} \times 110^{\circ} / 42.20 \mathrm{D} \times 20^{\circ}$. Pachymetry was $600 \mu \mathrm{m}$. During surgery with the Krumeich Barraquer Microkeratome (Summit Technology, Waltham, MA), we produced a free cap. The laser procedure with the Summit APEX Plus Excimer Laser (Summit Technology, Waltham, MA) was uncomplicated. After ablation, the cap was repositioned onto the ablated bed using the marked zone and dried in position for approximately 5 minutes. Before removal of the lid speculum, chloramphenicol eyedrops $0.5 \%$ were instilled. The flap position was verified by slit-lamp microscopy approximately 10 minutes after surgery, and the patient was discharged with a transparent eye shield for protection and instructed to avoid rubbing the operated eye for 2 weeks. 


\section{Postoperative management after flap loss in LASIK patients}

One day after the operation he presented with an uncorrected visual acuity of 20/25 and the cap was in situ. Five days after the operation the situation was unchanged and the cornea remained clear. Nine days after operation of his left eye, an elastic wrapper was shot accidentally onto his eye, causing loss of the cap. His eye was patched with antibiotic eye ointment (chloramphenicol $0.5 \%$ ) and was prescribed three times daily in combination with fluormetholon 2 times daily. Five days after the trauma the epithelial tissue was closed. We increased the fluormetholon to 6 times daily for the first three weeks, phased out in the next month. His one month uncorrected visual acuity was 20/50 and 20/30 with Sph $-0.5 \mathrm{Cyl}-1.0$ axis $160^{\circ}$. He had a haze grade I, and the pachymetry was 455 $\mu \mathrm{m}$.

Six months after the trauma his uncorrected visual acuity was still 20/50 and with Sph $-2.50 \mathrm{Cyl}-0.75$ axis $75^{\circ} 20 / 25$. He had a mild haze grade I, and the pachymetry value was $401 \mu \mathrm{m}$. His keratometry values were $36.00 \mathrm{D} \times 131^{\circ}$ / $37.37 \mathrm{D} \times 41^{\circ}$.

\section{CASE III.}

A 39-year-old female had an uncomplicated LASIK treatment in may 2000 for her left eye and was treated for her right eye two weeks later. She had contact lens intolerance due to her job in riding-school. Preoperative refractive error of her right eye was $S p h-10.50$ with a visual acuity of 20/20; keratometry values before LASIK were: $44.20 \mathrm{D} \times 0^{\circ} / 45.50 \mathrm{D} \times 90^{\circ}$. Pachymetry was 546 $\mu \mathrm{m}$. During surgery with the Krumeich Barraquer Microkeratome (Summit Technology, Waltham, MA), we produced a free cap. The laser procedure with the Summit APEX Plus Excimer Laser (Summit Technology, Waltham, MA) was continued and uncomplicated. After ablation, the cap was repositioned onto the ablated bed using the marked zone, and dried in position for approximately 5 minutes. Before removal of the lid speculum, a soft bandage contact lens was applied (Bausch \& Lomb) and chlooramphenicol eyedrops $0.5 \%$ were instilled. The position of the cap was verified by slit-lamp microscopy approximately 10 minutes after surgery. The patient was discharged with a transparent eye shield for protection and instructed to avoid rubbing the operated eye for 2 weeks.

The same evening she presented with the soft bandage lens and the cap in her lens case. She had experienced ocular discomfort from the contact lens and had removed the lens, including the cap. We repositioned the edematous cap, secured with four interrupted 10-0 nylon sutures.

One day after this operation she presented with a visual acuity of $20 / 200$ and the cap was in situ. Antibiotic eye drops (chloramphenicol $0.5 \%$ ) were prescribed six times daily for the first week in combination with ketorolac $0.5 \%$, 4 times daily during the first two days. Five days after the operation there was a 


\section{Chapter 8}

little gap between the cap and the stroma temporally and dehiscence of the cap at the nasal side. Epithelial ingrowth was noted at the site of cap separation. The patient was taken to the excimer laser suite, and under view of the laser microscope, the stitches were removed and the cap was reflected. A sheet of epithelial cells was scraped off the undersurface of the cap and the stromal bed with a sterile blade. The patient was observed for 1 hour, and slitlamp biomicroscopy showed that the cap was in place. The eye shield was given and chloramphenicol $0.5 \%$ was prescribed four times daily. Three days after scraping the cap was still in place and we continued antibiotic eye drops therapy in combination with fluormetholon 3 times daily. Five days after the scraping she again presented with a loss of the cap. There was no pain but the feeling of the eye was different compared to before. Visual acuity was finger counting at two meters and there was a central epithelial defect, which closed during the next five days. We continued the fluormetholon 3 times daily during the first month, phased out during the next month. Uncorrected visual acuity improved to 20/40 after one month. There was mild Haze grade I and the pachymetry value was $358 \mu \mathrm{m}$.

Six months after the cap loss her uncorrected visual acuity was still 20/40 and improved to $20 / 25$ with $\mathrm{Sph}-0.50 \mathrm{Cyl}-2.0$ axis $15^{\circ}$. She had a mild Haze grade 0.5 and the pachymetry value was $365 \mu \mathrm{m}$. Her keratometry values were $39.00 \mathrm{D} \times 110^{\circ} / 37.50 \mathrm{D} \times 16^{\circ}$.

All patients developed spontaneously epithelial regeneration and best spectacle corrected visual acuity in all eyes was $20 / 50$ or better (Table 8-2).

Table 8-2

Six months results after flap loss.

\begin{tabular}{lcccc}
\hline $\begin{array}{l}\text { Case BSCVA } \\
\text { No }\end{array}$ & $\begin{array}{l}\text { Haze } \\
\text { grading } \mu \mathrm{m}\end{array}$ & Keratometry & \multicolumn{2}{c}{ Six months results } \\
& & & & Subjective refractive results \\
\hline 1. $20 / 50$ & 1 & 443 & $37.24 \times 22^{\circ} / 43.69 \times 120^{\circ}$ Plan $\mathrm{C}-5.0 \times 22^{\circ}$ \\
2. $20 / 25$ & 1 & 401 & $37.37 \times 41^{\circ} / 36.00 \times 131^{\circ}-2.50 \mathrm{C}-0.75 \times 75^{\circ}$ \\
3. $20 / 25$ & 0.5 & 365 & $39.00 \times 110^{\circ} / 37.50 \times 16^{\circ}$ & $-0.50 \mathrm{C}-2.0 \times 15^{\circ}$
\end{tabular}

BSCVA $=$ best spectacle corrected visual acuity 


\section{DISCUSSION}

LASIK flap complications can be classified in intraoperative- and postoperative complications. ${ }^{4,10-13}$ The traumatic loss of a corneal flap by the patient is obvious postoperative. Preventive strategies, such as using eye shields during the first 24 hours and during two weeks of follow-up while overnight sleep is common and also ordered by us. Oral and written instructions are given to refrain from rubbing but we do not know if patients obey.

Loss of the flap is relatively rare, now that a flap is used in the LASIK procedure instead of a cap. In recent large LASIK studies with over 1000 eyes, no cases of corneal flap loss are reported. ${ }^{4,5}$ Traumatic loss of the corneal flap is a serious, vision threatening complication because severe irregular astigmatism and unpredictable refractive change can occur. ${ }^{14}$

In case one, we can only guess as to the causes of the flap loss. One explanation could have been that the flap displaced several hours after LASIK surgery causing eye pain and the hinge might be torn due to repeated involuntary eye squeezing. Another explanation could have been a poor adherence of the corneal flap to the stromal bed as a result of an overhydration of the stromal bed and / or dehydration of the relatively thin flap. A recent report highlights the ease with which the LASIK flap can be dissected as late as one year after surgery. ${ }^{15}$ Newer microkeratome models have a superior placed hinge that possibly will reduce postoperative flap complications. ${ }^{16}$ Over-refraction with a gas-permeable contact lens corrected visual acuity in case I to 20/25, suggesting that loss of spectacle-corrected visual acuity in this case was primarily because of corneal irregular change from the corneal flap loss rather than related to the corneal haze. It is essential to consider the difficulties in fitting contact lenses in corneas with significant alterations in comeal architecture and function, following refractive surgery. ${ }^{17,18}$ RGP contact lenses are considered a better choice for fitting surgically changed corneas. ${ }^{19}$

The second patient obtained a good visual acuity five days after LASIK surgery. Traumatic dislocation of the flap is described during eye surgery and in a patient with motor vehicle accident, seventeen months after LASIK, 20,21 Traumatic loss of the corneal cap following LASIK is sparse in literature. Even the incidence of spontaneous corneal flap displacement is rare ${ }^{10}$ and occurs most commonly within the first 24 hours after LASIK, before the epithelium has had time to heal over the lamellar entry site. ${ }^{11}$ The wound healing process along the interface is much slower and still continuing at 9 months after LASIK. 22 The accident took place on day nine after LASIK surgery and nothing could 


\section{Chapter 8}

prevent the loss of the cap. We hypothesize that the same could have happened as long as nine months after surgery.

In the third case the patient experienced discomfort probably due to a suboptimally fitted bandage lens which she took out herself, including the cap. The use of a bandage contact lens to reduce the occurrence of postoperative flap wrinkling has been reported recently. ${ }^{23}$ Several authors ${ }^{5,}{ }^{14}$ report another dislodgment of the flap hours after a bandage contact lens was placed. We only use a bandage contact lens in selected cases such as in those following enhancement procedures. The results have been encouraging, however as illustrated in case 3, care should be exercised in the choice and fitting of the contact lens. Prior to discharge, now we wait at least 1 hour, and all patients are questioned to ensure there is no ocular discomfort. In pursuance of our case, we discuss the use of a bandage contact lens to secure a free cap.

Our findings disagree with Petersen and Seiler ${ }^{12}$ that fixation of the flap with two interrupted sutures can be advisable in patients with postoperative dislodged flaps. Kim et al. also noticed interfacial epithelial ingrowth along the lenticule edges in a patient whose cap was sutured peroperatively with four interrupted sutures after loss. ${ }^{10}$ Suturing the cap in our patient was probably the cause of a small gap between stroma and cap, which resulted in epithelial ingrowth. It may be advisable to prevent epithelial ingrowth under the free cap to use a running suture to secure the cap. Suturing a free cap is uncomfortable for the patient and can result in postoperative astigmatism but patients can not take the cap off their eyes. The cause of the loss of the cap in patient 3 must have been a traumatic one because three days following scraping the flap was in situ and normally epithelial tissue is healed within ten days. We are taking into account that the epithelial tight junctions protect the cap from spontaneously displacement after the first 24 hours following surgery.

Risks associated with creating the flap by means of the microkeratome, include thin flaps or a free cap. Lin and Maloney ${ }^{4}$ reported the results of 1019 eyes in which four patients had thin flaps in which the procedure not was aborted, and ten free caps in which only one procedure was aborted. We had one thin flap and two free caps in which we continued the LASIK procedure. Traumatic loss of a free cap nine days after surgery is not astonishing, but how many patients are walking around with a free cap in position and are not aware of the potential risks? The relative paucity of wound healing at the stromal interface after LASIK makes the corneal flap amenable to lifting for enhancement months after the initial surgery, and may render the flap susceptible to late dislocation or loss with trauma. The number of cases presenting with perioperative corneal flap loss will probably increase because LASIK treatments are popular. Flap related complications rarely lead to a permanent decrease in best spectacle corrected visual acuity with appropriate 
treatment. The incidence of flap related complications can be decreased by the physicians' experience but the patient behavior will always be an uncertain factor.

In summary, we have presented a series of 3 patients with flap loss and discussed the different management strategies to restore best corrected visual acuity. Preventing of postoperative flap loss can be improved by preoperative discussion with LASIK candidates of the potential for traumatic dislocation or loss of the LASIK flap.

\section{REFERENCES}

1. Buratto L, Brint SF, LASIK: Principles and Techniques. Thorofare, NJ: Slack, 1998 $113-132$

2. El-Maghraby A, Salah T, Waring GO III, et al. Randomized bilateral comparision of excimer laser in situ keratomileusis and photorefractive keratectomy for 2.50 to 8.00 diopters of myopia. Ophthalmology 1999;106:447-457

3. Stulting RD, Carr JD, Thompson KP, Warring III GO, Wiley WM, Walker JG Complications of laser in situ keratomileusis for the correction of myopia. Ophthalmol 1999; $106: 13-20$

4. Lin RT, Maloney RK. Flap complications associated with lamellar refractive surgery. Am J of Ophthalmol 1999;127:202-204

5. Gimbel HV, Anderson Penno EE, van Westenbrugge JA, Ferensowicz M, Furlong MT. Incidence and management of intraoperative and early postoperative complications in 1000 consecutive laser in situ keratomileusis cases. Ophthalmology $1998 ; 105: 1839-1847$

6. Knorz MC, Jendritza B, Hugger P, Liermann A. Komplikationen der Laser-in-situKeratomileusis (LASIK) Ophthalmologe 1999;96:503-508

7. Leung AT, Rao SK, Lam DS. Traumatic partial unfolding of laser in situ keratomileusis flap with severe epithelial ingrowth. J Cataract Refract Surg 2000;26 : 135-139

8. Chaudhry NA, Smiddy WE. Displacement of corneal cap during vitrectomy in a post LASIK eye. Retina 1998; 18 :554-555

9. Gulani AC Letter to the Editor. Ophthalomol 1999;106:1457-1458

10. Kim EK, Choe CM, Kang SJ, Kim HB. Management of detached lenticule after in situ keratomileusis. J Refract Surg 1996;12:175-179

11. Lam DSC, Leung ATS, Wu JT, Cheng ACK, Fan DSP, Rao SK, Talamo JH, Barraquer C. Management of severe flap wrinkling or dislodgment after laser in situ keratomileusis. J Cataract Refract Surg 1999;25:1441-1447

12. Petersen H, Seiler T. Laser-in-situ-Keratomileusis (LASIK). Intraoperative und postoperative Komplikationen. Ophthalmologe 1999;96:240-247

13. Hoffman CJ, Rapuano CJ, Cohen EJ, Laibson PR. Displacement of corneal lenticule after automated lamellar keratoplasty. Am J Ophthalmol 1994;1 $18: 109-111$

14. Wilson SE. LASIK: Management of common complications. Cornea 1998;17:459467 


\section{Chapter 8}

15. Özdamar A, Aras C, Bahçecioglu H, Sener B. Secondary laser in situ keratomileusis 1 year after primary LASIK for high myopia. J Cataract Refract Surg 1999;25:282-288

16. Walker MB, Wilson SE. Lower intraoperative flap complication rate with the Hansatome microkeratome compared to the Automated Corneal Shaper. J Refract Surg $2000 ; 16: 79-82$

17. Eggink FAGJ, Beekhuis WH. Contact lens fitting following radial keratotomy and other relaxing incisions. Contactologia 1989;14:164-168

18. Eggink FAGJ, Beekhuis WH. Granular dystrophy of the cornea. Contact lens fitting after phototherapeutic keratectomy. Cornea 1995;14:217-222

19. Eggink FAGJ, Beekhuis WH, Nuijts RMMA. Fitting spherical RGP contact lenses in LASIK patients for the correction of multifocal corneas. Submitted.

20. Chaudhry NA, Smiddy WE. Displacement of corneal cap during vitrectomy in a postlasik eye. Retina 1998; 18:554-555

21. Lemley HL, Chodosh J, Wolf TC, Bogie CP, Hawkins TC. Partial dislocation of laser in situ keratomileusis flap by air bag injury. J Refract Surg 2000; 16:373-374

22. Kato T, Nakayasu Y, Watanabe Y, Kanai A. Corneal wound healing following laser in situ keratomileusis (LASIK): a histopathological study in rabbits. Br J Ophthalmol $199 ; 83: 1302-1305$

23. Pannu JS. Incidence and treatment of wrinkled corneal flap following LASIK (letter) J Cataract Refract Surg 1997; 23:695-696 


\section{Contact lens fitting in a patient with keratectasia after laser in situ keratomileusis}

Fred A.G.J. Eggink and W. Houdijn Beekhuis

The Rotterdam Eye Hospital, Rotterdam, The Netherlands Journal of Cataract and Refractive Surgery, 2001;27:1119-23. Supported in part by a grant of The Rotterdam Eye Hospital Research Foundation. 
Chapter 9

\section{ABSTRACT}

We present a case of unilateral iatrogenic keratectasia developing 15 months after bilateral laser in situ keratomileusis using a broad-beam excimer laser (Bausch \& Lomb Keracor 116) to treat - $3.5-1.5 \times 85$ diopters of myopia. Preoperative pachometry of the eye measured 450 $\mu \mathrm{m}$ without topographical changes suggesting keratoconus or forme fruste keratoconus. Contact lens fitting to provide $20 / 25$ visual acuity is described. 


\section{INTRODUCTION}

Keratectasia following laser in situ keratomileusis (LASIK) for myopic eyes has been reported by Wellish and coauthors, ${ }^{(1)}$ Speicher and Göttinger, ${ }^{(2)}$ and Seiler and Quurke. ${ }^{(3)}$ Keratectasia is an insidious complication of LASIK, occurring months after an original procedure with an ostensibly safe outcome. ${ }^{(4)}$ Some authors describe their concern about the substantial reduction in the biomechanically effective stress-bearing thickness of the cornea by the residual bed after LASIK treatment. ${ }^{(5)}$ An undeveloped form of keratoconus is likely to be hastened by the removal of central corneal tissue.

Most reports about progressive corneal ectasia following LASIK involve patients treated for myopia higher than -6.0 diopters (D). ${ }^{(6,7)} \mathrm{We}$ report a case of progressive keratectasia after LASIK treatment of low myopia and the problems of contact lens fitting for visual rehabilitation.

\section{MATERIAL AND METHODS}

A 32-year old white male presented for a second opinion following refractive surgery. The patient had worn soft contact lenses for 2 years but became intolerant to the contact lens solutions. In 1998, he was referred to an excimer laser clinic somewhere else in Europe. Preoperative examination revealed a manifest and cycloplegic refraction of $-3.5-1.5 \times 85$ in the right eye and $-4.5-0.5 \times 95$ in the left eye, yielding a best corrected visual acuity (BCVA) of 20/20 in both eyes. Preoperative pachometry was $450 \mu \mathrm{m}$ in the right eye and $460 \mu \mathrm{m}$ in the left eye. Central keratometry measured $44.5 \times 85 / 46.0 \times 175$ and $44.5 \times 95 / 45.0 \times 5$, respectively. Corneal topography showed a regular bow-tie pattern.

In July 1998, the patient had bilateral LASIK by an experienced surgeon using the Bausch \& Lomb Technolas 116 excimer laser. The Moria One microkeratome was used to create $160 \mu \mathrm{m}$ flaps. The laser was programmed for the patient's manifest refraction with a zone diameter of $7.0 \mathrm{~mm}$, and 387 pulses were applied to his right eye first; the theoretical ablation depth was $77.75 \mu \mathrm{m}$. The same blade was used for both eyes. The laser was programmed for the left eye with a zone diameter of $7.0 \mathrm{~mm}$, and 318 pulses applied; the theoretical ablation depth was $71.5 \mu \mathrm{m}$ (Table 9-1). Topical ofloxacin, prednisolone acetate, and preservative-free artificial tears were used 5 times a day for 10 days. Eye shields were worn at bedtime for the first week after treatment. Ten days after surgery, the uncorrected visual acuity (UCVA) was 20/20 in both eyes. 


\section{Chapter 9}

Table 9-1

Multizone Ablation Profile

\begin{tabular}{|c|c|c|c|c|c|c|c|c|}
\hline \multicolumn{3}{|c|}{ Right Eye } & \multicolumn{6}{|c|}{ Left Eye } \\
\hline & $\begin{array}{l}\text { Amount } \\
\text { (5) }\end{array}$ & $\begin{array}{l}\text { Sph. } \\
\text { (D) }\end{array}$ & $\begin{array}{l}\text { Diamete } \\
(\mathrm{mm})\end{array}$ & Microns & $\begin{array}{l}\text { Amount } \\
(\%)\end{array}$ & $\begin{array}{l}\text { Sph. } \\
\text { (D) }\end{array}$ & $\begin{array}{l}\text { Diameter } \\
(\mathrm{mm})\end{array}$ & Microns \\
\hline Pre-treatment & $50 \%$ & -2.0 & 2.5 & $4.00 \mu \mathrm{m}$ & $50 \%$ & -2.5 & 2.5 & $5.25 \mu \mathrm{m}$ \\
\hline First Zone & $82.5 \%$ & -3.5 & 6.0 & $51.00 \mu \mathrm{m}$ & $60 \%$ & -3.0 & 5.0 & $29.00 \mu \mathrm{m}$ \\
\hline Second Zone & $12.5 \%$ & -0.5 & 7.0 & $10.50 \mu \mathrm{m}$ & $30 \%$ & -1.5 & 6.0 & $22.00 \mu \mathrm{m}$ \\
\hline Third Zone & $10 \%$ & -0.5 & 7.0 & $10.50 \mu \mathrm{m}$ & & & & \\
\hline Cylinder & & & & $12.25 \mu \mathrm{m}$ & & & & $4.75 \mu \mathrm{m}$ \\
\hline Total Microns & & & & $77.75 \mu \mathrm{m}$ & & & & $71.50 \mu \mathrm{m}$ \\
\hline
\end{tabular}

In January 2000, the patient complained of dramatically decreased visual acuity, with diplopia developing over the past month in the right eye. The patient sought a second opinion and was examined in March 2000 in our refractive surgery department. The UCVA in the right eye was finger counting at 5 feet, improving to $20 / 125$ with $-3.0-1.75 \times 65$. The BCVA in the left eye was $20 / 25$ with a sphere of -1.0 . Corneal topography (Alcon Laboratory Inc:, software version 5.50.03) showed an area of central steepening of $20.0 \mathrm{D}$ within the pupil region of the right eye (Figure 9-1) and a paracentral area of steepening with a $6.0 \mathrm{D}$ difference within the ablated area in the left eye. Postoperative pachometry (Pach-pen XL, Mentor O\&O Norwell) was $355 \mu \mathrm{m}$ in the right eye and $400 \mu \mathrm{m}$ in the left eye. Central keratometry measured $46.12 \times 69 / 49.5 \times 159$ and $42.37 \times 37 / 41.75 \times 127$, respectively (Topcon KR 3500 autokeratorefractometer). The cornea in both eyes was clear and the flaps were well centered.

In the right eye, a central thinning of the cornea was visible over the visual axis. The center of the ectasia and the ablated zone was in the constricted pupillary zone, causing a multifocal area with a power difference of $20.0 \mathrm{D}$. Based on the topographical findings, a soft contact lens would not restore visual acuity. A rigid gas-permeable (RGP) contact lens was chosen to rehabilitate the BCVA. In standard RGP fitting, the most comfortable fit occurs when the lens rests in a slightly superior position and receives support from the upper lid. The apex of this patient's right eye was much steeper than that in most normal keratoconus eyes and had a smaller steep zone; the periphery of the cornea was almost spherical, which is not the case in keratoconus eyes. (Figure 9-2) The procedure used to fit the RGP lens was essentially pragmatic. Various types of lens designs for keratoconus eyes were tried, ranging from small standard lenses to lenses with a steeper central curve with aspheric geometry and with 
peripheral, continuous, contralateral offset curves that simulate a true conocoid surface. It was difficult to achieve equal pressure distribution on the corneal apex in combination with excessive movement of the lens. Therefore, inadequate centration was a problem.

Finally, a multicurve trial lens with a base curve radius of $7.80 \mathrm{~mm}$ was well tolerated.

Table 9-2.

Contact lens specifications for the right eye

\begin{tabular}{ll} 
Material & Boston XO (Polymer Technology Corporation) \\
Permeability (gas to gas method) & $140\left(\times 1011\left(\mathrm{~cm}^{2} / \mathrm{scc}\right) \mathrm{ml}(\mathrm{O} \times \mathrm{mm} \mathrm{Hg})\left(235^{\prime \prime} \mathrm{C}\right.\right.$ \\
Refractive index & 1,415 \\
Base curve (mm) & 7.80 \\
Prescription (spherical) & -1.50 \\
Diameter (mm) & 9.30 \\
Front optical zone diameter (mm) & 7.40 \\
Thickness (mm) & 0.19 \\
Peripheral curves (mm) & $8.30 / 9.30 / 12.50$ \\
Edge design & negative wedge bearing zone \\
\hline
\end{tabular}

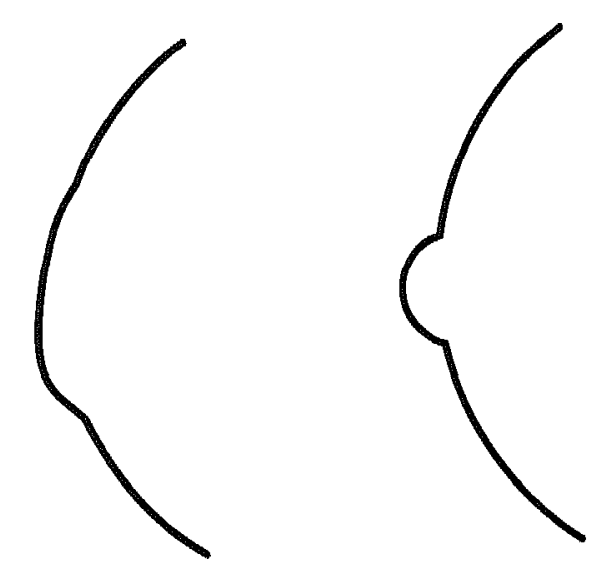

Figure 9-2. The intersection of a keratoconus eye (left) and an iatrogenic keratectasia eye (right). The distinction in the place and form of the corneal apex between keratoconus and keratectasia suggests the differences in contact lens fitting between keratoconus and keratectasia eyes 
Chapter 9

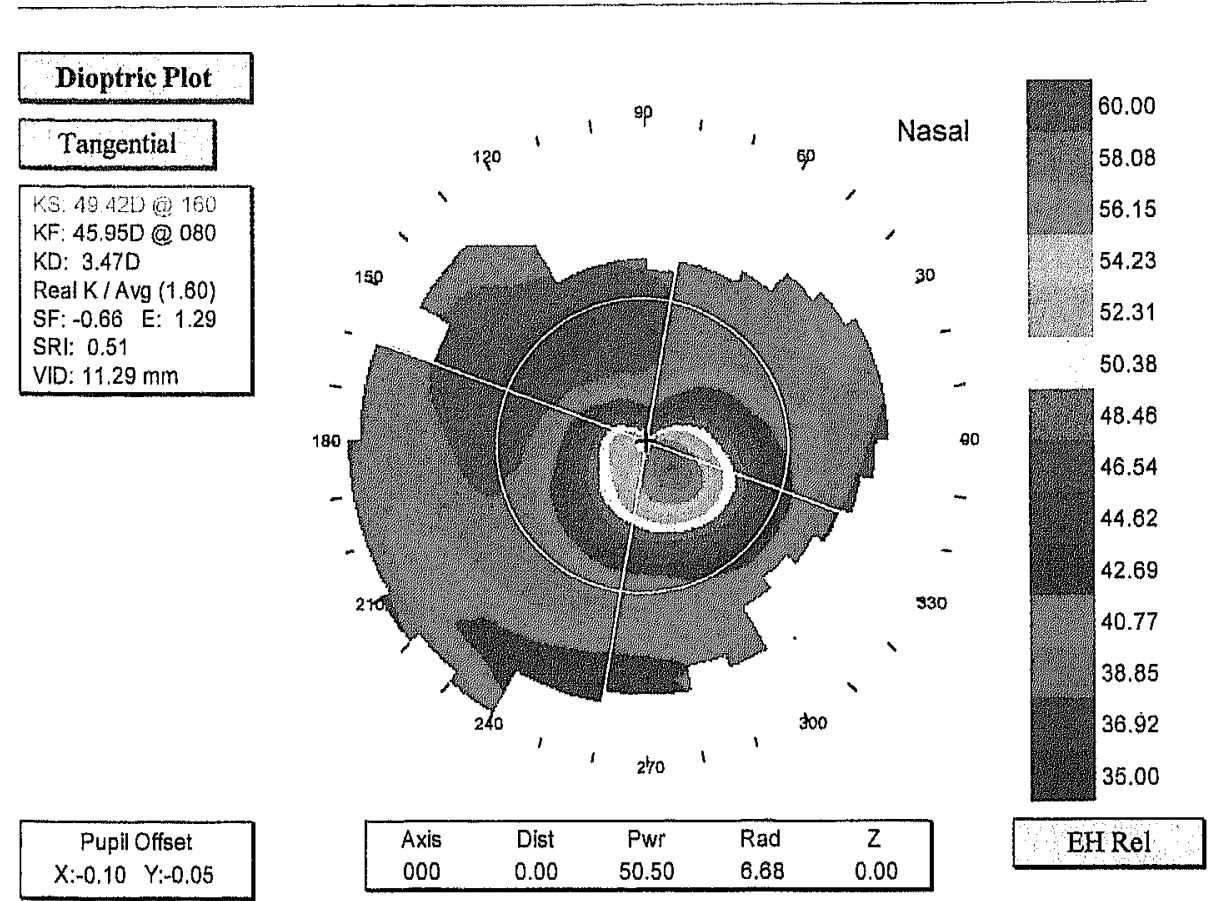

Figure 9-1, Tangential topographical map of the right eye.

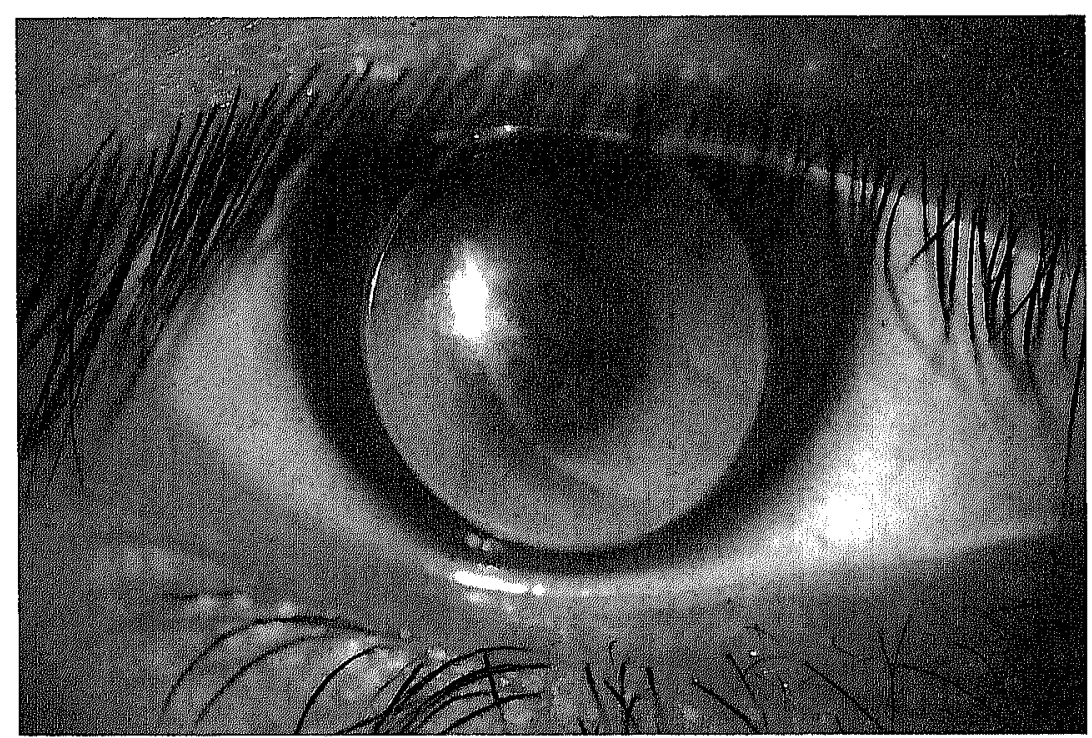

Figure 9-3. Fluorescein pattern in the right eye with the contact lens in situ. 
The fluorescein pattern showed a flattening indentation of the corneal apex (Figure 9-3). The diameter of the contact lens was chosen so the upper edge of the lens would ride under the upper lid to facilitate lens movement, enhance tear exchange, and increase comfort. The custom-made lens had a diameter of 9.3 mm with a negative wedge-bearing zone at the edge of the lens to keep the lens edge under the upper lid during eye movements and blinking (Figure 9-4). During the dispensing visit, the patient was instructed in lens handling and Allergan "contact lens care solutions were dispensed. Follow-up examinations were performed 2, 4 and 8 weeks after fitting.

At each follow-up visit, visual acuity was determined and manifest refraction with the lens in place was performed. Slitlamp examination was performed with and without fluorescein. The lens was removed and another slitlamp evaluation, topographical analysis, and pachymetry were performed.

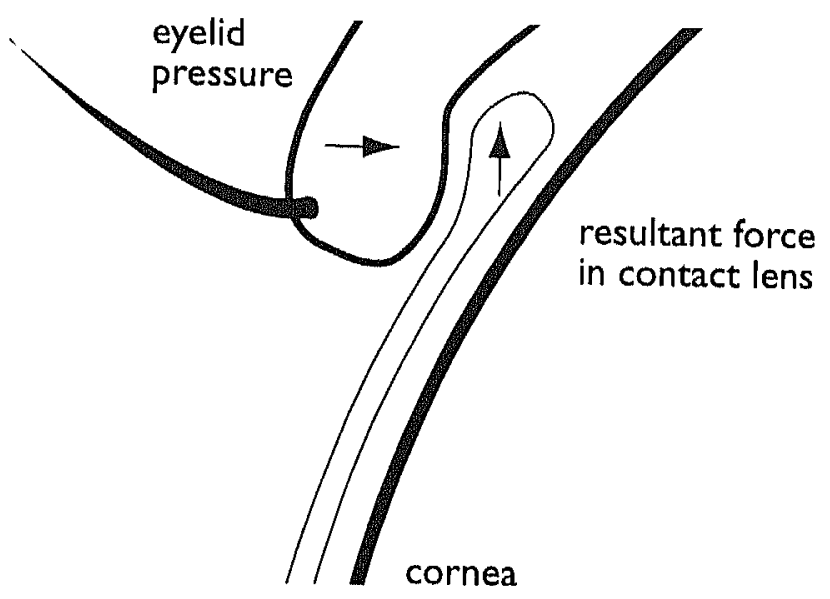

Figure 9-4. The pressure of the eyelid against the wedge form of the lens edge results in an upward force of the contact lens. The fit of the lens is so manipulated that it looks as if the edge of the lens sticks to the upper lid in all eye movements. 


\section{Chapter 9}

During the follow-up after lens fitting, the visual acuity in the right eye with the contact lens was 20/25, which was almost the same as the preoperative value of 20/20. The contact lens specifications are shown in Table 9-2. A change in corneal curvature does not affect visual acuity with the contact lens. Because of the filling up characteristics of the tear film, only the tear lens beneath the contact lens will change in shape. Lens movement is possibly changed with a change in curvature of the central part of the cornea, but the lens alignment was also based on the peripheral negative-bearing zone at the edge of the lens design to keep the lens edge under the upper lid. Choosing a flat base curve and progressive eccentricity to the periphery of the lens (Table 9-2) prevented lens binding. The lens bearing on the central steep area of the cornea had a diameter of $1.5 \mathrm{~mm}$ and showed no signs of epithelial damage after 6 to 8 hours of contact lens wear when the patient was examined. At the 4 and 8 weeks visits, the patient had a daily contact lens wearing time of 12 hours and the contact lens was tolerated well.

\section{DISCUSSION}

The etiology of iatrogenic keratectasia is not known, other than to state that intraocular pressure causes forward bowing and thinning of a structurally compromised cornea. The development of keratectasia after refractive surgery may be higher in cases of forme fruste and keratoconus. ${ }^{(3)} \mathrm{A}$ thin cornea or an excessively thin residual stromal bed following refractive surgery are also risk factors for the development of iatrogenic keratectasia. ${ }^{(8,9)}$ In our patient, the preoperative corneal thickness was $450.00 \mu \mathrm{m}$, the theoretical flap thickness was $160.00 \mu \mathrm{m}$, and the ablation was $77.75 \mu \mathrm{m}$, resulting in a residual posterior corneal thickness of $212.00 \mu \mathrm{m}$, which is thinner than literature advises. We agree with Wang and coauthors ${ }^{(9)}$ that the preoperative cornea pachymetry of this patient revealed an excessively thin residual stromal bed in which the risk of ectasia may be increased. Especially in this low myopic refraction, photorefractive keratectomy (PRK) would have been a better solution to fulfill the patient's desire to be less dependent on spectacles.

Kremer and coauthors ${ }^{(10)}$ report 6 patients with topographic changes, suggestive of keratoconus without notable thinning, followed for more than 3 years after PRK. In most patients, the UCVA improved. Pachymetry of the remaining stromal bed in these patients after PRK ablation was more than $250.00 \mu \mathrm{m}$.

Joo and Kim ${ }^{(7)}$ present a case in which a contact lens was fitted, but they do not describe the contact lens parameters, visual acuity, or daily wearing time of the contact lens. As far as we know, no paper has described a fitting technique in patients with keratectasia following refractive surgery. 
In keratoconus eyes, most apices are located in the inferotemporal quadrant. ${ }^{(11)}$ In this patient, there was apex and corneal thinning in the center, the part of the cornea where most stromal tissue was ablated. Most contact lens designs for keratoconus patients exhibit an apical clearance fluorescein pattern (12) or a 3-point touch. ${ }^{(13)}$ We tried to achieve a contact lens fit with apical clearance in this patient, but the central apex was so steep and small that in all trials with keratoconus lenses, trapped air-bubble formation below the apex disturbed the visual acuity. A 3-point touch technique is not possible because the periphery around the apex was almost spherical in contrast to that in keratoconus eyes.

In this patient, there was an indentation/flattening of the keratectasia, caused by the RGP contact lens. The topographical map of the left eye suggest that we should monitor this eye as closely as the right eye during the following years. Deep anterior lamellar keratoplasty ${ }^{(14)}$ can probably be avoided by careful monitoring of the contact lens fit in this patient. 


\section{Chapter 9}

\section{REFERENCES}

1. Wellish KL, Glasgow BJ, Beltram F, Maloney RK. Corneal ectasia as a complication of repeated keratotomy surgery. J Refract Corneal Surg 1994; $10: 360-364$

2. Speicher L, Göttinger W. Progressive Keratektasie nach Laser-in-situ Keratomileusis (LASIK). Klin Monatsbl Augenheilkun 1998; $213: 247-251$

3. Seiler T, Quurke AW. Iatrogenic keratectasia after LASIK in a case of forme fruste keratoconus. J Cataract Refrct Surg 1998; 24 : 1007-1009

4. Koch DD. The riddle of iatrogenic keratectasia. J Cataract Refract Surg 1999; 25 : 453 454

5. McLeod SD, Kisla TA, Caro NC, McMahon T T. Katrogenic Keratoconus: Corneal Ectasia Following Laser in Situ Keratomileusis for Myopia. Arch Ophthalmol 2000; 118 :282-284

6. Geggel HS, Talley AR Delayed onset keratectasia following laser in situ keratomileusis. J Cataract Refract Surg 1999; $25: 582-586$

7. Joo Choun-Ki, Kim Tae-Gyung. Corneal ectasia detected after laser in situ keratomileusis for correction of less than -12 diopters of myopia. J Cataract Refract Surg 2000;26:292295

8. Probst LE, Machat JJ. Mathematics of laser in situ keratomileusis for high myopia. J Cataract Refract Surg 1998; $24: 190-195$

9. Wang Z, Chen J, Yang B. Posterior Corneal Surface Topographic Changes after Laser in Situ Keratomileusis are related to Residual Corneal Bed Thickness. Ophthalmol 1999; 106 :406-409

10. Kremer I, Shochot Y, Kaplan A, Blumenthal M. Three year results of photoastigmatic refractive keratectomy for mild and atypical keratoconus. J Cataract Refract Surg 1998; 24 :1581-1588

11. Demirbas NH, Pflugfelder SC. Topographic pattern and apex location of keratoconus on elevation topography maps. Cornea 1998; $17: 476-484$

12. Edrington TB, Szczotka LB, Barr JT et al. Rigid contact lens fitting relationships in keratoconus. Collaborative Longitudinal Evaluation of Keratoconus (CLEC) Study Group. Optom Vis Sci 1999; $76: 692-699$

13. Edrington TB, Barr JT, Zadnik K et al, Standardized rigid contact lens fitting protocol for keratoconus. Optom Vis Sci 1996; $73: 369-375$

14. Melles GR, Lander F, Rietveld FJ, Remeijer L, Beekhuis WH, Binder PS. A new surgical technique for deep stromal, anterior lamellar keratoplasty. Br J Ophthalmol 1999; 83 ;327333 


\section{Rigid gas-permeable contact lens fitting in laser in situ keratomileusis patients for the correction of multifocal corneas}

Fred A.G.J. Eggink ${ }^{(1,2)}$

W. Houdijn Beekhuis, MD (2)

Rudy M.M.A. Nuijts, MD, Ph.D. (1)

1. Academic Hospital Maastricht

2. The Eye Hospital Rotterdam

Graefe's Archive for Clinical and Experimental Ophthalmology, 2001; 239:361-6.

Supported in part by a grant of the Department of Ophthalmology, University Hospital Maastricht. 


\section{ABSTRACT}

\section{Background:}

Laser in situ keratomileusis (LASIK) has recently become the most commonly performed refractive surgery procedure. Results are promising in correcting low to moderate myopia. Most complications occur during the surgeons' learning curve. One of the complications is a decentration of the ablated area that causes monocular diplopia and a nocturnal halo phenomenon due to a multifocality of the corneal surface overlying the entrance pupil. The corneal shape is significantly altered after LASIK. We evaluate the efficacy of rigid gas-permeable contact lens designs and fitting techniques used in eight eyes with multifocal LASIK ablations to correct haloes and impaired night vision complaints. Methods:

We used large-diameter tetra-curved rigid gas-permeable (RGP) contact lenses for visual recovery in eight eyes of seven LASIK patients. We used the power on the transition zone of the corneal topographic map, $0.2 \mathrm{~mm}$ outside the ablated refractive area, for selection of the back optic zone radius of the RGP contact lenses. Procedures for lens fitting are described. Visual acuity (high-contrast logarithm of the minimum angle of resolution, LogMAR) was measured before- and 6 months after contact lens fitting.

Results:

Large-diameter tetra-curve RGP lenses with a mean diameter of $11.85 \mathrm{~mm}$ were successfully used in LASIK patients with multifocal corneas. Mean best spectacle-corrected visual acuity was +0.3 LogMAR (in Snellen equivalent, 20/40) and improved with the contact lenses to +0.08 LogMAR (in Snellen equivalent, 20/25). During the follow-up period of 16.7 months, the average daily wearing time of the lenses was 12.5 hours. Contact lenses with a standard geometry were not useful due to excessive movement and inadequate centration.

\section{Conclusions:}

Contact lenses with large diameters, in combination with selection of the back optic zone radius $0.2 \mathrm{~mm}$ peripheral of the refractive ablation zone, facilitate contact lens fitting to restore best-corrected visual acuity in LASIK patients with multifocal corneas. 


\section{INTRODUCTION}

Laser in situ keratomileusis (LASIK) is a surgical procedure, and like all surgery it is affected by for risks and complications, both during and after operation [14]. Most intra-operative complications arise in the course of a given surgeon's first 300 cases $[5,22]$. One of the complications is a decentration of the ablated zone [17]. When the center of the ablated zone is still in the constricted pupillary zone, most patients will not have a notable distortion of the visual acuity during day time, but when the center of the ablated zone is outside this region the corneal center becomes multifocal and a loss of best spectaclecorrected visual acuity (BSCVA) occurs. A loss of two or more Snellen lines of BSCVA is regarded as a significant loss of vision [11].

Since a reliable topographically guided laser is not yet available, we chose to fit large-diameter tetra-curved RGP contact lenses in such cases to restore the initial visual acuity of these patients. Fitting RGP lenses after refractive surgery is not as straightforward as one might expect. Different types of lens designs have been used, ranging from small standard lenses to lenses with a steeper peripheral curve. Problems with achieving equal pressure distribution on the cornea, excessive movement of the lens, and inadequate centration of the lens have been reported [2]. Some reports of RGP lens fitting techniques after photo refractive keratectomy (PRK) excimer laser treatment have been published [20, 21]. Publications on the fitting of contact lenses in LASIK patients are sparse in the literature [23]. In the past we had fitted RGP lenses in irregular corneas following radial keratotomy (RK) and photo-therapeutic keratectomy (PTK) [6, 7], and we used this experience for fitting contact lenses in LASIK patients.

The purpose of the study was to evaluate the efficacy of the described RGP contact lens design and fitting techniques following LASIK refractive surgery. Selection of the back optic zone radius was according to the videotopographic values in the transition zone, 0.2 millimeter outside the refractive abated area. 


\section{Chapter 10}

\section{MATERIALS AND METHODS}

We fitted contact lenses in eight LASIK eyes; six eyes of five patients with a decentered or overcorrected ablation, one eye with an irregular corneal surface, and one eye with myopisation because of retinal detachment, all in combination with a reduction in BSCVA of two or more Snellen lines. Informed consent was obtained from all patients. Mean visual acuity with glasses and contact lenses was calculated using the high-contrast logarithm of the minimum angle of resolution (LogMAR) chart. First, we describe the fitting technique and present the first case; all cases are summarized in Table 10-1.

\section{Fitting technique}

In the past ten years we have seen several myopic patients with visual acuity problems following refractive surgery. This gave us the opportunity to develop a post-refractive surgery contact lens fitting technique. In unoperated eyes, most contact lens fitting methods use keratometry values in combination with the fluorescein pattern for selection of the back optic zone radius of the initial trial lens. After refractive surgery, the central keratometry values may no longer be representative for the entire corneal surface area. In fact, the radii within the central 3.2- $\mathrm{mm}$ optical zone of a cornea after refractive surgery often show no correlation with the radii in more peripheral areas of the same comea. A good contact lens fit depends on the best possible overall support of the contact lens across the cornea. After refractive surgery, a videotopographic color map provides better insight into the entire postoperative corneal contour than central keratometry. More detailed analysis of the videotopographic map may further facilitate the selection of the back optic zone radius and the entire fitting procedure.

The custom-made lenses, designed by one of us (FE), have a back optic zone diameter of $8.5 \mathrm{~mm}$ bridging the ablated area. The first peripheral curve is $0.5 \mathrm{~mm}$ flatter than the back optic zone radius and has a diameter of $10.5 \mathrm{~mm}$. The second peripheral curve is $1.5 \mathrm{~mm}$ flatter than the back optic zone radius and has an overall diameter of $12.0 \mathrm{~mm}$. The edge radius was $12.5 \mathrm{~mm}$. All transitions were soft blended. In all cases we used a contact lens material with a very high Dk value to avoid conneal edema, such as Boston XO with a Dk of 100 (Polymer Technology Corp, Wilmington MA, USA) or FluoroPerm 151 with a Dk of 151 (Paragon Vision Sciences, Mesa AZ, USA).

In our experience the first trial lens should have midperipheral corneal alignment and central pooling. In all cases we used corneal topography colorcoded maps in the tangential absolute scale (Alcon Eye Map, Alcon Laboratory inc.; software version 5.50) to localize the transition 
Contact lens fitting in multifocal corneas following LASIK

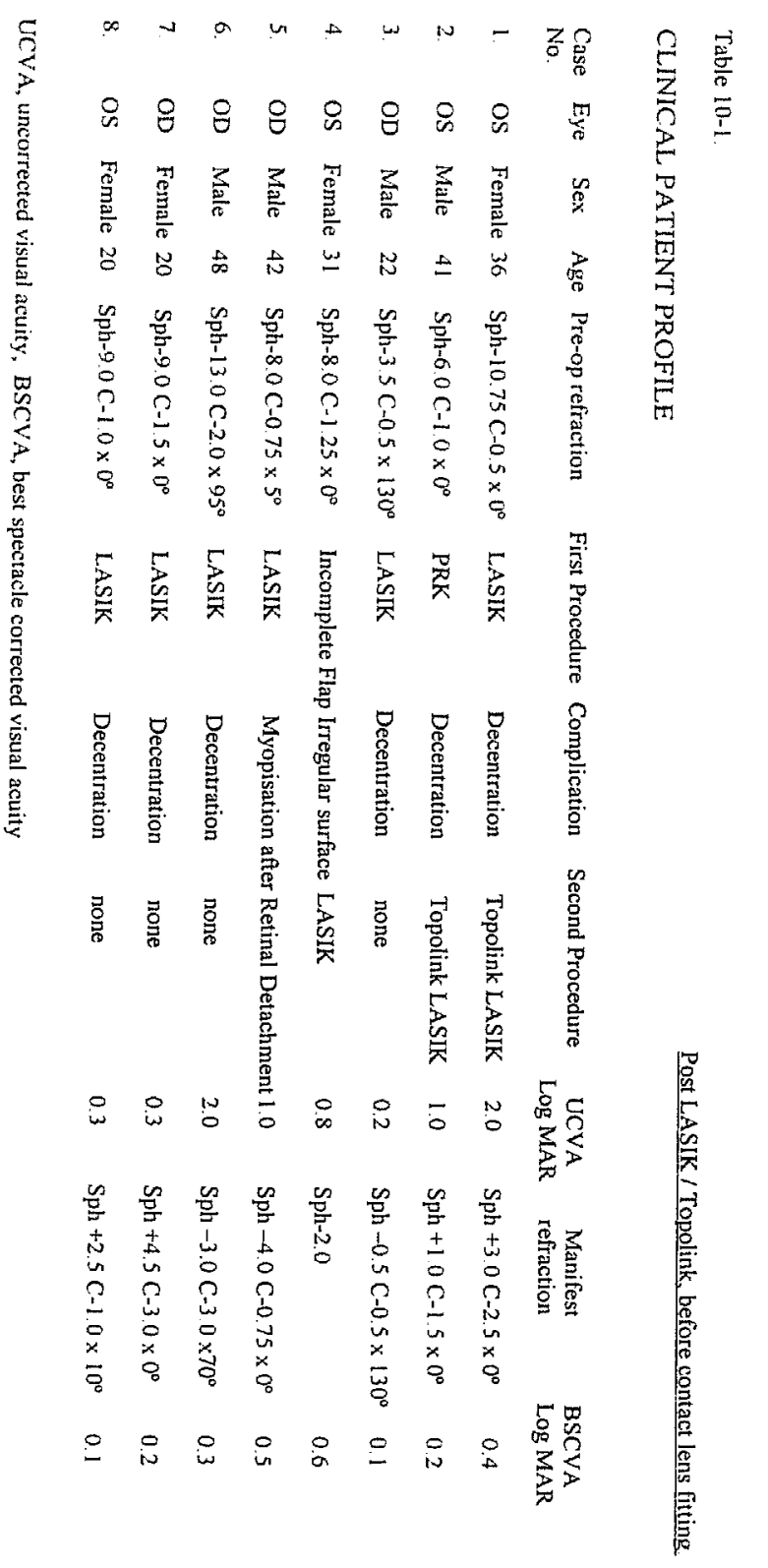


between the refractive ablated zone and the peripheral zone for choosing the back optic zone radius of the first trial lens. We selected the back optic zone radius of the trial-lens to provide a large bearing zone in the region approximately 0.2 millimeter outside the border of the refractive ablation zone. To determine the radius on that spot, we placed the cursor of the topographic instrument on the transition zone $0.2-\mathrm{mm}$ outside the border of the refractive ablation zone. The radius on that spot was identical to the back optic zone radius of our first trial lens.

The contact lens fit showed a fluorescein pattern with fluorescein pooling in the central flat (blue) areas and fluorescein displacement in the midperipheral steep (green) areas. The back optic zone radius is steepened when the fit is too flat with excessive peripheral lift-off. We flattened the back optic zone radius when the lens fit is too steep with air bubbles under the central part or when there was excessive peripheral impingement. The most comfortable RGP fit occurs when the lens rests in a slightly superior position and receives support from the upper lid.

Case 1. A 20 year-old woman had a bilateral LASIK treatment in Bogota, Colombia. The preoperative refraction was OD Sph.-9.0 C-1.5 x $0^{\circ}$, OS Sph. $9.0 \mathrm{C}-1.0 \times 0^{\circ}$ with a VA of $20 / 20$. The bi-lateral LASIK procedures were performed in the same session. Six months postoperatively, the patient came to us and complained of blurred distance and near vision and ghost images since the procedure. The manifest refraction was OD Sph. +4.5 C-3.0 $\times 0^{\circ}$ with an acuity of +0.2 LogMAR (Snellen equivalent 20/32), the uncorrected visual acuity (UCVA) was +0.3 LogMAR (20/40). The manifest refraction OS was Sph. +2.5 C $-1.0 \times 10^{\circ}$ with an acuity of +0.1 LogMAR (20/25), the UCVA was +0.3 LogMAR (20/40). With spectacles, complains of ghost images persisted. To restore the best corrected visual acuity (BCVA) we decided to fit RGP lenses in both eyes; we describe the fitting procedure for the left eye. For this eye the topography showed a well-centered ablated zone (Figure 10-1), somewhat smaller in size than the pupil under normal light conditions, which caused multifocal corneal optics. The flap was well centered. The patient wore soft lenses before the LASIK operation and did not have problems wearing these lenses. The back optic zone radius of the RGP trial lens was based on the greencolored region on the topographic map, indicated by the cursor, $0.2 \mathrm{~mm}$ outside the border of the refractive ablation zone. This corneal area had a refractive power of $38.88 \mathrm{D}(8.68 \mathrm{~mm})$. We found the lens with a base curve of $8.70 \mathrm{~mm}$ and an optical zone diameter of $8.5 \mathrm{~mm}$ to give the best fit (Figure 10-2). Total diameter was $12.0 \mathrm{~mm}$, Sph.-3.0 D peripheral radii of $9.20 / 10.20 / 12.50$. The VA with this lens was +0.1 LogMAR (20/25) and the daily wearing time was 15 hours. 


\section{Contact lens fitting in multifocal corneas following LASIK}

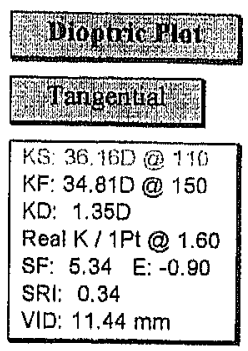

Pupil Offset
$X:-0.13 \quad Y: 0.12$
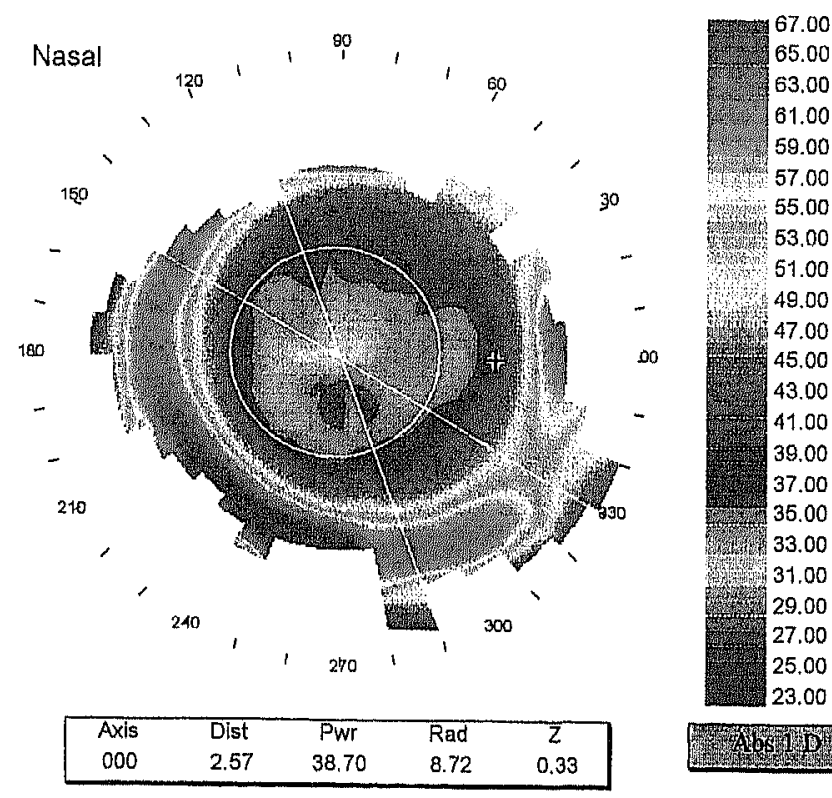

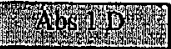

Figure 10-1

Topographic tangential map of the left eye of patient 1 . The determination of the back optic zone radius of the trial lens was based on the green-coloured region indicated by the cursor on the topographic map, $0.2 \mathrm{~mm}$ outside the ablated zone. This corneal area had a power of $38.88 \mathrm{D}(8.70 \mathrm{~mm})$, which was chosen as the back optic zone radius of the trial contact lens, which was the final lens curve

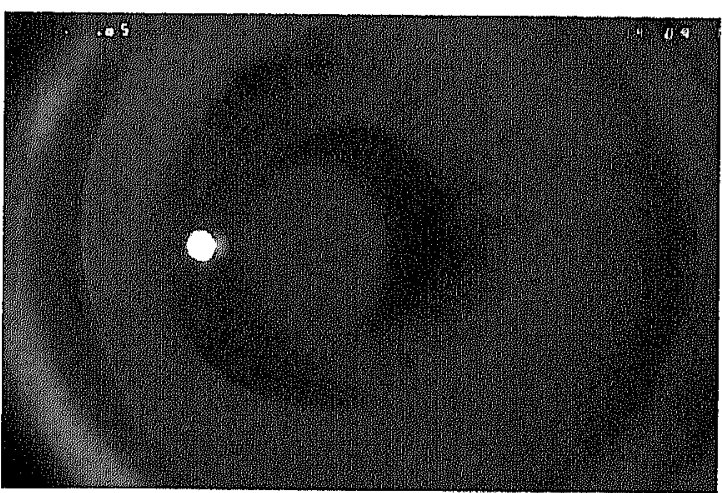

Figure 10-2.

Slit-lamp photography after fluorescein staining of the left eye of case 1 . The fluorescein pattern shows fluorescein pooling at the central ablated area and displacement of fluorescein over the bearing zone. The periphery of the lens shows fluorescein pooling. 


\section{RESULTS}

All patients were contact lens wearers prior to LASIK. Four patients has worn daily soft contact lens, two were previous RGP lens wearers, and one patient had worn both daily soft contact lenses and RGP lenses. Three to six months after the LASIK (mean 4.2, SD 1.4 months), a contact lens was fitted in eight eyes of seven patients, four males and three females (Table 1). All patients were fitted with RGP lenses using the same technique as described in case 1.

Mean UCVA before contact lens fitting was +0.95 (SD 0.7) LogMAR. Mean BSCVA was +0.3 (SD 0.19) LogMAR before contact lens fitting and improved to +0.08 (SD 0.11) LogMAR during contact lens wear. Manifest refractive outcome, 6 months following contact lens wear, did not differ from the data measured before contact lens fitting. Contact lens fitting characteristics, and wearing results are summarized in Table 10-2.

The back optic zone radius of the contact lens ranged from 7.6 to $8.8 \mathrm{~mm}$, the back optic zone diameter of the contact lens ranged from 8.3 to $8.5 \mathrm{~mm}$, and the total lens diameter ranged from 11.5 to $12.0 \mathrm{~mm}$. Mean follow-up after fitting was 16.7 months (range 9 - 28 months). All patients tolerated the contact lens within the first 4 weeks after fitting. All corneas remained clear throughout the study period. Daily wearing time averaged 12.5 hrs (range 10 to 15 hours), and no contact lens binding was observed.

There was no haze noted and all interfaces were without edema at the time of contact lens fitting and 6 months after wearing the contact lenses. The mean contact lens power was $-6.44 \mathrm{D}$ (range -3.5 to $-8.75 \mathrm{D}$ ). A significant positive

Table 10-2

\begin{tabular}{llllllll}
\hline $\begin{array}{l}\text { Case } \\
\text { No }\end{array}$ & $\begin{array}{l}\text { BOZR } \\
\mathrm{mm}\end{array}$ & $\begin{array}{l}\text { BOZD } \\
\mathrm{mm}\end{array}$ & $\begin{array}{l}\text { Total } \\
\text { diameter }\end{array}$ & $\begin{array}{l}\text { Peripheral } \\
\text { curves }(\mathrm{mm})\end{array}$ & $\begin{array}{l}\text { BCLCVA } \\
\text { LogMAR }\end{array}$ & $\begin{array}{l}\text { Wearing } \\
\text { time (hrs) }\end{array}$ & $\begin{array}{l}\text { Follow-up } \\
\text { months }\end{array}$ \\
\hline 1 & 8.70 & 8.5 & 12.0 & $9.20 / 10.20 / 12.50$ & 0.1 & 15 & 27 \\
2 & 8.70 & 8.5 & 11.9 & $9.20 / 10.20 / 12.50$ & 0.0 & 15 & 27 \\
3 & 8.60 & 8.5 & 11.5 & $9.10 / 9.60 / 12.50$ & -0.1 & 14 & 15 \\
4 & 8.70 & 8.5 & 11.8 & $9.60 / 10.60 / 12.50$ & 0.1 & 12 & 15 \\
5 & 7.60 & 8.5 & 11.8 & $8.60 / 9.60 / 12.50$ & 0.0 & 12 & 9 \\
6 & 8.70 & 8.5 & 11.8 & $9.20 / 9.90 / 12.50$ & 0.2 & 10 & 13 \\
7 & 8.20 & 8.5 & 12.0 & $8.70 / 9.70 / 12.50$ & 0.2 & 12 & 9 \\
8 & 8.80 & 8.5 & 12.0 & $9.30 / 10.00 / 12.50$ & 0.2 & 10 & 28
\end{tabular}

BOZR: back optic zone radius, BOZD: back optic zone diameter, BCLCVA best contact lens corrected visual acuity 
tear film was noted at the site of the ablation, contributing to the excessive myopic lens power in all cases. All patients reported excellent visual quality with the RGP lenses, and none of the patients complained of poor centration of the lens or of lens dislodging.

\section{DISCUSSION}

An increasing number of patients are undergoing LASIK refractive surgery. If the comeal apex does not coincide with the center of the patient fixation (the line of sight), the corneal apex will be further displaced from the line of sight after photo-ablation [19]. A patient who experiences a decentration of the ablated area, will see through a multifocal central cornea which may increase glare, induce astigmatism, produce monocular diplopia, reduce contrast sensitivity, and degrade visual acuity [18]. Surgical management of anterior corneal irregularities following excimer laser surgery is difficult, and papers describing treatment of eccentric ablation patterns are sparse [1]. Most published reports concern retreatment of decentered PRK patients using masking techniques or additional ablations [10]; results were generally unsatisfactory. Knorz and Jendritza [13], and Wiesinger-Jendritza et al. [25] describe surgical management of corneal irregularities after LASIK treatments using a topographically guided laser. The results of topographically guided LASIK are promising but contact lenses might be of help until the efficacy of this treatment provides optimal visual performance.

To correct irregular corneal astigmatism following corneal surgery, some authors routinely recommend the use of a piggyback system or Hybride lenses [24]. Slit lamp examination and videotopography showed that peripheral of the LASIK ablation transition zone the cornea still had the same dioptric value as before the operation. In our experience, using central keratometry values for selection of the RGP contact lens back optic zone radius following LASIK always resulted in a too flat fit, causing excessive peripheral lift-off. We therefore hypothesized that the bearing of the contact lens might be improved if the dioptric value on the transition zone, $0.2 \mathrm{~mm}$ peripheral of the refractive ablation zone, were used for selection of the back optic zone radius. Hence, the best possible contact lens bearing at the region approximately $0.2 \mathrm{~mm}$ outside the border of the ablation zone may be expected to give a maximum of comfort in contact lens wearing. Schipper et al. [20] used the preoperative lens designs as a starting point for determining the lens parameters.

In virgin corneas, the central radius is used for selection of the contact lens back optic zone radius, so that the lens power equals the spectacle correction calculated back to the corneal plane. With our technique for lens fitting after LASIK, the back optic zone radius may not have any correlation with the central radius of the operated cornea, i.e. the effective corneal power. 
As a result, the vault between the contact lens and the central cornea, i.e. the tear lens, as demonstrated by the fluorescein pattern, induces a large shift in refractive error.

The most comfortable lens fit was obtained when the lens had a slightly superior position and received support from the upper lid, with good movement and a relatively flat fluorescein pattern. During primary gaze, upward gaze and between blinks, the upper edge of the lens was retained under the upper lid. The bottom edge of the lens should be above the lower lid, but the edge of the optical zone below the inferior pupillary margin, under primary gaze circumstances. Compared to contact lens fitting in virgin corneas, the lens edge was elevated to increase the tear meniscus. This was acceptable because the upper lid has already passed over the lens edge. This concept of lens performance, as if the corneal lens was attached to the upper lid during blinking, may facilitate the tear flow underneath the lens during blinking and eye movements. Lim et al. [16] found mild to moderate lens instability and decentration with RGP lenses in PRK patients. The total diameter of the lenses they used was $9.24 \mathrm{~mm}$. Lee et al. [15] suggested a diameter of $9.5 \mathrm{~mm}$, again significantly smaller than the lenses we used. With larger lens diameters we achieved good centration of the lenses and excellent stability on the cornea. Asymmetric contact zones between cornea and contact lens will always lead to decentration of the contact lens. Centration of these large-diameter lenses is helped by the natural difference in curvature between cornea and sclera. Movement and tear exchange is secured by sufficient flattening of the peripheral edge lift. We use large-diameter contact lenses following various types of corneal (refractive) surgery, including radial keratotomy [6], corneal transplantation [3, 9], phototherapeutic keratectomy [7] and LASIK [8].

Contact lenses with reverse geometry [4] will center on the decentered flat zone and will be decentered to the line of sight, which duplicate the complexity of the optical performance. Manufacturing of contact lenses with reverse geometry requires special lathe-cut machinery, not available in most contact lens laboratories, to make the geometry aplanatic. Lenses with reverse geometry will have a greater tendency towards lens binding than the lenses described in the present paper. Contact lens fitting after LASIK caused no complications in all reported cases with the described lens design.

In virgin eyes we use a sphero-aspheric or bi-aspheric design such as the Boston Envision $\otimes$ lens (Polymer Technology Corporation, Wilmington ,MA USA) or the Bausch \& Lomb Quantum lens $\otimes$ (Bausch \& Lomb, Rochester, NY USA). In these lens designs the diameter can be changed without changing the fitting characteristics. However, in post-LASIK cases we want to enlarge the optical zone or overall diameter as well as creating a steeper fit. With the tetracurve lenses used, the size of the optical zone, peripheral curves, and total diameter can be modified individually, which provides more possibilities for a 
successful fit. These fitting techniques give the opportunity to turn a potentially difficult contact lens fitting into a routine procedure.

Topographical maps and manifest refractive outcome from the eyes under study did not change during contact lens wear. We also fitted RGP contact lenses in patients following PRK. Some of these patients developed a manifest refractive change during lens wear which may have been due to epithelial hyperplasia, because the change was still present 4 weeks after patients discontinued contact lens wear.

In hyperopic patients however, we have had more difficulties in fitting contact lenses following LASIK treatment. In these patients, the center of the cornea is still untreated, and around the corneal peak there is an ablated area that forms a gully drain in which tears accumulate, making it likely that the corneal apex is deprived of sufficient tears for normal contact lens wear.

RGP contact lens fitting in patients with decentered ablation zones offers advantages over soft lenses: the RGP lenses correct irregular astigmatism and most other cornea-related optical aberrations, vault over the centrally flattened cornea, and provide better and stable visual acuity and improved visual function. In the patients under study, it was possible to achieve the same BCVA with RGP contact lenses LASIK as before the LASIK operation, independent of the amount of multifocal corneal optics or decentration of the ablated area. Patient satisfaction may have been higher when all patients achieved full wearing during waking hours.

Corneal wound healing following LASIK appears to vary. Animal studies showed continuation of wound healing even 9 months after operation [12]. During the first year following surgery, flap displacement or microwrinkles may be a postoperative complication due to manipulation of the contact lens. Special attention to instruction of the patient is recommended; use of a suction cup should be discouraged.

In summary, fitting of RGP lenses in LASIK patients with optical distortions is effective and results in a recovery of visual acuity to preoperative values.

\section{REFERENCES}

1. Alkara N, Genth U, Seiler T. (1999) Diametral ablation, a technique to manage decentered photorefractive keratectomy for myopia. J Refrect Surg 15:436-40.

2. Astin C. (1986) Considerations in fitting contact lenses to patients who have undergone radial keratotomy. Trans Br Contact Lens Assoc Conf. 2-7.

3. Beekhuis WH, van Rij G, Eggink FAGJ, Vreugdenhil W, Schoevaart CE. (1991) Contact Lenses Following Keratoplasty. CLAO J 17: 27-29.

4. Bergmanson J.P.G., Leach N.E., Jackson A. (2000) A novel rigid gas permeable contact lens design for post refractive surgery cornea. Invest Ophthalmol Vis Sci. 47 suppl: 873

5. Blanckaert J, Sallet G. (1998) Lasik learning curve: clinical study of 300 myopic eyes. 
Bull Soc Belge Ophthalmol. 268: 7-12

6. Eggink FAGJ, Beekhuis WH. (1989) Contact lens fitting following radial keratotomy and other relaxing incisions. Contactologia. 11: 164-168.

7. Eggink FA, Beekhuis WH. (1995) Granular dystrophy of the cornea. Contact lens fitting after phototherapeutic keratectomy. Cornea 14: 217-222.

8. Eggink FAGJ, Beekhuis WH. (2001) Contact lens fitting in a patient with keratectasia following LASIK. J Cataract Refract Surg Accepted for publication.

9. Eggink FAGJ, Vreugdenhil W, Beekhuis WH. (1994) Therapeutische Kontaktlinsen nach Keratoplastiek die Kontaktlinse 28; 5-10.

10. Eggink FAGJ, Beekhuis WH, Trokel SL, den Boon JM. (1996) Enlargement of the photorefractive keratectomy optical zone. J Cataract Refract Surg 22:1159-64.

11. Hersh PS, Brint SF, Maloney RK, Durrie DS, Gordon M, Michelson MA, Thompson VM, Berkeley RB, Schein OD, Steinert RF. (1998) Photorefractive keratectomy versus laser in situ keratomileusis for moderate to high myopia. Ophthalmology 105:1512-23.

12. Kato T, Nakayasu K, Hosoda Y, Watanabe Y, Kanai A. (1999) Corneal wound healing following laser in situ keratomileusis (LASIK): a histopathological study in rabits. $\mathrm{Br}$ J Ophthalmol 83:1302-5

13. Knorz MC, Jendritza B. (2000) Topographically-guided laser in situ keratomileusis to treat corneal irregularities. Ophthalmology 107:1138-43

14. Knorz MC, Jendritza B, Liermann A, Hugger P, Liesenhoff H. (1998) LASIK for myopia correction. 2 year follow-up. Ophthalmologe. 95: 494-498.

15. Lee AM, Kastl PR. (1998) Rigid gas permeable contact lens fitting after radial keratotomy. CLAO J 24: 33-35.

16. Lim L, Siow KL, Chong Chong JS, Tan DTH. (1999) Contact lens wear after photorefractive keratectomy: comparising between rigid gas permeable and soft contact lenses. CLAO J 25: 222-227.

17. Mulhern MG, Foley-Nolan A, O’Keefe M, Condon PI.(1997) Topographical analysis of ablation centration after excimer laser photorefractive keratectomy and laser in situ keratomileusis for high myopia. J. Cataract Refract Surg. 23: 488-494.

18. Oshika T, Klyce SD. (1998) Corneal Topography in LASIK. Seminars in Ophth 13: 64-70.

19. Patel S, Marshall J, Fitzke FW, Gartry DS. (1994) The shape of the corneal apical zone after excimer photorefractive keratectomy. Acta Ophthal 72: 588-596

20. Schipper I, Businger U, Pfarrer R. (1995) Fitting contact lenses after excimer laser photorefractive keratectomy for myopia. CLAO J. 21: 281-284.

21. Shovlin JP, (1992) The anterior segment: a comparison between patients wearing contact lenses following radial keratotomy and myopic photorefractive keratectomy with excimer laser. ICLC 19: 141-142,

22. Stulting RD, Carr JD, Thompson KP, Waring GO. (1999) Complications of Laser In Situ keratomileusis for the Correction of Myopia. Ophthalmology 106: 13-20.

23. Szczotka LB, Aronsky M. (1998) Contact lenses after lasik. J Am Optom Assoc. 69: 775-784.

24. Vreugdenhil W, Rijneveld WJ, Eggink FAGJ. (1994) Fitting therapeutic SoftPerm contact lenses in the event of corneal pathology with highly irregular astigmatism. The $\mathrm{J}$ of the $\mathrm{Br}$ contact lens ass 17:59-61.

25. Wiesinger-Jendritza B, Knorz MC, Hugger P, Liermann (1998) A. Laser in situ keratomileusis assisted by corneal topography. J Cataract Refract Surg 24:166-74. 
GENERAL DISCUSSION 


\section{1 - 1 GENERAL DISCUSSION}

In this thesis, rigid contact lens fitting techniques are described following different types of corneal surgery, such as penetrating keratoplasty, lamellar keratoplasty, phototherapeutic keratectomy (PTK), and in patients with complications after laser in situ keratomileusis (LASIK). Our studies enabled us to determine the efficacy of the various fitting techniques, and to define at what postoperative time interval, what type of complication after corneal surgery can be effectively managed with rigid contact lens fitting.

There were two major indications for contact lens fitting after all types of corneal surgery. The first was comeal irregularity or deformation, i.e. an imperfect corneal contour induced by the surgery: a monocular problem. The second was anisometropia, i.e. a difference in refractive power between both eyes, most often occurring as an expected side effect of surgery that could not be avoided: a binocular problem.

After penetrating or lamellar keratoplasty, rigid gas permeable contact lens fitting was performed in $20 \%$ of eyes for both indications, i.e. corneal irregularity and anisometropia were present in the same eye. The actual number of patients, in whom postkeratoplasty contact lens fitting is indicated to obtain a useful visual acuity may be much higher. A large group of patients, especially elderly patients, refuse contact lens fitting after surgery. Since these patients never obtain a useful visual acuity in daily life, a relatively large number of corneal transplants may be considered relative failures. If so, it may be recommended to determine if a trial contact lens is tolerated by a patient prior to the surgery. If a patient is unable or unwilling to wear a contact lens, this should be considered as a relative contra-indication for performing a penetrating or lamellar keratoplasty.

In our studies contact lens fitting was started within the months following the surgery, using large diameter rigid gas permeable contact lenses, which have the advantage of good centration and excellent stability on the cornea. Our technique of fitting high Dk contact lenses while the sutures are in place, using the elevated wound edges of the corneal transplant as contact lens bearing zone, may be a good option for full optical, early rehabilitation in patients with irregular astigmatism and anisometropia (Chapter 3 and 4). The contact lens fitting chart, Table 11-1 reviews the fitting technique in post-keratoplasty patients. LASIK is currently being investigated for treatment of postkeratoplasty anisometropia or astigmatism at later time intervals, after all sutures have been removed. ${ }^{1,2}$

After phototherapeutic keratectomy (PTK) for the treatment of superficial anterior basement membrane dystrophies, the smoothness of the anterior corneal 
surface after re-epithelialization is the major factor defining best spectacle corrected visual acuity (BSCVA). In our study, rigid gas permeable contact lens fitting was performed to improve the best corrected visual acuity (BCVA) (Chapter 5 and 6), but only one line of BCVA was gained in four out of ten eyes. We found that six months after PTK, a final best spectacle corrected visual acuity is reached after PTK for the treatment of superficial anterior basement membrane dystrophy's. Therefore, in our series, a subnormal BSCVA after PTK may have resulted from other factors than astigmatism, and contact lens fitting may have a limited role in the management of post PTK cases.

In the early days of photorefractive keratectomy (PRK), excimer lasers had apertures of 5.0 millimeter (Chapter 7). The ablated optical zone diameter was small relative to a normal pupil size. As a result, some patients complained of haloes and impaired night vision. Although RGP contact lens fitting may be effective to manage these visual side effects, a more convenient treatment may be enlargement of the optical zone diameter with a broad beam excimer laser. Enlargement of the optical zone diameter may also be performed in selected PRK patients with decentered ablations.

Following corneal refractive surgery, contact lenses fitting may be difficult due to significant alterations in comeal architecture and function. ${ }^{3}$ Rigid gas permeable contact lens fitting after LASIK surgery, to improve BCVA is rarely performed. Intra- and postoperative complications, including residual refractive errors, are reported in about $5 \%$ of the procedures. ${ }^{4}$ Up till now, the surgical management of anterior corneal irregularities following excimer laser surgery is difficult and generally unsatisfactory, ${ }^{5,6}$ Rigid gas permeable contact lens fitting might be the treatment of choice in these patients until the efficacy of laser treatment modalities is further improved.

The development of keratectasia after LASIK, has been reported in 36 eyes. ${ }^{7.8}$ Rigid gas permeable contact lens fitting has been reported in six keratectasia patients, but the fitting technique has not been described (Chapter $8)^{9}$

In our experience, in a patient with corneal keratectasia after LASIK, a contact lens design for keratoconus patients can not be used because fitting these lenses exhibit an apical clearance fluorescein pattern, or a three point touch. ${ }^{10,11}$ The apex and corneal thinning in the keratectasia is located in the center, the part of the cornea where most stromal tissue was ablated, whereas in keratoconus eyes corneal mid-periphery is a-spherical and the majority of apices are located in the inferotemporal quadrant. ${ }^{12}$ Contact lenses designed for keratoconus eyes give air-bubbles around the apex of the keratectasia with distortion of visual acuity. Therefore a normal lens may be used with a negative wedge bearing zone, and of an very high Dk contact lens material with standard diameter of $9.3 \mathrm{~mm}$. The back optic zone radius of the lens is chosen by trial and 


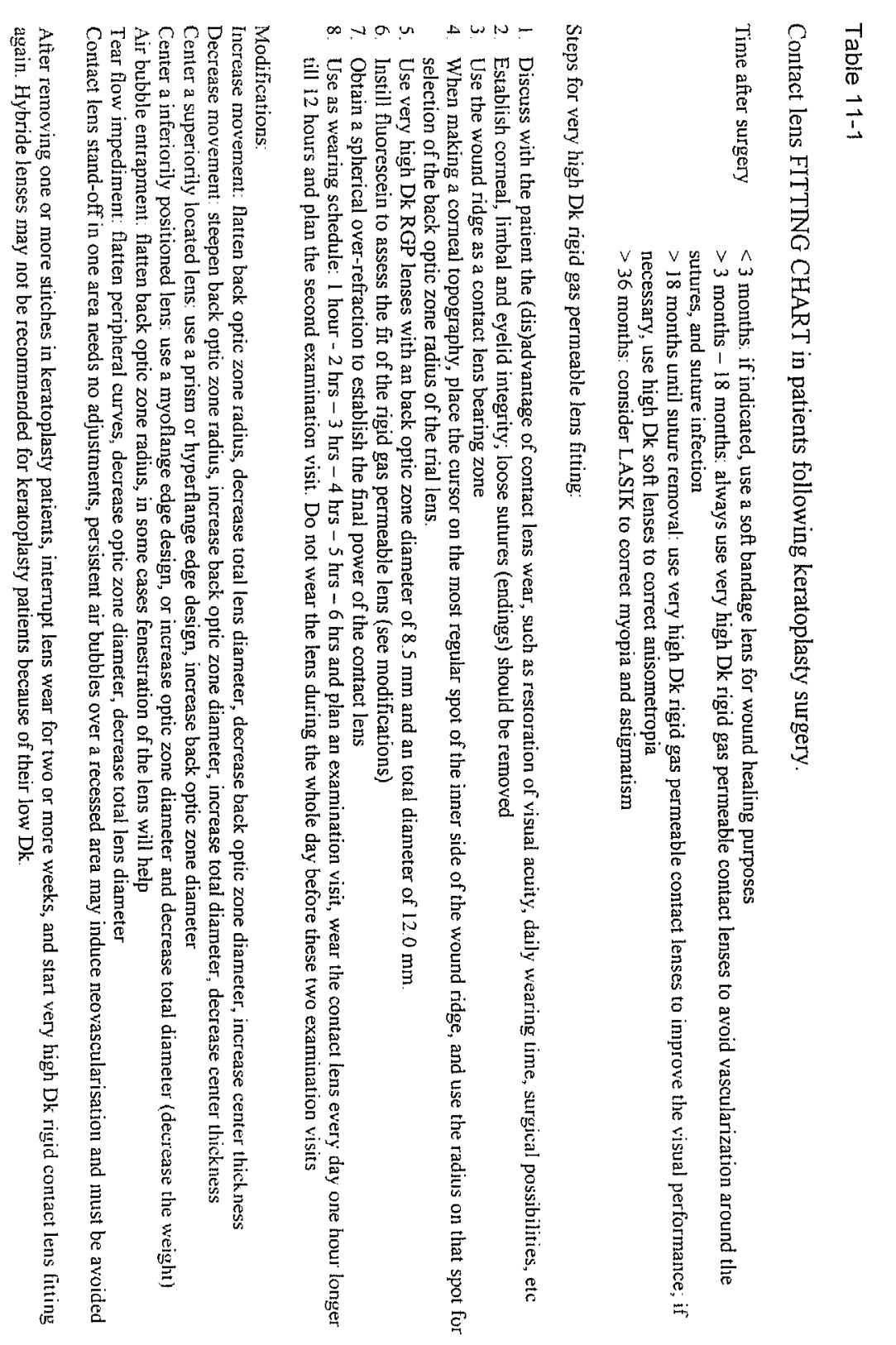




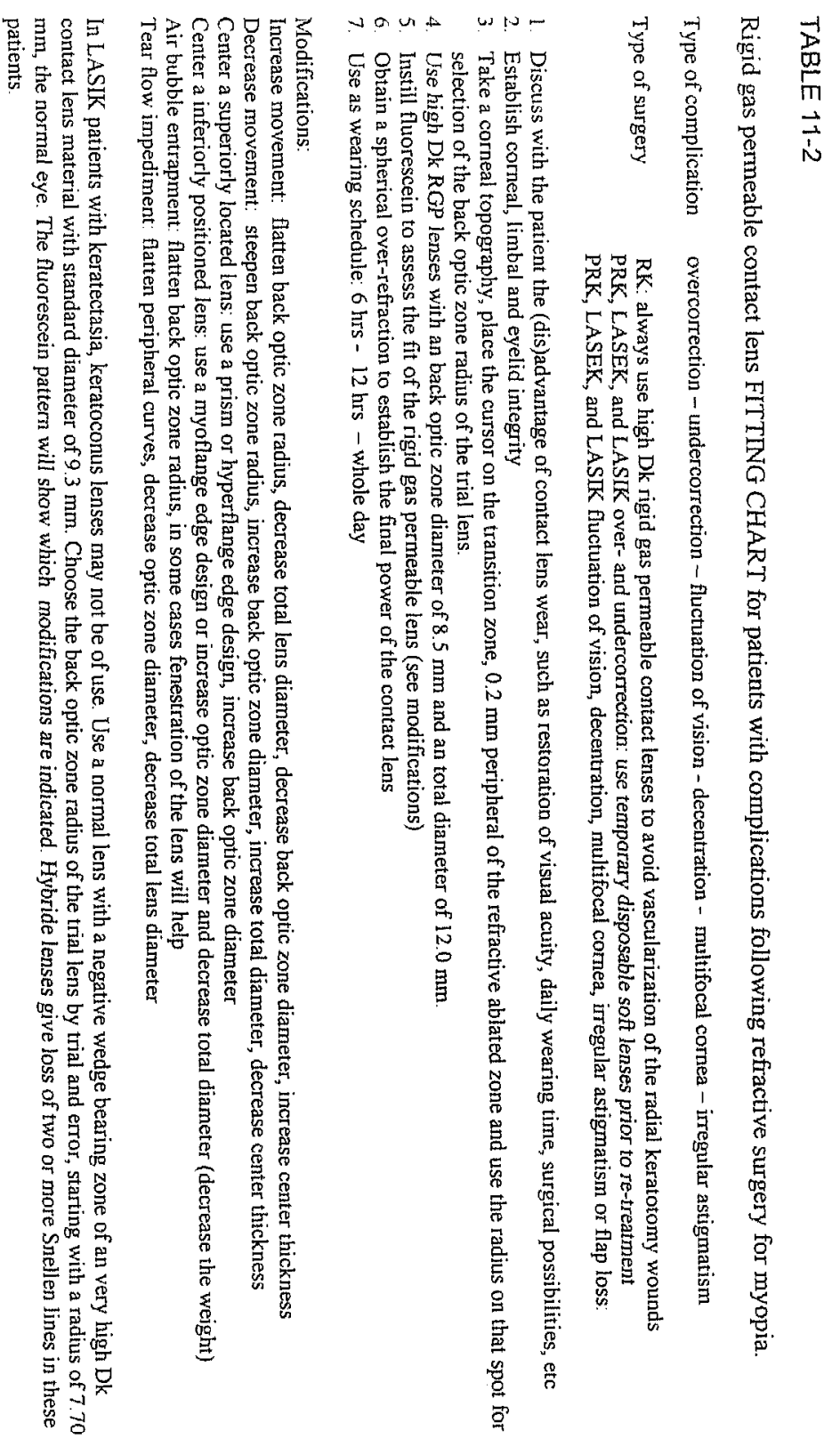


error, starting with a radius of the normal eye, ie $7.70 \mathrm{~mm}$. The fluorescein pattern showed us which modifications we had to make. Hybride lenses showed a loss of two or more Snellen lines in our patient.

The use of newer imaging modalities, such as confocal microscopy and high-frequency ultrasound, may help to evaluate corneal changes after LASIK in vivo, giving better insight in post-operative topographical changes. ${ }^{13}$

To our knowledge, flap loss after LASIK has not been reported. Flap loss related complications rarely lead to a permanent decrease in best spectacle corrected visual acuity with appropriate treatment, and therefore contact lens fitting following flap loss may be rarely indicated (Chapter 9).

Decentration, multifocality of the cornea, over- and undercorrection may be managed with rigid gas permeable contact lenses (Chapter 10), as reviewed in Table 11-2. Contact lenses with reverse geometry ${ }^{14}$ will center on the decentered flat zone and will be decentered to the line of sight, which duplicate the complexity of optical performance. Using the keratometric values on the transition zone, $0.2-\mathrm{mm}$ peripheral the border of the refractive ablation zone for the selection of the back optic zone radius of the contact lens gave a maximum of comfort to the patient. This in combination with large diameter lenses provided good centration and excellent stability on the cornea.

Post corneal surgery patients present a challenge to the eye care specialist. For this reason, the fitting techniques are described step by step: in Table 11-1 (post keratoplasty contact lens fitting), and in Table 11-2 (contact lens fitting after corneal refractive surgery). 


\section{General discussion}

\section{1-2 REFERENCES}

\footnotetext{
${ }^{1}$ Donnenfeld ED, Kornstein HS, Amin A, Speaker MD, Seedor JA, Sforza PD, Landrio LM, Perry HD. Laser in situ keratomileusis for the correction of myopia and astigmatism after penetrating keratoplasty. Ophthamology 1999;106:1966-74.

${ }^{2}$ Webber SK, Lawless MA, Sutton GL, Rogers CM. LASIK for post penetrating keratoplasty astigmatism and myopia. Br J Ophthalmol 1999;83:1013-8.

${ }^{3}$ Chou AC, Swinger CA, Coger SK. Fitting contact lenses after myopic keratomileusis. J Cataract Refract Surg 1999;25:508-13

${ }^{4}$ Stulting RD, Carr JD, Thopmpson KP, et al. Complications of laser in situ keratomileusis for the correction of myopia. Ophthalmology 1999;106:447-57.

${ }^{5} \mathrm{Knorz} \mathrm{MC}$, Jendritza B. Topographical-guided laser in situ keratomileusis to treat corneal irregularities. Ophthalmology 2000;107:1 138-43.

${ }^{6}$ Wiesinger-Jendritza B, Knorz MC, Hugger P, Liermann A. Laser in situ keratomileusis assisted by corneal topography. J Cataract Refract Surg 1998;24:166-74.

${ }^{7}$ Seiler $\mathrm{T}$. Iatrogenic keratectasia after laser in situ keratomileusis. J Refract Surg 1998;14:312-7.

${ }^{8}$ Speicher L, Göttinger W. Progressive Keratektasie nach Laser-in-situ Keratomileusis (LASIK). Klin Monatsbl Augenheilk 1998;213:247-51

${ }^{9}$ Amoils SP, Deist MB, Gous P, Amoils PM. Iatrogenic keratectasia after laser in situ keratomileusis for less than -4.0 to -7.0 diopters of myopia. J Cataract Refract Surg $2000 ; 26: 967-77$.

${ }^{10}$ Edrington TB, Szczotka LB, Barr JT. Rigid contact lens fitting relationschips in keratoconus. Collaborative Longitudinal Evaluation of Keratoconus (CLEC) Study Group. Optom Vis Sci 1999;76:692-9.

${ }^{11}$ Edrington TB, Barr JT, Zadnik K. Standardized rigid contact lens fitting protocol for keratoconus. Optom Vis Sci 1996;73:369-75.

${ }^{12}$ Demirbas NH, Pflugfelder SC. Topographic pattern and apex location of keratoconus on elevation topographical maps. Cornea 1998;17:476-84.

${ }^{13}$ Reinstein DZ, Silverman RH, Sutton HFS, Coleman DJ. Very high-frequency ultrasound corneal analysis identifies anatomic correlates of optical complications of lamellar refractive surgery; anatomic diagnosis in lamellar surgery. Ophthalmology 1999;106:474-82.

${ }^{14} \mathrm{Lim} \mathrm{L}$, Siow KL, Sakamoto R, Chong JSC, Tan DTH. Reverse geometry contact lens wear after photorefractive keratectomy, radial keratotomy or penetrating keratoplasty. Cornea $2000 ; 19: 320-4$
} 
Chapter 11 


\section{SUMMARY - SAMENVATTING}




\section{$12-1$ Summary}

Therapeutic or refractive comeal surgical procedures may be complicated by high or irregular astigmatism, or anisometropia. Although these complications can sometimes be managed by secondary surgical intervention, most cases are difficult to treat, and may be the only way of correction rigid contact lens fitting. In this thesis, advanced rigid contact lens fitting techniques are described to improve the visual performance following penetrating and lamellar keratoplasty, as well as following various refractive corneal surgical procedures.

('hapter 2 discusses refractive anomalies, corneal refractive surgical techniques, various keratoplasty procedures, and the routine fitting methods of rigid gas permeable contact lenses. (hapter 3 evaluates the efficacy of contact lens fitting three months after penetrating keratoplasty. A new fitting technique is presented, using the corneal topographical ring- and color maps over the wound edges for selection of the contact lens back optic zone radius. Chapter 4 evaluates the same contact lens fitting technique following deep lamellar keratoplasty.

(hapter 5 assesses the efficacy of a new contact lens fitting technique after phototherapeutic keratectomy for granular dystrophy. A comparison of the topographic maps 1 -week and 4 months after surgery demonstrated a change in the surface profile suggesting that epithelial and or stromal hyperplasia had modified the refractive power of the cornea. Since lens movement changes with central corneal curvature changes, contact lens alignment was based on the midperipheral corneal keratometer readings. Choosing a flat base curve and progressive eccentricity toward the periphery prevented lens binding. Chapter 6 evaluates the recovery of visual acuity in a family with Reis Bückler dystrophy, following phototherapeutic keratectomy. Phototherapeutic keratectomy rendered such smooth corneal surfaces that best spectacle corrected visual acuity could not be improved with rigid gas permeable contact lenses.

In Chapter 7, it is described that after photorefractive keratectomy with a $5.0 \mathrm{~mm}$ aperture, optical zone enlargement techniques may be more effective to improve the visual acuity, than contact lens fitting. (hapter 8 evaluates the visual recovery after laser in situ keratomileusis (LASIK) complication by flap loss. In one patient visual recovery could only be obtained with the fitting of a rigid gas permeable contact lens. Two patients did not need contact lenses for visual recovery. (hapter 9 describes the first rigid gas permeable contact lens fitting technique to improve visual acuity in a patient with keratectasia following LASIK. Chapter 10 describes another unique technique for contact lens fitting and evaluates the efficacy of this fitting technique after multifocal ablation patterns to correct ghost images and impaired night vision. 
Contact lens fitting following corneal surgery is challenging. However, rigid gas permeable contact lenses may be a safe and efficacious treatment in selected patients for the management of post-operative multifocality of the cornea, high irregular astigmatism and anisometropia. include:

The fitting techniques in surgically altered corneas described in this thesis,

- the use of an total contact lens diameter of at least 11.0 millimeters to avoid lens instability and decentration

- the use of the elevated circular transplant wound as the bearing zone following keratoplasty surgery

- the use of trial lenses with back optic zone diameter of 8.5 millimeters

- alignment on the mid-peripheral part of the cornea

- maintenance of good lens clearance in the periphery

- use high Dk contact lens material.

\section{$12-2$ Samenvatting}

Zowel na hoornvliestransplantatie als na cornea refractie chirurgie, kunnen hoog- of irregulair astigmatisme alsmede anisometropie de visuele resultaten nadelig beïnvloeden. Genoemde complicaties kunnen soms met een tweede chirurgische ingreep worden verholpen, maar zijn in de meeste gevallen operatief moeilijk te behandelen. Hierbij biedt het aanmeten van vormvaste zuurstofdoorlatende contactlenzen een uitkomst. In dit proefschrift worden geavanceerde contactlens aanmeettechnieken beschreven. De vormvaste zuurstofdoorlatende contactlenzen verbeteren het zien bij patiënten na een perforerende- en lamellaire hoomvliestransplantatie, alsmede na verschillende vormen van corneale refractie chirurgie.

Hoofdstuk 2 gaat uitgebreid in op de brekingsfouten van het oog, de excimer laser chirurgie alsmede de huidige en nieuwe hoornvliestransplantatie technieken en de techniek van het aanmeten van vormvaste zuurstofdoorlatende contactlenzen. Hoofdstuk 3 beschrijft en evalueert de resultaten van een nieuwe techniek om zuurstofdoorlatende vormvaste contactlenzen aan te meten bij patiënten die drie maanden voorafgaand een perforerende hoornvliestransplantatie hebben ondergaan. Door gebruik te maken van de cornea topografie, zowel de ring map als het kleuren plaatje, wordt het makkelijker om kromming ter plaatse van de gezwollen wondranden te meten welke de basis curve radius van de contactlens te bepalen, hetgeen uniek is in de literatuur. Hoofdstuk + beschrijft dezelfde nieuwe contactlens aanmeet techniek en evalueert de resultaten na een diep lamellaire hoornvliestransplantatie. 
In Hoofdstuk 5 worden de resultaten van vormvaste zuurstofdoorlatende contactlenzen bij een granulaire dystrofie na phototherapeutic keratectomie (PTK) geëvalueerd. Een vergelijking van de cornea topografie één week en vier maanden na de operatie laat zien dat gedurende deze periode veranderingen aan het cornea oppervlak plaats vinden. Vermoedelijk door epitheliale- of stromale hyperplasie wordt de refractieve breking van de cornea positief beïnvloed. De keuze van de basis curve radius van de contactlens is gebaseerd op het niet veranderde perifere gedeelte van de cornea. De contact lens heeft een naar de periferie toe progressieve excentriciteit waardoor deze niet vast gaat zitten.

Hoofdstuk 6 evalueert het herstel van de gezichtsscherpte in een familie met een Reis Bückler dystrofie, zes maanden na PTK. De PTK techniek is zo verfijnd dat de postoperatieve gezichtsscherpte zes maanden na de operatie met bril gelijk is aan de gezichtsscherpte met een vormvaste zuurstofdoorlatende contactlens.

In Hoofdstuk 7 wordt een techniek beschreven om de optische zone van een photo refractive keratectomy excimer laser behandeling van $5.0 \mathrm{~mm}$ te vergroten tot $6.0 \mathrm{~mm}$. De techniek om de optische zone met de laser te vergoten is eleganter en vermoedelijk net zo effectief als het aanmeten van contactlenzen bij deze patiënten. Hoofdstuk 8 evalueert het herstel van de gezichtsscherpte bij laser in situ keratomileusis (LASIK) patiënten die hun flap verloren hebben, één week na een LASIK operatie. Bij één van deze patiënten kon de gezichtsscherpte uitsluitend met behulp van een vormvaste zuurstofdoorlatende contactlens worden hersteld. Twee patiënten maakten een spontaan herstel van de gezichtsscherpte door. In hoofdstuk 9 wordt voor het eerst een techniek beschreven om bij een patiënt die een keratectasia na LASIK behandeling heeft ontwikkeld, een vormvaste zuurstofdoorlatende contactlens aan te meten om zo de gezichtsscherpte te herstellen. In hoofdstuk 10 wordt een unieke techniek beschreven waarbij een vormvaste zuurstofdoorlatende contactlens wordt aangemeten bij patiënten met een multifocale cornea na LASIK, om schaduw beelden en onvoldoende zien in het donker te corrigeren. Tevens worden de resultaten hiervan geëvalueerd.

Mede door de veranderde vorm van de cornea is het bijzonder uitdagend om contactlenzen aan te meten na cornea chirurgie. Zuurstofdoorlatende vormvaste contactlenzen lijken hierbij het meest effectief en veilig bij de behandeling van geselecteerde patiënten met een multifocale cornea, hoog- en irregulair astigmatisme alsmede om anisometropie te corrigeren.

$\mathrm{Bij}$ de in dit proefschrift beschreven technieken om vormvaste zuurstofdoorlatende contactlenzen na cornea chirurgie aan te meten is gebruik gemaakt van: grote contactlens diameters van minimaal 11,0 millimeter waardoor instabiliteit- en decentratie van de lens wordt voorkomen; de verheven wondranden bij transplantatie patiënten en de transitie of niet veranderde 
perifere zones na excimer laser chirurgie hebben wij als draagvlak voor de contactlens laten fungeren; de diameter van de optische zone van de contactlens was altijd groot om zodoende dit draagvlak te kunnen benutten; de periferie van de contactlens hebben wij goed van de cornea laten af staan waardoor voldoende traanuitwisseling onder de lens plaats kon vinden, tevens hebben wij in alle contact lens aanpassingen gebruik gemaakt van een zeer hoog zuurstofdoorlatend contactlens materiaal. 
List of abbreviations

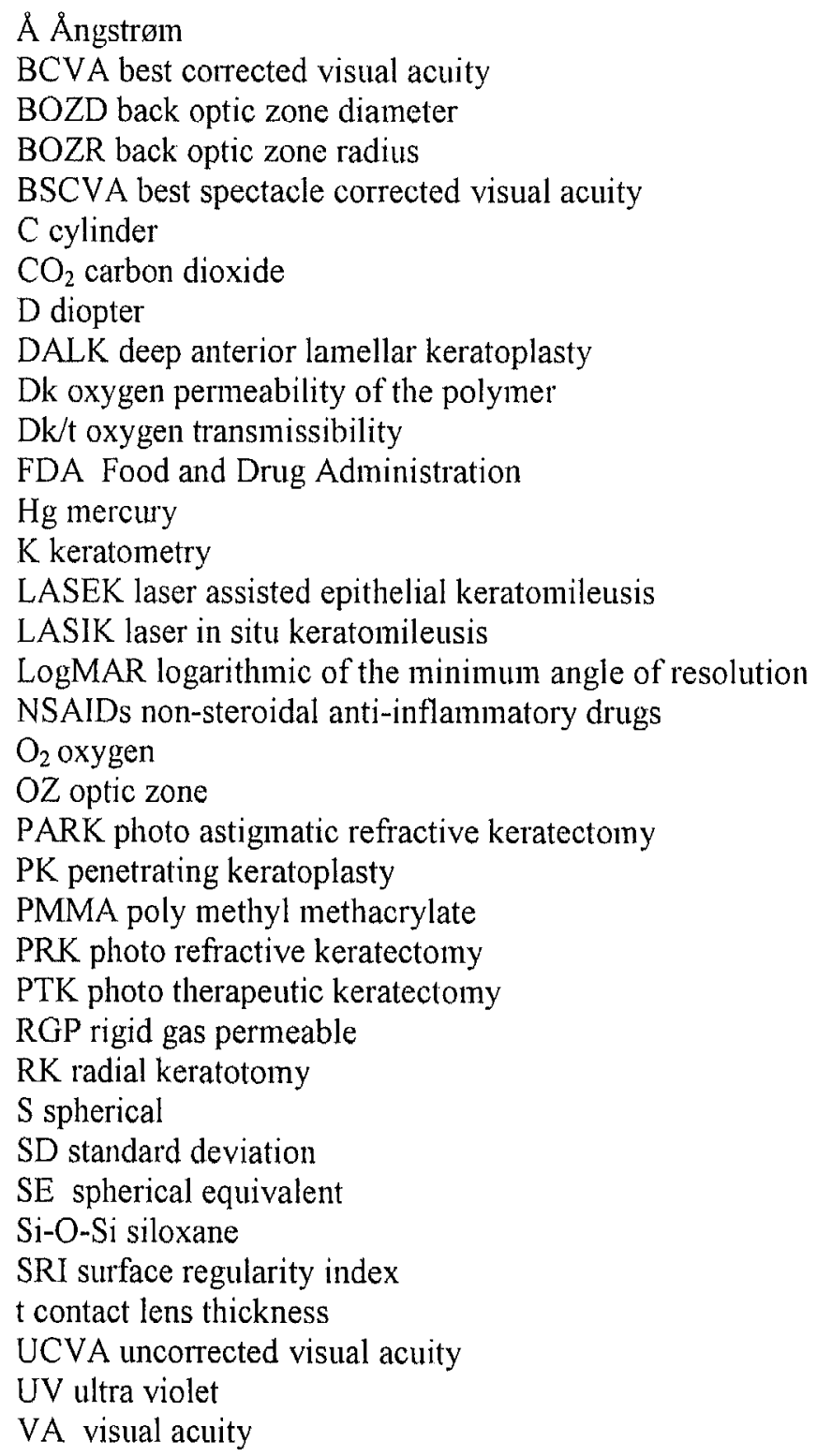




\section{List of publications}

- Pinckers A, Eggink F, Aandekerk A, van 't Pad Bosch A. Contact lens-induced pseudo-dystrophy of the cornea? Documenta Ophthalmol 1987;65:433-437.

- Eggink FAGJ. De stand van zaken bij de refractieve chirurgie. Oculus 1987;(1)31-34.

- Eggink FAGJ, Pinckers AJLG, van Puyenbroek EP, Theeuwes A. Keratoconus a retrospective study. Contact Lens J 1988;16(8):204-206.

- Eggink FAGJ. Bifocaal contactlenzen, een overzicht. Visus 1988;(1)12-13

- Eggink FAGJ, Pinckers AJLG. Problems with siloxanyl-alkyl-methaylacrylate and fluoro silicon acrylate contact lens materials. Contactologia 1988:10:169-171

- Pinckers A, Aandekerk AL, Renardel de Lavalette V, Eggink F. Contact lens induced severe epithelial disruption. International Ophthalmology 1989;13:229-232

- Eggink FAGJ, Pinckers AJLG. Observations in High Water Content MMA/VP Copolymer contact lenses. The Contact Lens J 1989;17:40-43.

- Eggink FAGJ, Beekhuis WH. Contact lens fitting following radial keratotomy and other relaxing incisions of the cornea. Contactologia 1989;11:164-168.

- Eggink FAGJ, Pinckers AJLG. Keratoconus. Visus 1989;(2);6-12

- Ververs B, Beekhuis WH, Vreugdenhil W, Eggink FAGJ. The Disposable Acuvue Contact Lense; a pilot study in the Netherlands. Contactologia 1989;11:168-172.

- Eggink FAGJ, Pinckers AJLG, de Graaf R. Visual acuity and contrast sensitivity with Diffrax contact lenses. The Contact Lens J 1990;18(2);37-39

- Vreugdenhil W, Eggink FAGJ, Beekhuis WH. Changes in corneal thickness under four different rigid gas permeable contact lenses for daily wear. Optom and Vis Sci 1990;67:670-672.

- Eggink F, Vreugdenhil W. Eerste ervaringen met het nieuwe Boston RXD contactlens materiaal Oculus 1991;52(4):31-33

- Beekhuis WH, van Rij G, Eggink FAGJ, Vreugdenhil W, Schoevaart CE Contact Lenses Following Keratoplasty. CLAO J 1991;17(1):27-29. 


\section{Publications}

- Eggink FAGJ, Pinckers AJG. Vorauswahl von Patienten fur die Anpassung von Kontaktlinsen. Die Contactlinse 1991;4:20-21.

- Eggink FAGJ, Pinckers AJLG, Aandekerk AL. Subepithelial Opacities in Daily Wear High Water Content Soft Contact Lenses. Contacologia 1991;13(4): 173-176.

- Eggink FAGJ, Beekhuis WH, Vreugdenhil W. Keratoplastiek en contactlenzen. Visus 1991;4:1115

- Eggink FAGJ, Revival of the photokeratoscope. The J of the Br Contact Lens Ass $1992 ; 15 ; 51$.

- Eggink FAGJ, Pinckers AJLG, Beekhuis WH, Vreugdenhil W. Conserveermiddelen in contactlensvloeistoffen en hun bijwerkingen. Visus 1992;5(2):26-31.

- Eggink FAGJ, Beekhuis WH. La kératectomie photoréfractive. Optomagazine 1992;2:7-11

- Beekhuis WH, Eggink FAGJ, Vreugdenhil W, Platenkamp GJ, Buitenwerf J. Disinfection of trial mid water content soft contact lenses in the practice: The efficacy of sodium dichloroisocyanurate The J of the Br Contact Lens Ass 1992;15:103-107.

- Vreugdenhil W, Eggink FAGJ, Beekhuis WH. Is there an Indication for fitting High Dk RGPlenses in former PMMA Wearers? Contactologia 1992;14:133-136.

- Eggink FAGJ. La kératectomie photoréfractive. L'opticien lunetier 1992;461:71-74

- Ramselaar JAM, Polak BCP, Beekhuis WH, Eggink FAGJ. Preservatives in ophthalmic solutions, ontments and contact lens solutions. J for drugtherapy and research 1992;17(9):205-207.

- Eggink FAGJ. Considérations sur la fonction, le métabolisme et la liaison entre les couches de l'épithélium antérieur, ainsi que le rôle du film lacrymal. Optomagazine 1993;(1):20-29.

- Eggink FAGJ, Vreugdenhil W, Beekhuis WH. Do we need high Dk RGP lenses for daily wear? The Contact Lens J 1993;21(3):6-9.

- Eggink FAGJ, Pinckers AJLG, de Graaf R. Two soft concentric varifocal lenses. Contactologia $1993 ; 15: 26-29$

- Odenthal MThP, Eggink FAGJ, Vreugdenhil W, Beekhuis WH. Corneal response to Quantum II Rigid Gas Permeable Extended Wear Lenses. Contactologia 1993;15:30-34.

- Beekhuis H, Talsma M, Vreugdenhil W, Eggink F, Peperkamp E, van Meurs J Changes in refraction after retinal detachment surgery corrected by contact lenses for early visual rehabilitation. Retina 1993;13:120-124. 
- Eggink FAGJ, Vreugdenhil W, Beekhuis WH. Therapeutische Kontaktlinsen nach Keratoplastiek die Kontaktiinse 1994;28(1/2):5-10.

- Eggink FAGJ. Un anee apres le introduction de Excimer Laser a Rotterdam. Optomagazine 1994; (1): 18-23.

- Vreugdenhil W, Rijneveld WJ, Eggink FAGJ. Fitting therapeutic SoftPerm contact lenses in the event of corneal pathology with highly irregular astigmatism. The $\mathrm{J}$ of the $\mathrm{Br}$ contact lens ass 1994;17(2):59-61

- Eggink FAGJ, Beekhuis WH. Granular dystrophy of the cornea. Contact lens fitting after Phototherapeutic Keratectomy. Cornea 1995;14(2):217-222.

- Eggink FAGJ, Beekhuis WH, Trokel S, den Boon JM. Enlargement of the optical zone combined with retreatment of undercorrections after photorefractive keratectomy. Investigative Ophthal \& Vis Sci 1995;36(4):3292.

- Eggink FAGJ, Beekhuis WH, Tilburg CJ van. Excimer laser één jaar follow-up. Oculus oktober 1995 .

- Eggink Fred, Beekhuis Houdijn. Enlargement of the optical zone diameter in excimer PRK patients. Investigative Ophthal \& Vis Sci 1995;72(12):124 (supp)

- Eggink FAGJ, Beekhuis WH, Geerards AJM, Schmit C, Katlun T, Binder PS. Potential cause for Undercorrections Following Excimer Laser PRK. Investigative Ophthal \& Vis Sci 1996; $37(3):$ s239.

- Eggink FAGJ, Beekhuis WH, Trokel SL, den Boon JM. Enlargement of the photorefractive keratectomy optical zone. J Cataract Refraci Surg 1996:22:1159-1164.

- Eggink FAGJ, Melles GJ, Eggink CE, Beekhuis WH, Binder PS. Double-punch keratoplasty in a kat model. Investigative Ophthal \& Vis Sci 1997;38(4):s860

- Eggink Fred A, Cees J. van Tilburg, Annette J. Geerards, Bob Ververs, W.Houdijn Beekhuis Correction of myopia and astigmatism using (PARK) scanning beam technology. Investigative Ophthal \& Vis Sci 1998;38(4): 3.346

- Nuyts RM, Mulder LJ, Eggink FA. Clinical and ultrastructural characteristics of human corneas after radial keratotomy. Investigative Ophthal \& Vis Sci 1998;38(4):s354.

- Melles GRJ, Eggink FAGJ, Lander F, Pels E, Rietveld FJR, Beekhuis WH, Binder PS. A Surgical Technique for Posterior Lamellar Keratoplasty. Cornea 1998;17(6):618-626

- Melles GJ, Eggink FAGJ. Topography Following Keratoplasty in Cats is not Representative of That in Humans. J Refractive Surg. 1999;15(1):74-75. 
- Eggink FA, Melles GR, Lander F, Geerards AJ, Remeijer L, Beekhuis WH. Preliminary Results of the Rotterdam Technique for Deep Anterior Lamellar Keratoplasty. Investigative Ophthal \& Vis Sci 1999;39(4):s632

- Eggink FAGJ, Beekhuis WH. Contact lens fitting in a patient with keratectasia following laser in situ keratomileusis. J Cataract Refract Surg 200 I;27:1119-23

- Eggink FAGJ, Nuijts RMMA. A new technique for fitting rigid gas permeable contact lenses following penetrating keratoplasty. Acta Ophthalmol Scand 2001;79:245-50

- Eggink FAGJ, Eggink CA, Beekhuis WH. Postoperative management and follow up after corneal flap loss following laser in situ keratomileusis. J Cataract Refract Surg 2001;27:

- Eggink FAGJ, Nuijts RMMA, Beekhuis WH. Rigid gas permeable contact lens fitting in LASIK patients for the correction of multifocal corneas. Graefe's Arch Clin Exp Ophthalmol $2001,239: 361-6$

- Eggink FAGJ. Techniques to improve visual performance following corneal surgery. Thesis 2001 


\section{Dankwoord.}

Graag wil ik iedereen die een vooraanstaande rol heeft gespeeld bij mijn opleiding tot het huidige niveau en het tot stand komen van mijn proefschrift bedanken. Het publiceren is lang geleden begonnen met een artikel dat ik samen met Houdijn Beekhuis heb geschreven. Er waren destijds nog geen tekstverwerkers. Veel, zoniet alles wat ik nu weet over de cornea heeft Houdijn mij bijgebracht daarvoor ben ik hem veel dank verschuldigd. Houdijn en ik werken al tientallen jaren samen, hebben samen veel beleefd en gepubliceerd. Ook samen met Fred Pinckers heb ik meerdere publicaties geschreven. Hij was een begenadigd wetenschapper. Gerrit Melles had een mannetje nodig die hem assisteerde bij dierproeven. Daar wilde ik graag bij zijn, wij hebben samen veel geleerd, heel veel lol gehad maar ook ontelbare uren serieus zitten praten en uiteraard gepubliceerd. Rudy Nuijts was de eerste die mij vroeg of ik er iets voor voelde om te promoveren. Hij heeft mij ertoe overgehaald nog zes publicaties te schrijven om een "samenhangend" proefschrift op te kunnen zetten.

Mijn promotor professor dr. F. Hendrikse heeft mij, na de tijd die we samen in Nijmegen hebben doorgebracht, naar Maastricht gehaald en samen met Rudy de plannen verder gesmeed om mij het vertrouwen te gunnen om mijn promotie tot een goed einde te brengen.

Mijn copromotoren Rudy en Gerrit hebben de laatste twee jaar allebei hun handen vol gehad aan mijn schrijverij en zullen regelmatig gedacht hebben "daar heb je weer zo'n stapel werk om door te lezen en te corrigeren". Ik wil jullie hartelijk danken voor de stimulerende gesprekken die wij in de loop van de afgelopen jaren aangaande het verloop en de uiteindelijke afronding van dit promotieonderzoek hebben gehad. Tevens bedank ik jullie voor de aanmoedigende en stimulerende begeleiding tijdens de afrondingsfase en de lange doorwaakte uren samen. $\mathrm{lk}$ hoop nog vele jaren met jullie te mogen samen werken.

De leden van de beoordelingscommissie Prof. dr. ir. L.H. Koole (voorzitter), Prof. dr. ir. A.P.G. Hoeks, dr. C.A.B. Webers, Prof. dr. A.F. Deutman en Prof. dr. G. van Rij dank ik voor het beoordelen van het manuscript.

Met alle medeauteurs, Houdijn Beekhuis, Rudy Nuijts, Gerrit Melles, Annette Geeraerts, Willem Vreugdenhil, Cathrien Eggink, Marius den Boon en Stephen Trokel, heb ik stimulerende contacten gehad welke hebben geleid tot deze acht publicaties. Tevens dank ik mijn collegae, stafartsen, polimedewerkers, fotografe Marion Machiels en verpleegkundigen van de afdeling oogheelkunde van het azM Maastricht, en de collegae, stafartsen, directie, fotografen Bert Sinit en Cees van Oostende en verpleegkundigen van Het Oogziekenhuis Rotterdam. I would also like to thank dr Patti Fuhr for her patience in editing Chapter 2 from the manuscript. 
Achter elke hard werkende man of vrouw staat een succesvolle partner. Lieve Lya, ik heb dit proefschrift aan jou opgedragen omdat jij mijn grootste supporter bent en al jouw aanmoedigingen, vooral in het laatste jaar, mij enorm tot steun zijn geweest. 


\section{Curriculum vitae.}

Ferdinand Antonius Gerardus Johannes Eggink werd geboren op 29 maart 1948 te 's-Gravenhage. Na zijn middelbare school behaalde hij aan de Christiaan Huygensschool te Rotterdam de diploma's voor Opticien, Oogmeetkundige en Contactlensspecialist. In 1977 behaalde hij zijn tweede graad lesbevoegdheid bij het Nederlands Genootschap tot Opleiding van Leraren voor het Beroepsonderwijs te 's-Gravenhage.

Als contactlensspecialist bij Oculenti is hij sinds 1977 werkzaam aan de afdeling oogheelkunde van het Universitair Medisch Centrum St. Radboud te Nijmegen (Prof. dr. A.F. Deutman) en sinds 1992 eveneens aan de afdeling oogheelkunde van het academisch ziekenhuis Maastricht (Prof. dr. F. Hendrikse).

Als oogmeetkundige is hij sinds 1992 tevens verbonden aan het Centrum voor Refractie Chirurgie van Het Oogziekenhuis Rotterdam en sinds 2001 aan het Academisch Centrum voor Refractie Chirurgie van het academisch ziekenhuis Maastricht.

Sinds 1995 is hij Fellow of the American Academy of Optometry.

Hij is gelukkig getrouwd met Lya Houtman en zij hebben samen twee kinderen, Joep (27) en Mirjam (25). 